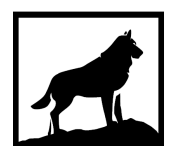

Michigan Technological

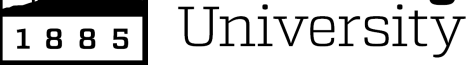

Michigan Technological University Digital Commons @ Michigan Tech

2016

EFFECTS OF WILDFIRE AND POST-FIRE SALVAGE LOGGING ON RILL NETWORKS AND SEDIMENT DELIVERY IN CALIFORNIA FORESTS

Will Olsen

Michigan Technological University, wolsen@mtu.edu

Copyright 2016 Will Olsen

Recommended Citation

Olsen, Will, "EFFECTS OF WILDFIRE AND POST-FIRE SALVAGE LOGGING ON RILL NETWORKS AND SEDIMENT DELIVERY IN CALIFORNIA FORESTS", Open Access Master's Thesis, Michigan Technological University, 2016.

https://doi.org/10.37099/mtu.dc.etdr/287

Follow this and additional works at: https://digitalcommons.mtu.edu/etdr

Part of the Forest Management Commons, Hydrology Commons, and the Soil Science Commons 


\title{
EFFECTS OF WILDFIRE AND POST-FIRE SALVAGE LOGGING ON RILL NETWORKS AND SEDIMENT DELIVERY IN CALIFORNIA FORESTS
}

By

Will H. Olsen

\begin{abstract}
A THESIS
Submitted in partial fulfillment of the requirements for the degree of MASTER OF SCIENCE

In Applied Ecology
\end{abstract}

MICHIGAN TECHNOLOGICAL UNIVERSITY

2016

(C) 2016 Will H. Olsen 
This thesis has been approved in partial fulfillment of the requirements for the Degree of MASTER OF SCIENCE in Applied Ecology.

School of Forest Resources and Environmental Science

Thesis Advisor: Joseph W. Wagenbrenner

Committee Member: $\quad$ Peter R. Robichaud

Committee Member: Casey J. Huckins

School Dean: Terry L. Sharik. 


\section{Table of Contents}

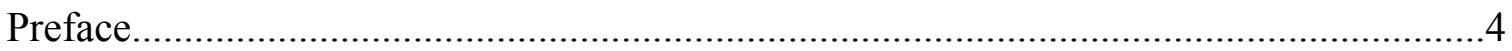

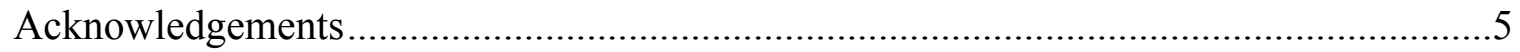

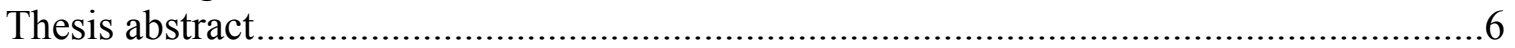

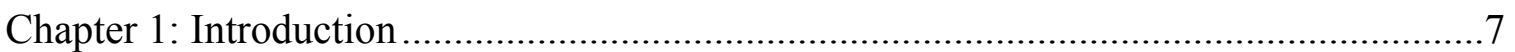

Chapter 2: The effect of burn severity on rill network formation and sediment yield in the

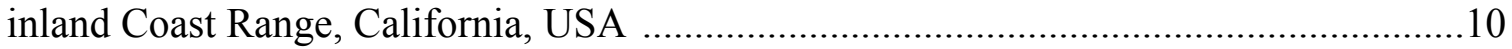

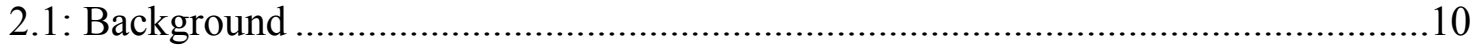

2.2: Site description ......................................................................................11

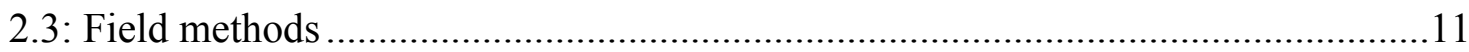

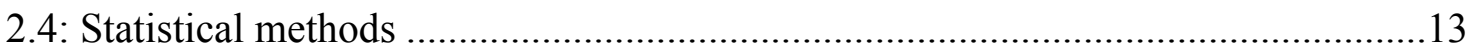

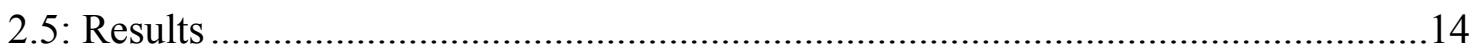

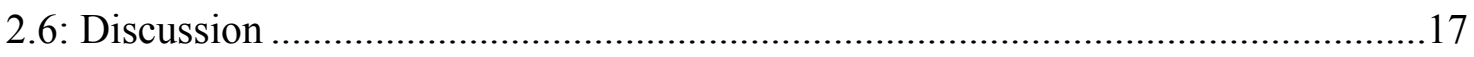

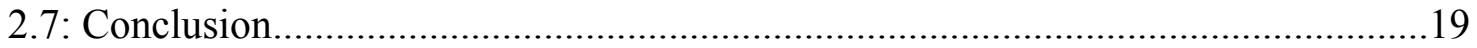

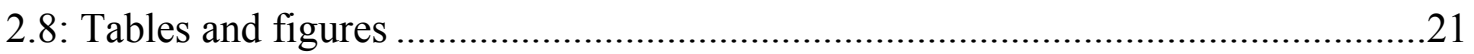

Chapter 3: Effect of post-fire salvage logging on rill network formation and sediment

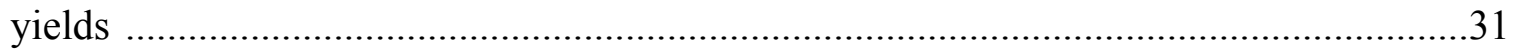

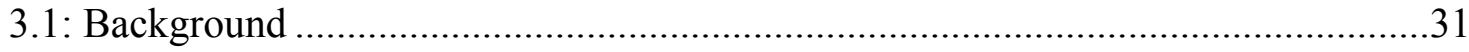

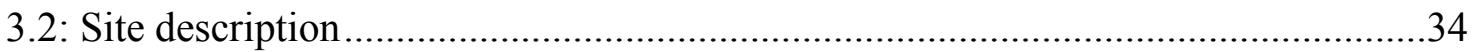

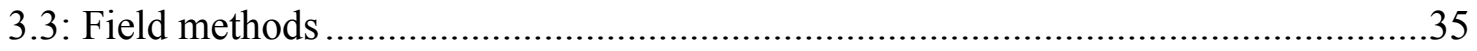

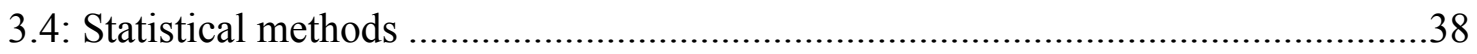

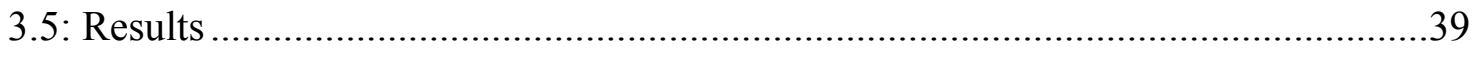

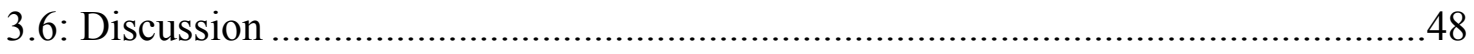

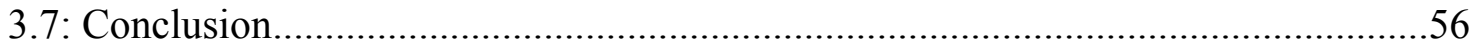

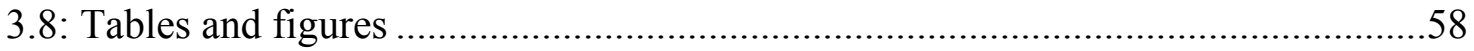

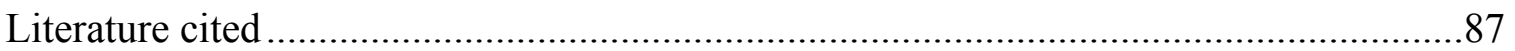

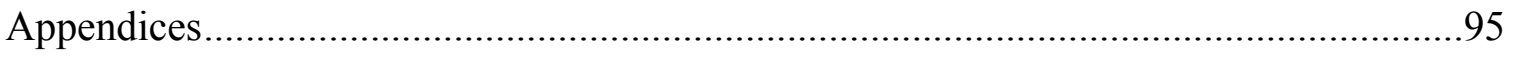




\section{$\underline{\text { Preface }}$}

Chapter 2: Effect of burn severity on rill network formation and sediment yield in the inland Coast Range, California, USA

Research and field data gathering were done in collaboration with Drew Coe and Don Lindsay of the California Department of Forestry and Fire Protection and Joe Wagenbrenner of Michigan Tech and the USDA Forest Service, with the exception of rill measurements that were made by Will Olsen. Research questions and data analysis were developed by Will Olsen with assistance from Joe Wagenbrenner.

Chapter 3: Effect of post-fire salvage logging on rill network formation and sediment yields

Research and field data were gathered in collaboration with the USDA Forest Service Rocky Mountain Research Station (Moscow, ID), USDA Forest Service Pacific Southwest Research Station (Riverside, CA), Joe Wagenbrenner and Iskender Demirtas (Michigan Tech). Research questions, data analysis, and writing were developed by Will Olsen with assistance from Joe Wagenbrenner.

Chapter 2 and 3 will both be prepared and submitted to a peer-reviewed journal at a future time. 


\section{Acknowledgements}

I'd like to first acknowledge and thank the USDA Forest Service Rocky Mountain Research Station and Pacific Southwest Research Station for the funding they provided for research on the Rim Fire. I would also like to thank the International Association of Wildland Fire for additional funding that supported both research on the Rim Fire and Valley Fire at Boggs Mountain Demonstration State Forest.

The following thesis is a product of many individuals time, energy, help and input. I would like to thank the researchers, field assistants, and volunteers of the USDA Rocky Mountain Research Station (Moscow, ID) and Pacific Southwest Research Station (Riverside, CA). I'd also like to thank the staff with the California Department of Forestry and Fire Protection, California Geological Survey, and at Boggs Mountain Demonstration State Forest, CA, for their help and insight, including assistance from Drew Coe.

Dr. Pete Robichaud, in addition to serving on my committee, gave valuable insight and help in understanding post-fire processes and management questions, along with a laugh or two. Bob Brown and Sierra Larson of the Rocky Mountain Research Station provided an immense amount of invaluable help in the field and laboratory.

Ashlee Baker, Tommy McDade, Iskender Demirtas and Liz Ernst of Michigan Technological University assisted with countless hours of fence construction, cleanouts, and data gathering. Troy Hensiek made the trip to California several times to spend many hours helping with bulk density sampling and fence construction in the field. Scott Cereghino and Nate Ashmead are owed an especial thanks for the tons of sediment they helped dig out each winter from the Rim Fire fences.

Thanks are in order to the Stanislaus National Forest for allowing us to research post-fire salvage logging within the forest, and the timber sale administrators for their assistance. Tracy Weddle and Curtis Kvamme deserve a very big thank you for serving as both liaisons to the Stanislaus National Forest, and their help throughout the project, including answering my endless questions about best management practices.

To my committee, for their commitment, time, and energy in making this research come to fruition, are owed many thanks, I owe many thanks.

Lastly, I owe a debt of gratitude to Joe Wagenbrenner for an extremely unique and incredible opportunity to work in a field I had little knowledge about initially. The countless hours of assistance in the field, classroom, and writing this thesis are beyond thanks, in addition to teaching me how to be a scientist and researcher. 


\section{Thesis Abstract}

Wildfires can increase soil erosion by orders of magnitude over rates in unburned forests and negatively impact aquatic resources. Rill erosion is a dominant erosion and sediment transport mechanism in burned forests, and hydrologically connected rills can form networks on burned hillslopes. At the swale scale $\left(<10,000 \mathrm{~m}^{2}\right)$, little is known about how rill networks develop under different burn severities over time, their relationship with sediment yields, and the effect of post-fire salvage logging on rill networks and sediment yields.

The first study assessed rill networks and sediment yields in three burn severities in the inland Coast Range of California, USA, after the 2015 Valley Fire. The results indicated the rill networks in high burn severity areas reached nearly the entire extent of the burned hillslopes. Rill densities in high burn severity areas were significantly higher $\left(19-23 \mathrm{~cm} \mathrm{~m}^{-2}\right)$ than low and moderate severity areas $\left(0.5-2.1 \mathrm{~cm} \mathrm{~m}^{-2}\right)$. Sediment yields from high burn severity areas (13-15 $\left.\mathrm{Mg} \mathrm{ha}^{-1}\right)$ were significantly higher than the low to moderate burn severity areas $\left(0.1-3.4 \mathrm{Mg} \mathrm{ha}^{-1}\right)$, and highly correlated with rill density $\left(\mathrm{r}^{2}\right.$ $=0.97)$. Results indicate that the extensive rill networks in high burn severity areas can greatly increase connectivity, resulting in increased sediment delivery downslope.

The second study assessed the effects of post-fire salvage logging on soil bulk density, field saturated hydraulic conductivity, ground cover, rill networks and sediment yields in the central California Sierra Nevada following the 2013 Rim Fire. Post-fire logging resulted in $9-56 \%$ percent soil disturbance, which was dominated by high traffic skid trails $(9-29 \%)$. Feller buncher tracks averaged $2 \%$ of swale areas, while mixed traffic areas averaged $7 \%$ and were only found in five of nine logged swales. Within high traffic logging disturbance soil bulk density was increased, field saturated hydraulic conductivity reduced, and bare soil increased. When scaled up to the swale scale, logging had no significant effect on ground cover, but did result in significantly higher wood cover relative to unlogged swales. High traffic skid trails typically initiated extensive rill networks, with up to $20 \mathrm{~cm} \mathrm{~m}^{-2}$ sourced from skid trails. Rills in skid trails were typically concentrated at waterbars and directed downslope, where they often connected to the outlet. Control swales had 4-18 rills from untrafficked areas, and logged swales had 0-15 rills from untrafficked areas and 1-12 rills from disturbed areas. As with the ground cover, rill densities in logged and unlogged swales were not significantly different. Mean annual sediment yields in logged and unlogged swales were not significantly different, and the high input of wood cover from logging did not have a significant effect on rill density or sediment yield. In unlogged and logged swales, both rill density and sediment yield appeared to be reduced by large areas of undisturbed ground with high surface roughness, which disconnected rills from the stream network. To reduce rill connectivity and sediment delivery from logging disturbance, land managers should optimize skid trail layouts to reduce the spatial footprint of skid trails, increase ground cover on skid trails and below waterbar outlets, and retain buffers with high ground cover between logging disturbance and ephemeral channels. 


\section{Chapter 1: Introduction}

In the western United States historic forest management and fire suppression, in conjunction with a changing climate, have led to increasingly frequent wildfires since the 1980's (Flannigan et al., 2000, Westerling et al., 2006, Littell et al., 2009). Within the forested regions of central and northern California, high fuel loads, extended periods of high temperatures, and decreased precipitation have produced a significant increase in stand-replacing wildfires, with increased estimates for the size and occurrence of future severe wildfires (Fried et al., 2004, Westerling and Bryant, 2008, Miller et al., 2009, Westerling et al., 2011).

Following severe wildfires in forested landscapes, soil water repellency and other changes to soil properties can reduce infiltration rates and increase the rate and frequency of runoff in burned areas (Robichaud, 2000, Martin and Moody, 2001, Robichaud et al., 2016). The loss of ground cover following severe wildfires can be a dominant factor for elevated soil erosion rates at the hillslope scale (Benavides-Solorio and MacDonald, 2001, Larsen et al., 2009, Robichaud et al., 2016). At the catchment and basin scale, runoff and sediment delivery to downstream networks can increase significantly, posing a threat to downstream aquatic resources, particularly after extensive high severity wildfires (Helvey, 1980, Ice et al., 2004, Moody and Martin, 2009, Moody et al., 2013, Stone et al., 2014, Bladon et al., 2014). Increases in wildfire activity and precipitation intensities due to climate change within regions of the western US may lead to detrimental sediment issues within burned mountainous watersheds (Gould et al., 2016).

Rill erosion occurs when overland runoff is concentrated and incision occurs, creating small channels typically several centimeters in depth. Rills transport eroded sediment downslope, and may be persistent features on the landscape. Rill erosion in recently burned forests can be a dominant sediment source and transport mechanism (Pietraszek, 2006, Moody et al., 2013). Robichaud et al. (2010) found sediment flux rates during simulated rill experiments in high burn severity areas were on the same order of magnitude as erosion rates in recently tilled agricultural fields, and significantly higher than erosion rates in undisturbed forests. 
Mitigation techniques to reduce post-fire erosion rates have been shown to have varying levels of effectiveness. Contour barriers such as felled logs, straw wattles, and trenches may reduce erosion rates for smaller rainfall events, but typically fail during larger high intensity rainfall events (Robichaud et al., 2008a, Robichaud et al., 2008b). The application of mulch such as wood strand or wheat straw can reduce erosion and runoff rates significantly (Wagenbrenner et al., 2006, Robichaud et al., 2013a, Robichaud et al., 2013b). The harvest of burned trees or "salvage logging" is another post-fire management tool. Salvage logging is typically undertaken to achieve economic goals in addition to land management goals such as future fuel reduction and reforestation. Postfire salvage logging has also been cited as a tool to reduce post-fire soil erosion, through the breakup of water repellant soil layers by machinery and the increase in ground cover due to logging slash (Poff 1989, McIver and Starr, 2001).

Salvage logging can be a controversial management practice following a wildfire, particularly on public lands. Concerns include the potential loss of landscape scale benefits imparted by the disturbance of wildfires (Lindemayer et al., 2004) and negative impacts to biodiversity and some ecosystem services (Lindenmayer and Noss, 2006). In post-fire salvage logging, removal of large wood from the forest structure can negatively impact bird populations dependent on burned forests (McIver and Starr, 2001, Beschta et al., 2004), and ground based harvesting systems may reduce forest regeneration (Donato et al., 2006). Of special concern is the impact of post-fire salvage logging on aquatic systems and watersheds, in particular when ground based retrieval systems are used. Karr et al. (2004) summarized potential impacts to include damage to recovering soils, increased runoff and sedimentation of rivers and streams, impacts to aquatic species, and the introduction of new road systems in forested areas. Extensive road systems are often needed in order to haul harvested trees from a forest via log trucks, however roads are also significant sediment sources within forests (Luce and Black, 1999, MacDonald et al., 2004). A 2001 review of existing studies on the effects of salvage logging on erosion, McIver and Starr found a wide range of results that indicated logging after fires may increase, decrease, or have no detectable impact on soil erosion. 
The following two studies address gaps in understanding how rill networks evolve under different soil burn severities ("burn severity"), the relationship between rill erosion and sediment yields, how salvage logging affects soil and ground cover properties, and salvage logging effects on the formation of rill networks on burned hillslopes. We studied the effects of wildfire in the inland Coast Range of California, USA, and logging in recently burned areas in the central Sierra Nevada of California, USA. 


\section{Chapter 2: The effect of burn severity on rill network formation and sediment yield in the inland Coast Range, California, USA $^{1}$}

\section{$\underline{2.1 \text { Background }}$}

Changes in vegetation and soil properties following wildfire can act as a significant driver to alter hydrologic aspects of a burned landscape (Shakesby and Doerr, 2006). Wildfire models based on climate change predictions have indicated a significant increase in wildfire size, occurrence, and severity in northern California, including in mixed conifer forests common to the inland Coast Range of California (Fried et al., 2004).

Following high burn severity wildfires, simulated rill experiments indicated that wildfire can elevate the erodibility of forest soils by one to two orders of magnitude relative to unburned forest soils (Wagenbrenner et al., 2010). 60-80\% of sediment yields were accounted for by rill erosion in the Colorado Front Range, with bare soil as a dominant explanatory variable in annual sediment yields (Pietraszek, 2006). Rills have been identified as a fundamental feature in drainage networks on hillslopes following wildfires, with rill networks characterized as either parallel rills draining downslope, or three to six converging rills above a channel head (Moody and Kinner, 2006). On small $16.8 \mathrm{~m}^{2}$ unburned plots, rill networks formed during simulated rainfall and reached a steady state after as little as $8 \%$ of total rainfall was applied, and persisted throughout the simulation (Bennett et al., 2015).

The expected increase in wildfire extent and severity in California may have critical implications for rill erosion and sediment yields in burned watersheds. MacDonald and Coe (2007) indicated the importance of headwater rills and channels in the transport of fine sediments downstream and throughout watersheds. However, little is known about how rill networks form over time within various burn severities in headwater catchments. The study objectives were to assess:

\footnotetext{
${ }^{1}$ Chapter 2 will be prepared and submitted to a peer reviewed journal in the future
} 
- The development of rill networks in different burn severities in the first year following wildfire

- The relationship between rill erosion and sediment yield in small catchments burned at varying severity

\section{$\underline{\text { 2.2 Site description }}$}

The Valley Fire started 12 September 2015 in the inland Coast Range of northern California and burned 30,783 ha, including portions of the Boggs Mountain Demonstration State Forest ("BMDSF") (Figure 2.1). Six areas of convergent hillslopes ("swales") of 0.15-0.65 ha were chosen with two swales in each class of low, medium, and high burn severity (Table 2.1).

Precipitation at BMDSF averages 1,650 mm annually (California Department of Forestry and Fire Protection, 2008) and vegetation is described as a Mediterranean California dry-mesic mixed conifer forest and woodland, with ponderosa pine (Pinus ponderosa), sugar pine (Pinus lambertiana), Douglas-fir (Pseudotsuga menziesii), manzanita (Arctostaphylos spp.), and oak (Quercus spp.) (US Geological Survey Gap Analysis Program (GAP), 2011).

At BMDSF, swale outlets ranged from 812 to $960 \mathrm{~m}$ in elevation. Soil families are the Collayomi, Aiken, and Whispering family, weathered from andesite parent material. Soils are gravelly to very gravelly loam (Soil Survey Staff, 2016).

\section{$\underline{2.3 \text { Field methods }}$}

Two swales were chosen in each class of low, moderate, and high burn severity based on USDA Forest Service Burned Area Reflectance Classification (BARC) maps (USDA, 2016) and field observations (Parsons et al., 2010). All six swales were characterized by varying degrees of converging hillslopes with a centralized channel leading to the outlet. Silt fences (adopted from Robichaud and Brown, 2002) were installed at the outlet of each swale in October 2015 (Figure 2.2). Swale slopes were derived from a $1 \mathrm{~m}$ digital elevation model created from airborne LiDAR data flown in 2016 by the Federal 
Emergency Management Agency, and the mean, minimum, and maximum slopes within each swale were calculated in ArcMap (ESRI, Redlands, CA).

Post-fire ground cover was characterized in the swales using three transects of varying lengths (adopted from Evans and Love, 1957) in November 2015. Cover types were recorded at $0.25 \mathrm{~m}, 0.5 \mathrm{~m}$, or $1.0 \mathrm{~m}$ intervals to achieve approximately 100 points per transect. Cover types were classified as bare soil, gravel (5-75 $\mathrm{mm}$ diameter), rock ( $>75 \mathrm{~mm}$ diameter), live vegetation, litter (pine needles, dead leaves, wood $<5 \mathrm{~mm}$ ), and wood ( $>5 \mathrm{~mm}$ diameter). Bare soil and gravel were combined to a single category. The percentages were averaged across all three transects for a single value for each swale.

Precipitation was recorded at the top of swale 5 using a tipping bucket rain gage (Rainwise Inc., Trenton, ME) coupled to a HOBO data logger (Onset Computer Corporation, Bourne, MA). The rain gage was installed November 2015. Precipitation events were separated by six hours of no rainfall for each event, and the total precipitation accumulation, duration, and maximum 10 minute, 30 minute, and 60 minute rainfall intensities $\left(\mathrm{I}_{10}, \mathrm{I}_{30}\right.$, and $\mathrm{I}_{60}$, respectively) were calculated for each event.

Rills and channels (Figure 2.2) were mapped in each swale in January 2016 and again in May 2016. From the outlet of each swale, each rill was followed with a mapping grade GPS in "track" mode to either the junction of the next upslope rill or its initiation point. All intersecting rills were followed to their initiation point. Drainage features where hillslopes converged to a single flow path and flow width was at least $20 \mathrm{~cm}$ wide were considered channels, and ended where hillslopes were no longer convergent or the channel transitioned to rills. Channels were mapped to their upslope terminus. If a rill diverged into two or more rills at least $1 \mathrm{~m}$ apart over a length of at least $1 \mathrm{~m}$, each rill was mapped separately. When multiple short rills less than $1 \mathrm{~m}$ in length formed and connected dendritically along a singular path less than $1 \mathrm{~m}$ wide and over $1 \mathrm{~m}$ long, the path was mapped and treated as a single rill. Rills not connected to the outlet were mapped when their length exceed $5 \mathrm{~m}$. Rill drainage density, or "rill density", was calculated by summing the lengths of rills connected to the outlet and dividing the total by the contributing area. The channel density was calculated in the same way, and the 
sum of rill and channel densities was used for the total drainage density. The rill length to the outlet was measured in ArcMap from the rill's initiation point to the swale outlet via connecting rills or channel flow paths.

Sediment was removed from the silt fences three times after installation. All six fences were cleaned out in March 2016 and June 2016. The moderate and high severity swale fences were also cleaned out in April 2016 when the fences were at risk of overtopping. Small sediment accumulations were removed and brought to the laboratory. For larger amounts, sediment was weighed in the field and a sub sample was taken to the laboratory, including eroded sediment that reached the fence but was deposited on the hillslope directly in front of the fence. In the laboratory the sub samples were dried for 24 hours at $105^{\circ} \mathrm{C}$ to determine water content. The field mass of sediment was then converted to a dry mass, which was divided by the contributing area to give a sediment yield for each swale. Sediment yields from all three clean outs were combined to give a cumulative value for the period of October 2015 to June 2016.

\section{$\underline{\text { 2.4 Statistical methods }}$}

All statistical analysis was done in the R software (R Core Team, 2016) using a significance level of 0.05. Linear mixed effects models were used to assess differences in rill density among burn severity over the two survey dates. Mixed models were built utilizing the lme4 package (Bates et al., 2014) with swale as a random effect. Fixed effects were burn severity and survey date measured as the number days since fire ignition and converted to a yearly timescale. Rill densities in the mixed model were square root transformed to normalize residuals. The lstrends function from the lsmeans package (Lenth, 2016) was used to compare the change in rill density over time for each burn severity using an interaction between severity and time, with a Tukey adjustment for multiple comparisons.

Simple linear regression models were built to assess the differences in bare soil, litter, wood, and rock cover, mean swale slope, number of rills, total rill length, rill density, and sediment yields by burn severity. Both the January and May values for the 
number of rills, total rill length, and rill densities were compared by burn severity. The lsmeans package was used to compare mean values between burn severities, with a Tukey adjustment for multiple comparisons.

Separate simple linear regression models were used to assess the relationship between the dependent variables of sediment yield and the May rill density, and each of the independent variables bare soil, litter, wood, and rock cover, number of rills, total rill length, channel density, and mean slope.

Model assumptions, including normality and homogeneity of variance of the residuals, were assessed by quantile-quantile plots and by plotting the residuals against predicted values (Winters, 2013). The models met the assumptions.

\section{$\underline{2.5 \text { Results }}$}

Cover

Bare soil increased with burn severity, from the minimum mean of $49 \%$ in low severity, to $58 \%$ in moderate severity, to $81 \%$ in high severity (Figure 2.3 ). There was no vegetation measured in any of the swales, and the ground cover was dominated by litter, regardless of burn severity. However, litter cover accounted for a mean of 41 and $35 \%$ cover in low and moderate burn severity swales, compared to $14 \%$ in high burn severity swales. Rock and wood both were minimal components of ground cover across all three burn severities; in low, moderate, and high burn severity rock was 9, 4, and 4\%, respectively, while wood was 2,3 , and $2 \%$, respectively. There were no significant differences across burn severities for either bare soil or any of the cover categories (Table 2.2). Individual swale ground cover data are available in Appendix A.

\section{$\underline{\text { Precipitation }}$}

Precipitation from November 2015 through June 2016 totaled 1,551 mm. The majority of precipitation occurred during the winter months of November through March, with approximately 70\% of the precipitation occurring in January and March 2016 (Figure 2.4). $513 \mathrm{~mm}$ of precipitation fell during January in 13 separate rain events, with 
a maximum $\mathrm{I}_{60}$ of $13 \mathrm{~mm} \mathrm{hr}^{-1}, \mathrm{I}_{30}$ of $14 \mathrm{~mm} \mathrm{hr}^{-1}$, and $\mathrm{I}_{10}$ of $15 \mathrm{~mm} \mathrm{hr}^{-1}$ with $63 \mathrm{~mm}$ of precipitation (Figure 2.5). During March, $571 \mathrm{~mm}$ of precipitation was recorded in 8 separate rain events, with a maximum $\mathrm{I}_{60}$ of $23 \mathrm{~mm} \mathrm{hr}^{-1}, \mathrm{I}_{30}$ of $27 \mathrm{~mm} \mathrm{hr}^{-1}$, and $\mathrm{I}_{10}$ of 37 $\mathrm{mm} \mathrm{hr}^{-1}$ with $245 \mathrm{~mm}$ of precipitation (Figure 2.5). Complete event precipitation data are available in Appendix B.

$\underline{\text { Rills }}$

Rill networks formed in five of the six swales by the January 2016 survey date, and in all six swales by May 2016. The low burn severity swale 1 was the only site with no rills in January 2016, and also had the highest post-fire ground cover. Rill density generally increased across the burn severity gradient and over time (Figure 2.6). The rills typically formed on bare hillslopes and connected downslope to the outlet via a channel. From January to May, the rill density in the two low severity swales, swale 1 and 2, increased slightly from 0.0 to $1.0 \mathrm{~cm} \mathrm{~m}^{-2}$ and 0.4 to $0.5 \mathrm{~cm} \mathrm{~m}^{-2}$, respectively. The moderate severity swale 3 increased from 1.0 to $2.1 \mathrm{~cm} \mathrm{~m}^{-2}$, and the rill network formed within the lower portion of the swale on bare hillslopes (Figure 2.7). Swale 6, which also burned at moderate severity, had a slight decrease in rill density, from $1.8 \mathrm{~cm} \mathrm{~m}^{-2}$ to $1.0 \mathrm{~cm} \mathrm{~m}^{-2}$. Increased litter from needle cast was observed between the two survey dates, and may have reduced rilling, caused in-rill deposition, or hidden some rills. The high severity swales, 4 and 5, increased from 3.8 to $23 \mathrm{~cm} \mathrm{~m}^{-2}$ and 5.1 to $19 \mathrm{~cm} \mathrm{~m}^{-2}$, respectively. The rills in high burn severity swales reached nearly the entire extent of the contributing areas by May 2016 (Figure 2.7). Individual rill measurements are available in Appendix C.

There was no significant difference in mean rill density between low and moderate severity swales in either survey date; however for each date the mean rill densities in both burn severities were significantly lower than the high severity swale means (Table 2.2). From January to May there was no significant changes in rill density between the low and moderate severity swales $(\mathrm{p}=0.57)$. However, the rill density in high burn severity swales increased at a significantly greater rate than the low $(p=0.04)$ and moderate $(p=$ 0.02) severity swales from January to May. In January there was no significant different in the number of rills between severities, but by May the high and low severity swales 
were significantly different $(p=0.048)$. Additionally, the total rill length was significantly different between high and low severity swales in January, however by May there were no significant differences in total rill lengths among severities. The channel densities showed slight increases between the two survey dates, however there were no significant differences either between surveys or among the burn severities.

The regression model indicated that the number of rills, total rill length, percent bare ground, and percent litter cover were significant predictors of rill density (Table 2.2). Rill density increased by $0.66 \mathrm{~cm} \mathrm{~m}^{-2}$ for each contributing rill $\left(\mathrm{r}^{2}=0.91\right)$. The regression slope for litter cover was $-0.63\left(\mathrm{r}^{2}=0.76\right)$ and $0.57 \mathrm{~cm} \mathrm{~m}^{-2}$ for bare ground $\left(\mathrm{r}^{2}=0.80\right)$. Wood and rock cover had a negative correlation with rill density, however the effects were not significant. Mean slope had no significant effect on rill density.

\section{$\underline{\text { Sediment }}$}

The mean sediment yields were $0.63 \mathrm{Mg} \mathrm{ha}^{-1}$ in the low severity swales, $2.1 \mathrm{Mg} \mathrm{ha}^{-1}$ in the moderate severity swales, and $14 \mathrm{Mg} \mathrm{ha}^{-1}$ in the high severity swales (Figure 2.8). There was no significant difference in mean sediment yield between the low and moderate burn severity swales, but both burn severities produced less sediment than the high severity swales. Following the March precipitation events, the moderate and high severity fences were cleaned out; the cleanouts represented $61-89 \%$ of the annual yield in the moderate severity swales, and $65-78 \%$ in the high severity swales. Sediment yields by clean out date are available in Appendix D.

Sediment yield had significant correlation with bare ground and litter cover, along with the number of rills and rill density (Table 2.2). Bare ground explained $92 \%$ of the variance in sediment yields with a slope of 0.41 , while litter explained $88 \%$ of the variance with a slope of -0.45 . While wood and rock decreased sediment yield in the model, both were not significant effects. Channel density was not a significant predictor of sediment yield ( $\mathrm{p}=0.6, \mathrm{r}^{2}=0.07$ ). The number of contributing rills explained $85 \%$ of the variance in sediment yields $(p=0.008)$, while the total rill length explained $84 \%$ of the variance $(p=0.01)$, however the residual error for each variable was high $(2.90$ and 
3.07 , respectively). Rill density explained $97 \%$ of the variance in sediment yields, and was the most significant predictor $(\mathrm{p}=0.0004)$, with the lowest residual standard error (1.38).

\section{$\underline{\text { 2.6 Discussion }}$}

The result that rill density explained approximately $97 \%$ of the variance in sediment yields partially corroborates Pietraszek's (2006) estimate that $60-80 \%$ of eroded sediment in burned areas is sourced from rills. The high level of correlation between rill density and sediment yield indicates that rill erosion is a dominant sediment transport mechanism on burned hillslopes, accounting for a majority of sediment yields within our swales. Moody and Martin (2009) used a synthesis of post-fire sediment yields to illustrate that as spatial scale increased from hillslope $\left(1-1000 \mathrm{~m}^{2}\right)$ to catchment (100-10,000 ha), sediment yields increased when channel processes dominated, and approximately $75 \%$ of sediment was sourced from channels. Our study did not find a significant correlation between channel density and sediment yield, but we also recognize that the ephemeral channels within the swales at BMDSF were relatively small and also relatively short. This study indicates that as spatial scale decreases to the swale scale seen at BMDSF, hillslope rill erosion is a more dominant process than channel erosion in the first year following wildfire. At the small headwater catchment scale channels may have less runoff volume and available sediment than at the large catchment scale in Moody and Martin's (2009) study. Instead, rill erosion accounts for the majority of sediment yields, while channels act as a connecting feature to the outlet.

There may be different processes occurring within ephemeral channels such as those found in the BMDSF swales relative to within rills; rills on steep slopes may become source limited over time (Wagenbrenner et al., 2010), while channels, which can store sediment, can be transport limited and deliver only some available sediment. High intensity precipitation may remove or reduce the transport limitation, allowing greater sediment delivery (Blake et al., 2009). At BMDSF, the interacting effects of wildfire and high intensity precipitation events (such as those observed during March 2016) may have 
worked to "flush" sediment sourced from hillslopes and stored in channels to the swale outlet at a later time.

Within the low to moderate burn severity swales, the increased surface roughness from greater ground cover may have caused deposition on the hillslopes, as has been demonstrated in rill networks on unburned slopes (Gomez et al., 2003). Previous research has shown that needle cast from Douglas-fir and ponderosa pine, two species present at BMDSF, can significantly reduce erosion following wildfires (Pannkuk and Robichaud, 2003). The high rates of litter cover in the low and moderate severity swales consisted mostly of needles, which supports the role of post-fire needle cast in reducing soil erosion. However, the ground cover in the high severity swales, despite being largely litter, only averaged 19\%. Harrison et al. (2016) indicated that significant reductions in sediment yield in burned areas occurred at $25 \%$ ground cover or more.

In high burn severity areas, individual rills connect downslope and runoff accumulates, leading to increased energy capable of eroding more sediment downslope. The increased connectivity in the high burn severity areas allowed eroded sediment from both the mid and upper slopes to be delivered to the channels, in addition to sediment available from the lower slopes, elevating sediment yields.

In Bennett et al.'s (2015) controlled rill experiments, rill networks had reached a steady state following between $8-26 \%$ of the total applied rainfall. At the time of the January rill survey, cumulative post-fire rainfall was $22 \%$ of the amount for the first postfire year. By the May survey, approximately $99 \%$ of the first-year rainfall had been recorded, and rill densities in the high severity swales had increased significantly more than the low and moderate severity swales. During the month of March, the rainfall that fell in eight separate events was $37 \%$ of the total rainfall. $16 \%$ of the rainfall occurred in one storm (March 3-7), with a maximum $\mathrm{I}_{60}$ of $23 \mathrm{~mm} \mathrm{hr}^{-1}$. During the month of March $65-78 \%$ of the annual sediment yield in the high severity swales was measured. High intensity precipitation events likely influence rill networks in all swales and burn severities more so than overall annual rainfall, which likely also holds true for sediment yields. However, the response of rill networks and sediment yields in high burn severity 
swales to intense rain events was likely much greater than in lower burn severities. Management to mitigate post-fire erosion rates in headwater catchments, when resources are limited, should focus on severely burned areas due to the sensitivity of these areas to high intensity rain events and the greater potential sediment delivery.

Rills in burned forests have elevated runoff and sediment flux rates compared to unburned forests (Robichaud et al., 2010), and sediment flux rates in rills can be limited by soil availability (Wagenbrenner et al., 2010), which can be highest at the soil surface (Nyman et al., 2013). The initial erosion rates observed at BMDSF are likely highly influenced in part by the high sediment availability at the soil surface following the wildfire, particularly in the high severity swales that had extensive exposed bare soil.

The rill densities and sediment yields in our high severity swales were an order of magnitude higher than the low-moderate severity swales. Assuming the unburned hillslopes would have even lower rates of rilling and sediment delivery (Moody and Martin, 2009), the high severity burn areas would produce orders of magnitude greater rill densities and sediment yields than unburned catchments. While post-fire erosion is a natural process, erosion rates that are magnitudes higher than unburned forests, at such large spatial scales, could pose a threat to downstream resources and infrastructure. Our study indicated that rill density responded to bare soil and litter cover at a relatively equal rate (slopes of 0.57 and -0.63 , respectively), and sediment yields responded to bare soil and litter cover in a similar fashion (slopes of 0.41 and -0.45 , respectively). In terms of management, this study indicates that mitigation techniques that increase post-fire ground cover should reduce both rill development and sediment yields, corroborating previous research (Wagenbrenner et al., 2006, Robichaud et al., 2013a, Robichaud et al., 2013b).

\subsection{Conclusion}

Very little is known about post-fire erosion rates in the inland Coast Range of California, and how rills networks develop on hillslopes burned at varying intensities. Rills can be a dominant soil erosion and sediment transport mechanism in burned forests, and connect hillslopes to ephemeral channels and stream networks. Following the 2015 
Valley Fire in the inland Coast Range of California, we measured rill density and sediment yields in six swales with varying burn severities. Approximately $1,551 \mathrm{~mm}$ of precipitation was recorded in the first year after the fire, and most of this occurred between November and March, including several large, high intensity precipitation events during March. Rill densities and sediment yields were significantly correlated to bare ground, while increases in litter cover significantly reduced rilling and sediment yields. Ground cover decreased with burn severity, and litter cover was higher in moderate and low severity swales. This resulted in significantly higher average rill densities in high burn severity swales $\left(21 \mathrm{~cm} \mathrm{~m}^{-2}\right)$ as compared to swales of low or moderate severity $\left(0.8 \mathrm{~cm} \mathrm{~m}^{-2}\right.$ and $1.6 \mathrm{~cm} \mathrm{~m}^{-2}$, respectively). Rill density in high severity swales increased more between survey dates than low to moderate severity swales. Rill density and sediment yield were highly correlated. From these results and previous studies we infer that rill density is an important hillslope surface sediment transport mechanism in burned forests in the Coast Range, and that both rill density and sediment yields are highly dependent on burn severity. 


\section{$\underline{\text { 2.8 Tables and Figures }}$}

Table 2.1: Study swale characteristics at BMDSF within the Valley Fire area, including burn severity, mean, minimum, and maximum slope, and contributing area.

\begin{tabular}{cccc}
\hline Swale & Burn severity & $\begin{array}{c}\text { Mean slope and } \\
\text { range (\%) }\end{array}$ & Area (ha) \\
\hline Swale 1 & Low & $37(20-57)$ & 0.26 \\
Swale 2 & Low & $43(25-59)$ & 0.15 \\
Swale 3 & Moderate & $27(13-50)$ & 0.65 \\
Swale 4 & High & $35(14-69)$ & 0.29 \\
Swale 5 & High & $36(8-76)$ & 0.18 \\
Swale 6 & Moderate & $37(7-68)$ & 0.20 \\
\hline
\end{tabular}


Table 2.2: Statistical results. A) Variable differences between mean values by burn severity. Range shown in parentheses, and different superscripts in each row indicate significantly different means. B) Regression summaries for sediment yield and rill density and single independent variables.

A

Variable

High severity Moderate severity Low severity

\begin{tabular}{|c|c|c|c|c|}
\hline Bare ground (\%) & $81(78-84)^{A}$ & \multicolumn{2}{|c|}{$58(50-66)^{A}$} & $49(45-53)^{\mathrm{A}}$ \\
\hline Litter $(\%)$ & $14(13-14)^{\mathrm{A}}$ & \multicolumn{2}{|l|}{$35(29-41)^{\mathrm{A}}$} & $41(33-49)^{\mathrm{A}}$ \\
\hline Wood (\%) & $1.6(1.5-1.6)^{\mathrm{A}}$ & \multicolumn{2}{|c|}{$3.4(3-3.8)^{\mathrm{A}}$} & $1.6(1-2.2)^{\mathrm{A}}$ \\
\hline Rock (\%) & $3.9(1.6-6.1)^{\mathrm{A}}$ & \multicolumn{2}{|c|}{$3.6(0.6-6.6)^{\mathrm{A}}$} & $8.9(5.6-12)^{\mathrm{A}}$ \\
\hline Mean slope (\%) & $36(35-36)^{\mathrm{A}}$ & \multicolumn{2}{|c|}{$32(27-37)^{\mathrm{A}}$} & $40(37-43)^{\mathrm{A}}$ \\
\hline Rill length (m) (Jan) & $102(91-113)^{\mathrm{A}}$ & \multicolumn{2}{|c|}{$60(35-67) \stackrel{\mathrm{AB}}{ }$} & $3(0-6)^{\mathrm{B}}$ \\
\hline Rill length (m) (May) & $503(343-663)^{A}$ & \multicolumn{2}{|c|}{$77(21-134)^{\mathrm{A}}$} & $17(8-27)^{\mathrm{A}}$ \\
\hline Rill count (Jan) & $8(7-9)^{\mathrm{A}}$ & \multicolumn{2}{|c|}{$6(4-8)^{\mathrm{A}}$} & $1(0-1)^{\mathrm{A}}$ \\
\hline Rill count (May) & $31(23-38)^{\mathrm{A}}$ & \multicolumn{2}{|l|}{$7(3-11)^{\mathrm{AB}}$} & $1(1)^{\mathrm{B}}$ \\
\hline Rill density $\left(\mathrm{cm} \mathrm{m}^{-2}\right)$ (Jan) & $4.5(3.8-5.1)^{\mathrm{A}}$ & \multicolumn{2}{|c|}{$1.4(1.0-1.8)^{\mathrm{B}}$} & $0.2(0-0.4)^{\mathrm{B}}$ \\
\hline Rill density $\left(\mathrm{cm} \mathrm{m}^{-2}\right)$ (May) & $21(19-23)^{\mathrm{A}}$ & \multicolumn{2}{|c|}{$1.6(1.0-2.1)^{\mathrm{B}}$} & $0.8(0.5-1.0)^{\mathrm{B}}$ \\
\hline Yield $\left(\mathrm{Mg} \mathrm{ha}^{-1}\right)$ & $14(13-15)^{\mathrm{A}}$ & \multicolumn{2}{|c|}{$2.1(0.8-3.4)^{\mathrm{B}}$} & $0.63(0.05-1.2)^{\mathrm{B}}$ \\
\hline \multicolumn{5}{|l|}{ B } \\
\hline Variable & $\mathrm{P}$ value & $\begin{array}{l}\text { Slope } \\
\text { coefficient }\end{array}$ & $r^{2}$ & $\begin{array}{l}\text { Residual } \\
\text { standard error }\end{array}$ \\
\hline \multicolumn{5}{|l|}{ Rill Density $\left(\mathrm{cm} \mathrm{m}^{-2}\right)$ (May) } \\
\hline Bare ground $(\%)$ & 0.02 & 0.57 & 0.8 & 5.2 \\
\hline Litter (\%) & 0.02 & -0.63 & 0.76 & 5.6 \\
\hline Wood $(\%)$ & 0.4 & -4.1 & 0.18 & 10.4 \\
\hline Rock (\%) & 0.5 & -0.9 & 0.12 & 10.8 \\
\hline Mean slope (\%) & 0.84 & -0.22 & 0.01 & 11.5 \\
\hline Number of rills & 0.003 & 0.66 & 0.91 & 3.41 \\
\hline Channel density $\left(\mathrm{cm} \mathrm{m}^{-2}\right)$ & 0.70 & 2.3 & 0.04 & 11.4 \\
\hline \multicolumn{5}{|l|}{ Sediment Yield $\left(\mathrm{Mg} \mathrm{ha}^{-1}\right)$} \\
\hline Bare Ground (\%) & 0.003 & 0.41 & 0.92 & 2.2 \\
\hline Litter $(\%)$ & 0.006 & -0.45 & 0.88 & 2.66 \\
\hline Wood (\%) & 0.56 & -1.94 & 0.09 & 7.23 \\
\hline Rock (\%) & 0.43 & -0.67 & 0.16 & 6.95 \\
\hline Mean slope (\%) & 0.96 & -0.04 & 0 & 7.59 \\
\hline Channel density $\left(\mathrm{cm} \mathrm{m}^{-2}\right)$ & 0.61 & 2.0 & 0.07 & 7.31 \\
\hline Number of rills & 0.008 & 0.42 & 0.85 & 2.90 \\
\hline Rill length (m) & 0.01 & 0.02 & 0.84 & 3.07 \\
\hline Rill density $\left(\mathrm{cm} \mathrm{m}^{-2}\right)$ & 0.0004 & 0.65 & 0.97 & 1.38 \\
\hline
\end{tabular}




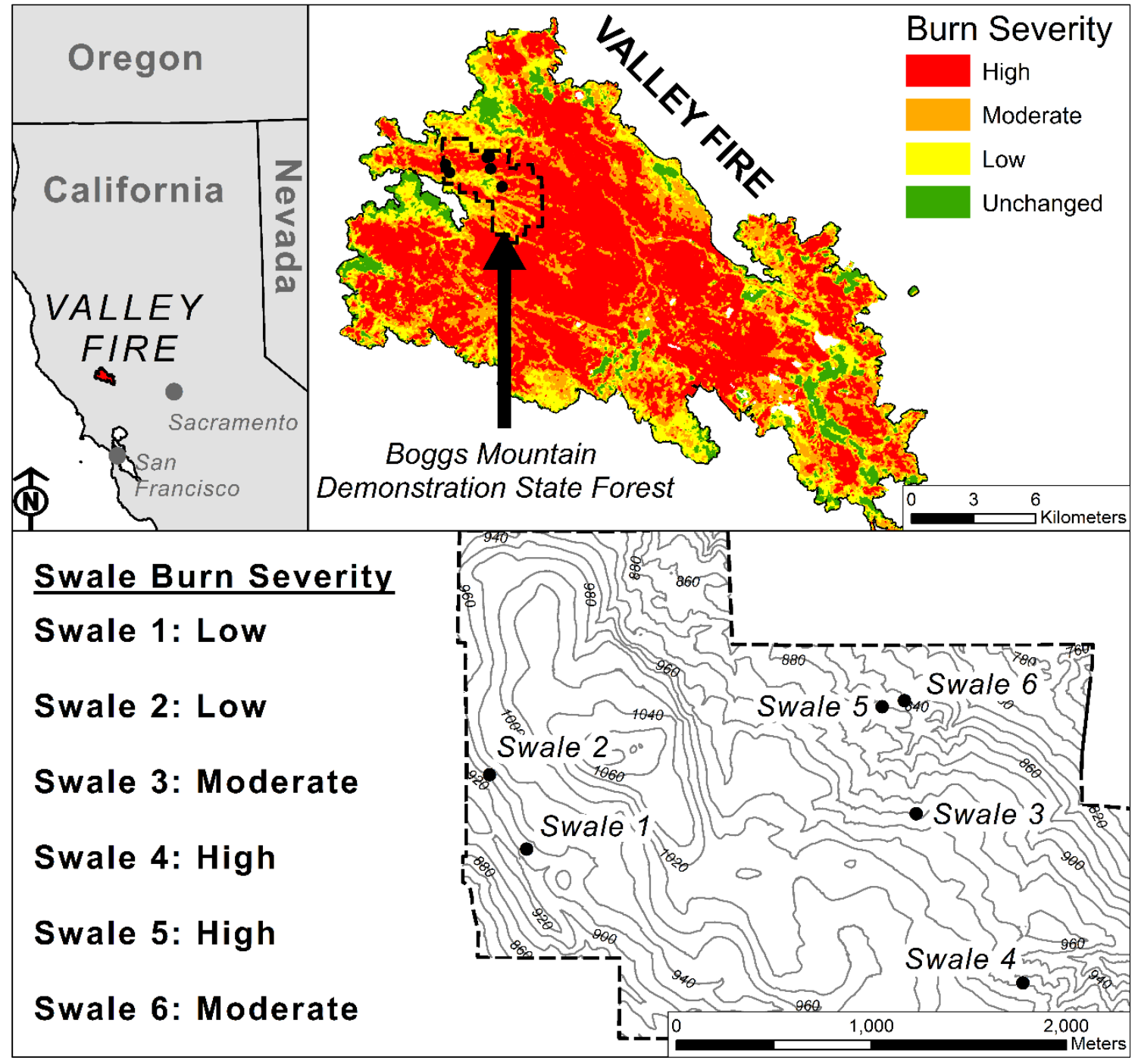

Figure 2.1: Valley Fire and location of BMDSF within the burned area. Lower panel shows swale locations within BMDSF. Burn severity is from the USDA Forest Service burned area reflectance classification data (USDA, 2016). 


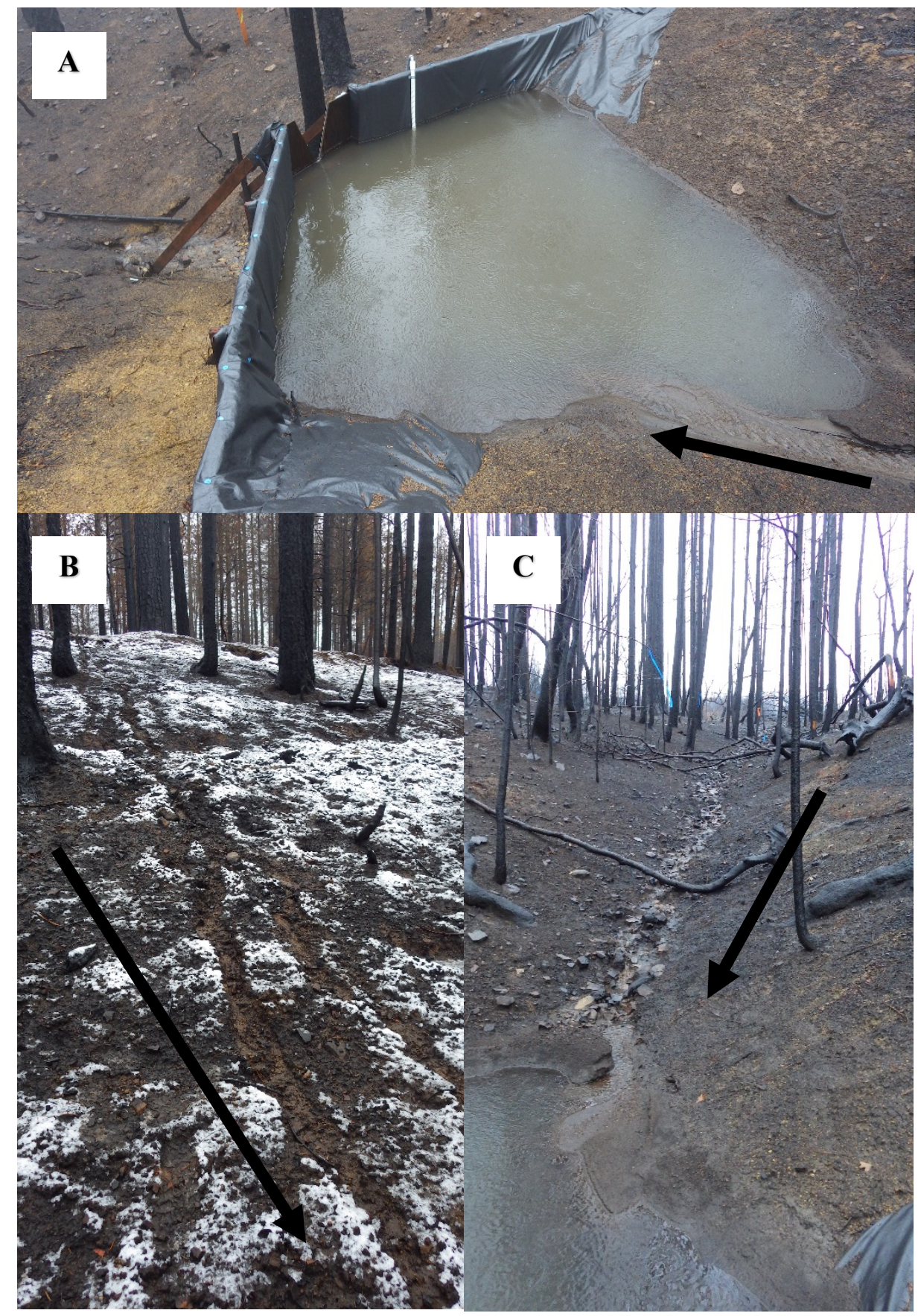

Figure 2.2: Photos of a partially filled silt fence following rainfall (A), rill erosion (B), and an ephemeral channel (C). Arrows indicate downslope direction. 


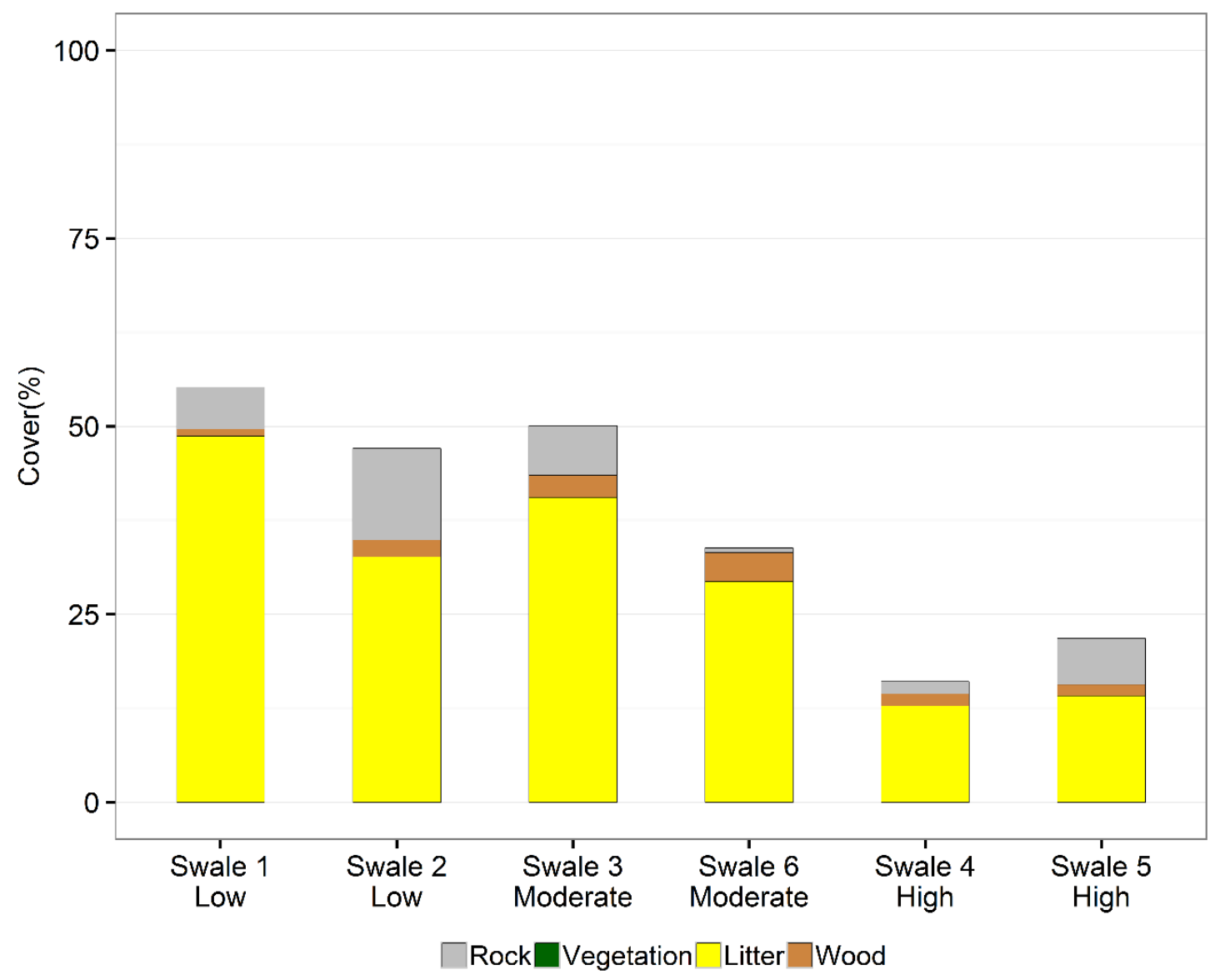

Figure 2.3: Ground cover at BMDSF, November 2015, approximately one month postfire. "Low", "Moderate", and "High" refer to burn severity in each swale. Litter was the dominant cover type, and ground cover decreased with increasing burn severity. $100 \%$ minus the total ground cover is the amount of bare ground. 

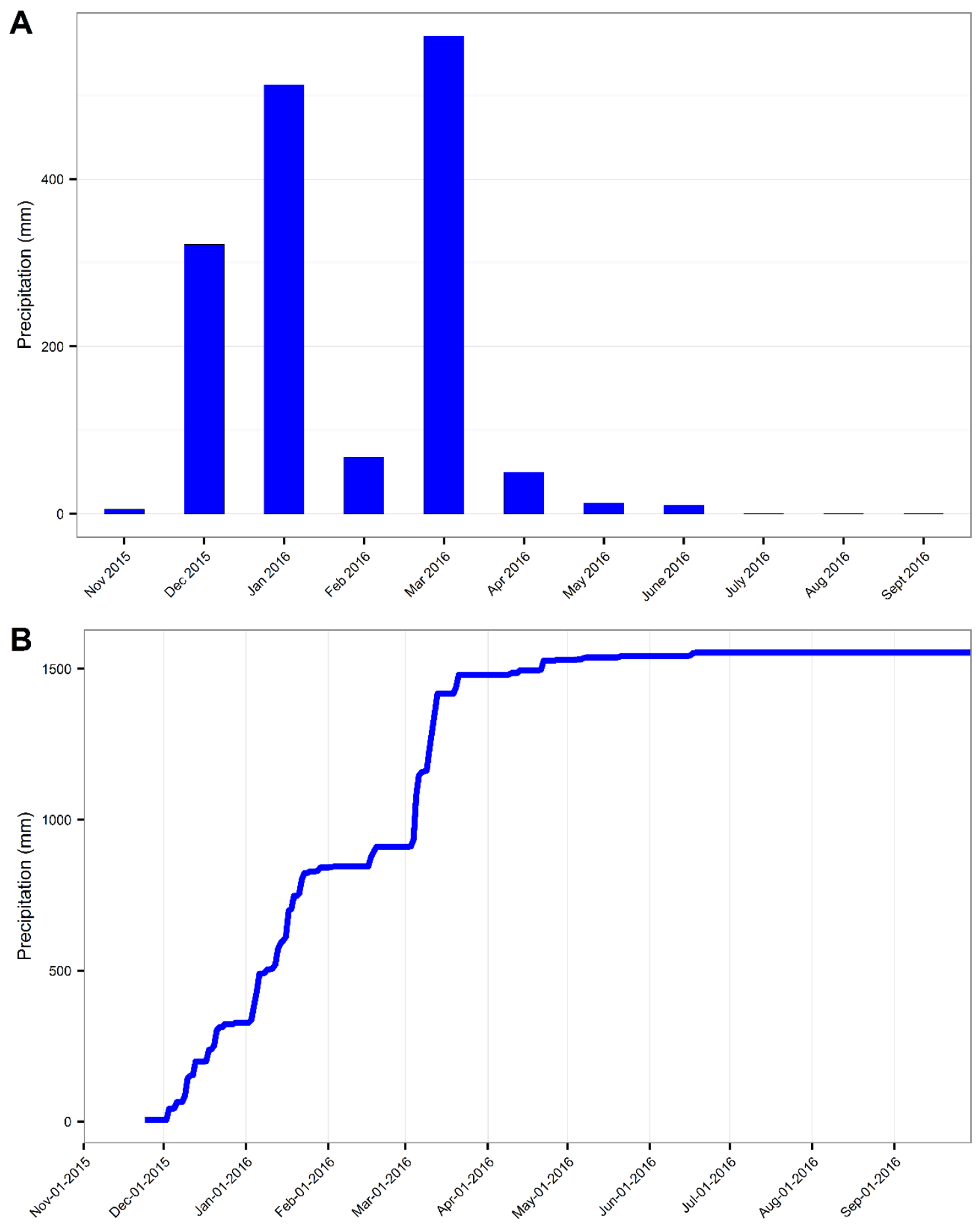

Figure 2.4: Rainfall at the top of swale 5 at BMDSF. Panel $A$ is monthly cumulative rainfall, panel $B$ shows the daily rainfall throughout the year. Only trace rainfall amounts occurred between 1 October and gage installation on 14 November 2015. 

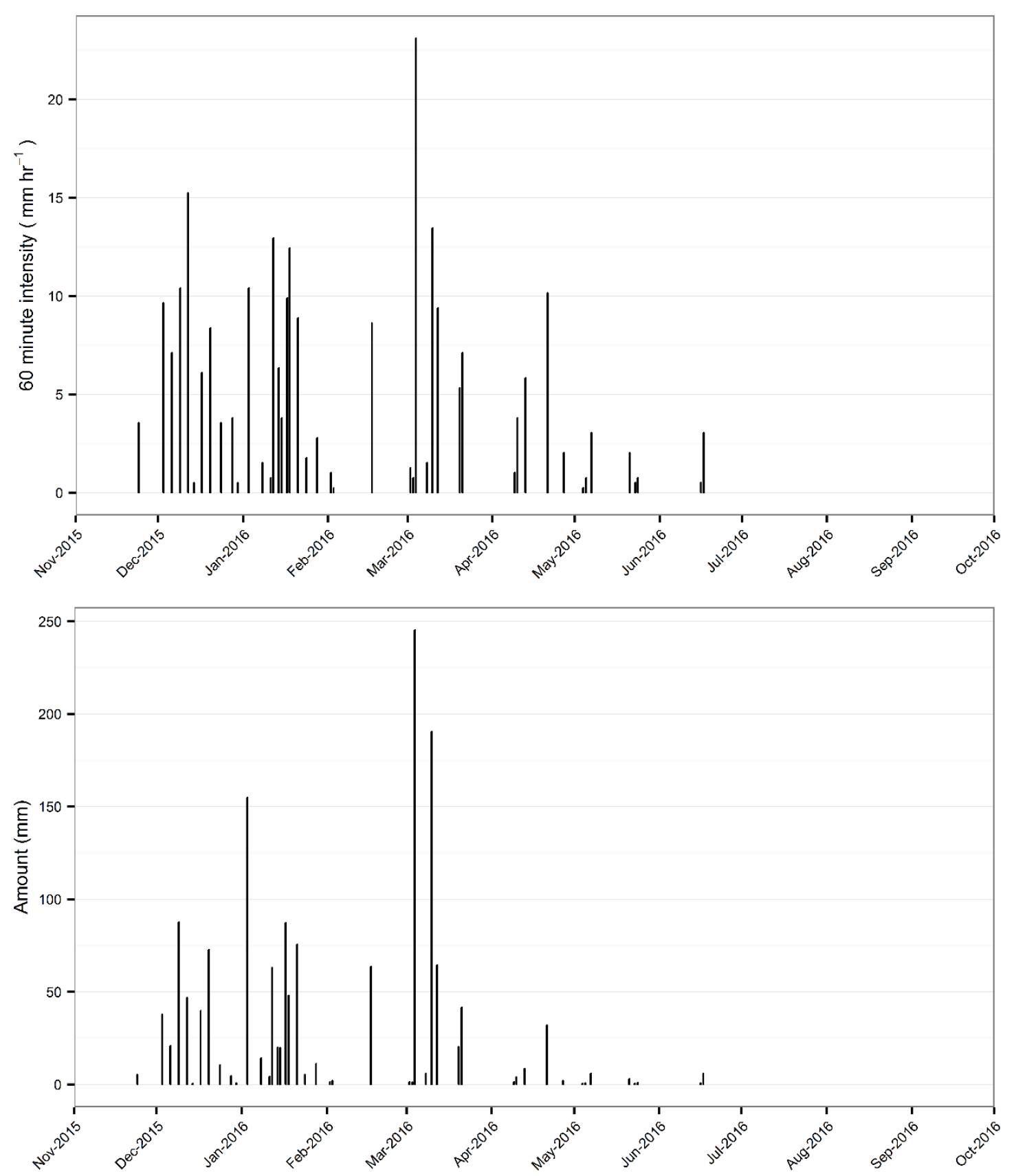

Figure 2.5: 60-minute maximum rainfall intensity $\left(I_{60}\right)$ by rainfall event (top) and cumulative rainfall by event (bottom) at BMDSF. Only trace rainfall amounts occurred between 1 October and gage installation on 14 November 2015. 


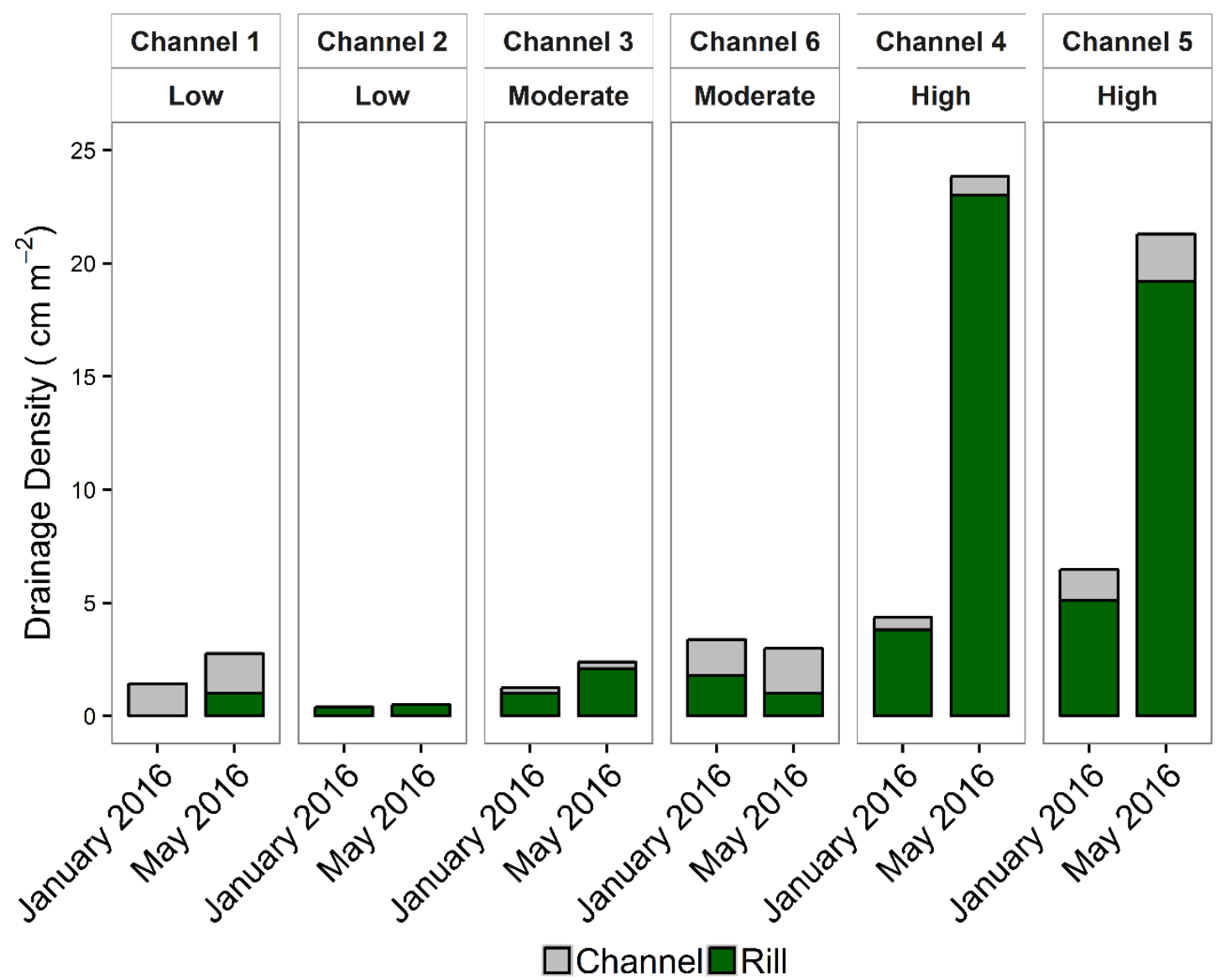

Figure 2.6: Rill and channel densities by swale number and burn severity at BMDSF for each survey date. 


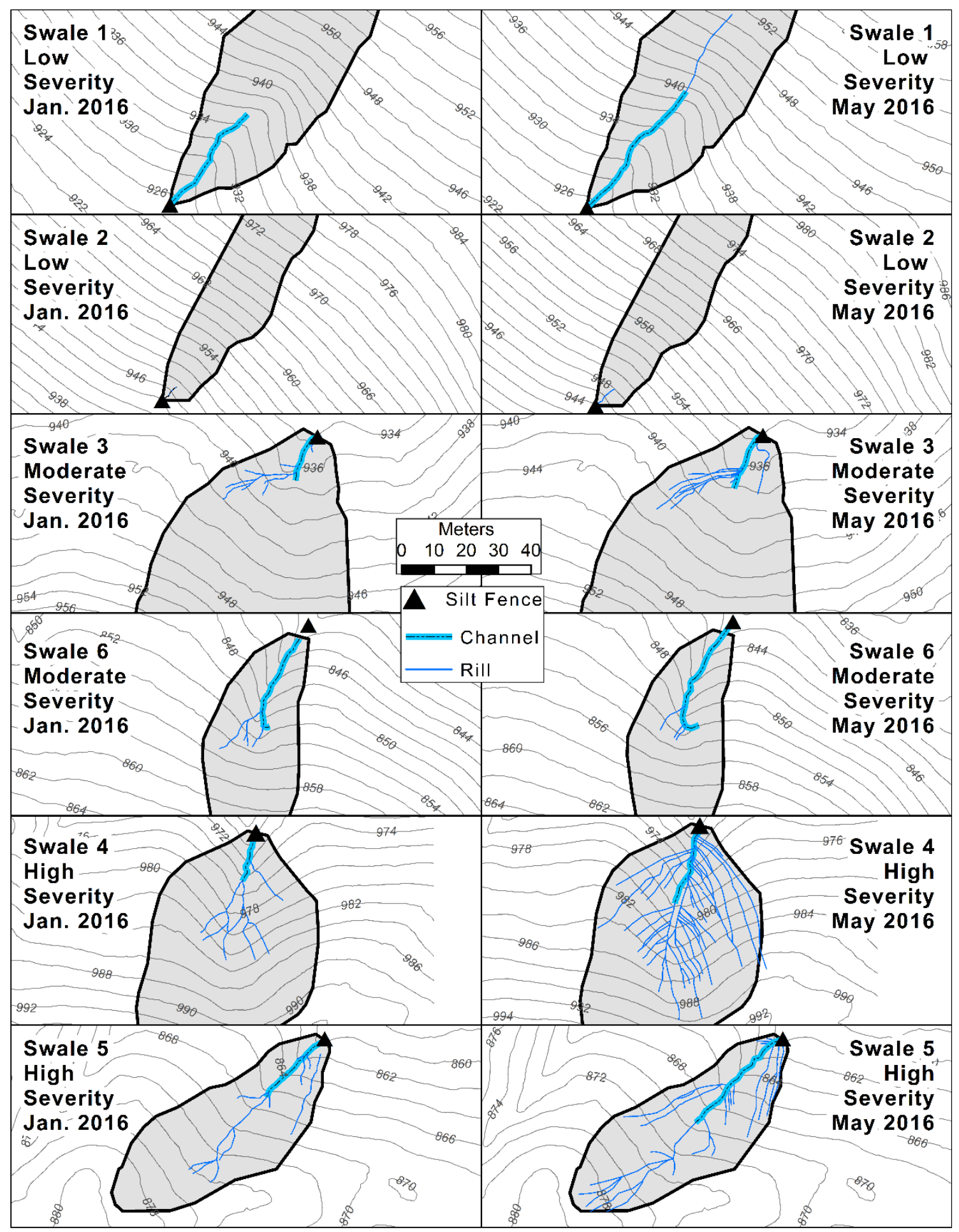

Figure 2.7: Rill networks in BMDSF swales in January 2016 (Left) and May 2016 (Right). Scale in each map is 1:1300. 


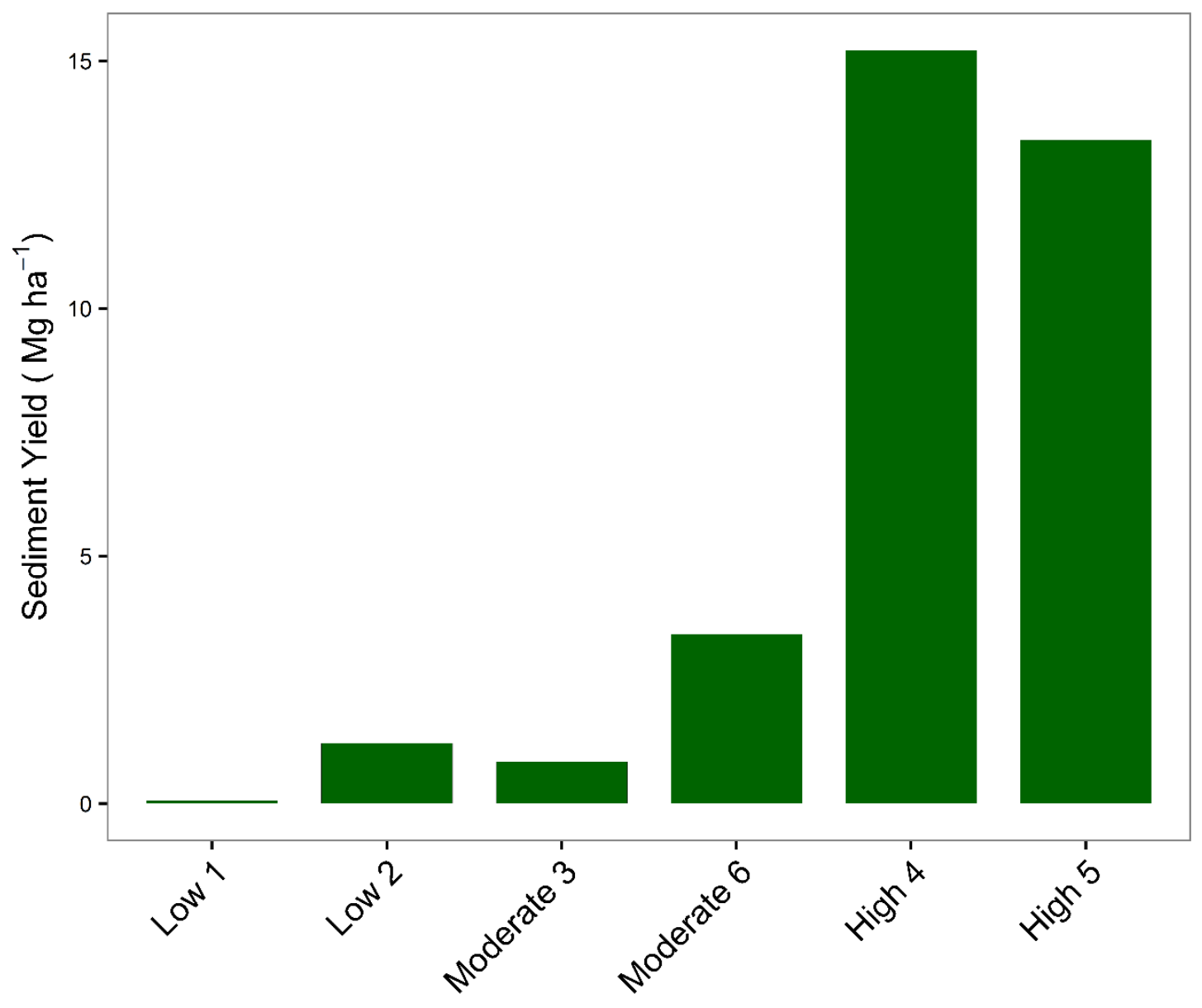

Figure 2.8: Sediment yields by swale and burn severity at BMDSF from October 2015 to June 2016. No additional sediment was produced through September 2016. 


\section{Chapter 3: Effect of post-fire salvage logging on rill network formation and sediment yields ${ }^{2}$}

\section{$\underline{\text { 3.1 Background }}$}

Post-fire salvage logging presents a special concern in regards to potential impacts to watersheds and aquatic environments (Karr et al., 2004). In a review of research on the effects of salvage logging on erosion, the use of ground-based harvesting techniques was identified as the most likely to have detrimental effects (McIver and Starr, 2001). Ground based harvesting techniques typically involve the use of tracked feller bunchers to cut and bunch trees, and wheeled or tracked skidders to drag or "skid" whole trees to a central area for processing and loading onto log trucks for transport to sawmills for processing (Figure 3.1). Routes used by skidders to retrieve trees are typically referred to as "skid trails".

Salvage logging techniques can be an important factor in determining soil disturbance. The use of skyline yarding, which elevates one end of the log off the soil surface, led to minimal soil disturbance in an Oregon study (Slesak et al., 2015). The disturbance from ground based logging equipment during salvage operations can be extensive, with high spatial variation of mechanical disturbance within and among catchments (Chou et al., 1994). Cable suspension and ground based harvesting methods resulted in significantly higher soil disturbance than helicopter based logging in the California Sierra Nevada, and bare soil from salvage activity was indicated as a direct factor for elevated sediment yields (Chase, 2006). During ground based salvage of burned areas in Oregon, increasing intensities of tree removal were found to correspond to increased mechanical soil disturbance (McIver and McNeil, 2006).

Extensive soil disturbance from salvage logging does not always correlate to elevated sediment yields. Chou et al. (1994) indicated the difficulty in differentiating erosion from fire effects and logging effects in their California study. Low post-salvage rainfall amounts and intensities, coupled with hand felling of trees, skidding over snow,

\footnotetext{
${ }^{2}$ Chapter 3 will be prepared and submitted to a peer reviewed journal in the future
} 
and low to moderate erosion risk soils, led to minimal sediment transport in burned and logged areas in Oregon (McIver and McNeil, 2006). Slesak et al. (2015) noted that elevated sediment yields were more likely due to coupled effects of herbicide-based vegetation control and mechanical site preparation, in conjunction with high intensity rain events, rather than salvage logging alone. Site to site variability resulted in insignificant differences in sediment yields between helicopter, cable, and tractor based salvage techniques in California (Chase, 2006). A study comparing burned and burned and logged catchments in Arizona indicated that salvage logging had no discernible effect on sediment yields, which were tied more closely to bare soil and slope (Stabenow et al., 2006). In northwestern Spain, the combination of salvage logging and application of mulch after wildfire reduced sediment yields at the plot scale relative to both logged and unlogged plots that were not mulched (Fernandez and Vega, 2016).

Salvage logging has been identified as a potential tool to reduce post-fire soil erosion rates through the application of logging slash to cover bare ground and by breaking up water repellant layers (Poff, 1989). This study indicated the careful planning, management, and monitoring involved were key to protecting watersheds within the burned area. Soil disturbance from logging equipment can break up soil water repellant layers (Wagenbrenner, 2015) and increase surface roughness (Poff, 1989), which was indicated as a factor in reducing post-fire sediment yields at the catchment scale in one study (James, 2014). James's study (2014) also indicated the subsequent contour ripping of soils reduced spatial connectivity and sediment delivery to catchment outlets.

During simulated rill experiments in burned and trafficked areas in Oregon and Washington, the maximum sediment flux rate occurred within skid trails, however there was no difference in sediment flux between skid trails and plots with high soil burn severity (Robichaud et al., 2010). Robichaud et al.'s (2010) study also documented the increased soil erodibility in recently burned forests and subsequent disturbance from skidding. Across several fires in the western US, the type of logging equipment and amount of traffic did not significantly alter sediment fluxes, and trafficked plots produced sediment flux rates several orders of magnitude higher than unlogged plots in simulated rill experiments (Wagenbrenner et al., 2016). The latter study also indicated decreased 
infiltration rates in skidder plots as a critical factor for elevated sediment flux rates, and this negative effect overrode the reduction in water repellency caused by the traffic (Wagenbrenner et al., 2016).

Spatial layout and hydrologic connectivity of logging disturbance may be a critical factor in determining erosion rates. In the Rocky Mountain region of Alberta, Canada, sediment transport pathways to downstream aquatic systems were created by disturbance features from logging activity in burned forests that were not observed in burned-only watersheds (Silins et al., 2009). A 2014 study from the same Alberta, Canada wildfire used a geochemical fingerprinting method to determine sediment sources, finding that both burned and burned and logged watersheds had persistently high sediment inputs in the years following fire (Stone et al., 2014). In several different burned areas in the western US, sediment yields from skid trails at the hillslope scale were found to be significantly elevated relative to burned and unlogged control plots (Wagenbrenner et al., 2015). Wagenbrenner et al.'s (2015) study also found that sediment yields between logged and unlogged areas at the larger catchment scale were dependent upon both site and location; sediment yields corresponded strongly to rainfall intensity and bare soil, with the layout and connectivity of skid trails critical aspects in determining the effect of post-fire logging.

Determining the sediment sources and connectivity of disturbance from ground based tractor harvesting to stream networks in burned and logged areas will greatly improve our ability to understand, predict and mitigate erosion from post-fire logging. The objectives of this study were to:

- Assess the impacts of post-fire salvage logging on soil bulk density, field saturated hydraulic conductivity rates, and ground cover;

- Identify where rills initiate in burned and burned and logged catchments;

- Assess the impact of post-fire salvage logging on the connectivity of rills across burned hillslopes to the stream network;

- Assess the relationships between sediment yields and rill networks, post-fire logging disturbance, and ground cover. 


\section{$\underline{\text { 3.2 Site description }}$}

The Rim Fire started 17 August 2013 in the western side of the central Sierra Nevada in California and burned 103,773 ha, including 62,536 ha of the Stanislaus National Forest (Figure 3.2). Fourteen swales of $0.09-0.81$ ha were chosen across three timber harvest units within the Rim Fire burned area in the Stanislaus National Forest. Swale outlets ranged from $1,170 \mathrm{~m}$ to $1,447 \mathrm{~m}$ in elevation, and the mean slope of swales ranged from 15-27\% (Table 3.1). Seven swales were chosen within the "Triple A" sale, and seven swales were chosen within the "Femmons" sale, which consisted of two units, Lower and Upper Femmons, with four and three swales each, respectively.

The 1981-2010 annual average precipitation for Triple A was $937 \mathrm{~mm}$ (Mather rain gage, Western Regional Climate Center, 2016). For Femmons, precipitation at the nearby Cherry Valley Dam rain gage (37.975 N, -119.916 W) averaged 1,283 mm annually from 1981-2010 (Western Regional Climate Center, 2016). Vegetation in swales was described as a Mediterranean California dry-mesic mixed conifer forest and woodland (US Geological Survey Gap Analysis Program (GAP), 2011). Tree species were a mixture of ponderosa pine (Pinus ponderosa), incense cedar (Calocedrus decurrens), sugar pine (Pinus lambertiana), Douglas-fir (Pseudotsuga menziesii), and oak (Quercus spp.). Manzanita (Arctostaphylos spp.) species were also found interspersed within the study area, particularly in the Upper Femmons unit (US Geological Survey Gap Analysis Program (GAP), 2011).

Soils were Holland family, with a loam surface over sandy clay loam weathered from granitic parent material with 3-10\% rock (Soil Survey Staff, 2016). A portion of the swale FSW 11 in Lower Femmons was a Holland-McCarthy complex, consisting of loam over sandy clay loam and gravelly sandy loam over sandy loam, weathered from tuff and paralithic parent material. The three high elevation swales in Upper Femmons had soils of the Josephine and Sites families, weathered from paralithic parent material. These soils were classified as gravelly loam over clay loam or clay, and $10-30 \%$ rock. 
The prevalence of manzanita, rockier soils, and much lower impact of logging operations in Upper Femmons led us to separate it from the Lower Femmons unit for all analysis, despite being within the same timber sale boundary.

Swale treatments were burned and unlogged ("control"), and burned and logged ("logged") (Figure 3.3, Table 3.1). Five of seven swales in Triple A were logged during November to December 2014; three of four swales in Lower Femmons were logged in May 2015; and one of three swales in Upper Femmons was logged in September 2015 (Table 3.1). Feller bunchers were used to cut trees, except for large trees, which were hand felled. Cut trees were skidded to landings by rubber-tired skidders.

\subsection{Field methods}

Swales were chosen using data from the USDA Forest Service Burned Area Reflectance Classification (BARC) maps (USDA, 2016) and field observations (Parsons et al., 2010). In the Rim Fire, all logged swales were chosen in areas of high burn severity within timber harvest boundaries. Control swales were also located within high burn severity areas and timber harvest boundaries, and all logging activity was excluded within the swale boundaries. Silt fences (adopted from Robichaud and Brown, 2002) were installed at the outlet of each swale following salvage logging in each unit. Each fence had an electronic stage sensor (Milone Technologies, Sewell, NJ) to record when runoff occurred. Swale slopes were calculated using the same methods as in chapter two using ArcMap and a $1 \mathrm{~m}$ digital elevation model (Stavros et al., 2016). The stumps in each logged swale were counted and used as a surrogate for trees removed to characterize harvest intensity.

Patches of similar disturbance were surveyed using a mapping grade GPS unit with sub-meter accuracy, and all GPS data were differentially corrected and postprocessed in ArcMap. Disturbed areas were classified into five classes: untrafficked by logging equipment; feller buncher tracks; mixed traffic areas which had a heterogeneous mix of disturbed and undisturbed soil, often with high slash surface cover and no clear indication of which piece of equipment created the disturbance; low traffic skid trails where six or fewer one-way skidder passes were made, some soil cover was retained, and ruts were less than $10 \mathrm{~cm}$ deep; and high traffic skid trails where the main skidding routes 
were located, where more than six skidder passes occurred and the soil cover was removed (Figure 3.4). A sixth disturbance class, subsoiled, occurred and was surveyed in logged swales ASW 3 and FSW 10 in 2016; bulldozers equipped with "winged" shanks created furrows in the soil in order to decrease compaction and increase infiltration along skid trails in these swales (Figure 3.5). ASW 3 was subsoiled September 2015, and FSW 10 was subsoiled in May 2016. Waterbars, which were installed on skid trails as a best management practice to divert water off the skid trails, were also surveyed in the field. The distance from the waterbar outlet to the swale outlet was measured in ArcMap.

Ground cover measurements were made along three transects in each swale in 2014, 2015, and 2016. Ground cover, soil bulk density, and field saturated hydraulic conductivity were made within areas of homogenous logging disturbance following logging.

Soil bulk density samples were taken in both untrafficked areas and in each class of disturbance in each swale in 2015 following logging. Samples were obtained by using a slide hammer to insert a $90.5 \mathrm{~cm}^{3}$ core into the soil to a target depth of either $0-5 \mathrm{~cm}$ or $5-10 \mathrm{~cm}$ below the surface; the core was removed, and the sample was bagged, and later oven dried for 24 hours at $105^{\circ} \mathrm{C}$ and weighed in the laboratory to calculate the soil bulk density.

Field saturated hydraulic conductivity was measured after logging near the postlogging bulk density sample locations using a dual head infiltrometer (Reynolds and Elrick, 1990, Decagon Devices, Inc., Pullman, WA). The infiltrometer consisted of a ring which was inserted in the ground to a depth of $5 \mathrm{~cm}$. Pressure in the sealed chamber inside the ring was maintained at $5 \mathrm{~cm}$ and $10 \mathrm{~cm}$ total head for two cycles of 15 minutes each following a 15 minute wetting cycle.

Ground cover data along transects were collected with the same technique described in chapter two, using the same cover categories except that additional observations were used to classify if cover was in contact with the ground or suspended over the ground (aerial ground cover). This resulted in three additional classes: aerial ground litter, aerial ground vegetation, and aerial ground wood. The ground cover underlying any of the aerial ground classes was also recorded. Two separate cover 
categories were calculated: "interception cover", all ground and aerial ground cover that would intercept rainfall, and "surface cover", which was only the ground cover in contact with the soil surface. Post-fire cover measurements were made in all swales before logging in August 2014, in May 2015 following salvage in Triple A and before salvage in either Femmons unit, in July 2015 following salvage in the Lower Femmons unit, and in all swales in May 2016 following salvage.

Rills (Figure 3.4G, H) were mapped following logging using the same survey technique outlined in section 2.3, with the addition that each rill was also classified by initiation point in either one of the disturbance categories or as untrafficked. Rills were mapped in spring 2015 in Triple A, and spring 2016 in Lower and Upper Femmons, and again in ASW 3 in spring 2016 following subsoiling.

Ground cover was measured in each disturbance class using a 100 point grid. Three cover grids were randomly chosen in each disturbance class per swale, with the exception of feller buncher tracks in FSW 10 and low traffic skid trails in FSW 13, where the minimal disturbance footprint only allowed two cover grids. Disturbance cover was averaged across the three grids for each year.

Precipitation was recorded near each swale using a tipping bucket rain gage Rainwise, Inc, Trenton, ME) coupled to a HOBO data logger (Onset Computer Corporation, Bourne, MA). Three gages were installed in Triple A, two in Lower Femmons, and two in Upper Femmons (Figure 3.3). Precipitation events were separated by six hours of no rainfall, and the total accumulation, duration, and maximum 10 minute, 30 minute, and 60 minute rainfall intensities $\left(\mathrm{I}_{10}, \mathrm{I}_{30}\right.$, and $\mathrm{I}_{60}$ respectively) were calculated for each event. Precipitation data from the nearest rain gage was used for each swale. In cases where rain gages stopped working, the next closest rain gage was used. The rain gages at ASW 1, FSW 10, and FSW 12/13 and stage data from ASW 1, FSW 9, and FSW 13, the most responsive swales to rainfall in each unit, were used to determine which individual storms produced measurable runoff at the swale outlets.

Sediment was removed from silt fences approximately ten times. During the spring, summer, and fall seasons, sediment was removed after each runoff producing rain event; during the winter, multiple rain events occurred before fences could be accessed 
and emptied. Sediment was removed from fences and processed as described in section 2.3.

\subsection{Statistical methods}

All statistical analysis was done in the R software (R Core Team, 2016) using a significance level of 0.05 . Linear mixed effect models were developed using the lme4 package (Bates et al., 2014). For all models, normality and homogeneity were assessed by quantile-quantile plots and by plotting the residuals against predicted values; models met the standard assumptions (Winters, 2013). Fixed effect significance was assessed with an F-test using the Kenward-Roger approximation to the denominator degrees of freedom (Halekoh and Højsgaard, 2014) with the Anova function from the car package (Fox and Weisberg, 2011), which utilizes multiple model comparisons with fixed effect removals to determine significance. Coefficients of determination $\left(\mathrm{r}^{2}\right)$ for the marginal (fixed effects) and conditional (fixed effects and random effects combined) were calculated with the MuMIn package (Barton, 2016). The lsmeans package (Lenth, 2016) was used to compare fixed effects and fixed-covariate interactions in all models, with a Tukey adjustment. For all comparisons that involved measures over more than a single year, year or water year were treated as factors, in order to facilitate comparisons by period (Duursma and Powell, 2016).

The general form of the models used for comparisons was the response variable modeled by disturbance class or treatment (fixed effects), with year and logging status (pre or post salvage) used as fixed effect factors for measurements made over multiple dates, and swale or unit as the random effect, depending on the number of observations (Table 3.2). Field saturated hydraulic conductivity rates were $\log _{10}$ transformed to normalize residuals. At the swale scale, interception and surface ground cover were compared for 2014, 2015, and 2016. Surface ground cover within disturbed areas was compared for both 2015 and 2016.

Rill densities were square root transformed to normalize residuals, and compared by treatment with Unit as a random effect (Table 3.2). We then modeled the response of rill density to a covariate and an interaction between the covariate and treatment. Models relating rill density to logging disturbance were built using the subset of only the logged 
swale data. Covariates used in the model were total surface cover, total interception cover, surface wood, litter, vegetation and rock cover, the number of connected rills, channel density, and the mean swale slope (Table 3.2). For the logged swales, covariates were the percent area for each disturbance class, the number of waterbars in each swale, and the distance from waterbar outlets to the swale outlet (Table 3.2).

Sediment yields were summed by water year (1 October -30 September), $\log _{10}$ transformed to normalize residuals, and compared using an interaction between water year, treatment, and unit, with swale as the random effect (Table 3.2). We then modeled the response of sediment yield for the two fixed effects of treatment and water year and a single covariate, with interactions among the variable, treatment, and water year. Covariates used were the same used in the rill density model, with the addition of total rill length and rill density (Table 3.2). Models relating sediment yield to logging disturbance were built using a subset of only the logged swale data.

Simple linear regression was used to model the number of stumps in logged swales to the total area disturbed by skidding in each swale. The mean rill length to swale outlet was compared across disturbance classes using analysis of variance and multiple group comparisons with a Tukey adjustment.

\subsection{Results}

\section{Harvest intensity}

Logging resulted in 20-162 stumps ha ${ }^{-1}$ in logged swales, and a mean stump diameter of $53 \mathrm{~cm}$ with a standard deviation of $21 \mathrm{~cm}$ (Table 3.1, Figure 3.6). The linear regression of total percent area skid trails versus stumps $\mathrm{ha}^{-1}$ indicated stumps ha ${ }^{-1}$ explained $17 \%$ of the combined high and low traffic skid trails in logged swales $(\mathrm{p}=$ 0.27). FSW 13 in Upper Femmons had the lowest stumps ha ${ }^{-1}$ measurement of 20, and $9 \%$ total area in skid trails, making it the least intensively logged swale. FSW 9 had 162 stumps ha ${ }^{-1}$, making it the most intensively logged swale; however skidding operations were confined to one main skid trail covering only $15 \%$ of the swale.

\section{Logging disturbance}

Total ground disturbance from logging equipment ranged from $9-56 \%$ in logged swales with a mean of $31 \%$ and standard deviation of $15 \%$ (Figure 3.7). Feller buncher 
tracks represented the lowest amount of soil disturbance with a mean of just $2 \%$, but some feller buncher tracks were later used by skidders. Mixed traffic disturbance averaged just 7\%, and was only present in five of nine logged swales. Logging soil disturbance was dominated by skidding traffic. Low traffic skid trails ranged from $0-14 \%$ disturbance of swales, with a mean of $6 \%$. High traffic skid trails appeared in each logged swale and were the most prevalent soil disturbance class (9-29\%), averaging $17 \%$ across logged swales. Detailed individual swale disturbance data are available in Appendix E.

Mixed traffic disturbance and low traffic skid trails were typically observed branching off of high traffic skid trails (Figure 3.8). In some cases mixed disturbance areas were part of log landings. Many of the high traffic skid trails had waterbars to divert water off of skid trails as a best management practice. There were 2-4 waterbars installed on skid trails per swale.

\section{Soil bulk density}

Following logging, untrafficked areas had mean soil bulk densities of $1.16 \mathrm{~g} \mathrm{~cm}^{-3}$ at the $0-5 \mathrm{~cm}$ depth and $1.23 \mathrm{~g} \mathrm{~cm}^{-3}$ at the $5-10 \mathrm{~cm}$ depth (Figure 3.9). Mean soil bulk density at the $0-5 \mathrm{~cm}$ depth in the high traffic skid trails was $1.31 \mathrm{~g} \mathrm{~cm}^{-3}$ and was significantly higher than the untrafficked areas $(\mathrm{p}=0.03, \mathrm{n}=41)$. At the $5-10 \mathrm{~cm}$ depth, untrafficked areas had a significantly lower mean soil bulk density $\left(1.23 \mathrm{~g} \mathrm{~cm}^{-3}\right)$ than the mixed traffic $\left(1.41 \mathrm{~g} \mathrm{~cm}^{-3}, \mathrm{p}=0.01, \mathrm{n}=42\right)$ and high traffic skid trails $\left(1.44 \mathrm{~g} \mathrm{~cm}^{-3}, \mathrm{p}=\right.$ $<0.0001, \mathrm{n}=42$ ). Mean bulk density in the feller buncher tracks was also significantly lower than the bulk density in the high traffic skid trails at the $5-10 \mathrm{~cm}$ depth $\left(1.34 \mathrm{~g} \mathrm{~cm}^{-}\right.$ ${ }^{3}, \mathrm{p}=0.02, \mathrm{n}=42$ ). Bulk density values by swale and disturbance class are available in Appendix F.

Field saturated hydraulic conductivity

Field saturated hydraulic conductivity in untrafficked soil averaged $0.0103 \mathrm{~cm} \mathrm{~s}^{-}$

${ }^{1}$, while conductivity in the feller buncher tracks, mixed traffic, low traffic skid trails and high traffic skid trails averaged $0.0023,0.0016,0.0035$, and $0.0007 \mathrm{~cm} \mathrm{~s}^{-1}$, respectively (Figure 3.10). The mean field saturated conductivity rate in untrafficked soil was significantly different from the conductivities in all other disturbance classes $(n=45)$. The high traffic skid trails had significantly lower mean field saturated hydraulic 
conductivities than feller buncher tracks and low traffic skid trails, but not the mixed disturbance areas. Field saturated hydraulic conductivity values by swale and disturbance class are available in Appendix G.

$\underline{\text { Swale surface and interception cover }}$

In 2014, prior to any logging, interception cover averaged $39 \%$ and surface cover averaged $26 \%$, and there was no significant difference between controls and swales designated to be logged (Figure 3.11, 3.12). There were also no differences in litter, vegetation, wood or rock cover for either the surface or interception cover in 2014. In 2015 in Triple A, following salvage, logged swales had an average of $23 \%$ more surface cover than control swales, which was close to significantly different $(p=0.07)$. There was no significant difference in interception cover in Triple A for 2015. Neither cover type was significantly different between treatments in 2016. In Lower Femmons, there were no significant differences between treatments for both total interception and total surface cover before or after logging in 2015, although post-salvage logged swales had an average of $10 \%$ more surface cover. There were no significant differences in either interception and surface cover between logged and unlogged swales in Lower Femmons in 2016. In Upper Femmons, there were no significant differences in either interception or surface cover between logged and unlogged swales in 2015, nor after logging in 2016. The logged swale in Upper Femmons averaged approximately $4 \%$ less cover than the control swales in 2016. Across all logging units, in 2016, Upper Femmons had the highest mean bare soil in both the control (75\%) and the logged swales (53\%). Yearly swale surface and interception cover data are presented in Appendix I.

After logging, there were no significant differences in surface litter, vegetation, or rock cover between treatments in any of the three units. However, logging did have a significant effect on wood cover. In the 2015 post-salvage survey in Triple A, logged swales had an average of $14 \%$ more wood cover than control swales $(p<0.0001)$ (Figure 3.12A). However, by 2016, tree fall was observed along the bottom transect of both Triple A control swales and the difference was no longer significant. Following logging in May 2015, logged swales in Lower Femmons had a significantly higher mean wood cover than the control swale ( $9 \%$ difference, $\mathrm{p}=0.003)$, and the significant difference 
persisted in 2016 (Figure 3.12B). The difference in post-salvage wood cover between the logged and control swales in Upper Femmons was also significant $(p=0.02)$. The Upper Femmons logged swale had a mean of $8 \%$ more wood cover than the control swales (Figure 3.12C).

$\underline{\text { Logging disturbance class surface cover }}$

In both years surface cover generally decreased with increasing traffic intensity, and there was high variability in surface cover both between and within disturbance classes (Figure 3.13A). Surface cover in 2015 was dominated by litter with a range of 23 - $63 \%$ across all classes. The exception was mixed traffic areas which had a mean of $25 \%$ wood cover in addition to $29 \%$ litter. Total surface cover in untrafficked areas was the highest with a mean of $65 \%$ in 2015 , while high traffic skid trails were lowest with a mean of $32 \%$ (Figure 3.13B). Vegetative surface cover averaged only $0-10 \%$ across all disturbance classes, as the majority of vegetation was not in contact with the soil surface.

By 2016, vegetative surface cover had increased substantially in untrafficked areas to a mean of $42 \%$, while within the other disturbance classes vegetation only ranged from $3-22 \%$. Logging disturbed areas ranged from $8-29 \%$ mean wood cover, while untrafficked areas only had a mean of 5\%. The difference can be attributed to slash from harvesting activities. Average litter cover decreased in every class from 2015 to 2016, with the largest decrease of $50 \%$ occurring in untrafficked areas. This decrease is likely due to litter being covered up by increasing vegetative cover. Untrafficked areas again had the highest mean surface cover (61\%), while the high traffic skid trails were the lowest (28\%) (Figure 3.13B). Disturbance class surface cover data are available by class, swale, and year in Appendix $\mathrm{H}$.

In 2015, the second year after the fire, the mean surface cover was significantly higher in untrafficked and mixed traffic areas than in the high traffic skid trails (Figure 3.13B). Among the feller buncher tracks, low traffic skid trails, mixed traffic, and untrafficked areas there were no significant differences in surface cover. High traffic skid trails did not significantly differ from the feller buncher tracks or low traffic skid trails for surface cover. In 2016, ground cover in untrafficked areas was significantly higher than in the low traffic and high traffic skid trails, including those that were subsoiled. 
Mixed traffic areas again had higher ground cover than the high traffic skid trails, in addition to those that were subsoiled. Surface cover in the subsoiled skid trails was also significantly lower than the low traffic skid trails and feller buncher tracks, but was not significantly different from surface cover in the high traffic skid trails.

\section{Precipitation}

The study was conducted during a long-term drought in California characterized by low rainfall and snowfall accumulation and few large storms. The 2015 water year was especially dry, while 2016 had increased rainfall relative to 2015 (Figure 3.14, 3.15). The winter of 2015-2016 was an El Niño year, which is typically characterized by an elevated precipitation regime in the western US. Precipitation for the 2015-2016 winter in the Rim Fire was characterized by more frequent and longer duration events. The mean $\mathrm{I}_{10}, \mathrm{I}_{30}$, and $\mathrm{I}_{60}$ for all precipitation events for the 2016 water year were approximately 1 $\mathrm{mm} \mathrm{hr}{ }^{-1}$ less than in water year 2015 .

Precipitation at the ASW 1 rain gage totaled $265 \mathrm{~mm}$ for water year 2015, and this came in 31 separate precipitation events, including two large events in February 2015. For the 2016 water year, precipitation totaled $867 \mathrm{~mm}$ at the ASW 1 rain gage, and 1012 $\mathrm{mm}$ at the ASW 4/5 rain gage. The majority of precipitation during water year 2016 occurred during the winter months of November through March, with the exception of February, when only 43-48 mm of precipitation was recorded (Figure 3.15). Each month the ASW 4/5 rain gage recorded slightly more precipitation than the ASW 1 rain gage. The ASW 1 rain gage recorded 65 separate rain events, while ASW 4/5 recorded 72.

In Lower Femmons, the FSW 11 rain gage, which was installed in July 2015, recorded only a trace amount of precipitation in July $(<1 \mathrm{~mm})$ for the 2015 water year. Through the end of May for the 2016 water year, 1,101 mm of precipitation was recorded at FSW 10, and 1,172 $\mathrm{mm}$ at FSW 11, falling mostly throughout the winter months of November through March (Figure 3.15). 56 and 61 separate rain events occurred at FSW 10 and FSW 11, respectively. Similar to the Triple A rain gages, less precipitation was recorded in February 2016 (47 -50 mm).

The Upper Femmons rain gages at FSW 12/13 and FSW 14, which were installed in November 2015, recorded similar patterns in precipitation as were recorded in Triple A 
and Lower Femmons in the 2016 water year (Figure 3.15). FSW 12/13 received $877 \mathrm{~mm}$ of precipitation, while FSW 14 received 943 mm. FSW 12/13 recorded 47 separate rain events, while FSW 14 recorded 52 rain events. Complete precipitation data by rain gage and event are available in Appendix J.

Individual precipitation events occurred throughout each year, but were more frequent during the winter months. During the 2015 water year in Triple A the $\mathrm{I}_{60}$ ranged from 0.3 to $15 \mathrm{~mm} \mathrm{hr}^{-1}$, while the total event rainfall ranged from 0.3 to $50 \mathrm{~mm}$ (Figure 3.16). The maximum $\mathrm{I}_{60}$ of $15 \mathrm{~mm} \mathrm{hr}^{-1}$ occurred in February 2015, approximately one month after logging. In 2016 in Triple A, the $\mathrm{I}_{60}$ ranged from 0.3 to $13 \mathrm{~mm} \mathrm{hr}^{-1}$, while the total event rainfall ranged from 0.3 to $113 \mathrm{~mm}$. In Lower Femmons in 2016 the $\mathrm{I}_{60}$ ranged from 0.3 to $11 \mathrm{~mm} \mathrm{hr}^{-1}$ with an event rainfall range of 0.3 to $189 \mathrm{~mm}$ (Figure 3.16). In Upper Femmons, the $2016 \mathrm{I}_{60}$ for precipitation events ranged from 0.3 to $12 \mathrm{~mm} \mathrm{hr}^{-1}$, and the event rainfall ranged from 0.3 to $180 \mathrm{~mm}$ (Figure 3.16).

The storms that produced runoff and sediment in the logged swales in 2015 had mean $\mathrm{I}_{10}, \mathrm{I}_{30}$, and $\mathrm{I}_{60}$ values of $15 \mathrm{~mm} \mathrm{hr}^{-1}, 10 \mathrm{~mm} \mathrm{hr}^{-1}$, and $8 \mathrm{~mm} \mathrm{hr}^{-1}$, respectively (Figure $3.17 \mathrm{~A}, \mathrm{~B}, \mathrm{C}$ ). In the wetter 2016, the values were $12 \mathrm{~mm} \mathrm{hr}^{-1}, 8 \mathrm{~mm} \mathrm{hr}^{-1}$, and 7 $\mathrm{mm} \mathrm{hr}^{-1}$ (Figure $3.17 \mathrm{~A}, \mathrm{~B}, \mathrm{C}$ ). Runoff producing storms averaged $19 \mathrm{~mm}$ of precipitation in 2015, and had a mean duration of 12 hours, and in 2016 averaged $37 \mathrm{~mm}$ of precipitation and 18 hours in duration (Figure 3.17 D, E).

\section{$\underline{\text { Rills }}$}

Overland flow caused rills to form in all 14 swales regardless of treatment. In the Triple A control swales, rills formed on bare hillslopes, connecting to the outlet either directly or via an ephemeral channel (Figure 3.18). Rills in the logged swales typically initiated in disturbed areas on the hillslopes, most often within high traffic skid trails (Figure 3.18). Rills in high traffic skid trails were typically diverted downslope off the skid trail at waterbars, and often reached the outlets. Rills from low traffic skid trails and feller buncher tracks connected to the outlet most often when the disturbance features were in close proximity to an ephemeral channel or the swale outlet. In ASW 4, several rills formed in logging disturbance in the upper portions of the swale, however each rill crossed into and ended in a large undisturbed area in the middle of the swale that was 
densely vegetated (Figure 3.18, 3.19A). Following subsoiling in ASW 3, rills formed in the ripped high traffic skid trails, including several deep rills within furrows (Figure 3.20). The skid trails in ASW 3 were not parallel to the contour, and as such, the subsoiling was also not parallel to the contour.

In Lower Femmons, rill networks formed in a similar fashion to Triple A (Figure 3.21). FSW 8, the control swale, formed parallel rills on the lower bare hillslope that connected directly to the outlet, while intermittent rills formed upslope that later disappeared in dense vegetation or stump holes (Figure 3.19B). In FSW 9 and 10, rill patterns were similar to those observed in Triple A; rills formed in high traffic skid trails, were redirected downslope off of skid trails at waterbars and areas of low surface cover, and connected to the outlet. Logging disturbance in close proximity to the outlet formed and directly contributed rills to the outlet in both FSW 9 and 11. FSW 11 formed several rills upslope, however they all crossed into dense vegetation downslope before reaching the outlet.

In Upper Femmons, the logged swale FSW 13 formed several rills in untrafficked bare soil that connected via an ephemeral channel. Rills from skid trails and waterbars connected to the outlet when in close proximity to the ephemeral channel, and otherwise infiltrated upslope in FSW 13. The control swales in Upper Femmons were characterized by rills forming on bare hillslopes that connected to ephemeral channels and reached the outlet (Figure 3.21).

Rill densities in control swales ranged from $3.1-16 \mathrm{~cm} \mathrm{~m}^{-2}$ with a mean of $7.9 \mathrm{~cm}$ $\mathrm{m}^{-2}$ (Figure 3.22). In the logged swales, densities ranged from $0.35-22 \mathrm{~cm} \mathrm{~m}^{-2}$ and had a mean of $8.9 \mathrm{~cm} \mathrm{~m}^{-2}$. Channel densities across treatments ranged from $0.8-2.0 \mathrm{~cm} \mathrm{~m}^{-2}$, and were present in six of nine logged swales and three of five controls. Channels were found in swales with highly convergent hillslopes, and logging did not affect the presence of channels.

Rill density in ASW 3 increased from $11 \mathrm{~cm} \mathrm{~m}^{-2}$ to $15 \mathrm{~cm} \mathrm{~m}^{-2}$ following subsoiling in fall 2015. Subsoiling in the skid trails removed existing rills, and during the winter of 2015-2016, new rills developed in furrows which were concentrated and directed downslope at waterbars. 
All rills in control swales initiated in untrafficked bare soil, while this disturbance class contributed only $0-66 \%$ of the rill network in logged swales (Figure 3.22). The rills within logged swales typically were a mix of rills from untrafficked soil and high traffic skid trails. Rills initiating in high traffic skid trails contributed a mean of $5.7 \mathrm{~cm} \mathrm{~m}^{-2}$ in logged swales, and constituted anywhere from $0-89 \%$ of the total rill density (Figure 3.22). Control swales had between 4-18 rills that reached the outlet, while logged swales had 0-15 rills from untrafficked areas and 1-12 rills from logging disturbance that reached the outlet (Figure 3.23). Complete individual rill data by swale are included in Appendix K.

The rill length to the outlet also varied by the disturbance type at the rill initiation point. Rills from untrafficked soil had a mean length to outlet of $32 \mathrm{~m}$ (Figure 3.24). Rills from feller buncher tracks averaged $19 \mathrm{~m}$, while rills initiating in mixed traffic areas had a mean of $26 \mathrm{~m}$. Low traffic skid trail rills averaged $39 \mathrm{~m}$ from initiation point to the outlet, while rills initiated in high traffic skids had a mean length to the outlet of $49 \mathrm{~m}$. One rill in ASW 1 initiated from the upper area of the skid trail in that swale (Figure 3.18), and this is visible in the cluster at around $100 \mathrm{~m}$ in the high traffic skid trail category in Figure 3.24; the rest of the rills in this cluster of points are from FSW 13 in Upper Femmons. The mean rill lengths for rills initiating in untrafficked soil and feller buncher tracks were significantly different than the lengths of rills initiating in high traffic skid trails.

The model result was that there was no significant difference in rill densities between control and logged swales. For all predictors, the marginal and conditional $\mathrm{r}^{2}$ values were the same, as unit had almost no effect on rill density (Table 3.3). The total interception cover was the only significant cover predictor $(p=0.04)$ and explained $34 \%$ of the variance. Surface wood cover was not a significant predictor, despite logging significantly elevating wood cover in the swales. The only variable that had a significant interaction with treatment was mean swale slope $(p=0.047)$. The response in controls was a 0.271 unit increase in rill density for every one percent increase in mean slope, while in logged swales rill density decreased 0.103 units for each percent increase in slope. One explanation for this result may be that the logged swales with lower slopes 
were easier to operate equipment on which led to more extensive skid trails, which in turn initiated rills. ASW 3 had 21\% high traffic skid trails, the second highest percentage in Triple A, and the lowest mean slope (15\%). However, $76 \%$ of the rill network in ASW 3 was initiated by skid trails, and the rill density was the second highest of the logged swales in Triple A.

The strongest predictor of rill density within the logged swales was the distance from the waterbar outlet to the swale outlet; the marginal and conditional $r^{2}$ was 0.55 , and the effect was significant $(p=0.03)$, with a slope coefficient of -0.05 . The number of waterbars in each swale was also a significant predictor of rill density $(p=0.045)$ and explained $50 \%$ of the variance; rill density increased 1.16 units per waterbar. Total disturbance was not significant and only explained $7 \%$ of the variance. The percent area of high traffic skid trails explained $43 \%$ of the marginal and conditional variance and was nearly significant as a predictor of rill density $(\mathrm{p}=0.056)$. Other disturbance classes had no significant effect on rill density, and this may be due to the wide range of variability in presence and percent cover of the other classes.

\section{Sediment yield}

During the 2015 water year in Triple A, the average sediment yield in the control swales was $4.3 \mathrm{Mg} \mathrm{ha}^{-1}$, with a range of 1.8-6.8 $\mathrm{Mg} \mathrm{ha}^{-1}$ (Figure 3.25A). The logged swales had a mean sediment yield of $3.0 \mathrm{Mg} \mathrm{ha}^{-1}$, and a range of 0.3-8.1 $\mathrm{Mg} \mathrm{ha}^{-1}$ (Figure 3.25A), and the difference between treatments was not significant. A majority of the recorded sediment yields for 2015 occurred during February 2015 during a high intensity $\left(\mathrm{I}_{60}=15 \mathrm{~mm} \mathrm{hr}^{-1}\right)$ precipitation event that occurred approximately one month after logging (Figure 3.16). For the 2016 water year, mean sediment yield in the Triple A controls was $0.9 \mathrm{Mg} \mathrm{ha}^{-1}$, while the logged swales averaged $1.1 \mathrm{Mg} \mathrm{ha}^{-1}$, and this difference was not significant (Figure 3.25B). Each swale except the subsoiled ASW 3 produced less sediment in water year 2016 than water year 2015. In the other swales, despite the increased number of precipitation events and total precipitation amount relative to water year 2015, sediment yield decreased.

Fences were installed in Lower Femmons in July 2015, and no sediment was produced between that date and the end of the water year. In Lower Femmons, the 
sediment yield in the control swale was $0.1 \mathrm{Mg} \mathrm{ha}^{-1}$ for the 2016 water year, while the logged swales averaged 1.1 $\mathrm{Mg} \mathrm{ha}^{-1}$ (0-2.7 $\mathrm{Mg} \mathrm{ha}^{-1}$ range) (Figure 3.25C). In Upper Femmons the two control swales averaged $11.8 \mathrm{Mg} \mathrm{ha}^{-1}$ while the logged swale had a sediment yield of $3.2 \mathrm{Mg} \mathrm{ha}^{-1}$ (Figure 3.25D), and the difference in treatments was not significant. The 2016 mean sediment yield of the Upper Femmons control swales was much higher than both the Triple A and Lower Femmons control swales. Additionally, the logged swale in Upper Femmons produced the highest sediment yield of all logged swales for water year 2016. Complete annual sediment yield data are included in Appendix L.

Statistical model results indicated that none of the cover variables were significant predictors of sediment yield regardless of treatment or water year (Table 3.4). The total surface cover explained $23 \%$ of the marginal variance $(p=0.11)$, while the total interception cover explained $20 \%$ of the marginal variance $(p=0.23)$. Surface vegetation was a nearly significant predictor of sediment yield $\left(\mathrm{p}=0.08\right.$; marginal $\mathrm{r}^{2}=0.20$, conditional $\left.r^{2}=0.88\right)$, as was surface rock cover $\left(p=0.07\right.$; marginal $r^{2}=0.36$, conditional $\left.r^{2}=0.74\right)$; surface rock cover was a positive covariate with sediment yield.

The rill density $\left(\mathrm{p}=0.004\right.$; marginal $\mathrm{r}^{2}=0.34$, conditional $\left.\mathrm{r}^{2}=0.85\right)$, was a highly significant predictor of sediment yields. Rill density explained $34 \%$ of the marginal variance in sediment yields $85 \%$ of the conditional variance in sediment yields. Sediment yield increased as rill density increased for both the 2015 and 2016 water year (Figure $3.25 \mathrm{E})$. The sum of the rill lengths was a significant predictor of sediment yields $(\mathrm{p}=$ 0.02 ; marginal $r^{2}=0.54$, conditional $r^{2}=0.76$ ). In the logged swales none of the disturbance variables were significant predictors. The highest marginal $r^{2}$ was for the number of waterbars $\left(\mathrm{r}^{2}=0.24 ; \mathrm{p}=0.27\right)$, followed by the distance from the waterbar outlet to the swale outlet $\left(\mathrm{r}^{2}=0.22 ; \mathrm{p}=0.36\right)$.

\subsection{Discussion}

Ground cover, soil bulk density, and the field saturated hydraulic conductivity rates within catchments can be crucial factors to the initiation of rill erosion, and the results of this study support past results of the effect of salvage logging on these factors. Several studies have concluded that increasing traffic levels of logging equipment, 
especially log skidders, results in decreased ground cover, increased soil bulk density, and decreased infiltration rates (Croke et al., 2001, Wagenbrener et al., 2015, Wagenbrenner et al., 2016). In the logged swales, increased soil bulk density and decreased surface cover and field saturated hydraulic conductivity in disturbed areas generated runoff, which initiated rills more often than within untrafficked areas.

While the Rim Fire swales indicated that the effects of logging disturbance can reduce surface cover at the scale of a few meters, the effect on ground cover was insignificant at the swale scale. Wagenbrenner et al. (2015) also found that logging did not have a direct effect on ground cover at the swale scale in several sites in the western US. The lack of an effect at the swale scale may be due to logging disturbance not being extensive enough in some swales to register a significant difference between treatments, in particular the swales logged less intensively at later dates. Bare ground due to logging disturbance was likely often covered by the high amount of wood cover from harvest activity in logged swales. In regards to lasting effects over time, not just the two years of surveys in our study, Peterson and Dodson (2016) found that in one northeastern Oregon site, salvage logging had no lasting impact to understory vegetation.

Past research indicated that increases in wood cover as a result of salvage logging may help mitigate soil loss following the cumulative impact of wildfire and post-fire salvage disturbance (Poff, 1989, Wagenbrenner et al., 2015). The pulse of wood debris following salvage logging in this study is in line with similar past findings (Donato et al., 2006, Peterson et al., 2015). Wood contributed to higher surface cover in logged swales than controls, however the difference in surface cover between treatments was not significant. Neither the amount of wood cover nor the total surface cover had a significant effect on either rill formation or sediment yield.

In our study swales, even three years post-fire in 2016, bare soil in logged and control swales still averaged $48 \%$ and $58 \%$, respectively, despite the increase in surface cover from wood. Berg et al. (2010) found that plots with rills in recently burned forests had a median of $53 \%$ bare soil, similar to our cover values.

Our lack of significant difference in mean rill density and sediment yields between treatments indicates that the resulting wood cover from logging was not 
effective at mitigating erosion. Wagenbrenner et al. (2016) found that adding slash to areas disturbed by logging equipment had no effect on sediment flux in simulated rill experiments; their study noted that wood may not be in effective contact with the soil surface, allowing runoff to undercut or circumnavigate slash. An alternate theory is that the relative impact of wood cover on sediment storage capacity may be minimal, which could lead to the maximum capacity being reached during the first runoff producing precipitation events following logging.

The wood cover in logged swales in our study was typically clustered near where trees had been felled and skidded, and was therefore relatively patchy across the swale. Patchy cover with as little as $25 \%$ wood cover downslope of runoff was found to significantly reduce erosion rates following prescribed fire (Harrison et al., 2016). While wood may increase the surface roughness, which can directly reduce erosion, the spatial location of wood is important. Ensuring that wood covers and is downslope of bare patches of soil may help to increase the overall effectiveness of adding wood slash to reduce rill erosion and sediment yields from post-fire salvaged areas.

Logging disturbances located near areas of high vegetative cover and natural sediment sinks such as stump holes were less likely to be connected and deliver sediment to the outlet. The lack of significant correlation between sediment yield and percent area disturbed alone indicates that there was an important spatial component to disturbance in logged swales. Large undisturbed areas and areas of high surface cover below some of the logging disturbances, in particular concentrated dense wood cover, allowed sediment deposition to occur before reaching outlets or ephemeral channels (see mapped examples in ASW 4 and FSW 11, and upper portions of FSW 13, Figures 3.18, 3.21).

Proximity of logging disturbance to features such as ephemeral channels, bare soil, areas of low post-fire vegetative recovery, and other logging disturbances generally enhanced rill connectivity and sediment delivery to the outlet. For example, rills from skidding disturbance and waterbars near ephemeral channels in ASW 1, ASW 5, and FSW 13 were connected to outlets due in part to their proximity to the channels. FSW 9, which averaged $48 \%$ bare soil in untrafficked areas following logging, exemplifies the connectedness of rills that initiated in high traffic skid trails passing through areas of low 
vegetative recovery to connect to the swale outlet. In contrast, FSW 11 and its 19\% bare soil within untrafficked areas following logging, and had no rills from high traffic skid trails reach the swale outlet.

The Rim Fire Environmental Impact Statement (USDA, 2014) required an entire logging unit to be less than $15 \%$ skid trails. In our study, several individual swales had $15 \%$ or more area in high traffic skid trails with differing responses in sediment yield. ASW 5 in the Triple A unit was $28 \%$ high traffic skid trails, had a rill density of $22 \mathrm{~cm} \mathrm{~m}^{-}$ ${ }^{2}$, and produced the highest sediment yield in Triple A in $2015\left(8.1 \mathrm{Mg} \mathrm{ha}^{-1}\right)$. FSW 9, with high traffic skid trails in $15 \%$ of the swale, produced the most sediment in Lower Femmons for $2016\left(2.7 \mathrm{Mg} \mathrm{ha}^{-1}\right)$, with a rill density of $15 \mathrm{~cm} \mathrm{~m}^{-2}$. FSW 10, also in Lower Femmons, was $29 \%$ high traffic skid trails, with much of the disturbance in the upper portion of the swale, and not directly connected to the outlet. As such, FSW 10 developed a rill density of only $10 \mathrm{~cm} \mathrm{~m}^{-2}$, and had a cumulative sediment yield of only $0.5 \mathrm{Mg} \mathrm{ha}^{-1}$ for the 2016 water year. These examples indicate that it might be more reasonable to enforce a limit on skid trail footprint within individual catchments instead of across an entire harvest unit. Our results suggest that $15 \%$ or more area in high traffic skid trails would lead to relatively high rill network connectivity and sediment yields if the impacted area were above relatively uncovered areas, or if the disturbance was close to the channel.

Past research has noted that the spatial and location of skid trails in burned and logged areas can play an important role in determining sediment delivery (McIver and McNeil, 2006, Wagenbrenner et al., 2015), at both the swale (Wagenbrenner et al., 2015) and watershed scale (Silins et al., 2009). Within our study swales the spatial location of high traffic skid trails relative to channels and areas of low ground cover played an important component in connectivity and sediment yields, in addition to the percent area disturbed by high traffic skid trails.

In the linear mixed model, rill density in logged swales increased as the number of waterbars increased and when waterbars were in closer proximity to the outlet. Rills from high traffic skid trails that connected to swale outlets traveled a significantly longer distance than rills from burned and untrafficked portions of the swales, likely due to the 
low surface roughness along their flowpaths. Litschert and MacDonald (2009) found that skid trails and waterbars were the typical sources of sediment that reached streams and rivers in unburned harvest sites throughout the Sierra Nevada; in particular, they observed a lack of surface roughness downslope of waterbars, which encouraged rill formation and erosion. Approximately $56 \%$ of the waterbars within logged swales in our study directed rills downslope and allowed the rills to reach the outlet directly or by an ephemeral channel. The low surface cover in burned areas may contribute to the likelihood that rills diverted off of skid trails by waterbars reach downslope ephemeral channels and outlets, similar to the findings of Litschert and MacDonald (2009).

We are not implying that the use of waterbars as a best management practice (BMP) for post-fire logging should be discontinued. To the contrary, our results show that the lower surface cover, increased soil compaction, and reduced field saturated hydraulic conductivity rates within skid trails enhance runoff and erosion generation and reduce the likelihood of infiltration of surface runoff relative to undisturbed burned areas. Diverting runoff from the relatively smooth and impervious skid trails to the otherwise undisturbed recovering burned area may still allow rilling and sediment delivery to occur, but the undisturbed slopes impart less risk of rill incision and unhampered sediment delivery downstream. Our study indicates that the use of waterbars as a BMP in burned and logged areas requires consideration of waterbar placement in regards to downslope surface cover and proximity to ephemeral channels. Careful waterbar placement scales up to careful planning and consideration for the location and extent of high traffic skid trails relative to ephemeral channels and areas of low vegetative recovery in burned and logged catchments.

Because of the risk of significant post-fire erosion with even a single intense storm event, mitigating the effects of logging disturbances as potential runoff and erosion sources should be considered. Mulching may be an effective and economically justifiable option to reduce sediment loss in salvage logged areas (Robichaud et al., 2013, Fernandez and Vega, 2016), and in particular to reduce rill connectivity from high traffic skid trails and waterbars. 
Explicitly testing the effectiveness and impact of waterbars in burned and logged catchments was outside the scope of this study. These results are more indicative of the effects of the general operational techniques and BMP's implemented in each unit for the Rim Fire salvage operations. Future research should be designed to quantify the benefits of using waterbars as a post-fire salvage BMP and to determine the effective distance at which runoff from watearbars disperses and infiltrates on burned hillslopes. Further, given the relationship between waterbars and connectivity to the swale outlets, alternative designs to reduce this connectivity should be tested, such as: increased waterbar frequency or use of mulch or slash to protect waterbar outlets.

Subsoiling was another BMP used to mitigate the impacts from some skid trails, reducing soil compaction and increasing infiltration within skid trails. Skid trails in one swale, ASW 3, were subsoiled in September 2015 before the winter wet season began. The effect of subsoiling in this example was that following precipitation, the rills reformed within the furrows in the skid trail, were concentrated at the waterbars, and directed downslope where they connected to the outlet. The rill density increased for ASW 3, and ASW 3 was the only swale for which the sediment yield was higher in the 2016 than in 2015. Additionally, the new rills in the furrows appeared deeper and wider than the rills that were removed by subsoiling.

One explanation is that the subsoiling before the winter wet season resulted in extensive bare ground being exposed to relatively intense rainfall. Additionally, the furrows from subsoiling were not parallel to the slope, which allowed runoff to concentrate and have a direct downslope path, enhancing soil erosion because of the greater energy available. This single example highlights the need for careful implementation of subsoiling as a BMP. Future research specifically addressing the effectiveness of subsoiling as a BMP is needed, in order to ascertain the effects on sediment yields and the rate of success in salvage logged areas.

Rill density was a highly significant predictor of sediment yield, indicating that sediment yield and rill erosion on hillslopes were strongly related to each other. In both logged and unlogged swales, sediment yields increased as rill density increased. In this study we were able to identify sediment sources via rills, and that detail is of great value. 
We can make an inference of what the sediment sources were based on rill initiation points. Some unlogged and logged swales, such as ASW 1, FSW 12, and FSW 13 (Figures 3.18, 3.21), had several rills initiate in untrafficked bare soil and consistent sediment delivery during runoff events. The swales where the high traffic skid trails initiated rills and became sediment sources also had some of the highest sediment yields of logged swales within each unit (see ASW 3, ASW 5, and FSW 9, Figures 3.18, 3.21, 3.25A, 3.25C). Skid trails can increase rill erosion (Chase, 2006) and have significantly higher sediment yields than burned and unlogged areas at the hillslope scale (Wagenbrenner et al., 2015). While sediment may be delivered from across the entire hillslope, our research suggests that certain rill and sediment sources on hillslopes, such as skid trails, can influence cumulative sediment yields in swales.

The timing of salvage logging in swales also may play a role in determining sediment yield, in addition to the extent of logging disturbance. Triple A, the first unit to be logged, received fewer precipitation events in water year 2015 than 2016. Large precipitation events in February 2015 produced most of the sediment in Triple A for 2015. Sediment yields in each swale were higher than during the more frequent and longer duration precipitation events of 2016 (with the exception of ASW 3, which was subsoiled). Kampf et al. (2016) found that sediment yields in burned areas correlated strongly with rainfall amounts where intensity exceeded $10 \mathrm{~mm} \mathrm{hr}^{-1}$. The February 2015 events had intensities of 15 and $11 \mathrm{~mm} \mathrm{hr}^{-1}$, and cumulative depths of 49 and $45 \mathrm{~mm}$, respectively. These two large precipitation events indicate that only one or two intense events are needed to produce significant erosion in both burned and burned and logged areas. In the case of Triple A, logging occurred just over one year post-fire, from November to December 2014. The approximate 14-month lag time resulted in extensive disturbed areas in a larger landscape of recovering burned hillslopes, and the secondary disturbance occurred just prior to the winter wet season. The year of recovery of the logging-disturbed areas and post-fire vegetative recovery in unlogged areas reduced sediment yields from 2015 to 2016 in Triple A despite increased precipitation in 2016. In 2016, the logged swales in both Triple A and Lower Femmons averaged 1.1 $\mathrm{Mg} \mathrm{ha}^{-1}$. Lower Femmons had several months of post-salvage recovery time before the 
winter wet season, in addition to the extra year of post-fire recovery, resulting in low sediment yields despite being logged that year. The timing of salvage logging, as with other cumulative effects (MacDonald, 2000), should be carefully assessed to minimize the impact from runoff generating rainfall. The impact of the timing of salvage logging on sediment yields is another area of needed study.

Because of market and wood conditions the logging intensity, which was correlated to percent disturbance, appeared to decrease over time since wildfire. Triple A averaged 36\% disturbance in logged swales, Lower Femmons 30\%, and Upper Femmons only $9 \%$. Upper Femmons had the lowest level of logging intensity (20 stumps ha ${ }^{-1}$ ), which was largely concentrated on the upper portion of the swale and on low slopes, while the steeper slopes in the swale were avoided (FSW 13).

Despite the low logging intensity, FSW 13 had the highest sediment yield of all the logged swales in 2016. Additionally, both the Upper Femmons controls had higher sediment yields than any other control swales in water year 2016. The high sediment yields in 2016 in the Upper Femmons unit can be explained by differences in cover, channelization, and soil properties. The controls averaged $75 \%$ bare soil, and the logged swale averaged 53\% percent bare soil, and these values were the highest rates of bare soil of all he swales in 2016. Each swale was also channelized, providing a direct flowpath to the outlet and a source of sediment.

Control swale FSW 12 developed an extensive rill network and had a narrow, steep contributing area, while adjacent logged swale FSW 13 had a much greater contributing area that included broad flat slopes in the upper swale. FSW 12 and FSW 13 both produced similar amounts of raw sediment, but in the context of contributing area, FSW 12 had a greater sediment yield. FSW 14 was similar in shape and topography to FSW 13, with the exception that the low-slope area at the top of FSW 14 was smaller than that of FSW 13. FSW 14 was instead almost entirely steep bare hillslopes with a deep centralized channel. These differences likely helped to contribute to a higher sediment yield relative to FSW 13.

The lack of significant difference in sediment yield at the catchment scale between logged and unlogged swales due to site to site variability echoes past research 
(Chou et al., 1994, Chase, 2006, Silins et al., 2009, Stone et al., 2014, Wagenbrenner et al., 2015). Our study indicated that salvage logging that occurs 1-2 years post-fire, in particular high traffic disturbance, can have negative impacts to soils, ground cover, and hydraulic conductivity at scales of a few meters. While these impacts do not scale up to the swale scale, they do help to explain the elevated number of rills initiated by high traffic disturbances. Additionally, specific features such as skid trails and waterbars may need additional mitigation in order to reduce rill networks and their resultant connectivity and delivery of sediment.

To effectively manage salvage logging in burned forests, individually assessing and managing each small catchment within a timber harvest area will help ensure that detrimental erosion does not occur. Incorporating larger areas of undisturbed ground downslope of logging disturbance and upslope of ephemeral channels will increase the spatial disconnectivity of logging disturbances. Increasing ground cover on skid trails to reduce the initiation of rills, and below waterbars to keep diverted rills from connecting to ephemeral channels, will help to ensure that post-fire salvage logging does not increase sediment yields. Land managers may be able to more effectively avoid any detrimental erosion due to logging activity, in particular skidding operations, by optimizing layout and the spatial extent of disturbances within individual catchments. Severely burned hillslopes with reduced recovery and more bare soil, relative to areas with more advanced recovery, should be treated with more care than areas with more advanced recovery. While this may take more effort, the extra effort will help to reduce any potential negative impacts from post-fire salvage logging.

\section{$\underline{3.7 \text { Conclusion }}$}

This study assessed the effects of post-fire salvage logging on factors controlling rill initiation, rill networks, and sediment yields for two years after logging. Increased levels of logging equipment traffic, in particular high traffic skid trails, locally reduced vegetative and total surface cover, increased soil bulk density, and decreased field saturated hydraulic conductivity relative to untrafficked areas. The amount of logging disturbance was highest in swales logged 14 months post-fire, and decreased in units logged at later dates. Logging did not significantly affect the mean ground cover, rill 
density, or sediment yields at the swale scale. However, logging resulted in significantly increased wood cover in logged swales. Rill density ranged from 0.35 to $22 \mathrm{~cm} \mathrm{~m}^{-2}$ in logged swales, and 2.2 to $16 \mathrm{~cm} \mathrm{~m}^{-2}$ in control swales. Sediment yields also had a wide range across treatments and swales in both the 2015 and 2016 water years. Sediment yields increased with rill density, and the two variables were highly correlated. Rills initiated on bare hillslopes in unlogged swales. In logged swales, rills also started on bare undisturbed areas, but more often initiated in high traffic skid trails. Rill that started in skid trails were usually concentrated at waterbars and connected to the swale outlet, increasing connectivity between hillslopes and channels. Rills from skid trails traveled longer distances to the outlet than rills from the other initiation categories. Within the logged swales, the percent area in high traffic skid trails was a nearly significant predictor of rill density, and the number of waterbars in each swale was a significant predictor of rill density. These results suggest that the spatial layout of high traffic skid trails is an important factor in determining the effect of logging on rilling and sediment delivery to channels. In order to further reduce the occurrence of rills and sediment from reaching the stream network, ground cover should be increased on and downslope of skid trails and waterbars outlets. 


\section{$\underline{\text { 3.8 Tables and Figures }}$}

Table 3.1: Rim Fire swale characteristics. Unit, treatment, approximate logging date, mean swale slope, slope range, and logging intensity for each swale.

\begin{tabular}{cccccc}
\hline Unit & Swale & Treatment & $\begin{array}{c}\text { Logging } \\
\text { Date }\end{array}$ & $\begin{array}{c}\text { Mean } \\
\text { Slope (\%) }\end{array}$ & $\begin{array}{c}\text { Stumps } \\
\text { ha }^{-1}\end{array}$ \\
\hline Triple A & 1 & Logged & Nov-Dec 2014 & 26 & 76 \\
Triple A & 2 & Control & Nov-Dec 2014 & 20 & 0 \\
Triple A & 3 & Logged & Nov-Dec 2014 & 15 & 84 \\
Triple A & 4 & Logged & Nov-Dec 2014 & 29 & 66 \\
Triple A & 5 & Logged & Nov-Dec 2014 & 24 & 126 \\
Triple A & 6 & Logged & Nov-Dec 2014 & 19 & 108 \\
Triple A & 7 & Control & Nov-Dec 2014 & 28 & 0 \\
& & & & & \\
Lower Femmons & 8 & Control & May 2015 & 19 & 0 \\
Lower Femmons & 9 & Logged & May 2015 & 22 & 162 \\
Lower Femmons & 10 & Logged & May 2015 & 15 & 95 \\
Lower Femmons & 11 & Logged & May 2015 & 27 & 82 \\
& & & & & \\
Upper Femmons & 12 & Control & September 2015 & 26 & 0 \\
Upper Femmons & 13 & Logged & September 2015 & 20 & 20 \\
Upper Femmons & 14 & Control & September 2015 & 20 & 0 \\
\hline
\end{tabular}


Table 3.2: Linear mixed model structure for Rim Fire measurements. Asterisks indicate interaction among the fixed effects.

\begin{tabular}{|c|c|c|}
\hline Response variable & Fixed effect or covariate & $\begin{array}{c}\text { Random } \\
\text { effect }\end{array}$ \\
\hline Bulk density & Disturbance class & $\begin{array}{c}\text { Swale nested } \\
\text { within Unit }\end{array}$ \\
\hline $\begin{array}{l}\text { Log transformed } \\
\text { field saturated } \\
\text { hydraulic } \\
\text { conductivity }\end{array}$ & Disturbance class & $\begin{array}{l}\text { Swale nested } \\
\text { within Unit }\end{array}$ \\
\hline $\begin{array}{c}\text { Disturbance surface } \\
\text { cover }\end{array}$ & Disturbance class $*$ Year & $\begin{array}{l}\text { Swale nested } \\
\text { within Unit }\end{array}$ \\
\hline $\begin{array}{l}\text { Swale interception } \\
\text { and surface cover }\end{array}$ & Treatment $*$ Unit $*$ Salvage status $*$ Year & Swale \\
\hline $\begin{array}{l}\text { Square root of rill } \\
\text { density }\end{array}$ & $\begin{array}{l}\text { Treatment * : } \\
\text { - Total surface cover, total interception } \\
\text { cover; surface wood, litter, vegetation, } \\
\text { and rock cover, number of rills; channel } \\
\text { density; mean swale slope } \\
\text { [Logged swales only]: Water Year* } \\
\text { - \% disturbance class } \\
\text { - Number of waterbars } \\
\text { - Waterbar distance from outlet }\end{array}$ & Unit \\
\hline $\begin{array}{l}\text { Log transformed } \\
\text { sediment yield }\end{array}$ & $\begin{array}{l}\text { Treatment * Water Year * : } \\
\text { - Total surface cover, total interception } \\
\text { cover; surface wood, litter, vegetation, } \\
\text { and rock cover; number of rills; total rill } \\
\text { length; channel density; rill density; mean } \\
\text { swale slope } \\
\text { [Logged swales only]: Water Year* } \\
\text { - \% disturbance class } \\
\text { - Number of waterbars } \\
\text { - Waterbar distance from outlet }\end{array}$ & $\begin{array}{l}\text { Swale nested } \\
\text { within Unit }\end{array}$ \\
\hline
\end{tabular}


Table 3.3: Linear mixed effects model results for rill density. N.S. stands for 'not significant" for the treatment interaction. Otherwise the slope coefficients for each treatment are listed.

\begin{tabular}{ccccc}
\hline Covariate & P value & $\begin{array}{c}\mathrm{r}^{2} \text { Marginal/ } \\
\text { Conditional }\end{array}$ & $\begin{array}{c}\text { Standard } \\
\text { error }\end{array}$ & $\begin{array}{c}\text { Treatment } \\
\text { Interaction }\end{array}$ \\
\hline Total surface cover \% & 0.17 & $0.22 / 0.22$ & 1.19 & N.S. \\
Total interception cover \% & 0.04 & $0.34 / 0.34$ & 1.08 & N.S. \\
Surface wood cover \% & 0.53 & $0.10 / 0.10$ & 1.30 & N.S. \\
Surface litter cover \% & 0.31 & $0.14 / 0.14$ & 1.27 & N.S. \\
Surface veg. cover \% & 0.16 & $0.17 / 0.17$ & 1.24 & N.S. \\
Surface rock cover \% & 0.96 & $0 / 0$ & 1.39 & N.S. \\
Number of rills & 0.15 & $0.26 / 0.26$ & 1.15 & N.S. \\
Channel density (cm m $^{-2}$ ) & 0.59 & $0.07 / 0.07$ & 1.33 & N.S \\
& & & & Significant \\
Mean slope \% & 0.73 & $0.31 / 0.31$ & 1.11 & Control=0.025 \\
& & & & Logged=-0.103 \\
Total disturbance \% & 0.53 & $0.07 / 0.07$ & 1.35 & - \\
High traffic skid trails \% & 0.056 & $0.43 / 0.43$ & 1.04 & - \\
Low traffic skid trails \% & 0.98 & $0 / 0$ & 1.41 & - \\
Total skid trail \% & 0.23 & $0.33 / 0.33$ & 1.13 & - \\
Feller buncher tracks \% & 0.73 & $0.04 / 0.04$ & 1.38 & - \\
Mixed traffic \% & 0.87 & $0 / 0$ & 1.41 & - \\
Number of waterbars & 0.045 & $0.50 / 0.50$ & 0.96 & - \\
Waterbar distance from & 0.032 & $0.55 / 0.55$ & 0.91 & - \\
swale outlet (m) & & & & \\
\hline
\end{tabular}


Table 3.4: Linear mixed effects model results for sediment yield. None of the interactions between water year and treatment were significant.

\begin{tabular}{cccc}
\hline Covariate & P value & $\begin{array}{c}\mathrm{r}^{2} \\
\text { Marginal/ } \\
\text { Conditional }\end{array}$ & $\begin{array}{c}\text { Standard } \\
\text { error }\end{array}$ \\
\hline Total surface cover \% & 0.11 & $0.23 / 0.76$ & 0.53 \\
Total interception cover \% & 0.23 & $0.20 / 0.75$ & 0.56 \\
Surface wood cover \% & 0.18 & $0.14 / 0.94$ & 0.28 \\
Surface litter cover \% & 0.14 & $0.29 / 0.58$ & 0.67 \\
Surface veg. cover \% & 0.08 & $0.20 / 0.88$ & 0.40 \\
Surface rock cover \% & 0.07 & $0.36 / 0.74$ & 0.52 \\
Number of rills & 0.08 & $0.35 / 0.80$ & 0.49 \\
Total rill length $(\mathrm{m})$ & 0.02 & $0.54 / 0.76$ & 0.49 \\
Channel density (cm m ${ }^{-2}$ ) & 0.23 & $0.32 / 0.80$ & 0.40 \\
Rill density (cm m ${ }^{-2}$ ) & 0.004 & $0.32 / 0.85$ & 0.49 \\
Mean slope \% & 0.68 & $0.18 / 0.45$ & 0.83 \\
Total disturbance \% & 0.93 & $0.12 / 0.80$ & 0.46 \\
High traffic skid trails \% & 0.39 & $0.19 / 0.63$ & 0.59 \\
Low traffic skid trails \% & 0.74 & $0.17 / 0.96$ & 0.28 \\
Total skid trail \% & 0.74 & $0.14 / 0.73$ & 0.51 \\
Feller buncher tracks \% & 0.49 & $0.18 / 0.65$ & 0.58 \\
Mixed traffic \% & 0.99 & $0.15 / 0.89$ & 0.33 \\
Number of waterbars & 0.27 & $0.24 / 0.68$ & 0.56 \\
Waterbar distance from & 0.36 & $0.22 / 0.67$ & 0.56 \\
swale outlet $(\mathrm{m})$ & & & \\
\hline
\end{tabular}




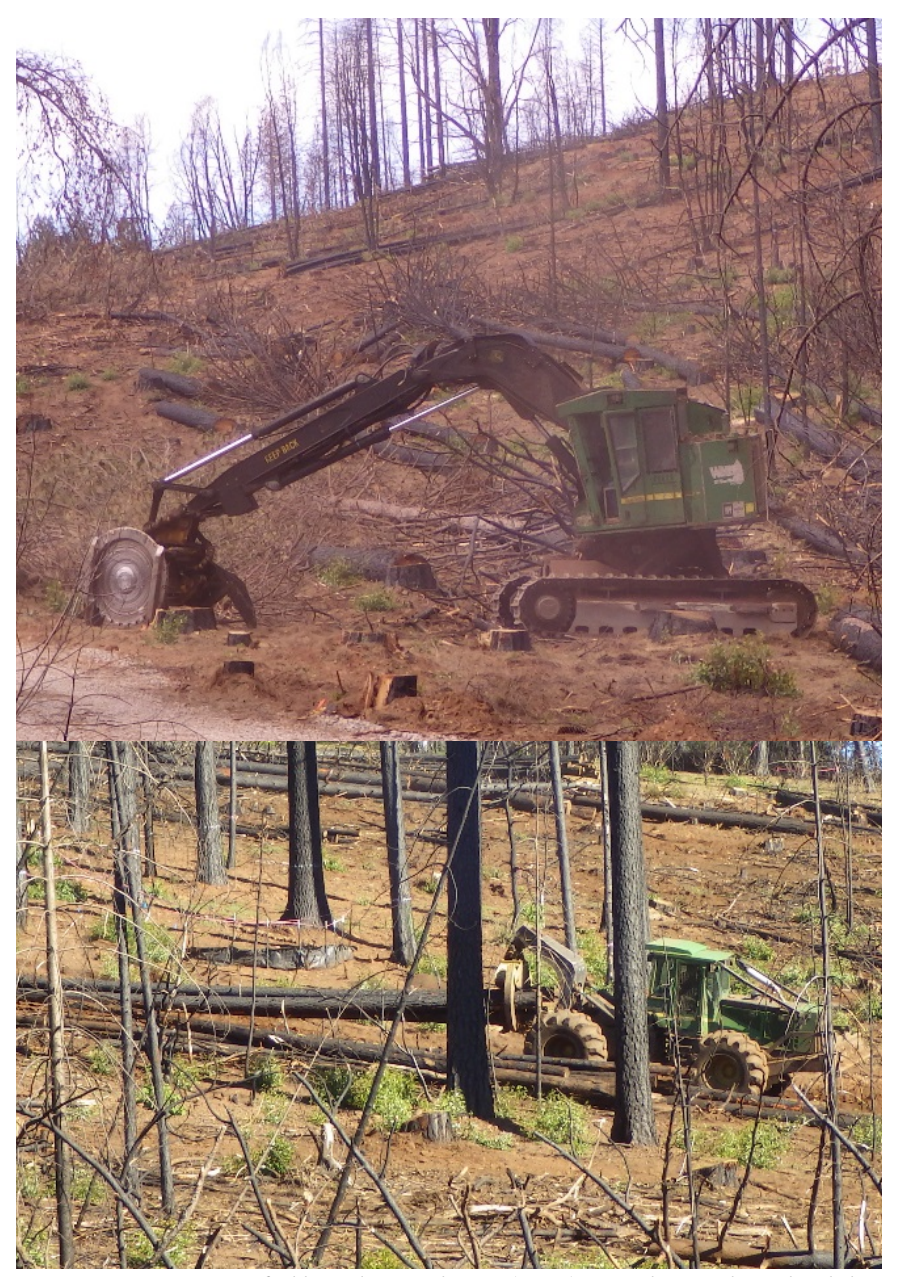

Figure 3.1: A feller buncher (top) and a wheeled log skidder retrieving a bundle of trees (Bottom). 


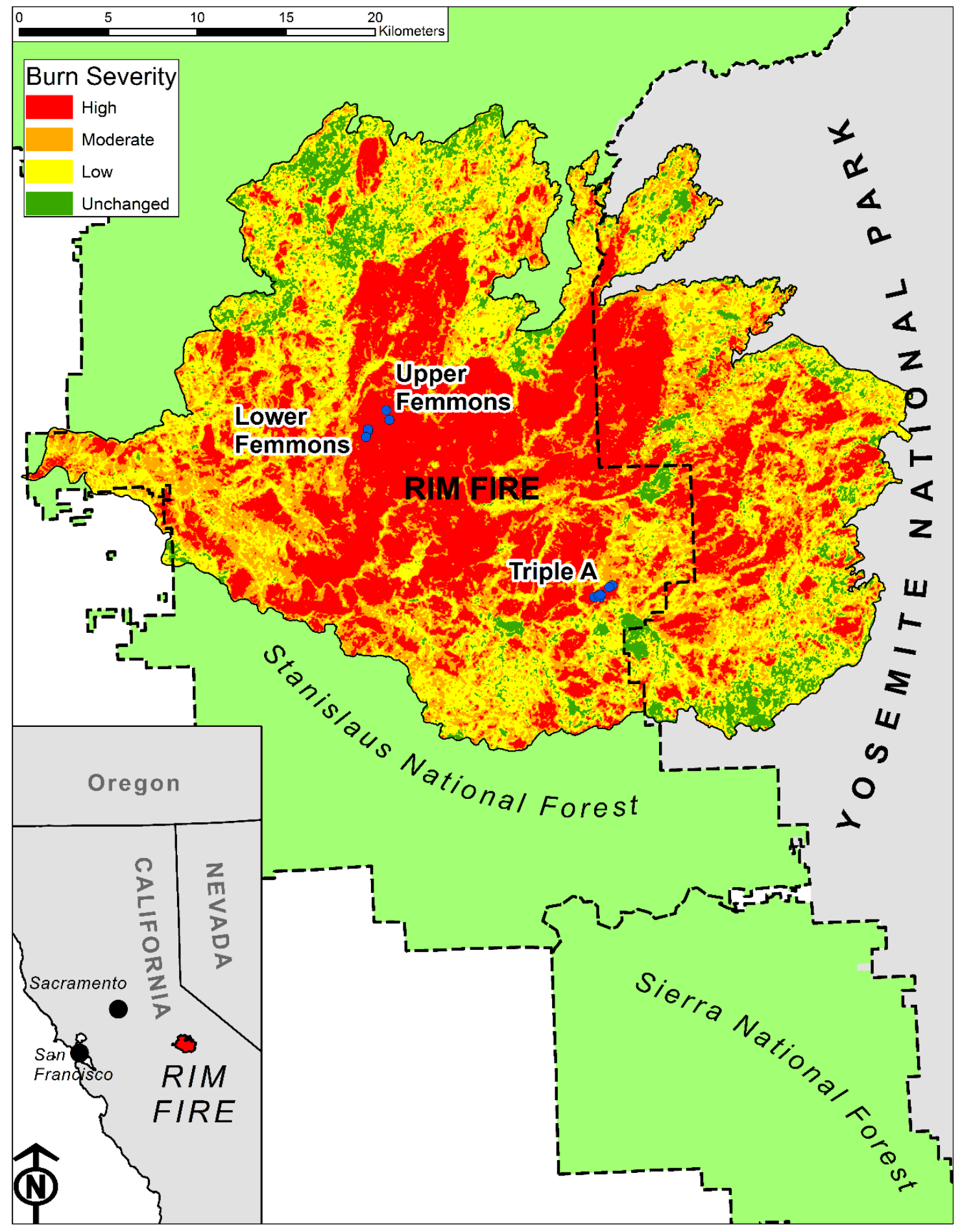

Figure 3.2: 2013 Rim Fire burned area, with study unit locations. Swale locations are indicated by blue dots. Burn severity data are from the USDA Forest Service burned area reflectance classification data (USDA, 2016). 


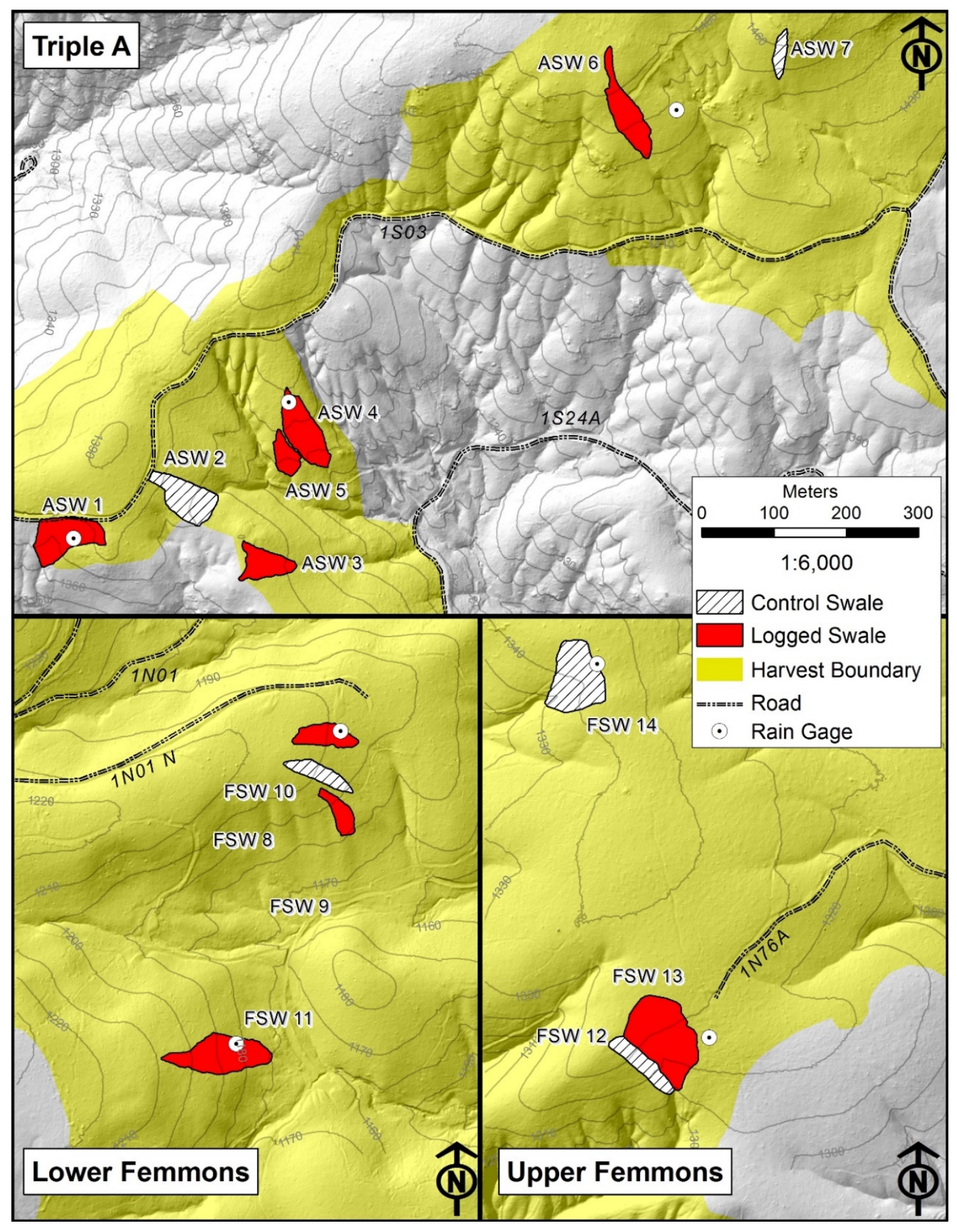

Figure 3.3: Units, swales and rain gage locations within the Rim Fire burned area. Swales treatments and timber harvest boundaries are shown by shading and hatching. LiDAR DEM from Stavros et al. (2013) and NASA JPL. 


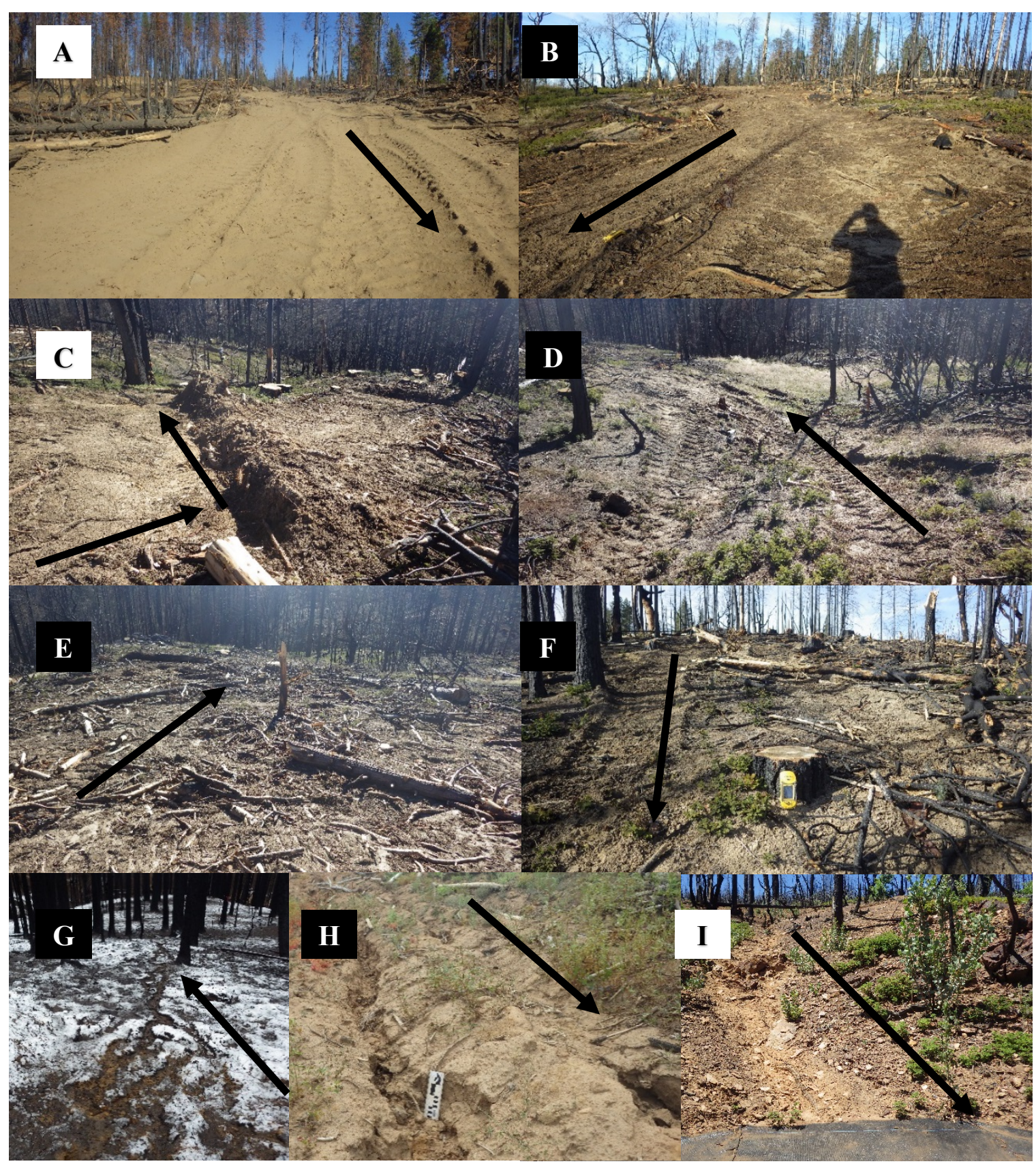

Figure 3.4: Photos of soil disturbance categories, rills, and channel: high traffic skid trails $(A, B)$, waterbar $(C)$, low traffic skid trail $(D)$, mixed traffic $(E)$, feller buncher tracks $(F)$; rills $(G, H)$, and ephemeral channel $(I)$. Black arrows indicate downslope direction. 


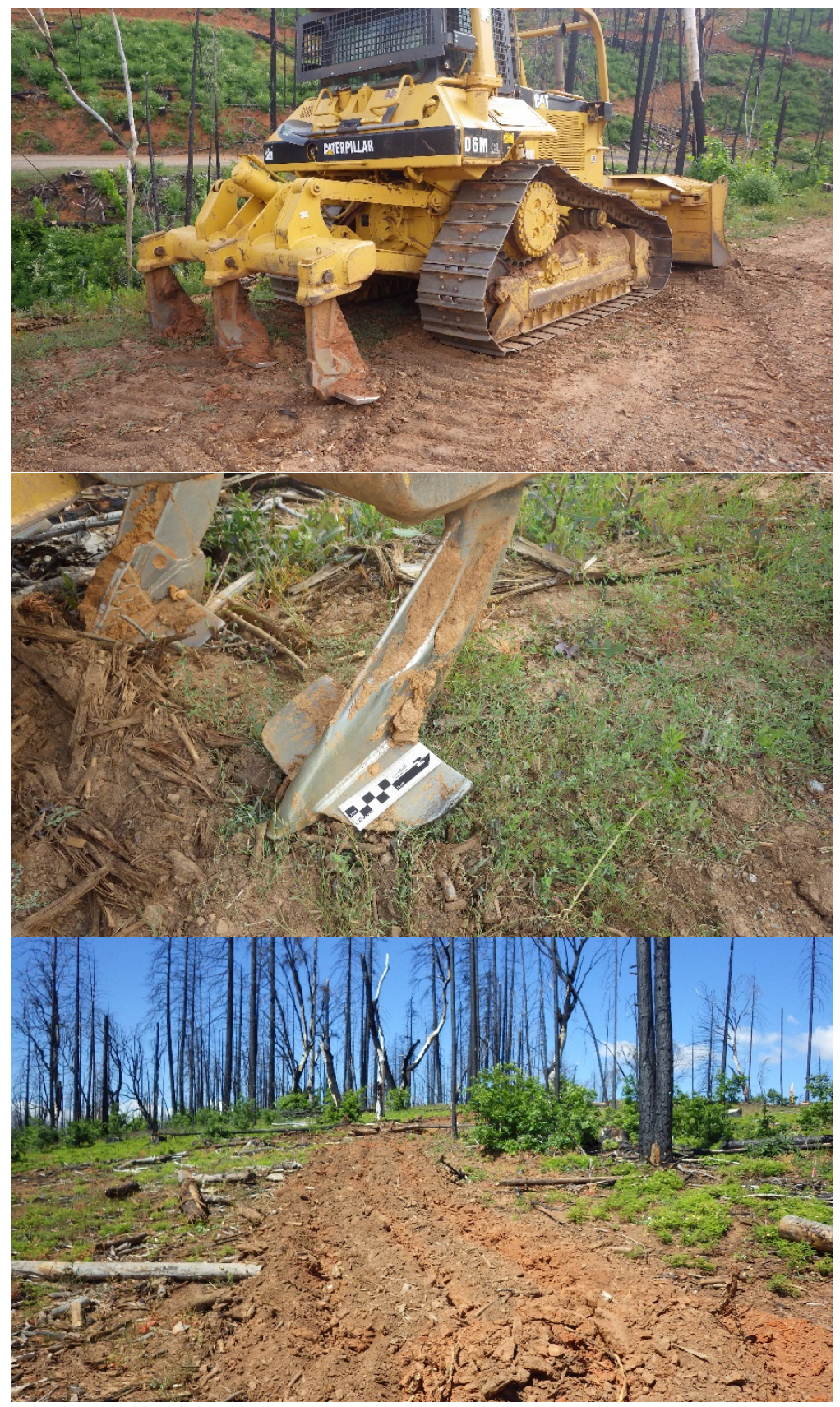

Figure 3.5: Bulldozer equipped with shanks for subsoiling (Top), close up of "winged" shanks from the opposite perspective (Middle), and subsoiled skid trail (Bottom). 


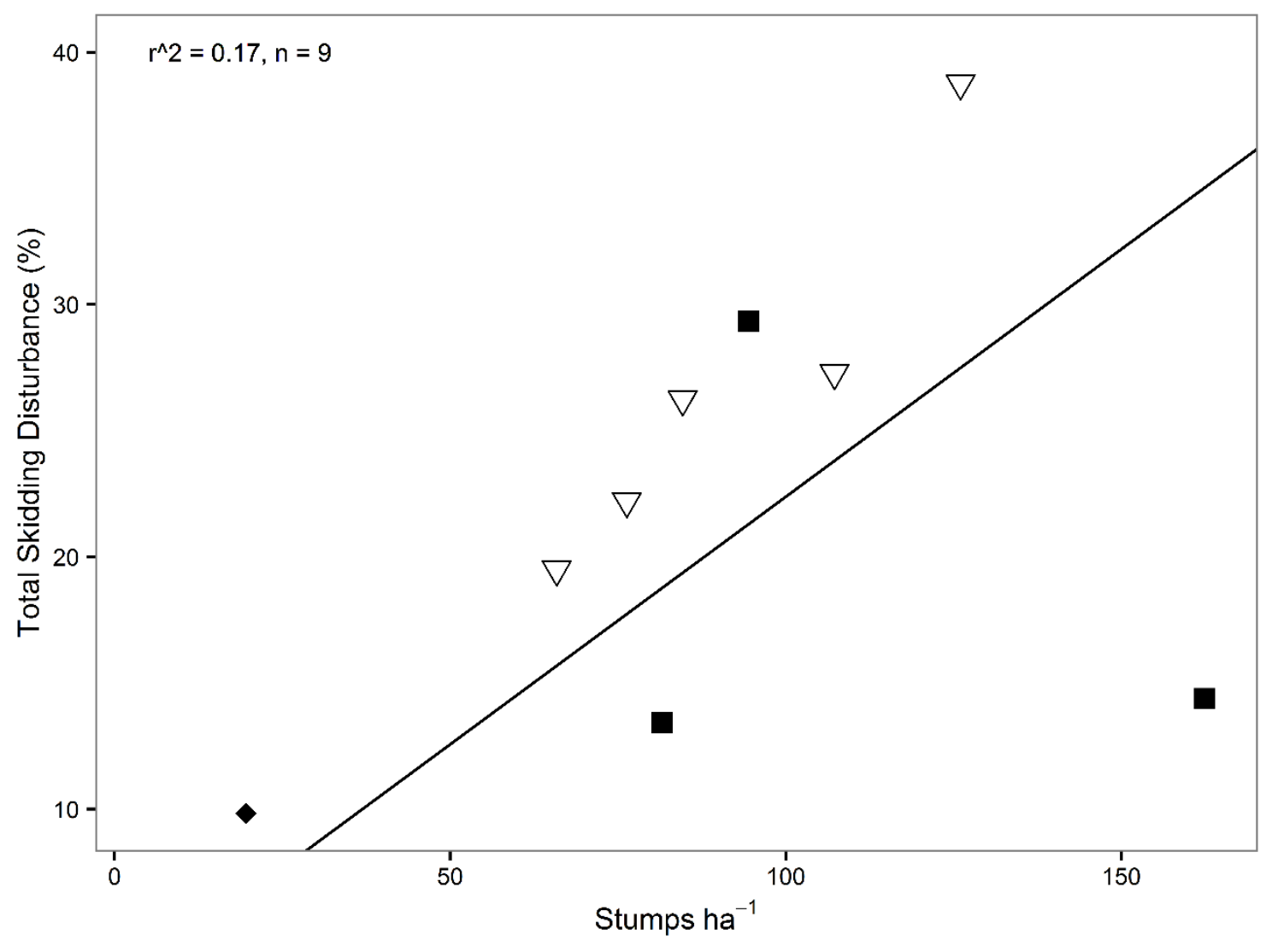

- Lower Femmons $\nabla$ Triple $A \diamond$ Upper Femmons

Figure 3.6: Total skidding disturbance and stumps $h a^{-1}$ within logged swales. 


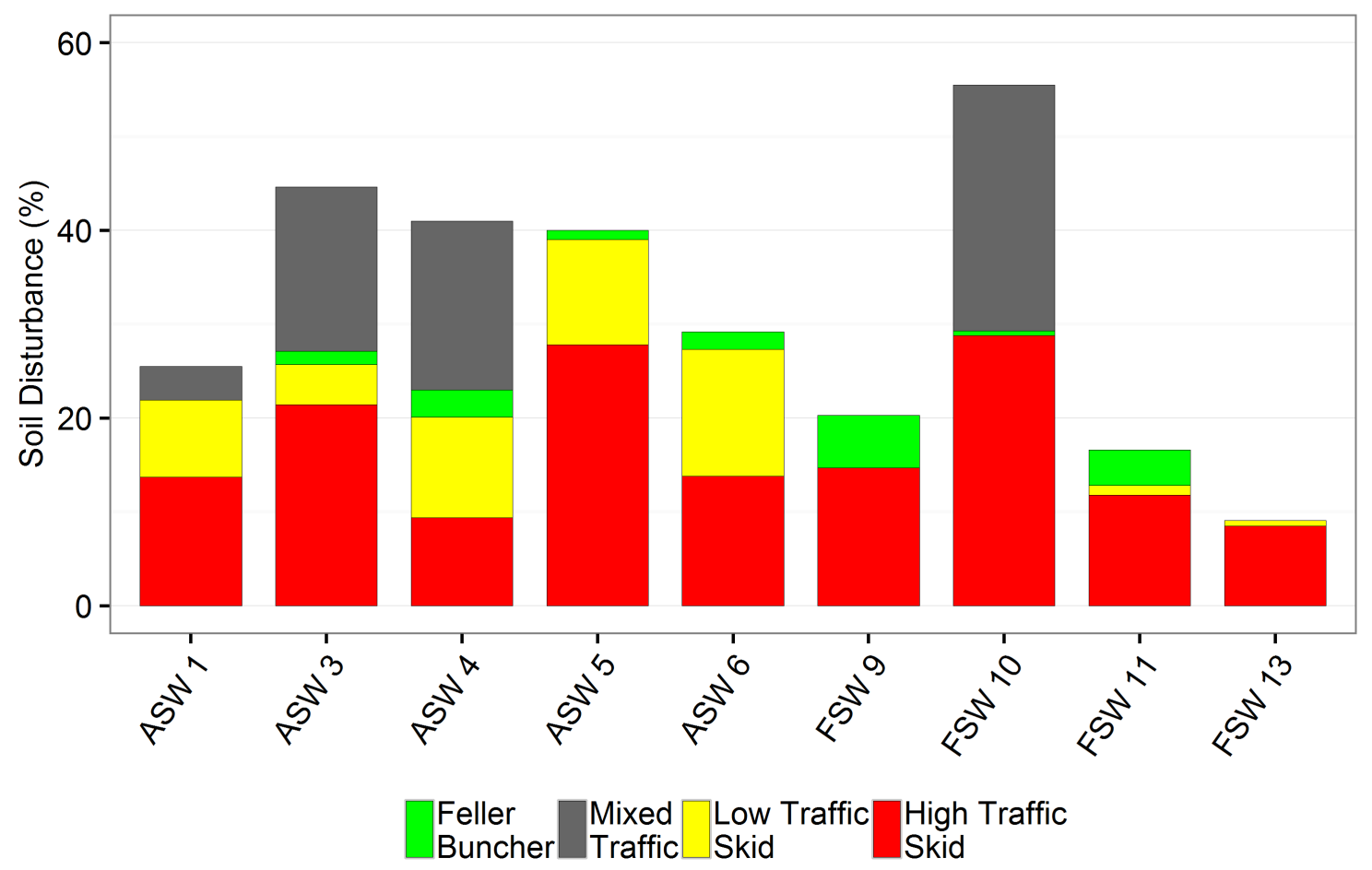

Figure 3.7: Soil disturbance from post-fire salvage logging and disturbance type for each swale. Values are percent area of each logged swale. 


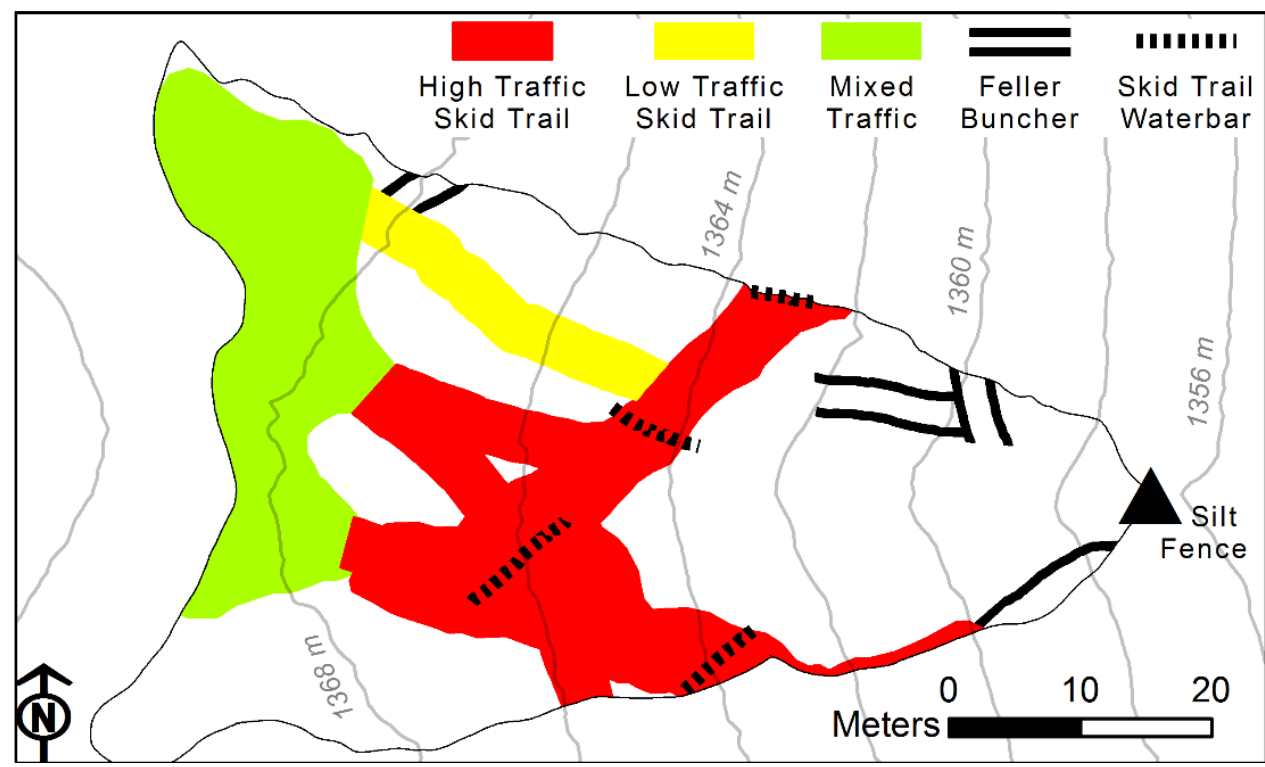

Figure 3.8: Surveyed soil disturbance following logging in November 2014 - January 2015 in swale ASW 3. Disturbances and waterbars sometimes extend beyond swale boundaries. 


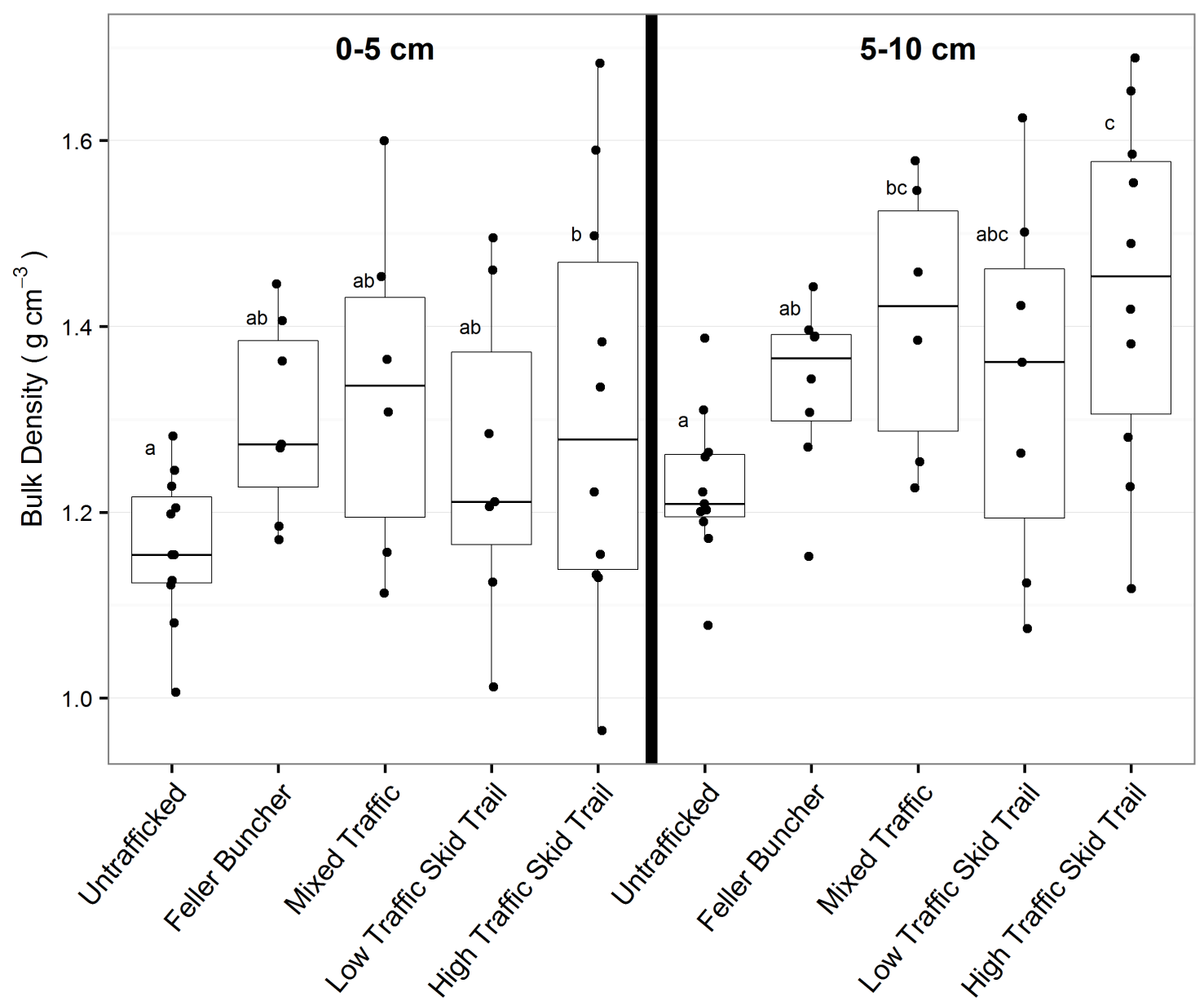

Figure 3.9: Soil bulk density for each disturbance class by depth. Different superscripts indicate significant differences $(\alpha=0.05)$ within each depth. Box plots represent median (horizontal black bar), $25^{\text {th }}$ and $75^{\text {th }}$ quantiles (box bounds), and 1.5 times the interquartile range (whiskers). Dots are individual values. 


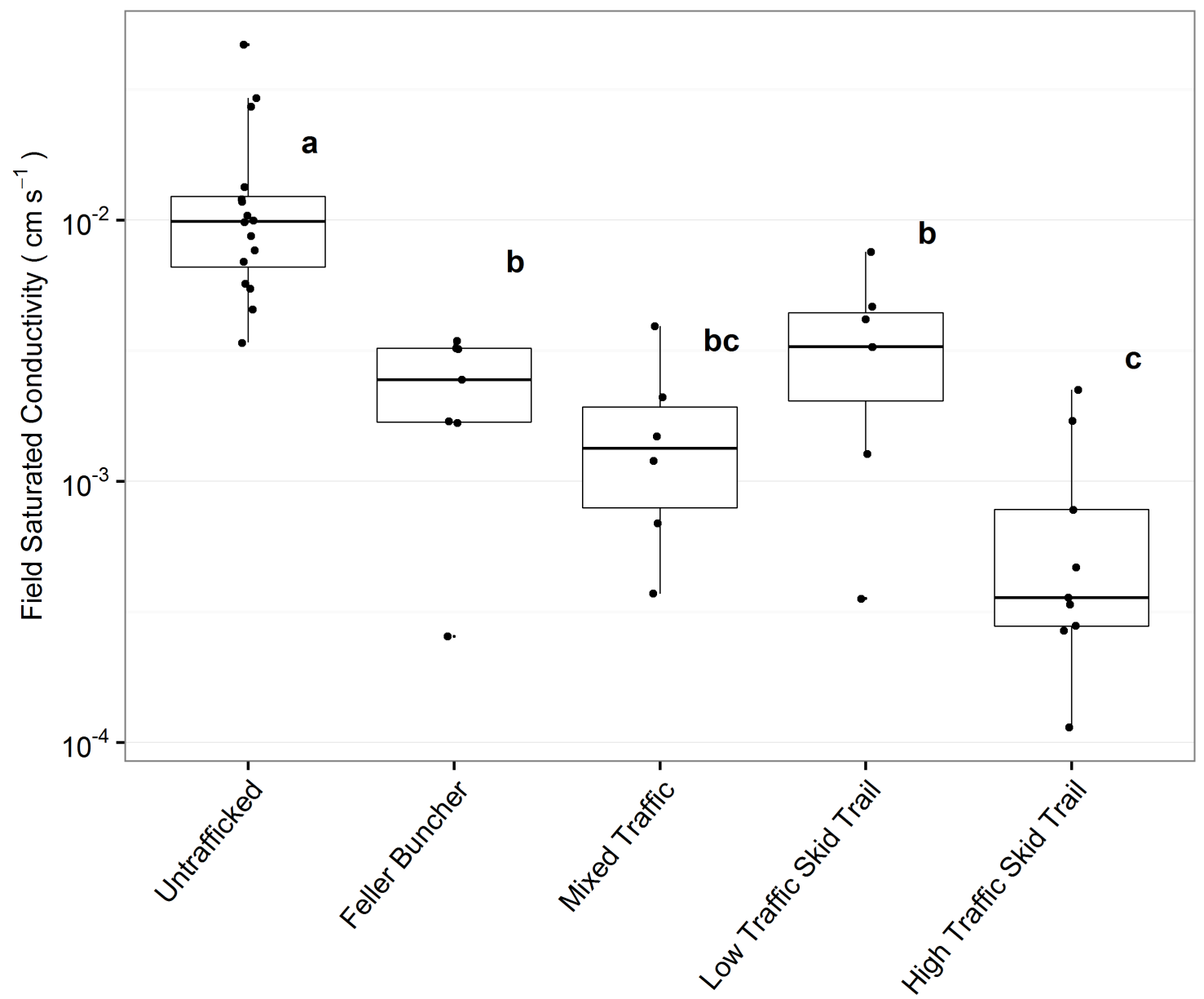

Figure 3.10: Field saturated hydraulic conductivity by disturbance type. Different superscript letters indicate significant differences between the means of disturbance types $(\alpha=0.05)$. Boxplot characteristics are the same as figure 3.9. 
A

Triple A

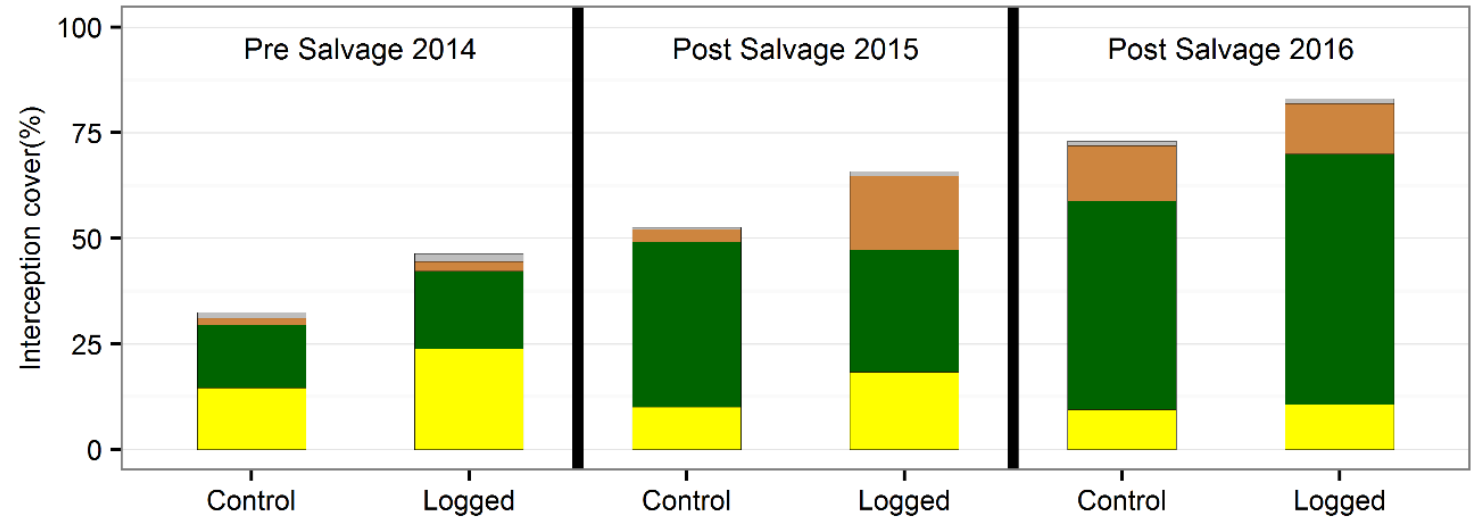

B

Lower Femmons
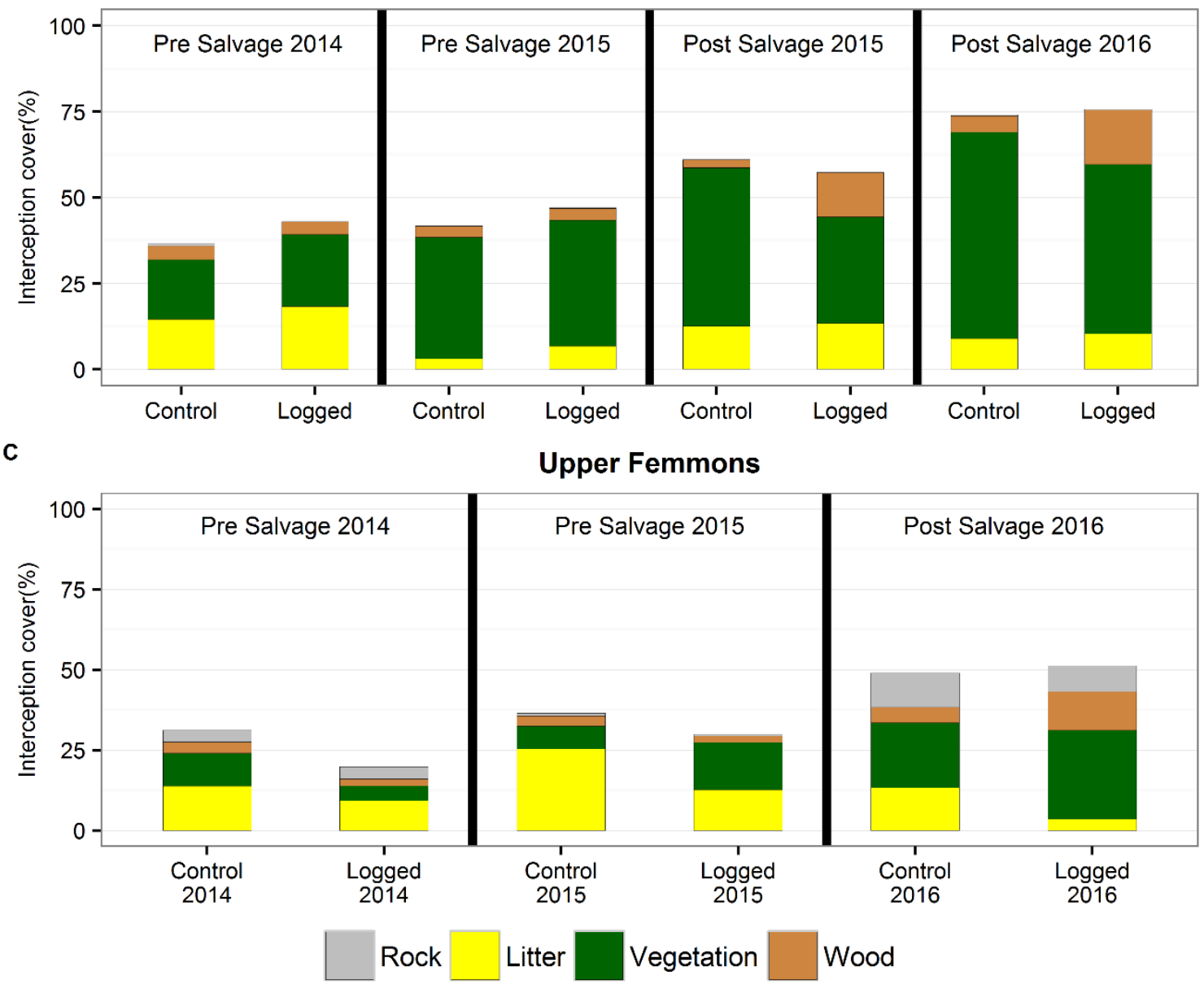

Figure 3.11: Mean interception ground cover by cover class and treatment for each unit. 100 minus the total ground cover is the percent exposed bare soil. 
A

Triple A

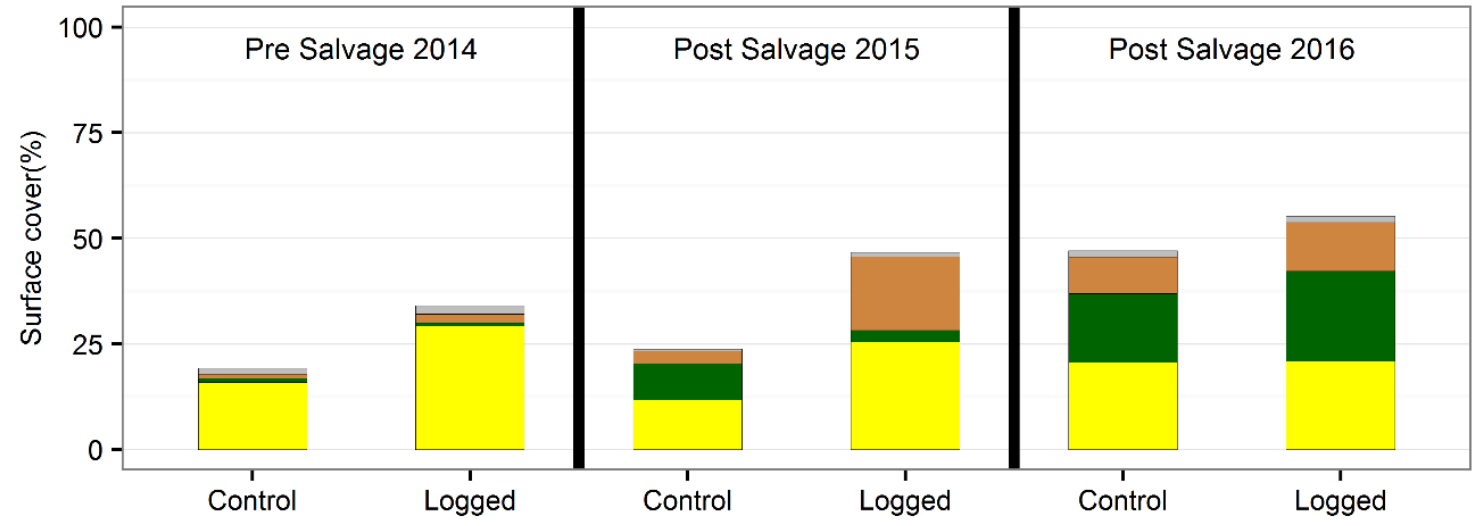

B

Lower Femmons
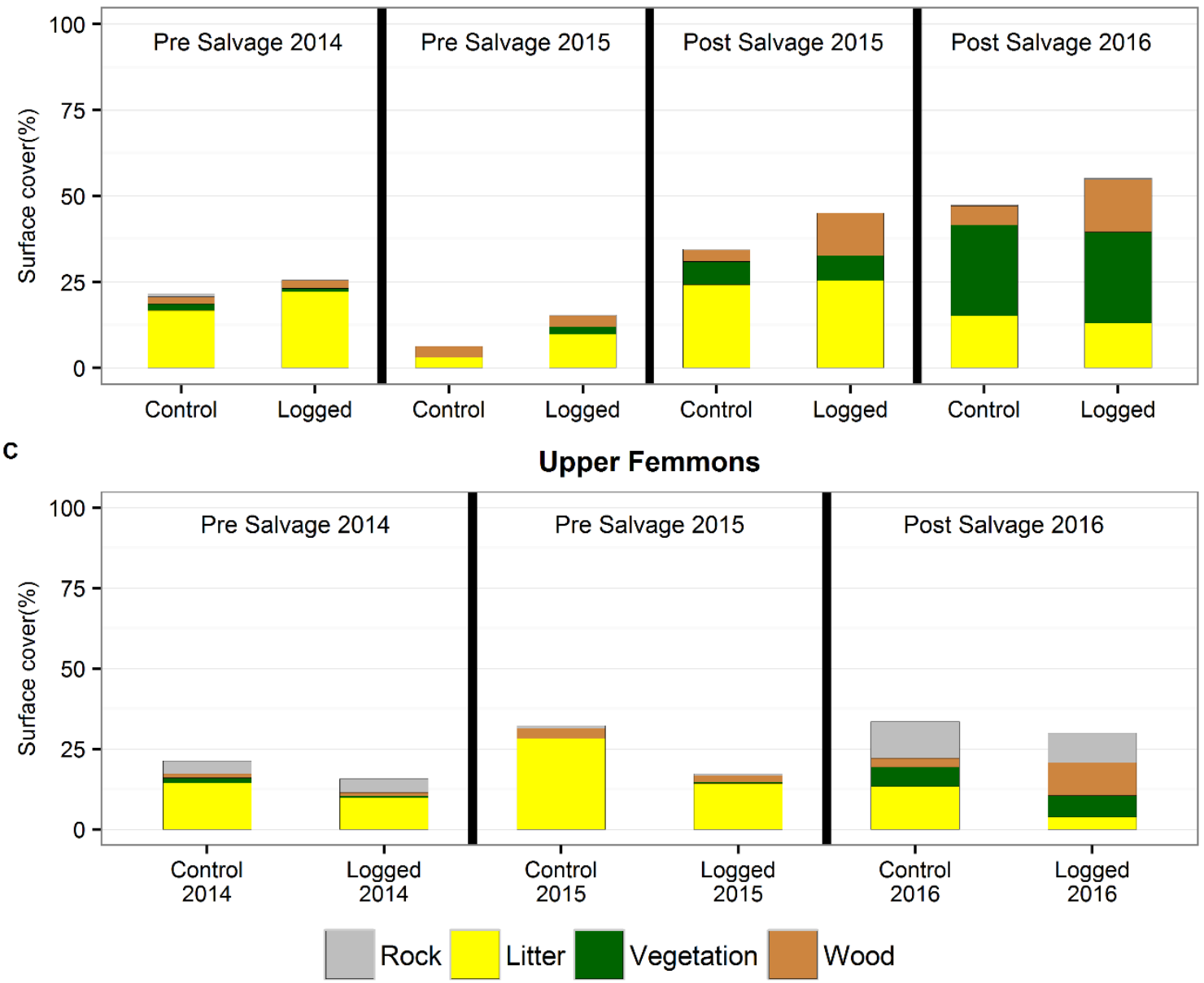

Figure 3.12: Mean surface ground cover by cover class and treatment for each unit. 100 minus the total ground cover is the percent total bare soil. 

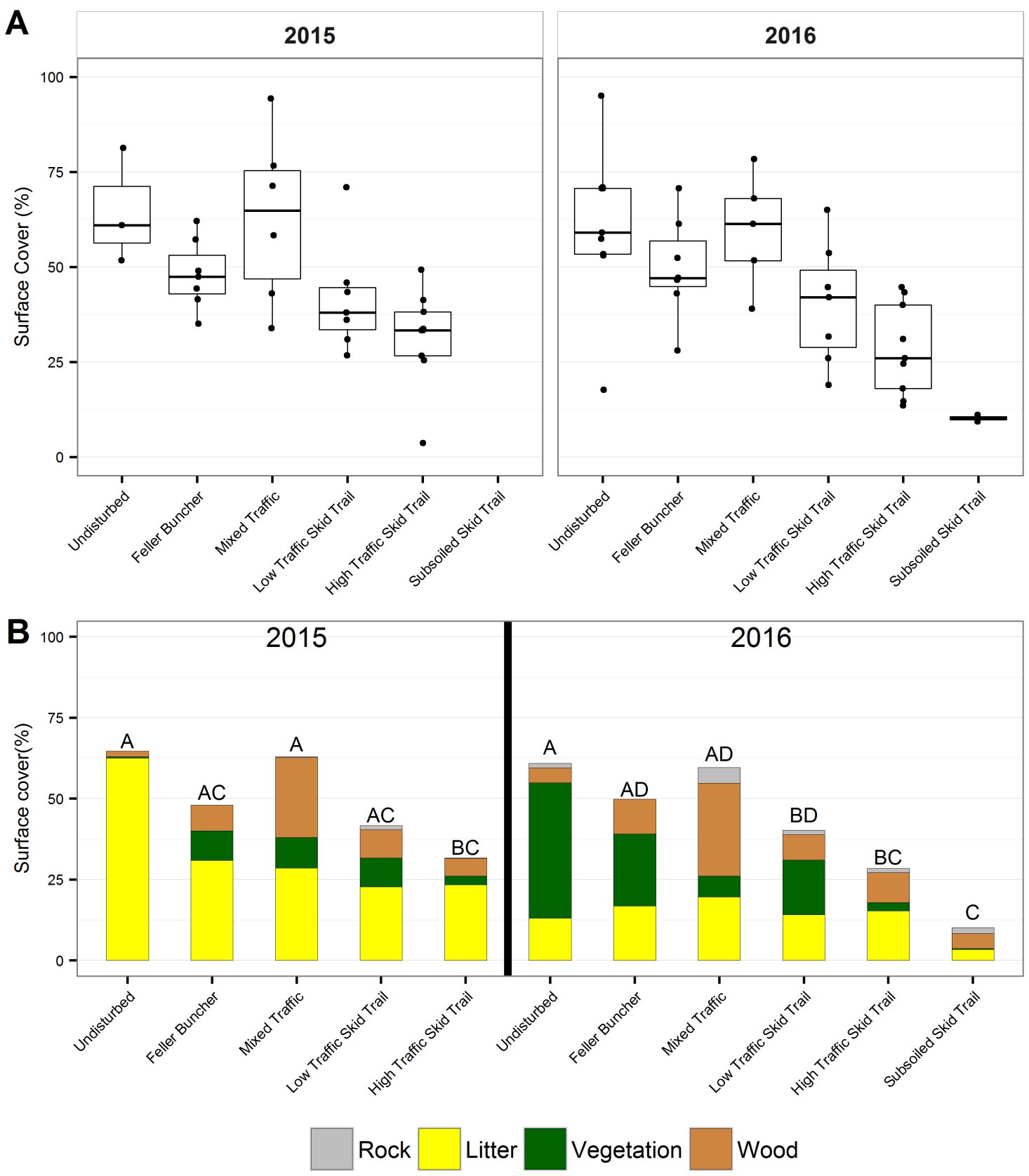

Figure 3.13: Surface cover in disturbed areas across Rim Fire swales. Panel A illustrates total surface cover within and across disturbance classes. Boxplot features are the same as figure 3.9. Panel B is mean cover type for each disturbance class. 100 minus the total surface cover is the percent bare soil. 

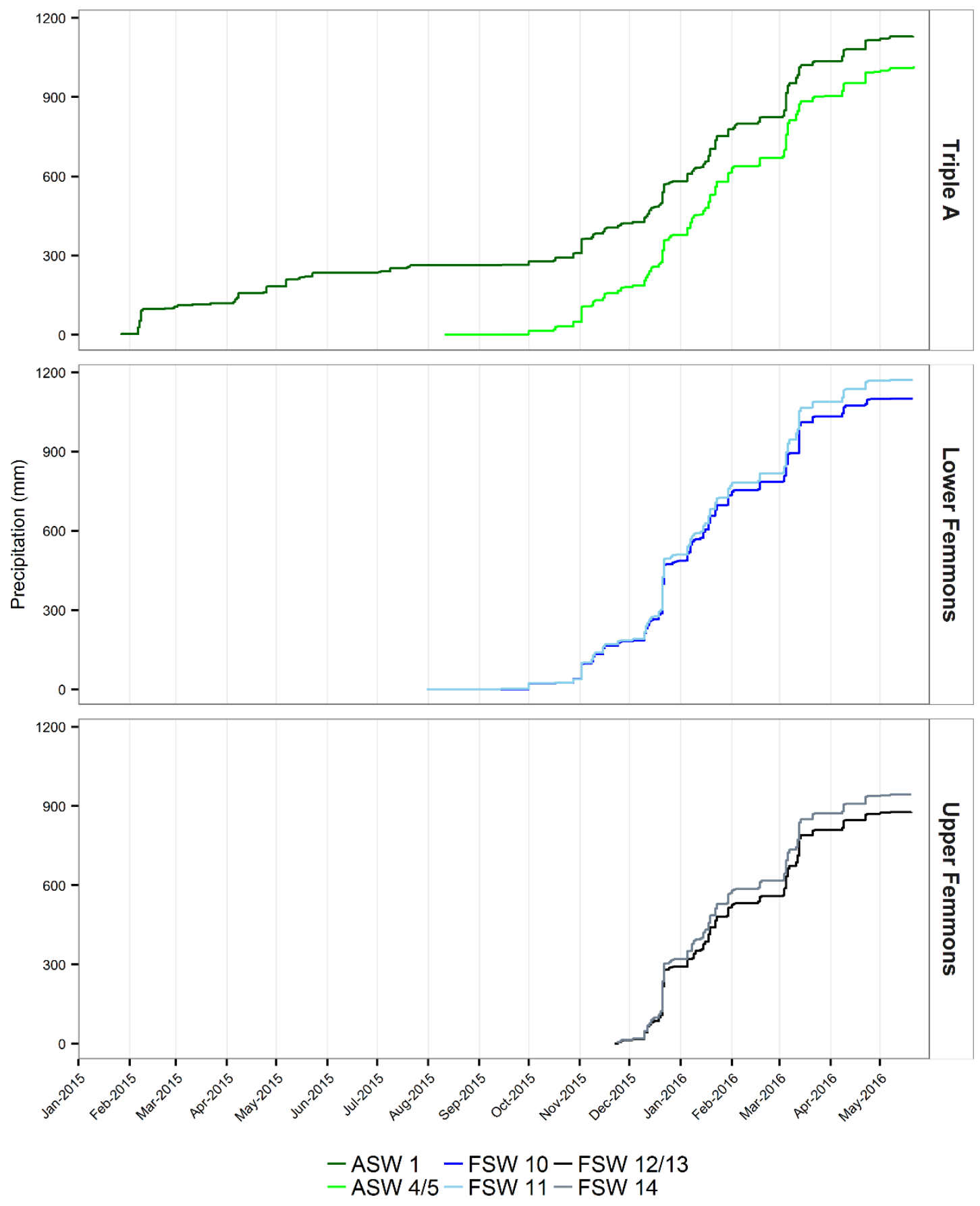

Figure 3.14: Daily cumulative rainfall in the Rim Fire swales. Large storm events are visible in Triple A in February, May, and June 2015, while several storm events are visible across all three units during the 2015-2016 winter season. 

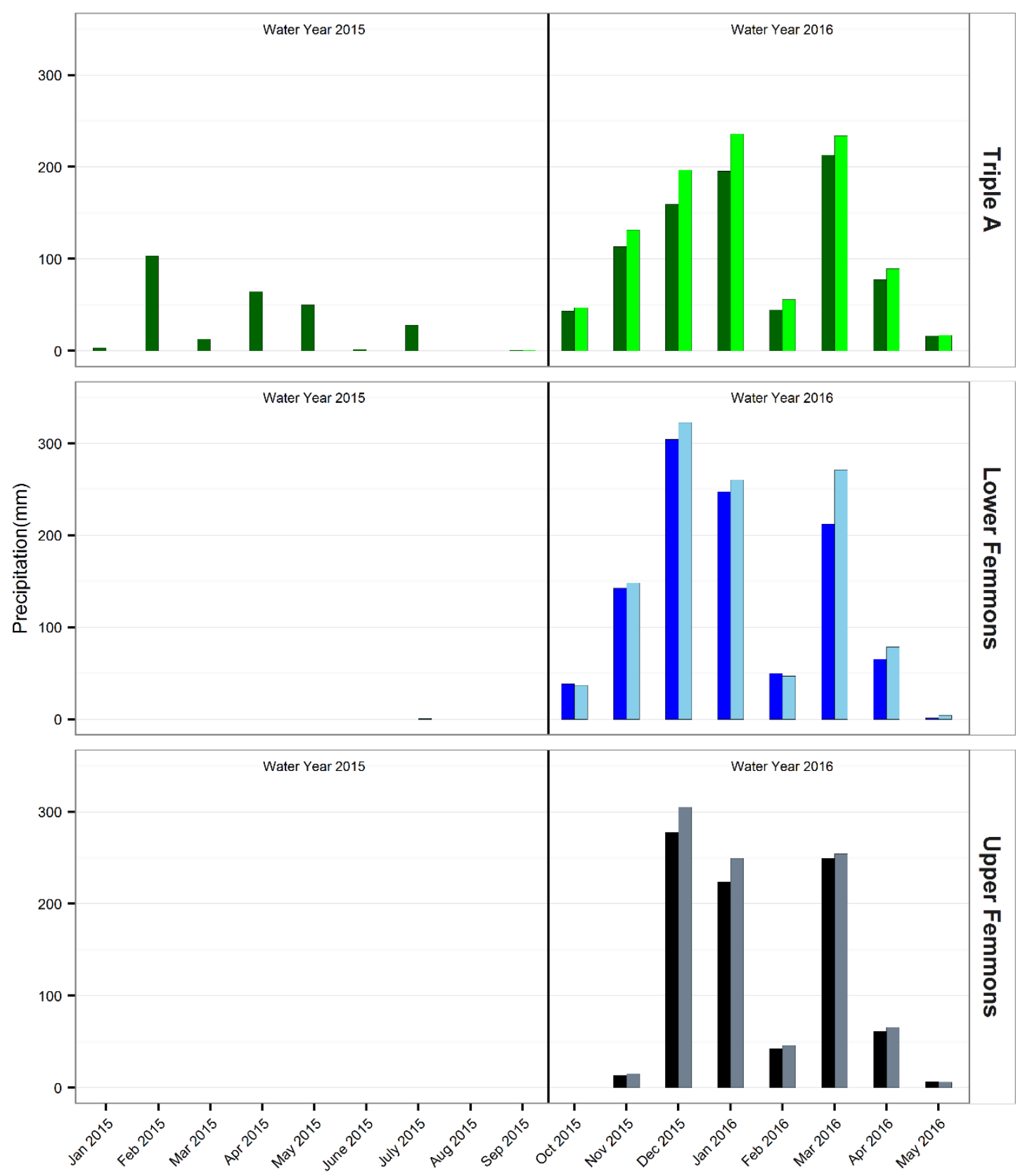

ASW 1 FSW 10 FSW 12-13

ASW 4-5 FSW 11 FSW 14

Figure 3.15: Monthly rainfall totals for each rain gage. Note that water year 2016 was an El Nino year, explaining elevated rainfall. Additionally, no rain gages were installed before July 2015 in Lower Femmons, and none before November 2015 in Upper

Femmons. 

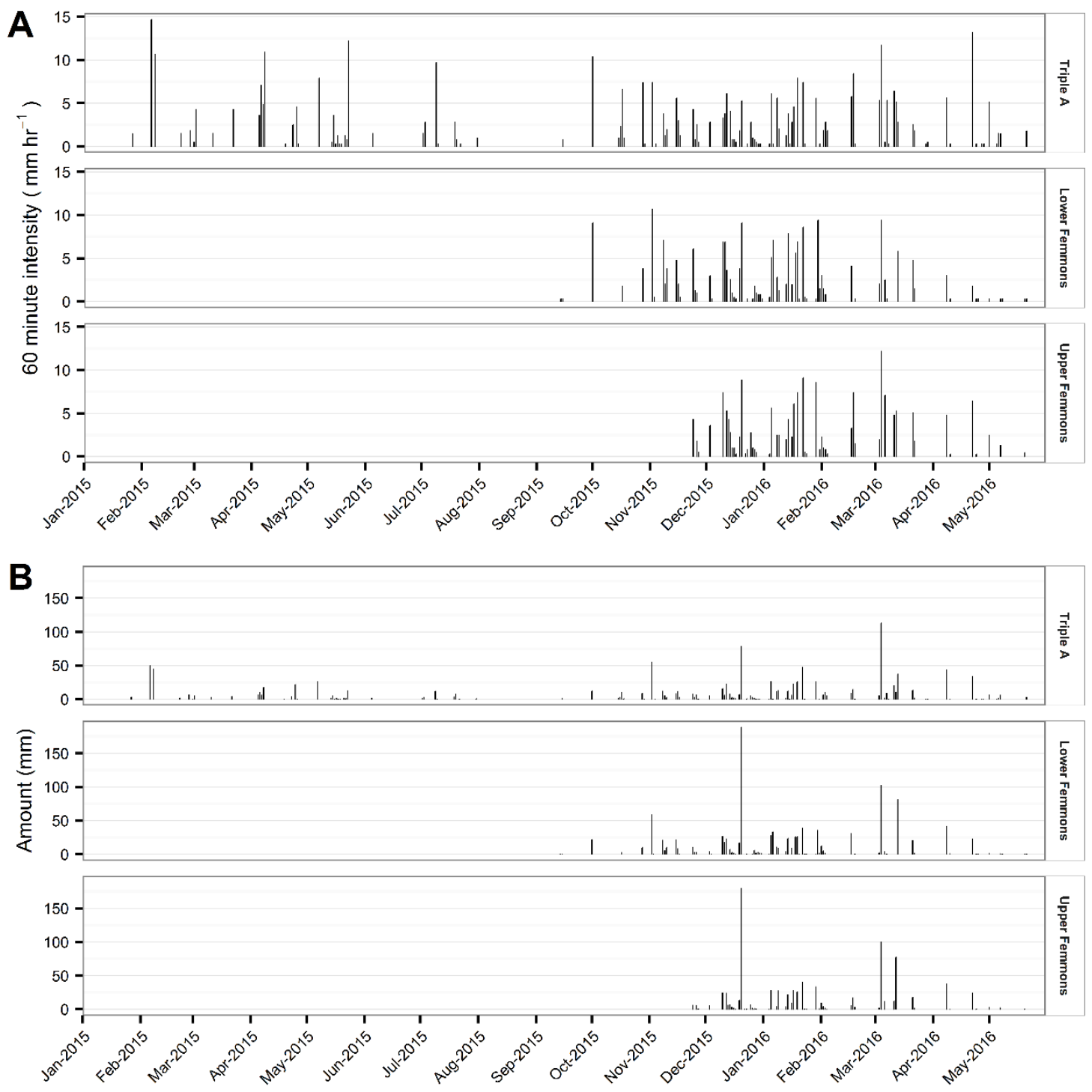

Figure 3.16: 60-minute maximum rainfall intensity $\left(I_{60}\right)$ by rainfall event $(A)$ and cumulative total by rainfall event $(B)$ within each unit. The gage in $A S W 1$ represents Triple A and was installed January 2015, FSW 10 represents Lower Femmons and was installed July 2015, and FSW 12/13 represents Upper Femmons and was installed in November 2015. 


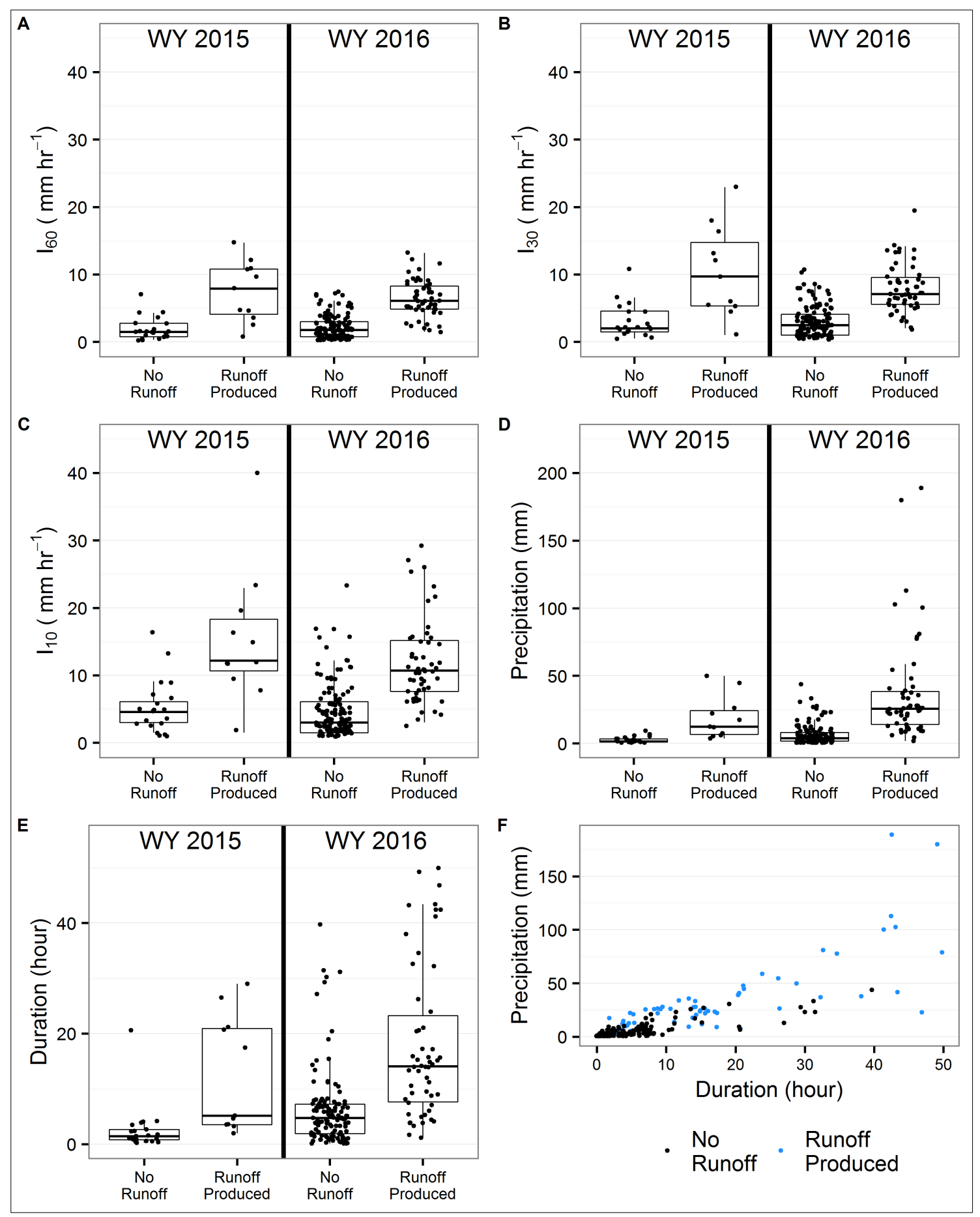

Figure 3.17: Rainfall characteristics of runoff producing storms by water year. (A) $I_{60}$, (B) $I_{30},(C) I_{10},(D)$ total precipitation, $(E)$ storm duration, and $(F)$ precipitation versus duration. Boxplot characteristics are the same as Figure 3.9. 


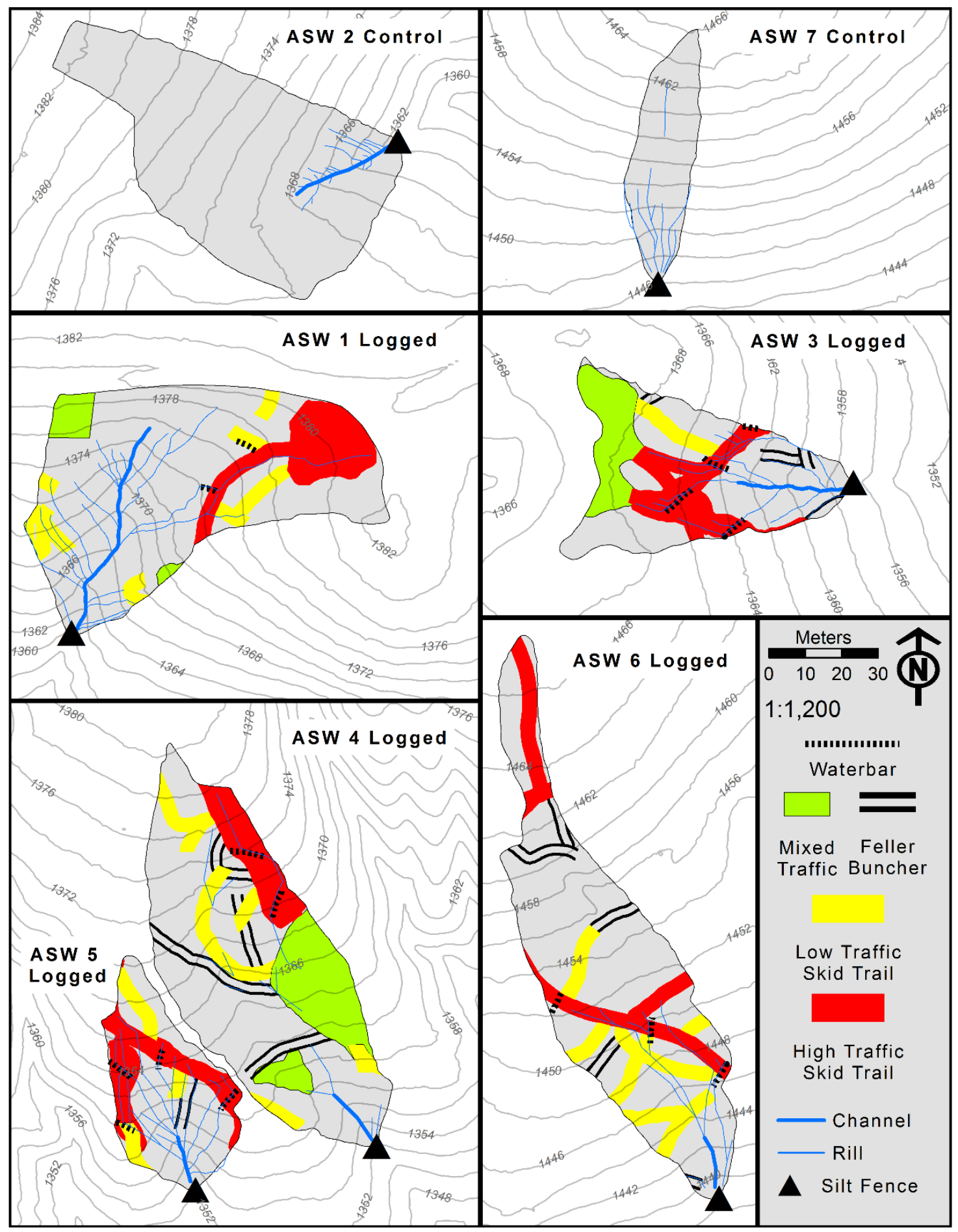

Figure 3.18: Triple A post-salvage rill networks. 


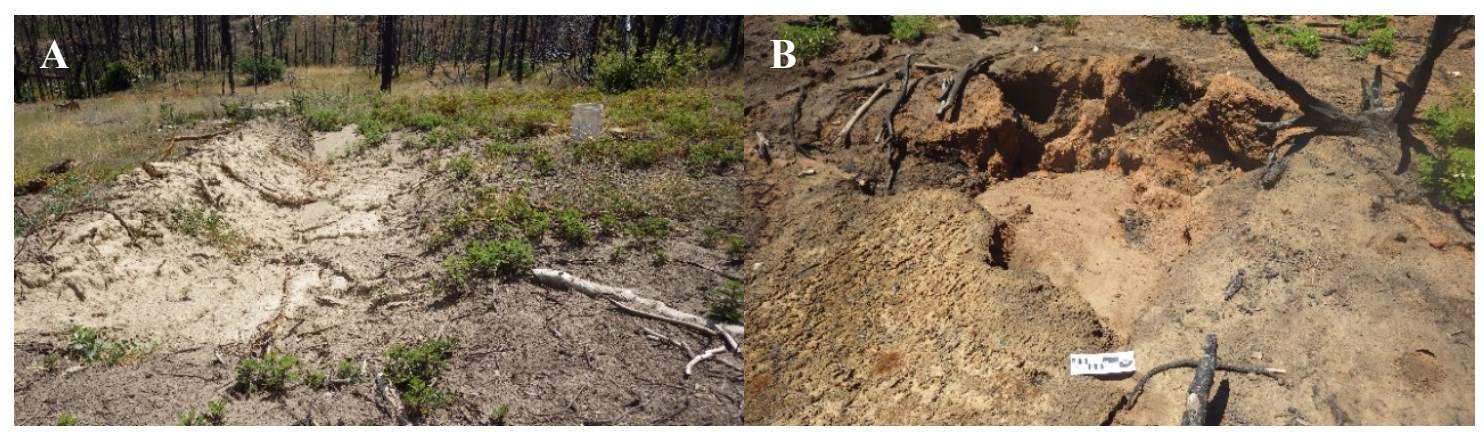

Figure 3.19: Examples of features that disconnected rills. Dense vegetation below a skid trail in $A S W 4(A)$, and a stump hole in FSW 8 (B). 


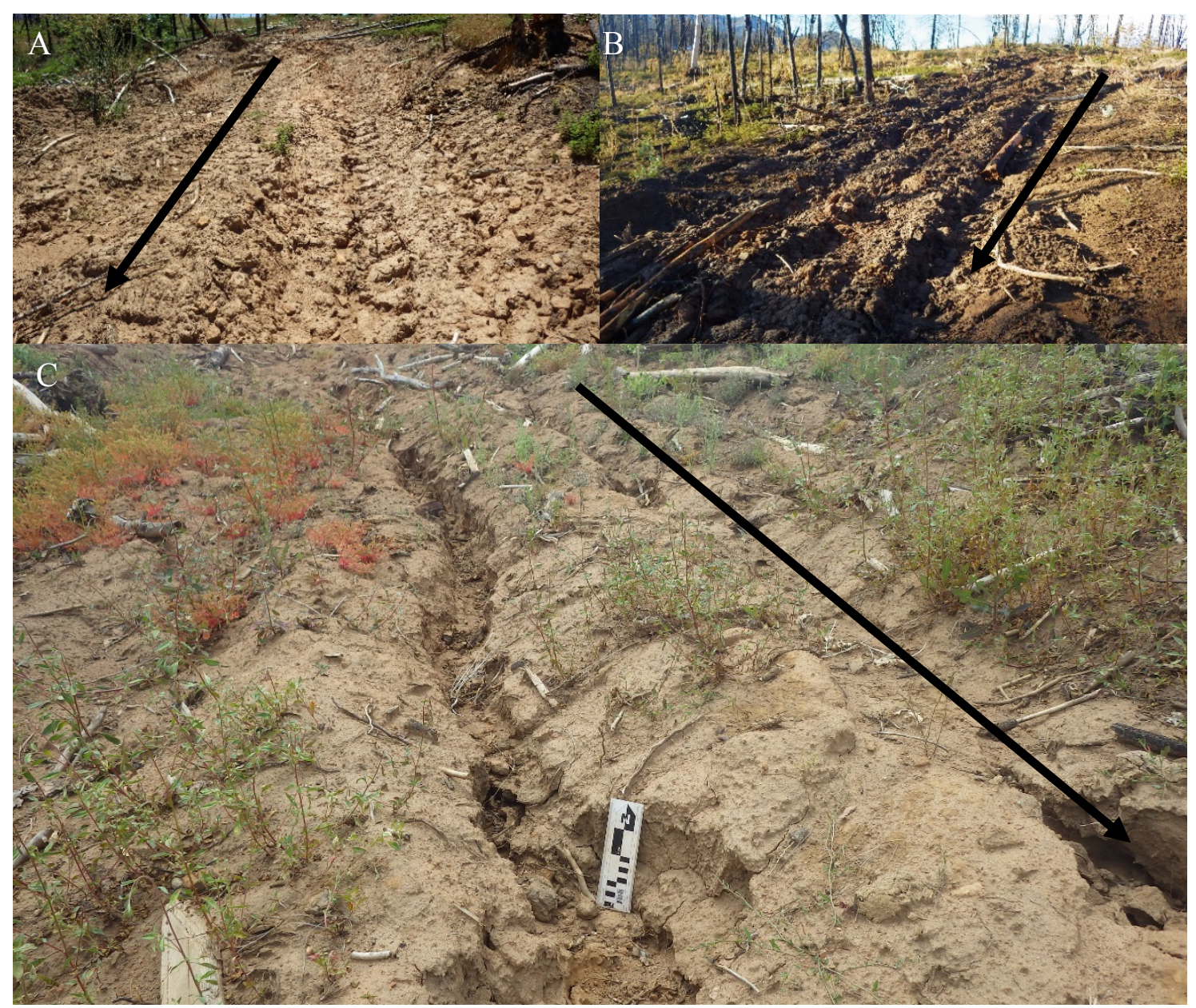

Figure 3.20: High traffic skid trail in ASW 3 before (A) and after (B) subsoiling. Deep rills formed in the subsoiled areas $(C)$. Arrows indicate the down slope direction on the skid trails. 


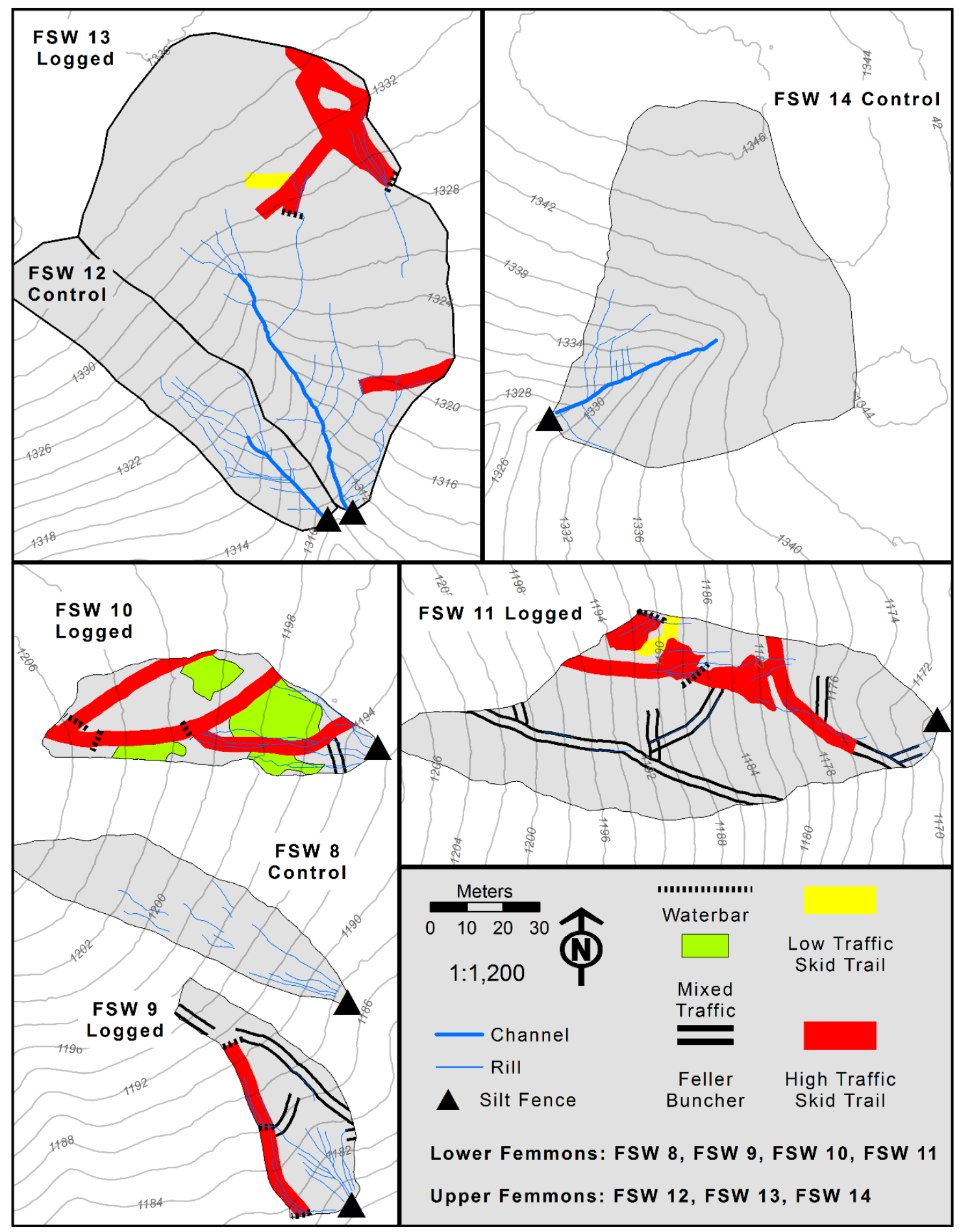

Figure 3.21: Post-salvage rill networks in Lower and Upper Femmons. 


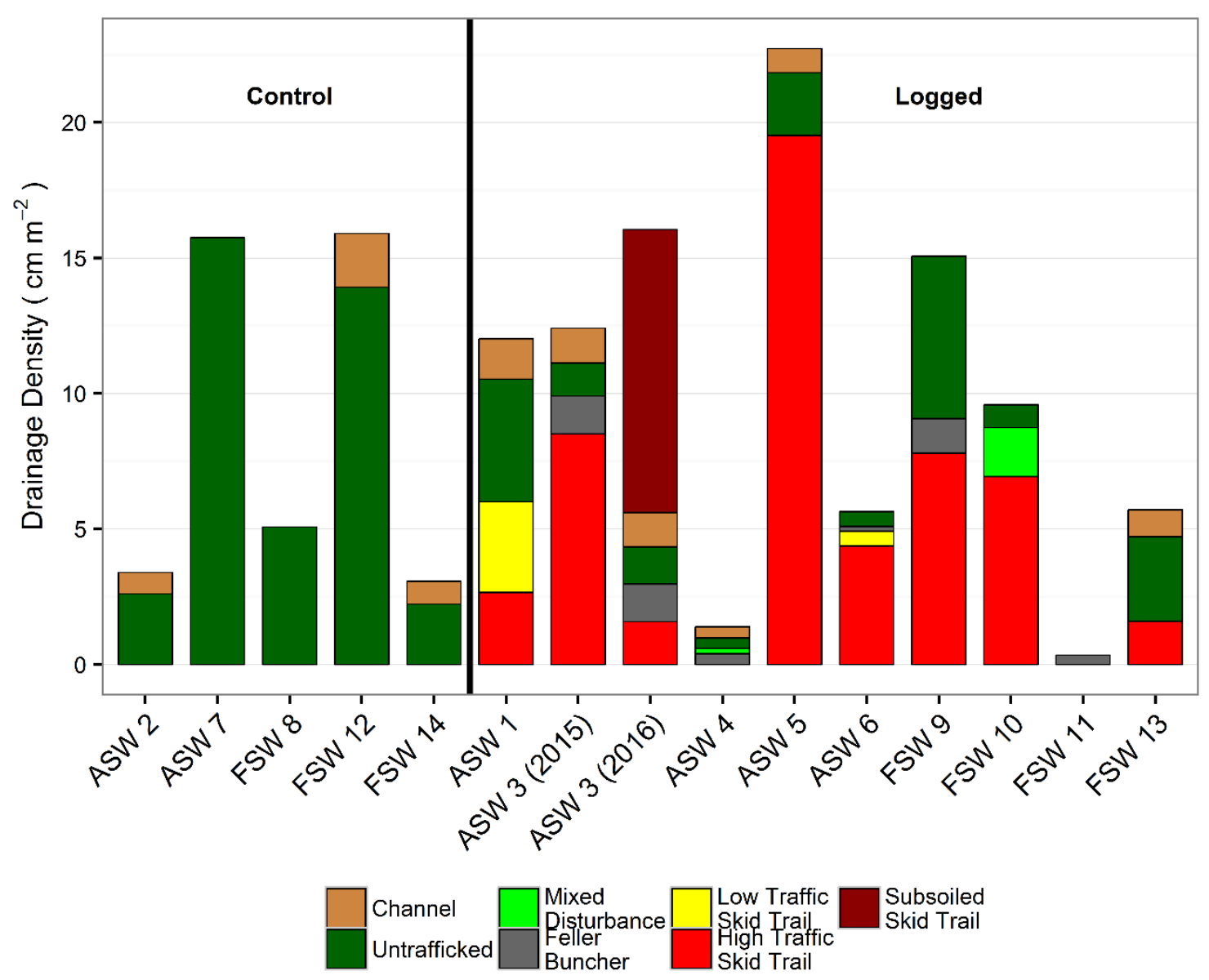

Figure 3.22: Rill densities by disturbance class at initiation point for each swale. ASW 3 is shown before (2015) and after (2016) subsoiling. 


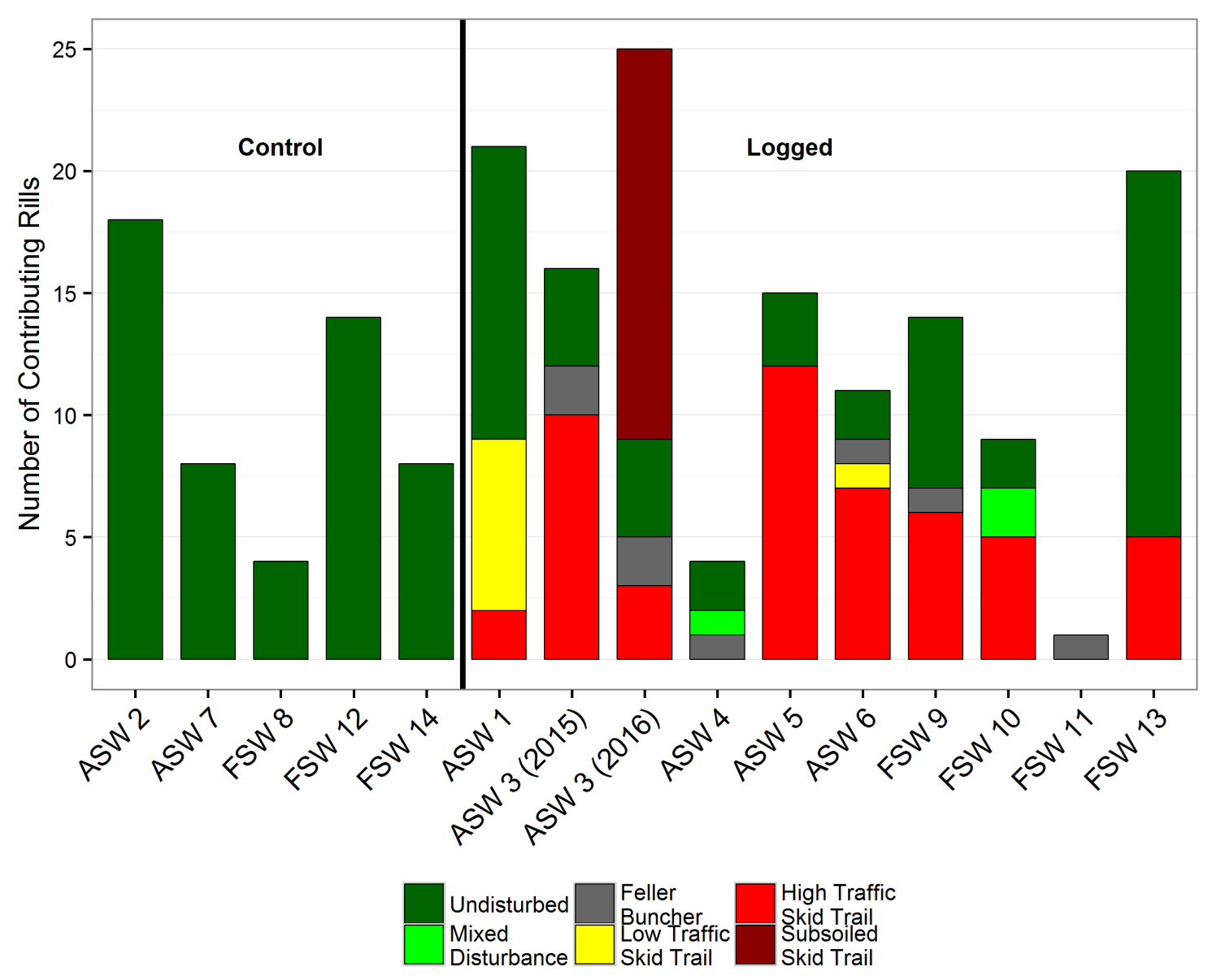

Figure 3.23: Number of contributing rills in each swale by disturbance class at initiation point. ASW 3 is shown before (2015) and after (2016) subsoiling. 


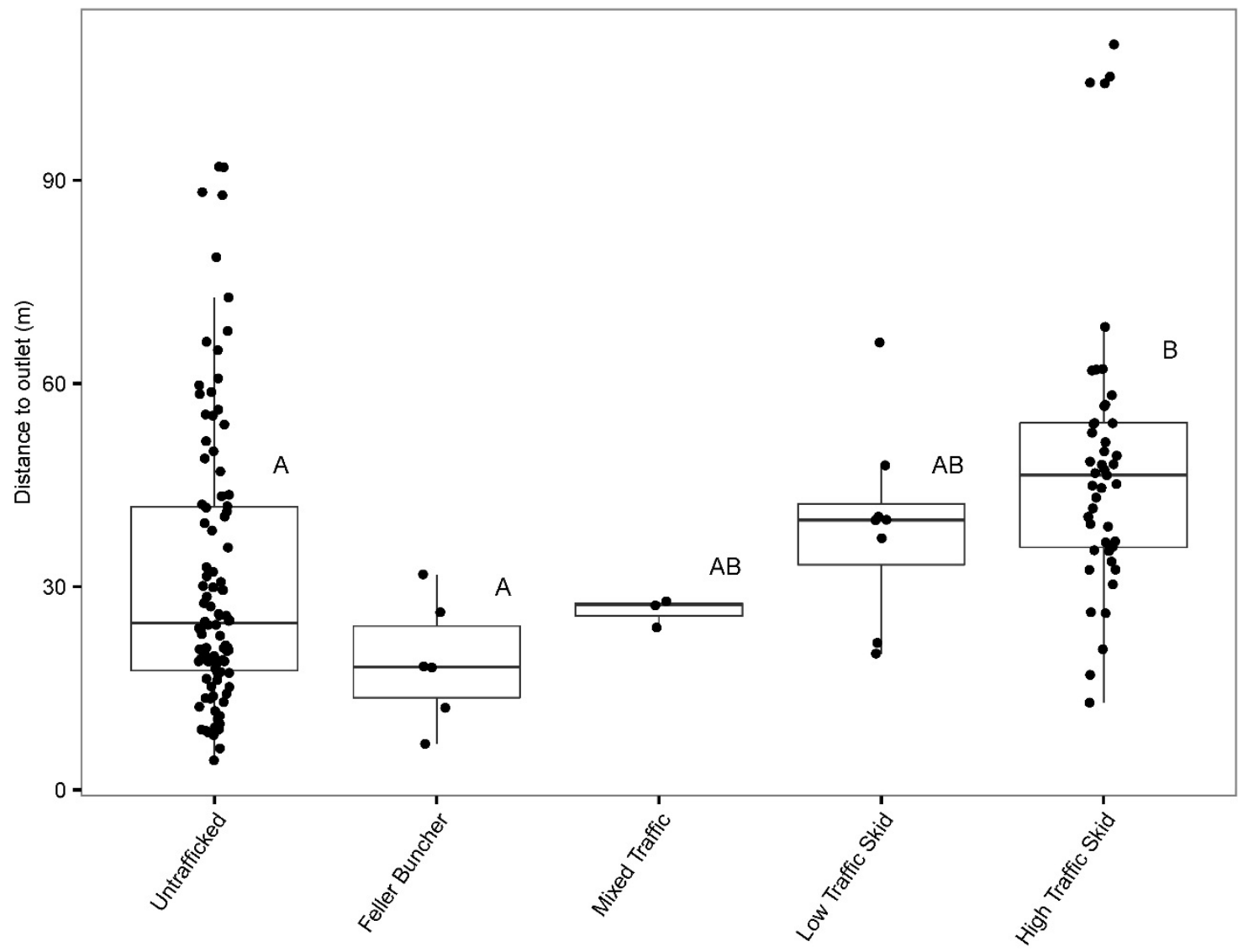

Figure 3.24: Rill length from initiation point to outlet. Different superscripts indicate significant differences $(\alpha=0.05)$. Boxplot characteristics are the same as figure 3.9. 


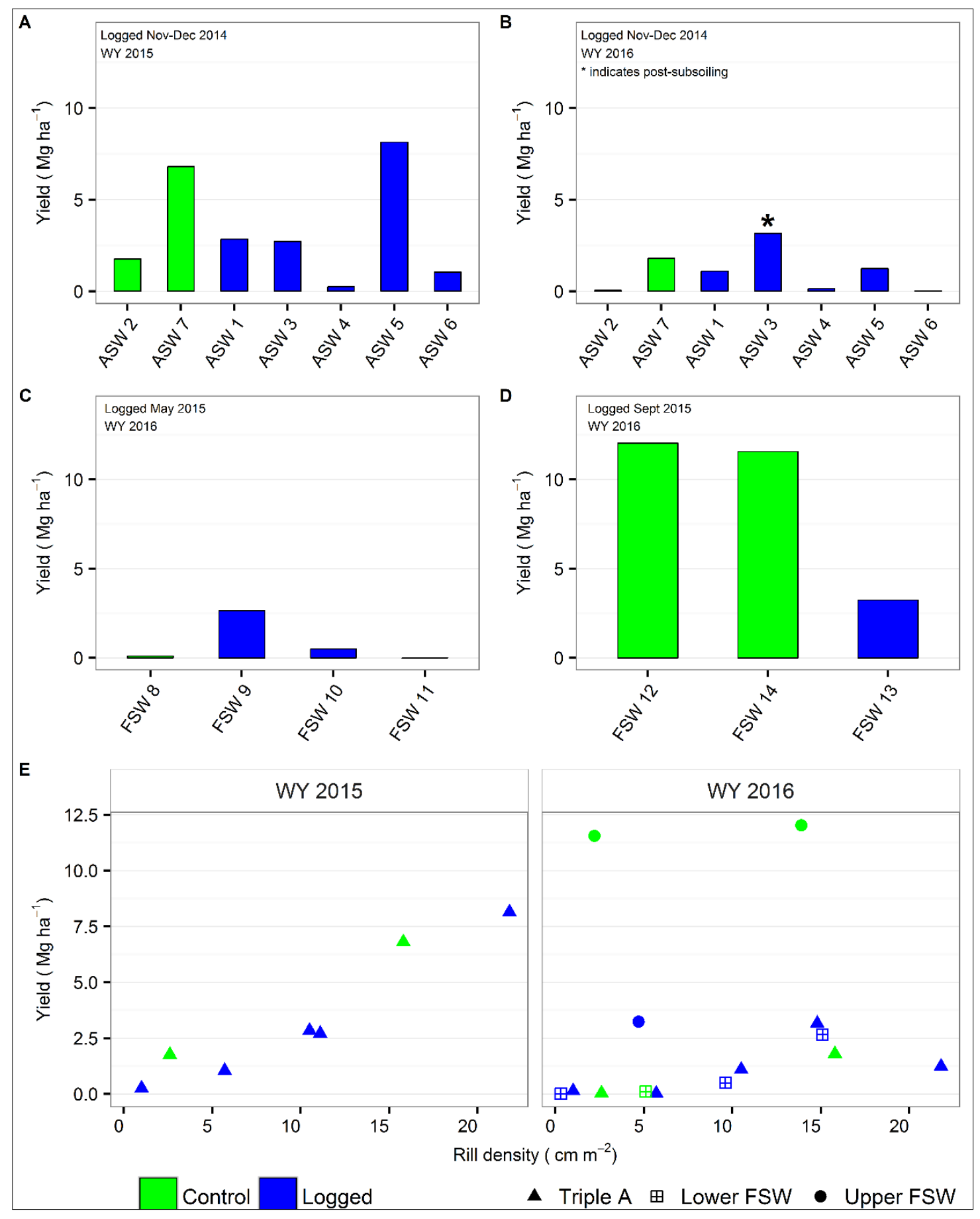

Figure 3.25: Sediment yields in each swale by water year. Triple A water year 2015 (A) and 2016 (B), Lower Femmons water year 2016 (C), Upper Femons water year 2016 (D). Panel E shows sediment yields versus rill density for each water year. No sediment was produced in Lower Femmons during the part of 2015 water year after logging. 


\section{$\underline{\text { Literature Cited }}$}

Barton, K. (2016). MuMIn: Multi-model inference. R package version 1.15.6. https://CRAN.R-project.org/package=MuMIn

Bates, D., Mächler, M., Bolker, B., \& Walker, S. (2015). Fitting linear mixed-effects models using lme4. Journal of Statistical Software, 67(1), 51.

http://doi.org/10.18637/jss.v067.i01

Benavides-Solorio, J., \& MacDonald, L. H. (2001). Post-fire runoff and erosion from simulated rainfall on small plots, Colorado Front Range. Hydrological Processes, 15(15), 2931-2952. http://doi.org/10.1002/hyp.383

Bennett, S. J., Gordon, L. M., Neroni, V., \& Wells, R. R. (2015). Emergence, persistence, and organization of rill networks on a soil-mantled experimental landscape. Natural Hazards, 79(S1), 7-24. http://doi.org/10.1007/s11069-015-1599-8

Berg, N. H., \& Azuma, D. L. (2010). Bare soil and rill formation following wildfires, fuel reduction treatments, and pine plantations in the southern Sierra Nevada, California, USA. International Journal of Wildland Fire, 19(4), 478. http://doi.org/10.1071/WF07169

Beschta, R. L., Rhodes, J. J., Kauffman, J. B., Gresswell, R. E., Minshall, G. W., Karr, J. R., Perry, D. A., Hauer R. F., Frissell, C. A. (2004). Post-fire management on forested public lands of the western United States. Conservation Biology, 18(4), 957-967.

doi:10.1111/j.1523-1739.2004.00495.x

Blake, W. H., Wallbrink, P. J., Wilkinson, S. N., Humphreys, G. S., Doerr, S. H., Shakesby, R. A., \& Tomkins, K. M. (2009). Deriving hillslope sediment budgets in wildfire-affected forests using fallout radionuclide tracers. Geomorphology, 104(3-4), 105-116. http://doi.org/10.1016/j.geomorph.2008.08.004

Bladon, K. D., Emelko, M. B., Silins, U., \& Stone, M. (2014). Wildfire and the future of water supply. Environmental Science \& Technology, 48(16), 8936-8943.

http://doi.org/10.1021/es500130g

California Department of Forestry and Fire Protection. (2008). Boggs Mountain Demonstration State Forest Draft Management Plan. Sacramento, CA, 91 p. Retrieved September 25, 2016 at http://calfire.ca.gov/resource_mgt/resource_mgt_stateforests_boggsmtn

Chase, E.H., 2006. Effects of a wildfire and salvage logging on hillslope sediment production. M.S. thesis, Colorado State University, Fort Collins, CO, 72p.

Chou, Y.H., S.G. Conard, and P.M. Wohlgemuth. (1994). Analysis of post-fire salvage logging, watershed characteristics, and sedimentation in the Stanislaus National Forest. In Proceedings of ESRI Users Conference. Environmental Systems Research Institute, Redlands, CA, pp. 492-499. 
Croke, J., Hairsine, P., \& Fogarty, P. (2001). Soil recovery from track construction and harvesting changes in surface infiltration, erosion and delivery rates with time. Forest Ecology and Management, 143(1-3), 3-12. http://doi.org/10.1016/S0378-1127(00)005004

Donato, D. C., Fontaine, J. B., Campbell, J. L., Robinson, W. D., Kaufmann, J. B., Law, B. E. (2006). Post-wildfire logging hinders regeneration and increases fire risk. Science, 311(5759), 352-352. http://doi.org/10.1126/science.1122855

Duursma, R., Powell, J. (2016). R Manual: Mixed effects models. Western Sydney University, Hawksbury Institute for the Environment. Retrieved October 12, 2016 from https://www.westernsydney.edu.au/_data/assets/pdf_file/0004/947740/Rmanual_mixede ffects_20160914.pdf

Evans, R. A., \& Love, R. M. (1957). The Step-Point Method of Sampling: A Practical Tool in Range Research. Journal of Range Management, 10(5), 208. http://doi.org/10.2307/3894015

Fernández, C., \& Vega, J. A. (2016). Effects of mulching and post-fire salvage logging on soil erosion and vegetative regrowth in NW Spain. Forest Ecology and Management, 375, 46-54. http://doi.org/10.1016/j.foreco.2016.05.024

Flannigan, M.D., Stocks, B.J., \& Wotton, B.M. (2000). Climate change and forest fires. Science of The Total Environment, 262(3), 221-229. http://doi.org/10.1016/S00489697(00)00524-6

Fox, J., \& Weisberg, S. (2011). An R Companion to Applied Regression, Second Edition. Thousand Oaks CA: Sage. http://socserv.socsci.mcmaster.ca/jfox/Books/Companion

Fried, J. S., Torn, M. S., \& Mills, E. (2004). The impact of climate change on wildfire severity: A regional forecast for northern California. Climatic Change, 64(1/2), 169-191. http://doi.org/10.1023/B:CLIM.0000024667.89579.ed

Gómez, J. A., Darboux, F., \& Nearing, M. A. (2003). Development and evolution of rill networks under simulated rainfall. Water Resources Research, 39(6), 1148. http://doi.org/10.1029/2002WR001437

Gould, G. K., Liu, M., Barber, M. E., Cherkauer, K. A., Robichaud, P. R., \& Adam, J. C. (2016). The effects of climate change and extreme wildfire events on runoff erosion over a mountain watershed. Journal of Hydrology, 536, 74-91.

http://doi.org/10.1016/j.jhydrol.2016.02.025

Halekoh, U., \& Højsgaard, S. (2014). A Kenward-Roger Approximation and Parametric Bootstrap Methods for Tests in Linear Mixed Models - The R Package pbkrtest. Journal of Statistical Software, 59(9), 1-32. http://doi.org/10.18637/jss.v059.i09 
Harrison, N. M., Stubblefield, A. P., Varner, J. M., \& Knapp, E. E. (2016). Finding balance between fire hazard reduction and erosion control in the Lake Tahoe Basin, California-Nevada. Forest Ecology and Management, 360, 40-51.

http://doi.org/10.1016/j.foreco.2015.10.030

Helvey, J. D. (1980). Effects of a north central Washington wildfire on runoff and sediment production. Journal of the American Water Resources Association, 16(4), 627634. http://doi.org/10.1111/j.1752-1688.1980.tb02441.x

Ice, G. G., Neary, D. G., \& Adams, P. W. (2004). Effects of Wildfire on Processes. Journal of Forestry, 102(September), 16-20.

James, C., 2014. Post-wildfire salvage logging, soil erosion, and sediment delivery Ponderosa Fire, Battle Creek Watershed, Northern California, preliminary results. Sierra Pacific Industries, Redding, California.

Kampf, S. K., Brogan, D. J., Schmeer, S., MacDonald, L. H., \& Nelson, P. A. (2016). How do geomorphic effects of rainfall vary with storm type and spatial scale in a postfire landscape? Geomorphology, 273, 39-51. http://doi.org/10.1016/j.geomorph.2016.08.001

Karr, J. R., Rhodes, J. J., Minshall, G. W., Hauer, F. R., Beschta, R. L., Frissell, C. A., \& Perry, D. A. (2004). The effects of postfire salvage logging on aquatic ecosystems in the American West. BioScience, 54(11), 1029. http://doi.org/10.1641/00063568(2004)054[1029:TEOPSL]2.0.CO;2

Lenth, R. V. (2016). Least-squares means: the R package lsmeans. Journal of Statistical Software, 69(1), 1-33. http://doi.org/10.18637/jss.v069.i01

Littell, J. S., Mckenzie, D., Peterson, D. L., \& Westerling, A. L. (2009). Climate and wildfire area burned in western U.S. ecoprovinces, 1916-2003. Ecological Applications, 19(4), 1003-1021. http://doi.org/10.1890/07-1183.1

Larsen, I. J., MacDonald, L. H., Brown, E., Rough, D., Welsh, M. J., Pietraszek, J. H., Libohova, Z., Benavides-Solorio, J., Schaffrath, K. (2009). Causes of post-fire runoff and erosion: water repellency, cover, or soil sealing? Soil Science Society of America Journal, 73(4), 1393. http://doi.org/10.2136/sssaj2007.0432

Lindenmayer, D. B., Foster, D. R., Franklin, J. F., Hunter, M. L., Noss, R. F., Schmiegelow, F. A., \& Perry, D. (2004). Salvage harvesting policies after natural disturbance. Science, 303(5662), 1303-1303. http://doi.org/10.1126/science.1093438

Lindenmayer, D. B., \& Noss, R. F. (2006). Salvage logging, ecosystem processes, and biodiversity conservation. Conservation Biology, 20(4), 949-958.

http://doi.org/10.1111/j.1523-1739.2006.00497.x 
Luce, C. H., \& Black, T. A. (1999). Sediment production from forest roads in western Oregon. Water Resources Research, 35(8), 2561-2570.

http://doi.org/10.1029/1999WR900135

MacDonald, L. H. (2000). Evaluating and Managing Cumulative Effects: Process and Constraints. Environmental Management, 26(3), 299-315.

http://doi.org/10.1007/s002670010088

MacDonald LH, Coe D, Litschert S. (2004). Assessing cumulative watershed effects in the Central Sierra Nevada: hillslope measurements and catchment-scale modeling. In Proceedings of the Sierra Nevada Science Symposium: Science for Management and Conservation. USDA Forest Service General Technical Report, PSW-GTR-193: 149-157

MacDonald, L. H., \& Coe, D. (2007). Influence of headwater streams on downstream reaches in forested areas. Forest Science, 53(2), 148-168.

Martin, D. A., \& Moody, J. A. (2001). Comparison of soil infiltration rates in burned and unburned mountainous watersheds. Hydrological Processes, 15(15), 2893-2903. http://doi.org/10.1002/hyp.380

McIver, J. D., \& Starr, L. (2001). A literature review on the environmental effects of postfire logging. Western Journal of Applied Forestry, 16(4), 159-168.

McIver, J., \& McNeil, R. (2006). Soil disturbance and hill-slope sediment transport after logging of a severely burned site in northeastern Oregon. Western Journal of Applied Forestry, 21(3), 123-133.

Miller, J. D., Safford, H. D., Crimmins, M., \& Thode, A. E. (2009). Quantitative evidence for increasing forest fire severity in the Sierra Nevada and southern Cascade Mountains, California and Nevada, USA. Ecosystems, 12(1), 16-32.

http://doi.org/10.1007/s10021-008-9201-9

Moody, J. A., \& Kinner, D. A. (2006). Spatial structures of stream and hillslope drainage networks following gully erosion after wildfire. Earth Surface Processes and Landforms, 31(3), 319-337. http://doi.org/10.1002/esp.1246

Moody, J. A., \& Martin, D. A. (2009). Synthesis of sediment yields after wildland fire in different rainfall regimes in the western United States. International Journal of Wildland Fire, 18(1), 96. http://doi.org/10.1071/WF07162

Moody, J. A., Shakesby, R. A., Robichaud, P. R., Cannon, S. H., \& Martin, D. A. (2013). Current research issues related to post-wildfire runoff and erosion processes. EarthScience Reviews, 122, 10-37. http://doi.org/10.1016/j.earscirev.2013.03.004

Nyman, P., Sheridan, G. J., Moody, J. A., Smith, H. G., Noske, P. J., \& Lane, P. N. J. (2013). Sediment availability on burned hillslopes. Journal of Geophysical Research: Earth Surface, 118(4), 2451-2467. http://doi.org/10.1002/jgrf.20152 
Pannkuk, C. D., \& Robichaud, P. R. (2003). Effectiveness of needle cast at reducing erosion after forest fires. Water Resources Research, 39(12).

http://doi.org/10.1029/2003WR002318

Parsons, A., Robichaud, P.R., Lewis, S., Napper, C., Clark, J., 2010. Field Guide for Mapping Post-Fire Soil Burn Severity. General Technical Report, RMRS-GTR-243. US Department of Agriculture, Forest Service, Rocky Mountain Research Station, Fort Collins, CO.

Peterson, D. W., Dodson, E. K., \& Harrod, R. J. (2015). Post-fire logging reduces surface woody fuels up to four decades following wildfire. Forest Ecology and Management, 338, 84-91. http://doi.org/10.1016/j.foreco.2014.11.016

Peterson, D. W., \& Dodson, E. K. (2016). Post-fire logging produces minimal persistent impacts on understory vegetation in northeastern Oregon, USA. Forest Ecology and Management, 370, 56-64. http://doi.org/10.1016/j.foreco.2016.04.004

Pietraszek, J. H. (2006), Controls on post-fire erosion at the hillslope scale, Colorado Front Range, M.S. thesis, 124 pp., Colorado State University, Fort Collins, CO.

Poff, R.J., 1989. Compatibility of timber salvage operations with watershed values. In: Berg, N.H. (Ed.), Proceedings of the Symposium on Fire and Watershed Management, 26-28 October 1988, Sacramento. US Department of Agriculture, Forest Service, Sacramento, CA, pp. 137-140.

R Core Team (2016). R: A language and environment for statistical computing. R Foundation for statistical computing, Vienna, Austria .URL https://www.R-project.org/

Reynolds, W. D., \& Elrick, D. E. (1990). Ponded infiltration from a single ring: I. analysis of steady flow. Soil Science Society of America Journal, 54(5), 1233. http://doi.org/10.2136/sssaj1990.03615995005400050006x

Robichaud, P. R. (2000). Fire effects on infiltration rates after prescribed fire in northern Rocky Mountain forests, USA. Journal of Hydrology, 231-232, 220-229. http://doi.org/10.1016/S0022-1694(00)00196-7

Robichaud, P.R., Brown, R.E., 2002. Silt Fences: An Economical Technique for Measuring Hillslope Soil Erosion. General Technical Report, RMRS-GTR-94. US Department of Agriculture, Forest Service, Rocky Mountain Research Station, Fort Collins, CO.

Robichaud, P. R., Wagenbrenner, J. W., Brown, R. E., Wohlgemuth, P. M., \& Beyers, J. L. (2008a). Evaluating the effectiveness of contour-felled log erosion barriers as a postfire runoff and erosion mitigation treatment in the western United States. International Journal of Wildland Fire, 17(2), pp 255. http://doi.org/10.1071/WF07032 
Robichaud, P. R., Pierson, F. B., Brown, R. E., \& Wagenbrenner, J. W. (2008b). Measuring effectiveness of three post-fire hillslope erosion barrier treatments, western Montana, USA. Hydrological Processes, 22(2), 159-170. http://doi.org/10.1002/hyp.6558

Robichaud, P. R., Wagenbrenner, J. W., \& Brown, R. E. (2010). Rill erosion in natural and disturbed forests: 1. Measurements. Water Resources Research, 46(10), W10506. http://doi.org/10.1029/2009WR008314

Robichaud, P. R., Lewis, S. A., Wagenbrenner, J. W., Ashmun, L. E., \& Brown, R. E. (2013a). Post-fire mulching for runoff and erosion mitigation. Catena, 105, 75-92. http://doi.org/10.1016/j.catena.2012.11.015

Robichaud, P. R., Wagenbrenner, J. W., Lewis, S. A., Ashmun, L. E., Brown, R. E., \& Wohlgemuth, P. M. (2013b). Post-fire mulching for runoff and erosion mitigation Part II: Effectiveness in reducing runoff and sediment yields from small catchments. CATENA, 105, 93-111. http://doi.org/10.1016/j.catena.2012.11.016

Robichaud, P. R., Wagenbrenner, J. W., Pierson, F. B., Spaeth, K. E., Ashmun, L. E., \& Moffet, C. A. (2016). Infiltration and interrill erosion rates after a wildfire in western Montana, USA. Catena, 142, 77-88. http://doi.org/10.1016/j.catena.2016.01.027

Shakesby, R.A., \& Doerr, S.H. (2006). Wildfire as a hydrological and geomorphological agent. Earth-Science Reviews, 74(3-4), 269-307.

http://doi.org/10.1016/j.earscirev.2005.10.006

Silins, U., Stone, M., Emelko, M. B., \& Bladon, K. D. (2009). Sediment production following severe wildfire and post-fire salvage logging in the Rocky Mountain headwaters of the Oldman River Basin, Alberta. CATENA, 79(3), 189-197. http://doi.org/10.1016/j.catena.2009.04.001

Soil Survey Staff. (2016). USDA NRCS Web Soil Survey. Retrieved Sept 25, 2016 from http://websoilsurvey.nrcs.usda.gov/.

Slesak, R. A., Schoenholtz, S. H., \& Evans, D. (2015). Hillslope erosion two and three years after wildfire, skyline salvage logging, and site preparation in southern Oregon, USA. Forest Ecology and Management, 342, 1-7.

http://doi.org/10.1016/j.foreco.2015.01.007

Stabenow, J.H., Ulvestad, K.N., Fitz, L., Hardee, V., Howard, G., McClelland, K., Robbins, M.A., Woodward, W.W., \& Sundberg, F.A. (2006). The effects of logging burned wood on soil erosion rates. Hydrology and Water Resources in Arizona and the Southwest, 36, 13-20.

Stavros, E. N., Tane, Z., Kane, V. R., Veraverbeke, S., McGaughey, R. J., Lutz, J. A., Ramirez, C., Schimel, D. (2016). Unprecedented remote sensing data over King and Rim 
Megafires in the Sierra Nevada Mountains of California. Ecology. http://doi.org/10.1002/ecy.1577

Stone, M., Collins, A. L., Silins, U., Emelko, M. B., \& Zhang, Y. S. (2014). The use of composite fingerprints to quantify sediment sources in a wildfire impacted landscape, Alberta, Canada. Science of the Total Environment, 473-474, 642-650. http://doi.org/10.1016/j.scitotenv.2013.12.052

USDA Forest Service. (2014). Final environmental impact statement, Rim Fire Recovery. Stanislaus National Forest, Sonora, CA. 169 pp.

USDA Forest Service. (2016). Vegetation Burn Severity 1985 to 2015, Pacific Southwest Region. Retrieved September 25, 2016 from http://www.fs.usda.gov/detail/r5/landmanagement/gis/?cid=stelprd3805100

US Geological Survey Gap Analysis Program (GAP). (2011). National Land Cover (Version 2). Retrieved September 25, 2016 from http://gapanalysis.usgs.gov/gaplandcover/

Wagenbrenner, J. W., MacDonald, L. H., \& Rough, D. (2006). Effectiveness of three post-fire rehabilitation treatments in the Colorado Front Range. Hydrological Processes, 20(14), 2989-3006. http://doi.org/10.1002/hyp.6146

Wagenbrenner, J. W., Robichaud, P. R., \& Elliot, W. J. (2010). Rill erosion in natural and disturbed forests: 2. Modeling approaches. Water Resources Research, 46, W10507. http://doi.org/10.1029/2009WR008315

Wagenbrenner, J. W., MacDonald, L. H., Coats, R. N., Robichaud, P. R., \& Brown, R. E. (2015). Effects of post-fire salvage logging and a skid trail treatment on ground cover, soils, and sediment production in the interior western United States. Forest Ecology and Management, 335, 176-193. http://doi.org/10.1016/j.foreco.2014.09.016

Wagenbrenner, J. W., Robichaud, P. R., \& Brown, R. E. (2016). Rill erosion in burned and salvage logged western montane forests: Effects of logging equipment type, traffic level, and slash treatment. Journal of Hydrology.

http://doi.org/10.1016/j.jhydrol.2016.07.049

Westerling, A. L., Hidalgo, H.G, Cayan, D.R., \& Swetnam, T. W. (2006). Warming and earlier spring increase western U.S. forest wildfire activity. Science, 313(5789), 940-943. http://doi.org/10.1126/science.1128834

Westerling, A. L., \& Bryant, B. P. (2008). Climate change and wildfire in California. Climatic Change, 87(S1), 231-249. http://doi.org/10.1007/s10584-007-9363-z

Westerling, A. L., Bryant, B. P., Preisler, H. K., Holmes, T. P., Hidalgo, H. G., Das, T., \& Shrestha, S. R. (2011). Climate change and growth scenarios for California wildfire. Climatic Change, 109(S1), 445-463. http://doi.org/10.1007/s10584-011-0329-9 
Western Regional Climate Center. (2016). Cooperative Climatological Data Summaries. Retrieved September 25, 2016 from http://www.wrcc.dri.edu/climatedata/climsum/

Winters, B. (2013). Linear models and linear mixed effects models in R with linguistic applications. arXiv:1308.5499. Retrieved October 15, 2016 from

http://arxiv.org/pdf/1308.5499.pdf 


\section{$\underline{\text { Appendices }}$}

Appendix A: November 2015 ground cover at BMDSF by swale.

\begin{tabular}{ccccccc}
\hline Swale & Date & Vegetation \% & Litter \% & Wood \% & Rock \% & Bare \% \\
\hline Channel 1 & November 2015 & 0 & 49 & 1 & 6 & 45 \\
Channel 2 & November 2015 & 0 & 33 & 2 & 12 & 53 \\
Channel 3 & November 2015 & 0 & 41 & 3 & 7 & 50 \\
Channel 4 & November 2015 & 0 & 13 & 2 & 2 & 84 \\
Channel 5 & November 2015 & 0 & 14 & 2 & 6 & 78 \\
Channel 6 & November 2015 & 0 & 29 & 4 & 1 & 66 \\
\hline
\end{tabular}

实 
Appendix B:_Rainfall events in Boggs Mountain Demonstration State Forest, October 2015 to June 2016. Only trace amounts of rainfall occurred from October to the rain gage installation. No rainfall was recorded between 17 June 2016 and 30 September 2016.

\begin{tabular}{ccccccccc}
\hline Begin & Time & End & Time & $\begin{array}{c}\text { Duration } \\
(\mathrm{min})\end{array}$ & $\begin{array}{c}\text { Depth } \\
(\mathrm{mm})\end{array}$ & $\begin{array}{c}\mathrm{I}_{10} \\
\left(\mathrm{~mm} \mathrm{hr}^{-1}\right)\end{array}$ & $\begin{array}{c}\mathrm{I}_{30} \\
\left(\mathrm{~mm} \mathrm{hr}^{-1}\right)\end{array}$ & $\begin{array}{c}\mathrm{I}_{60} \\
\left(\mathrm{~mm} \mathrm{hr}^{-1}\right)\end{array}$ \\
\hline $11 / 24 / 2015$ & $7: 25$ & $11 / 24 / 2015$ & $10: 28$ & 184 & 5.33 & 6 & 5 & 4 \\
$12 / 3 / 2015$ & $8: 48$ & $12 / 4 / 2015$ & $5: 43$ & 1256 & 37.85 & 15 & 11 & 10 \\
$12 / 6 / 2015$ & $2: 27$ & $12 / 6 / 2015$ & $17: 22$ & 896 & 20.83 & 15 & 8 & 7 \\
$12 / 9 / 2015$ & $0: 10$ & $12 / 11 / 2015$ & $9: 40$ & 3451 & 87.63 & 18 & 14 & 10 \\
$12 / 12 / 2015$ & $21: 25$ & $12 / 13 / 2015$ & $18: 19$ & 1255 & 46.99 & 21 & 17 & 15 \\
$12 / 14 / 2015$ & $10: 53$ & $12 / 14 / 2015$ & $10: 53$ & 1 & 0.51 & 3 & 1 & 1 \\
$12 / 17 / 2015$ & $22: 55$ & $12 / 19 / 2015$ & $5: 02$ & 1808 & 39.88 & 11 & 8 & 6 \\
$12 / 20 / 2015$ & $7: 20$ & $12 / 22 / 2015$ & $19: 38$ & 3619 & 72.64 & 11 & 9 & 8 \\
$12 / 24 / 2015$ & $3: 24$ & $12 / 24 / 2015$ & $14: 35$ & 672 & 10.67 & 8 & 5 & 4 \\
$12 / 28 / 2015$ & $12: 00$ & $12 / 28 / 2015$ & $13: 24$ & 85 & 4.57 & 8 & 5 & 4 \\
$12 / 30 / 2015$ & $6: 53$ & $12 / 30 / 2015$ & $12: 33$ & 341 & 0.76 & 2 & 1 & 1 \\
$1 / 3 / 2016$ & $7: 50$ & $1 / 3 / 2016$ & $11: 52$ & 243 & 6.60 & 6 & 4 & 3 \\
$1 / 3 / 2016$ & $22: 58$ & $1 / 6 / 2016$ & $18: 32$ & 4055 & 154.94 & 12 & 11 & 10 \\
$1 / 8 / 2016$ & $20: 20$ & $1 / 10 / 2016$ & $0: 38$ & 1699 & 14.22 & 5 & 3 & 2 \\
$1 / 11 / 2016$ & $8: 23$ & $1 / 12 / 2016$ & $2: 08$ & 1066 & 4.32 & 3 & 2 & 1 \\
$1 / 12 / 2016$ & $16: 19$ & $1 / 13 / 2016$ & $13: 53$ & 1295 & 62.99 & 15 & 14 & 13 \\
$1 / 14 / 2016$ & $12: 40$ & $1 / 15 / 2016$ & $1: 33$ & 774 & 20.07 & 24 & 12 & 6 \\
$1 / 15 / 2016$ & $19: 30$ & $1 / 16 / 2016$ & $9: 54$ & 865 & 19.81 & 12 & 5 & 12 \\
$1 / 17 / 2016$ & $0: 26$ & $1 / 17 / 2016$ & $21: 33$ & 1268 & 87.38 & 15 & 13 & 10 \\
$1 / 18 / 2016$ & $16: 00$ & $1 / 19 / 2016$ & $13: 11$ & 1272 & 48.01 & 15 & 18 & 12 \\
$1 / 21 / 2016$ & $21: 54$ & $1 / 23 / 2016$ & $18: 37$ & 2684 & 75.69 & & 9
\end{tabular}




\begin{tabular}{|c|c|c|c|c|c|c|c|c|}
\hline $1 / 24 / 2016$ & $22: 59$ & $1 / 25 / 2016$ & $10: 07$ & 669 & 5.33 & 3 & 3 & 2 \\
\hline $1 / 28 / 2016$ & $12: 56$ & $1 / 28 / 2016$ & $14: 12$ & 77 & 1.78 & 5 & 3 & 2 \\
\hline $1 / 28 / 2016$ & $21: 40$ & $1 / 30 / 2016$ & $1: 09$ & 1650 & 11.43 & 6 & 4 & 3 \\
\hline $2 / 2 / 2016$ & $5: 04$ & $2 / 2 / 2016$ & 7:49 & 166 & 1.52 & 2 & 2 & 1 \\
\hline $2 / 3 / 2016$ & $15: 40$ & $2 / 4 / 2016$ & $7: 16$ & 937 & 2.03 & 2 & 1 & 0 \\
\hline $2 / 17 / 2016$ & $13: 10$ & $2 / 19 / 2016$ & $13: 46$ & 2917 & 63.75 & 17 & 13 & 9 \\
\hline $3 / 2 / 2016$ & $23: 06$ & $3 / 2 / 2016$ & $23: 37$ & 32 & 1.27 & 5 & 2 & 1 \\
\hline $3 / 3 / 2016$ & $6: 36$ & $3 / 3 / 2016$ & $11: 47$ & 312 & 1.27 & 2 & 1 & 1 \\
\hline $3 / 4 / 2016$ & $2: 32$ & $3 / 7 / 2016$ & $11: 53$ & 4882 & 245.36 & 37 & 27 & 23 \\
\hline $3 / 8 / 2016$ & $15: 36$ & $3 / 9 / 2016$ & $16: 09$ & 1474 & 5.84 & 5 & 2 & 2 \\
\hline $3 / 10 / 2016$ & $3: 44$ & $3 / 12 / 2016$ & $14: 28$ & 3525 & 190.50 & 21 & 17 & 13 \\
\hline $3 / 12 / 2016$ & $21: 54$ & $3 / 14 / 2016$ & $2: 56$ & 1743 & 64.52 & 12 & 11 & 9 \\
\hline $3 / 20 / 2016$ & $7: 31$ & $3 / 20 / 2016$ & $15: 55$ & 505 & 20.32 & 11 & 8 & 5 \\
\hline $3 / 21 / 2016$ & $3: 00$ & $3 / 21 / 2016$ & $22: 37$ & 1178 & 41.66 & 15 & 10 & 7 \\
\hline $4 / 9 / 2016$ & 11:01 & $4 / 9 / 2016$ & $15: 26$ & 266 & 1.52 & 3 & 2 & 1 \\
\hline $4 / 10 / 2016$ & $0: 35$ & $4 / 10 / 2016$ & $4: 13$ & 219 & 4.06 & 9 & 6 & 4 \\
\hline $4 / 10 / 2016$ & $14: 41$ & $4 / 10 / 2016$ & $14: 53$ & 13 & 0.51 & 2 & 1 & 1 \\
\hline $4 / 13 / 2016$ & $22: 18$ & $4 / 14 / 2016$ & $0: 12$ & 115 & 8.64 & 11 & 8 & 6 \\
\hline $4 / 21 / 2016$ & $15: 06$ & $4 / 22 / 2016$ & $15: 12$ & 1447 & 32.00 & 18 & 13 & 10 \\
\hline $4 / 27 / 2016$ & $6: 58$ & $4 / 27 / 2016$ & $7: 04$ & 7 & 0.76 & 5 & 2 & 1 \\
\hline $4 / 27 / 2016$ & $13: 38$ & $4 / 27 / 2016$ & $14: 21$ & 44 & 2.03 & 5 & 3 & 2 \\
\hline $5 / 4 / 2016$ & $6: 15$ & $5 / 4 / 2016$ & $10: 05$ & 231 & 0.51 & 2 & 1 & 0 \\
\hline $5 / 5 / 2016$ & $8: 20$ & $5 / 5 / 2016$ & $8: 44$ & 25 & 0.76 & 3 & 2 & 1 \\
\hline $5 / 7 / 2016$ & $2: 05$ & $5 / 7 / 2016$ & $8: 18$ & 374 & 1.02 & 2 & 1 & 1 \\
\hline $5 / 7 / 2016$ & $20: 37$ & $5 / 8 / 2016$ & $2: 39$ & 363 & 6.10 & 11 & 5 & 3 \\
\hline $5 / 21 / 2016$ & $12: 13$ & $5 / 21 / 2016$ & $14: 49$ & 157 & 3.05 & 5 & 3 & 2 \\
\hline
\end{tabular}




\begin{tabular}{ccccccccc}
$5 / 23 / 2016$ & $13: 35$ & $5 / 23 / 2016$ & $14: 16$ & 42 & 0.51 & 2 & 1 & 1 \\
$5 / 24 / 2016$ & $15: 33$ & $5 / 24 / 2016$ & $17: 12$ & 100 & 1.02 & 2 & 1 & 1 \\
$6 / 16 / 2016$ & $15: 32$ & $6 / 16 / 2016$ & $16: 41$ & 70 & 0.76 & 3 & 1 & 1 \\
$6 / 17 / 2016$ & $2: 37$ & $6 / 17 / 2016$ & $12: 00$ & 564 & 3.56 & 3 & 2 & 1 \\
$6 / 17 / 2016$ & $20: 27$ & $6 / 18 / 2016$ & $1: 48$ & 322 & 6.10 & 9 & 5 & 3 \\
\hline
\end{tabular}

$\infty$ 
Appendix C: Individual rill measurements in BMDSF, January 2016 and May 2016.

\begin{tabular}{|c|c|c|c|c|c|c|c|}
\hline $\begin{array}{c}\text { Rill } \\
\text { segment } \\
\text { length (m) }\end{array}$ & Swale & $\begin{array}{l}\text { Rill } \\
\text { ID }\end{array}$ & $\begin{array}{l}\text { Flowpath } \\
\text { type }\end{array}$ & $\begin{array}{c}\text { Connected to } \\
\text { outlet }\end{array}$ & $\begin{array}{l}\text { Length to } \\
\text { outlet (m) }\end{array}$ & Burn severity & Survey Date \\
\hline 37.0 & Channel 1 & 1_1 & Channel & Yes & 37.0 & Low & January 2016 \\
\hline 6.1 & Channel 2 & $2 \_1$ & Rill & Yes & 6.1 & Low & January 2016 \\
\hline 15.4 & Channel 3 & $3 \_1$ & Channel & Yes & 15.4 & Moderate & January 2016 \\
\hline 5.5 & Channel 3 & $3 \_2$ & Rill & Yes & 16.3 & Moderate & January 2016 \\
\hline 15.8 & Channel 3 & $3 \_3$ & Rill & Yes & 31.0 & Moderate & January 2016 \\
\hline 8.5 & Channel 3 & $3-4$ & Rill & Yes & 30.9 & Moderate & January 2016 \\
\hline 8.2 & Channel 3 & $3 \_5$ & Rill & Yes & 23.4 & Moderate & January 2016 \\
\hline 9.5 & Channel 3 & $3 \_6$ & Rill & Yes & 34.9 & Moderate & January 2016 \\
\hline 10.2 & Channel 3 & $3 \_7$ & Rill & Yes & 37.4 & Moderate & January 2016 \\
\hline 4.7 & Channel 3 & $3 \_8$ & Rill & Yes & 26.7 & Moderate & January 2016 \\
\hline 4.5 & Channel 3 & 3_9 & Rill & Yes & 5.4 & Moderate & January 2016 \\
\hline 16.2 & Channel 4 & $4 \_1$ & Channel & Yes & 16.2 & High & January 2016 \\
\hline 26.9 & Channel 4 & 4_2 & Rill & Yes & 43.0 & High & January 2016 \\
\hline 17.9 & Channel 4 & $4 \_3$ & Rill & Yes & 34.1 & High & January 2016 \\
\hline 18.1 & Channel 4 & $4 \_4$ & Rill & Yes & 41.9 & High & January 2016 \\
\hline 12.8 & Channel 4 & $4 \_5$ & Rill & Yes & 42.3 & High & January 2016 \\
\hline 9.5 & Channel 4 & 4_6 & Rill & Yes & 40.5 & High & January 2016 \\
\hline 10.6 & Channel 4 & $4-7$ & Rill & Yes & 38.3 & High & January 2016 \\
\hline 16.7 & Channel 4 & $4 \_8$ & Rill & Yes & 25.7 & High & January 2016 \\
\hline
\end{tabular}




\begin{tabular}{|c|c|c|c|c|c|c|c|}
\hline 24.6 & Channel 5 & $5 \_1$ & Channel & Yes & 24.6 & High & January 2016 \\
\hline 4.9 & Channel 5 & 5_10 & Rill & Yes & 11.5 & High & January 2016 \\
\hline 26.2 & Channel 5 & 5_11 & Rill & No & 0.0 & High & January 2016 \\
\hline 33.2 & Channel 5 & 52 & Rill & Yes & 57.7 & High & January 2016 \\
\hline 8.4 & Channel 5 & $5 \_3$ & Rill & Yes & 57.0 & High & January 2016 \\
\hline 8.2 & Channel 5 & 5 & Rill & Yes & 58.6 & High & January 2016 \\
\hline 11.4 & Channel 5 & $5 \_5$ & Rill & Yes & 49.5 & High & January 2016 \\
\hline 9.9 & Channel 5 & 5 & Rill & Yes & 33.2 & High & January 2016 \\
\hline 4.2 & Channel 5 & 5 & Rill & Yes & 27.5 & High & January 2016 \\
\hline 2.5 & Channel 5 & 5 & Rill & Yes & 10.0 & High & January 2016 \\
\hline 8.2 & Channel 5 & 5 & Rill & Yes & 16.7 & High & January 2016 \\
\hline 31.4 & Channel 6 & $6 \_1$ & Channel & Yes & 31.4 & Moderate & January 2016 \\
\hline 17.7 & Channel 6 & $6 \_2$ & Rill & Yes & 42.5 & Moderate & January 2016 \\
\hline 7.5 & Channel 6 & $6 \_3$ & Rill & Yes & 36.5 & Moderate & January 2016 \\
\hline 6.5 & Channel 6 & $6 \_4$ & Rill & Yes & 36.1 & Moderate & January 2016 \\
\hline 3.4 & Channel 6 & $6 \_5$ & Rill & Yes & 37.6 & Moderate & January 2016 \\
\hline 46.0 & Channel 1 & $1 \_0$ & Channel & Yes & 46.0 & Low & May 2016 \\
\hline 27.1 & Channel 1 & $1 \_1$ & Rill & Yes & 73.2 & Low & May 2016 \\
\hline 7.7 & Channel 2 & $2 \_1$ & Rill & Yes & 7.7 & Low & May 2016 \\
\hline 20.7 & Channel 3 & 3 & Rill & Yes & 42.0 & Moderate & May 2016 \\
\hline 18.6 & Channel 3 & $3 \_0$ & Channel & Yes & 18.6 & Moderate & May 2016 \\
\hline 2.6 & Channel 3 & $3 \_2$ & Rill & Yes & 17.8 & Moderate & May 2016 \\
\hline 23.9 & Channel 3 & $3 \_3$ & Rill & Yes & 38.0 & Moderate & May 2016 \\
\hline 4.1 & Channel 3 & $3-4$ & Rill & Yes & 28.0 & Moderate & May 2016 \\
\hline 6.7 & Channel 3 & 3 & Rill & Yes & 34.8 & Moderate & May 2016 \\
\hline 2.8 & Channel 3 & $3 \_6$ & Rill & Yes & 16.3 & Moderate & May 2016 \\
\hline
\end{tabular}




\begin{tabular}{|c|c|c|c|c|c|c|c|}
\hline 19.6 & Channel 3 & 3_7 & Rill & Yes & 32.6 & Moderate & May 2016 \\
\hline 15.6 & Channel 3 & $3 \_8$ & Rill & Yes & 41.5 & Moderate & May 2016 \\
\hline 22.6 & Channel 3 & 3_9 & Rill & Yes & 35.4 & Moderate & May 2016 \\
\hline 8.9 & Channel 3 & 3_10 & Rill & Yes & 42.0 & Moderate & May 2016 \\
\hline 6.0 & Channel 3 & 311 & Rill & Yes & 28.7 & Moderate & May 2016 \\
\hline 24.5 & Channel 4 & 4_0 & Channel & Yes & 24.5 & High & May 2016 \\
\hline 28.2 & Channel 4 & 4_1 & Rill & Yes & 93.5 & High & May 2016 \\
\hline 20.5 & Channel 4 & 4_2 & Rill & Yes & 109.1 & High & May 2016 \\
\hline 21.0 & Channel 4 & 43 & Rill & Yes & 83.2 & High & May 2016 \\
\hline 26.7 & Channel 4 & 44 & Rill & Yes & 32.5 & High & May 2016 \\
\hline 39.7 & Channel 4 & $4 \_5$ & Rill & Yes & 46.4 & High & May 2016 \\
\hline 6.6 & Channel 4 & 4_6 & Rill & Yes & 29.0 & High & May 2016 \\
\hline 20.5 & Channel 4 & 4_7 & Rill & Yes & 28.3 & High & May 2016 \\
\hline 10.0 & Channel 4 & $4 \_8$ & Rill & Yes & 21.7 & High & May 2016 \\
\hline 17.6 & Channel 4 & 4_9 & Rill & Yes & 42.9 & High & May 2016 \\
\hline 13.7 & Channel 4 & 4_10 & Rill & Yes & 93.5 & High & May 2016 \\
\hline 13.2 & Channel 4 & 4_12 & Rill & Yes & 44.3 & High & May 2016 \\
\hline 12.3 & Channel 4 & $4-11$ & Rill & Yes & 42.3 & High & May 2016 \\
\hline 10.5 & Channel 4 & $4 \_13$ & Rill & Yes & 45.2 & High & May 2016 \\
\hline 4.2 & Channel 4 & 4_14 & Rill & Yes & 40.2 & High & May 2016 \\
\hline 7.8 & Channel 4 & 4_15 & Rill & Yes & 46.8 & High & May 2016 \\
\hline 15.4 & Channel 4 & 4_16 & Rill & Yes & 52.3 & High & May 2016 \\
\hline 5.5 & Channel 4 & 4_17 & Rill & Yes & 51.5 & High & May 2016 \\
\hline 29.3 & Channel 4 & 4_18 & Rill & Yes & 61.1 & High & May 2016 \\
\hline 15.5 & Channel 4 & 4_19 & Rill & Yes & 50.2 & High & May 2016 \\
\hline 19.1 & Channel 4 & 4_20 & Rill & Yes & 109.1 & High & May 2016 \\
\hline
\end{tabular}




$\begin{array}{cccccccc}23.7 & \text { Channel 4 } & 4 \_21 & \text { Rill } & \text { Yes } & 52.3 & \text { High } & \text { May 2016 } \\ 11.6 & \text { Channel 4 } & 4 \_22 & \text { Rill } & \text { Yes } & 39.1 & \text { High } & \text { May 2016 } \\ 14.6 & \text { Channel 4 } & 4 \_23 & \text { Rill } & \text { Yes } & 41.0 & \text { High } & \text { May 2016 } \\ 6.4 & \text { Channel 4 } & 4 \_24 & \text { Rill } & \text { Yes } & 32.8 & \text { High } & \text { May 2016 } \\ 15.5 & \text { Channel 4 } & 4 \_25 & \text { Rill } & \text { Yes } & 40.3 & \text { High } & \text { May 2016 } \\ 13.6 & \text { Channel 4 } & 4 \_26 & \text { Rill } & \text { Yes } & 30.6 & \text { High } & \text { May 2016 } \\ 5.2 & \text { Channel 4 } & 4 \_27 & \text { Rill } & \text { Yes } & 25.0 & \text { High } & \text { May 2016 } \\ 10.6 & \text { Channel 4 } & 4 \_28 & \text { Rill } & \text { Yes } & 25.7 & \text { High } & \text { May 2016 } \\ 10.7 & \text { Channel 4 } & 4 \_29 & \text { Rill } & \text { No } & 0.0 & \text { High } & \text { May 2016 } \\ 6.3 & \text { Channel 4 } & 4 \_39 & \text { Rill } & \text { Yes } & 21.0 & \text { High } & \text { May 2016 } \\ 35.9 & \text { Channel 4 } & 4 \_30 & \text { Rill } & \text { Yes } & 83.2 & \text { High } & \text { May 2016 } \\ 7.4 & \text { Channel 4 } & 4 \_31 & \text { Rill } & \text { Yes } & 16.7 & \text { High } & \text { May 2016 } \\ 8.2 & \text { Channel 4 } & 4 \_32 & \text { Rill } & \text { Yes } & 17.0 & \text { High } & \text { May 2016 } \\ 15.2 & \text { Channel 4 } & 4 \_33 & \text { Rill } & \text { Yes } & 23.6 & \text { High } & \text { May 2016 } \\ 32.6 & \text { Channel 4 } & 4 \_34 & \text { Rill } & \text { Yes } & 38.0 & \text { High } & \text { May 2016 } \\ 10.8 & \text { Channel 4 } & 4 \_35 & \text { Rill } & \text { Yes } & 15.6 & \text { High } & \text { May 2016 } \\ 49.0 & \text { Channel 4 } & 4 \_36 & \text { Rill } & \text { Yes } & 47.9 & \text { High } & \text { May 2016 } \\ 48.5 & \text { Channel 4 } & 4 \_37 & \text { Rill } & \text { Yes } & 50.7 & \text { High } & \text { May 2016 } \\ 10.5 & \text { Channel 4 } & 4 \_38 & \text { Rill } & \text { Yes } & 11.9 & \text { High } & \text { May 2016 } \\ 18.3 & \text { Channel 5 } & 5 \_1 & \text { Rill } & \text { Yes } & 52.8 & \text { High } & \text { May 2016 } \\ 15.5 & \text { Channel 5 } & 5 \_2 & \text { Rill } & \text { Yes } & 81.9 & \text { High } & \text { May 2016 } \\ 23.0 & \text { Channel 5 } & 5 \_0 & \text { Rill } & \text { Yes } & 24.2 & \text { High } & \text { May 2016 } \\ 30.0 & \text { Channel 5 } & 5 \_3 & \text { Rill } & \text { Yes } & 32.5 & \text { High } & \text { May 2016 } \\ 3.5 & \text { Channel 5 } & 5 \_4 & \text { Rill } & \text { Yes } & 4.9 & \text { High } & \text { May 2016 } \\ 5.3 & \text { Channel 5 } & 5 \_5 & \text { Rill } & \text { Yes } & 7.9 & \text { High } & \text { May 2016 } \\ 3.2 & \text { Channel 5 } & 5 \_6 & \text { Rill } & \text { Yes } & 6.8 & \text { High } & \text { May 2016 }\end{array}$




$\begin{array}{cccccccc}7.0 & \text { Channel 5 } & 5 \_7 & \text { Rill } & \text { Yes } & 27.0 & \text { High } & \text { May 2016 } \\ 5.8 & \text { Channel 5 } & 5 \_8 & \text { Rill } & \text { Yes } & 27.9 & \text { High } & \text { May 2016 } \\ 7.0 & \text { Channel 5 } & 5 \_9 & \text { Rill } & \text { Yes } & 29.6 & \text { High } & \text { May 2016 } \\ 9.3 & \text { Channel 5 } & 5 \_10 & \text { Rill } & \text { Yes } & 52.8 & \text { High } & \text { May 2016 } \\ 34.0 & \text { Channel 5 } & 5 \_11 & \text { Rill } & \text { Yes } & 56.0 & \text { High } & \text { May 2016 } \\ 6.1 & \text { Channel 5 } & 5 \_12 & \text { Rill } & \text { Yes } & 38.8 & \text { High } & \text { May 2016 } \\ 27.4 & \text { Channel 5 } & 5 \_13 & \text { Rill } & \text { Yes } & 51.9 & \text { High } & \text { May 2016 } \\ 15.3 & \text { Channel 5 } & 5 \_14 & \text { Rill } & \text { Yes } & 49.6 & \text { High } & \text { May 2016 } \\ 6.5 & \text { Channel 5 } & 5 \_15 & \text { Rill } & \text { Yes } & 47.4 & \text { High } & \text { May 2016 } \\ 44.3 & \text { Channel 5 } & 5 \_16 & \text { Rill } & \text { Yes } & 80.6 & \text { High } & \text { May 2016 } \\ 14.7 & \text { Channel 5 } & 5-17 & \text { Rill } & \text { Yes } & 76.9 & \text { High } & \text { May 2016 } \\ 30.0 & \text { Channel 5 } & 5 \_18 & \text { Rill } & \text { Yes } & 81.0 & \text { High } & \text { May 2016 } \\ 14.4 & \text { Channel 5 } & 5 \_19 & \text { Rill } & \text { Yes } & 81.2 & \text { High } & \text { May 2016 } \\ 10.0 & \text { Channel 5 } & 5 \_20 & \text { Rill } & \text { Yes } & 76.8 & \text { High } & \text { May 2016 } \\ 5.0 & \text { Channel 5 } & 5 \_21 & \text { Rill } & \text { Yes } & 81.9 & \text { High } & \text { May 2016 } \\ \text { 5.1 } & \text { Channel 5 } & 5 \_22 & \text { Rill } & \text { Yes } & 57.8 & \text { High } & \text { May 2016 } \\ 7.1 & \text { Channel 5 } & 5-23 & \text { Channel } & \text { Yes } & 37.4 & \text { High } & \text { May 2016 } \\ 37.4 & \text { Channel 6 } & 6 \_0 & \text { Channel } & \text { Yes } & 39.5 & \text { Moderate } & \text { May 2016 } \\ 39.5 & \text { Channel 6 } & 6 \_1 & \text { Rill } & \text { Yes } & 40.3 & \text { Moderate } & \text { May 2016 } \\ 5.0 & \text { Channel 6 } & 6 \_2 & \text { Rill } & \text { Yes } & 39.5 & \text { Moderate } & \text { May 2016 } \\ 5.1 & \text { Channel 6 } & 6 \_3 & \text { Rill } & \text { Yes } & 39.5 & \text { Moderate } & \text { May 2016 } \\ 10.6 & & & & & & \end{array}$


Appendix D: Sediment yield at BMDSF by clean out date.

\begin{tabular}{ccc}
\hline Swale & Clean out date & Yield $\left(\mathrm{Mg} \mathrm{ha}^{-1}\right)$ \\
\hline Channel 1 & $3 / 4 / 2016$ & 0.0 \\
Channel 2 & $3 / 4 / 2016$ & 0.72 \\
Channel 3 & $3 / 4 / 2016$ & 0.05 \\
Channel 4 & $3 / 4 / 2016$ & 5.15 \\
Channel 5 & $3 / 4 / 2016$ & 2.56 \\
Channel 6 & $3 / 4 / 2016$ & 1.26 \\
Channel 1 & $4 / 8 / 2016$ & 0.0 \\
Channel 2 & $4 / 8 / 2016$ & 0.0 \\
Channel 3 & $4 / 8 / 2016$ & 0.75 \\
Channel 4 & $4 / 8 / 2016$ & 9.87 \\
Channel 5 & $4 / 8 / 2016$ & 10.4 \\
Channel 6 & $4 / 8 / 2016$ & 2.09 \\
Channel 1 & $6 / 1 / 2016$ & 0.05 \\
Channel 2 & $6 / 1 / 2016$ & 0.49 \\
Channel 3 & $6 / 1 / 2016$ & 0.04 \\
Channel 4 & $6 / 1 / 2016$ & 0.20 \\
Channel 5 & $6 / 1 / 2016$ & 0.45 \\
Channel 6 & $6 / 1 / 2016$ & 0.08 \\
\hline
\end{tabular}


Appendix E: Post-salvage logging disturbance in the Rim Fire swales. Femmons is abbreviated by "FSW" for the Lower and Upper units.

\begin{tabular}{|c|c|c|c|c|c|c|c|c|c|}
\hline Swale & Treatment & Unit & $\begin{array}{l}\text { High traffic } \\
\text { skid trail \% }\end{array}$ & $\begin{array}{l}\text { Low traffic } \\
\text { skid trail \% }\end{array}$ & $\begin{array}{c}\text { Feller } \\
\text { Buncher \% }\end{array}$ & $\begin{array}{c}\text { Mixed } \\
\text { traffic } \%\end{array}$ & $\begin{array}{c}2016 \\
\text { Subsoil \% }\end{array}$ & $\begin{array}{l}\text { Waterbar } \\
\text { distance to } \\
\text { outlet (m) }\end{array}$ & $\begin{array}{c}\text { Total } \\
\text { waterbars }\end{array}$ \\
\hline 1 & Logged & Triple A & 14 & 8 & 0 & 4 & 0 & 61 & 2 \\
\hline 2 & Control & Triple A & 0 & 0 & 0 & 0 & 0 & 0 & 0 \\
\hline 3 & Logged & Triple A & 21 & 4 & 1 & 18 & 13 & 35 & 4 \\
\hline 4 & Logged & Triple A & 9 & 11 & 3 & 18 & 0 & 77 & 2 \\
\hline 5 & Logged & Triple A & 28 & 11 & 1 & 0 & 0 & 29 & 4 \\
\hline 6 & Logged & Triple A & 14 & 13 & 2 & 0 & 0 & 48 & 3 \\
\hline 7 & Control & Triple A & 0 & 0 & 0 & 0 & 0 & 0 & 0 \\
\hline 8 & Control & Lower FSW & 0 & 0 & 0 & 0 & 0 & 0 & 0 \\
\hline 9 & Logged & Lower FSW & 15 & 0 & 6 & 0 & 0 & 32 & 3 \\
\hline 10 & Logged & Lower FSW & 29 & 0 & 1 & 26 & 12 & 69 & 3 \\
\hline 11 & Logged & Lower FSW & 12 & 1 & 4 & 0 & 0 & 72 & 2 \\
\hline 12 & Control & Upper FSW & 0 & 0 & 0 & 0 & 0 & 0 & 0 \\
\hline 13 & Logged & Upper FSW & 8 & 1 & 0 & 0 & 0 & 85 & 2 \\
\hline 14 & Control & Upper FSW & 0 & 0 & 0 & 0 & 0 & 0 & 0 \\
\hline
\end{tabular}


Appendix F: Post-salvage bulk density values for each disturbance class and swale in the Rim Fire.

\begin{tabular}{ccccc}
\hline Swale & Disturbance class & Bulk density $\left(\mathrm{g} \mathrm{cm}^{-3}\right)$ & Depth & Unit \\
\hline ASW 1 & High Traffic Skid & 0.97 & $0-5 \mathrm{~cm}$ & Triple A \\
ASW 1 & Low Traffic Skid & 1.21 & $0-5 \mathrm{~cm}$ & Triple A \\
ASW 1 & Feller Buncher & 1.27 & $0-5 \mathrm{~cm}$ & Triple A \\
ASW 1 & Mixed & 1.36 & $0-5 \mathrm{~cm}$ & Triple A \\
ASW 1 & Untrafficked & 1.23 & $0-5 \mathrm{~cm}$ & Triple A \\
ASW 2 & Untrafficked & 1.28 & $0-5 \mathrm{~cm}$ & Triple A \\
ASW 3 & High Traffic Skid & 1.33 & $0-5 \mathrm{~cm}$ & Triple A \\
ASW 3 & Low Traffic Skid & 1.21 & $0-5 \mathrm{~cm}$ & Triple A \\
ASW 3 & Feller Buncher & 1.36 & $0-5 \mathrm{~cm}$ & Triple A \\
ASW 3 & Mixed & 1.31 & $0-5 \mathrm{~cm}$ & Triple A \\
ASW 3 & Untrafficked & 1.08 & $0-5 \mathrm{~cm}$ & Triple A \\
ASW 4 & High Traffic Skid & 1.22 & $0-5 \mathrm{~cm}$ & Triple A \\
ASW 4 & Low Traffic Skid & 1.46 & $0-5 \mathrm{~cm}$ & Triple A \\
ASW 4 & Feller Buncher & 1.45 & $0-5 \mathrm{~cm}$ & Triple A \\
ASW 4 & Mixed & 1.45 & $0-5 \mathrm{~cm}$ & Triple A \\
ASW 4 & Untrafficked & 1.13 & $0-5 \mathrm{~cm}$ & Triple A \\
ASW 5 & High Traffic Skid & 1.68 & $0-5 \mathrm{~cm}$ & Triple A \\
ASW 5 & Low Traffic Skid & 1.50 & $0-5 \mathrm{~cm}$ & Triple A \\
ASW 5 & Feller Buncher & 1.41 & $0-5 \mathrm{~cm}$ & Triple A \\
ASW 5 & Mixed & $0-5 \mathrm{~cm}$ & Triple A \\
ASW 5 & Untrafficked & $0-5 \mathrm{~cm}$ & Triple A \\
ASW 6 & High Traffic Skid & 1.60 & $0-5 \mathrm{~cm}$ & Triple A \\
ASW 6 & Low Traffic Skid & 1.50 & $0-5 \mathrm{~cm}$ & Triple A
\end{tabular}




$\begin{array}{ccccc}\text { ASW 6 } & \text { Feller Buncher } & 1.27 & 0-5 \mathrm{~cm} & \text { Triple A } \\ \text { ASW 6 } & \text { Untrafficked } & 1.20 & 0-5 \mathrm{~cm} & \text { Triple A } \\ \text { ASW 7 } & \text { Untrafficked } & 1.12 & 0-5 \mathrm{~cm} & \text { Triple A } \\ \text { FSW 8 } & \text { Untrafficked } & 1.20 & 0-5 \mathrm{~cm} & \text { Lower Femmons } \\ \text { FSW 9 } & \text { High Traffic Skid } & 1.59 & 0-5 \mathrm{~cm} & \text { Lower Femmons } \\ \text { FSW 9 } & \text { Feller Buncher } & 1.18 & 0-5 \mathrm{~cm} & \text { Lower Femmons } \\ \text { FSW 9 } & \text { Untrafficked } & 1.15 & 0-5 \mathrm{~cm} & \text { Lower Femmons } \\ \text { FSW 10 } & \text { High Traffic Skid } & 1.38 & 0-5 \mathrm{~cm} & \text { Lower Femmons } \\ \text { FSW 10 } & \text { Feller Buncher } & \text { NA } & 0-5 \mathrm{~cm} & \text { Lower Femmons } \\ \text { FSW 10 } & \text { Mixed } & 1.11 & 0-5 \mathrm{~cm} & \text { Lower Femmons } \\ \text { FSW 10 } & \text { Untrafficked } & 1.15 & 0-5 \mathrm{~cm} & \text { Lower Femmons } \\ \text { FSW 11 } & \text { High Traffic Skid } & 1.15 & 0-5 \mathrm{~cm} & \text { Lower Femmons } \\ \text { FSW 11 } & \text { Low Traffic Skid } & 1.01 & 0-5 \mathrm{~cm} & \text { Lower Femmons } \\ \text { FSW 11 } & \text { Feller Buncher } & 1.17 & 0-5 \mathrm{~cm} & \text { Lower Femmons } \\ \text { FSW 11 } & \text { Mixed } & 1.16 & 0-5 \mathrm{~cm} & \text { Lower Femmons } \\ \text { FSW 11 } & \text { Untrafficked } & 1.01 & 0-5 \mathrm{~cm} & \text { Lower Femmons } \\ \text { FSW 13 } & \text { Low Traffic Skid } & 1.12 & 0-5 \mathrm{~cm} & \text { Upper Femmons } \\ \text { FSW 13 } & \text { High Traffic Skid } & 1.13 & 0-5 \mathrm{~cm} & \text { Upper Femmons } \\ \text { FSW 13 } & \text { High Traffic Skid } & 1.13 & 0-5 \mathrm{~cm} & \text { Upper Femmons } \\ \text { ASW 1 } & \text { High Traffic Skid } & 1.42 & 5-10 \mathrm{~cm} & \text { Triple A } \\ \text { ASW 1 } & \text { Low Traffic Skid } & 1.26 & 5-10 \mathrm{~cm} & \text { Triple A } \\ \text { ASW 1 } & \text { Feller Buncher } & 1.15 & 5-10 \mathrm{~cm} & \text { Triple A } \\ \text { ASW 1 } & \text { Mixed } & 1.39 & 5-10 \mathrm{~cm} & \text { Triple A } \\ \text { ASW 1 } & \text { Untrafficked } & 1.31 & 5-10 \mathrm{~cm} & \text { Triple A } \\ \text { ASW 2 } & \text { Untrafficked } & 1.39 & 5-10 \mathrm{~cm} & \text { Triple A } \\ \text { ASW 3 } & \text { High Traffic Skid } & 1.49 & 5-10 \mathrm{~cm} & \text { Triple A }\end{array}$




$\begin{array}{ccccc}\text { ASW 3 } & \text { Low Traffic Skid } & 1.42 & 5-10 \mathrm{~cm} & \text { Triple A } \\ \text { ASW 3 } & \text { Feller Buncher } & 1.31 & 5-10 \mathrm{~cm} & \text { Triple A } \\ \text { ASW 3 } & \text { Mixed } & 1.46 & 5-10 \mathrm{~cm} & \text { Triple A } \\ \text { ASW 3 } & \text { Untrafficked } & 1.20 & 5-10 \mathrm{~cm} & \text { Triple A } \\ \text { ASW 4 } & \text { High Traffic Skid } & 1.69 & 5-10 \mathrm{~cm} & \text { Triple A } \\ \text { ASW 4 } & \text { Low Traffic Skid } & 1.50 & 5-10 \mathrm{~cm} & \text { Triple A } \\ \text { ASW 4 } & \text { Feller Buncher } & 1.40 & 5-10 \mathrm{~cm} & \text { Triple A } \\ \text { ASW 4 } & \text { Mixed } & 1.55 & 5-10 \mathrm{~cm} & \text { Triple A } \\ \text { ASW 4 } & \text { Untrafficked } & 1.21 & 5-10 \mathrm{~cm} & \text { Triple A } \\ \text { ASW 5 } & \text { High Traffic Skid } & 1.65 & 5-10 \mathrm{~cm} & \text { Triple A } \\ \text { ASW 5 } & \text { Low Traffic Skid } & 1.62 & 5-10 \mathrm{~cm} & \text { Triple A } \\ \text { ASW 5 } & \text { Feller Buncher } & 1.39 & 5-10 \mathrm{~cm} & \text { Triple A } \\ \text { ASW 5 } & \text { Mixed } & 1.58 & 5-10 \mathrm{~cm} & \text { Triple A } \\ \text { ASW 5 } & \text { Untrafficked } & 1.26 & 5-10 \mathrm{~cm} & \text { Triple A } \\ \text { ASW 6 } & \text { High Traffic Skid } & 1.59 & 5-10 \mathrm{~cm} & \text { Triple A } \\ \text { ASW 6 } & \text { Low Traffic Skid } & 1.36 & 5-10 \mathrm{~cm} & \text { Triple A } \\ \text { ASW 6 } & \text { Feller Buncher } & 1.39 & 5-10 \mathrm{~cm} & \text { Triple A } \\ \text { ASW 6 } & \text { Untrafficked } & 1.17 & 5-10 \mathrm{~cm} & \text { Triple A } \\ \text { ASW 7 } & \text { Untrafficked } & 1.22 & 5-10 \mathrm{~cm} & \text { Triple A } \\ \text { FSW 8 } & \text { Untrafficked } & 1.20 & 5-10 \mathrm{~cm} & \text { Lower Femmons } \\ \text { FSW 9 } & \text { High Traffic Skid } & 1.55 & 5-10 \mathrm{~cm} & \text { Lower Femmons } \\ \text { FSW 9 } & \text { Feller Buncher } & 1.44 & 5-10 \mathrm{~cm} & \text { Lower Femmons } \\ \text { FSW 9 } & \text { Untrafficked } & 1.08 & 5-10 \mathrm{~cm} & \text { Lower Femmons } \\ \text { FSW 10 } & \text { High Traffic Skid } & 1.38 & 5-10 \mathrm{~cm} & \text { Lower Femmons } \\ \text { FSW 10 } & \text { Feller Buncher } & 1.27 & 5-10 \mathrm{~cm} & \text { Lower Femmons } \\ \text { FSW 10 } & \text { Mixed } & 1.25 & 5-10 \mathrm{~cm} & \text { Lower Femmons } \\ & & & & \end{array}$




\begin{tabular}{ccccl} 
FSW 10 & Untrafficked & 1.19 & $5-10 \mathrm{~cm}$ & Lower Femmons \\
FSW 11 & High Traffic Skid & 1.23 & $5-10 \mathrm{~cm}$ & Lower Femmons \\
FSW 11 & Low Traffic Skid & 1.12 & $5-10 \mathrm{~cm}$ & Lower Femmons \\
FSW 11 & Feller Buncher & 1.34 & $5-10 \mathrm{~cm}$ & Lower Femmons \\
FSW 11 & Mixed & 1.23 & $5-10 \mathrm{~cm}$ & Lower Femmons \\
FSW 11 & Untrafficked & 1.26 & $5-10 \mathrm{~cm}$ & Lower Femmons \\
FSW 13 & Low Traffic Skid & 1.07 & $5-10 \mathrm{~cm}$ & Upper Femmons \\
FSW 13 & High Traffic Skid & 1.12 & $5-10 \mathrm{~cm}$ & Upper Femmons \\
FSW 13 & High Traffic Skid & 1.28 & $5-10 \mathrm{~cm}$ & Upper Femmons \\
\hline
\end{tabular}

$\overline{8}$ 
Appendix G: Post-salvage field saturated hydraulic conductivity (KFS) measurements for each disturbance class and swale in the Rim Fire.

\begin{tabular}{cccc}
\hline Swale & KFS $\left(\mathrm{cm} \mathrm{s}^{-1}\right)$ & Treatment & Unit \\
\hline FSW8 & 0.0077 & Untrafficked & Lower Femmons \\
FSW9 & 0.0118 & Untrafficked & Lower Femmons \\
FSW9 & 0.0017 & Feller Buncher & Lower Femmons \\
FSW9 & 0.0001 & High Traffic Skid & Lower Femmons \\
FSW10 & 0.0120 & Untrafficked & Lower Femmons \\
FSW10 & 0.0017 & Feller Buncher & Lower Femmons \\
FSW10 & 0.0003 & High Traffic Skid & Lower Femmons \\
FSW10 & 0.0007 & Mixed & Lower Femmons \\
FSW11 & 0.0470 & Untrafficked & Lower Femmons \\
FSW11 & 0.0032 & Feller Buncher & Lower Femmons \\
FSW11 & 0.0004 & High Traffic Skid & Lower Femmons \\
FSW11 & 0.0004 & Low Traffic Skid & Lower Femmons \\
FSW11 & 0.0015 & Mixed & Lower Femmons \\
ASW1 & 0.0104 & Untrafficked & Triple A \\
ASW1 & 0.0013 & Low Traffic Skid & Triple A \\
ASW1 & 0.0017 & High Traffic Skid & Triple A \\
ASW1 & 0.0039 & Mixed & Triple A \\
ASW2 & 0.0087 & Untrafficked & Triple A \\
ASW3 & 0.0055 & Untrafficked & Triple A \\
ASW3 & 0.0003 & Feller Buncher & Triple A \\
ASW3 & 0.0042 & Low Traffic Skid & Triple A \\
ASW3 & 0.0003 & High Traffic Skid & Triple A \\
ASW3 & 0.0021 & Mixed & Triple A \\
& & &
\end{tabular}




\begin{tabular}{cccc} 
ASW4 & 0.0057 & Untrafficked & Triple A \\
ASW4 & 0.0035 & Feller Buncher & Triple A \\
ASW4 & 0.0047 & Low Traffic Skid & Triple A \\
ASW4 & 0.0008 & High Traffic Skid & Triple A \\
ASW4 & 0.0012 & Mixed & Triple A \\
ASW5 & 0.0100 & Untrafficked & Triple A \\
ASW5 & 0.0032 & Feller Buncher & Triple A \\
ASW5 & 0.0076 & Low Traffic Skid & Triple A \\
ASW5 & 0.0005 & High Traffic Skid & Triple A \\
ASW5 & 0.0004 & Mixed & Triple A \\
ASW6 & 0.0134 & Untrafficked & Triple A \\
ASW6 & 0.0025 & Feller Buncher & Triple A \\
ASW6 & 0.0033 & Low Traffic Skid & Triple A \\
ASW6 & 0.0003 & High Traffic Skid & Triple A \\
ASW7 & 0.0069 & Untrafficked & Triple A \\
FSW14 & 0.0293 & Untrafficked & Upper Femmons \\
FSW14 & 0.0272 & Untrafficked & Upper Femmons \\
FSW13 & 0.0033 & Low Traffic Skid & Upper Femmons \\
FSW13 & 0.0022 & High Traffic Skid & Upper Femmons \\
FSW13 & 0.0046 & Untrafficked & Upper Femmons \\
FSW12 & 0.0034 & Untrafficked & Upper Femmons \\
FSW12 & 0.0098 & Untrafficked & Upper Femmons \\
\hline
\end{tabular}


Appendix H: Post-salvage disturbance class percent surface cover.

\begin{tabular}{|c|c|c|c|c|c|c|c|c|c|}
\hline Year & Unit & Swale & Treatment & Soil & Litter & Veg & Wood & Rock & $\begin{array}{l}\text { Total } \\
\text { Cover }\end{array}$ \\
\hline 2015 & Triple A & ASW 1 & Mixed Traffic & 23 & 30 & 14 & 33 & 0 & 77 \\
\hline 2015 & Triple A & ASW 1 & Low Traffic Skid & 29 & 35 & 19 & 10 & 7 & 71 \\
\hline 2015 & Triple A & ASW 1 & High Traffic Skid & 51 & 38 & 5 & 5 & 1 & 49 \\
\hline 2015 & Triple A & ASW 3 & Mixed Traffic & 6 & 35 & 0 & 59 & 1 & 94 \\
\hline 2015 & Triple A & ASW 3 & Feller buncher & 59 & 19 & 5 & 17 & 0 & 41 \\
\hline 2015 & Triple A & ASW 3 & Low Traffic Skid & 64 & 20 & 4 & 13 & 0 & 36 \\
\hline 2015 & Triple A & ASW 3 & High Traffic Skid & 66 & 24 & 1 & 8 & 0 & 34 \\
\hline 2015 & Triple A & ASW 4 & Mixed Traffic & 29 & 32 & 21 & 19 & 0 & 71 \\
\hline 2015 & Triple A & ASW 4 & Feller buncher & 38 & 38 & 18 & 6 & 0 & 62 \\
\hline 2015 & Triple A & ASW 4 & Low Traffic Skid & 57 & 26 & 13 & 4 & 0 & 43 \\
\hline 2015 & Triple A & ASW 4 & High Traffic Skid & 75 & 17 & 1 & 7 & 0 & 25 \\
\hline 2015 & Triple A & ASW 5 & Mixed Traffic & 66 & 10 & 21 & 4 & 0 & 34 \\
\hline 2015 & Triple A & ASW 5 & Feller buncher & 56 & 11 & 22 & 11 & 0 & 44 \\
\hline 2015 & Triple A & ASW 5 & Low Traffic Skid & 73 & 9 & 8 & 10 & 0 & 27 \\
\hline 2015 & Triple A & ASW 5 & High Traffic Skid & 62 & 20 & 5 & 14 & 0 & 38 \\
\hline 2015 & Triple A & ASW 6 & Feller buncher & 53 & 18 & 14 & 15 & 0 & 47 \\
\hline 2015 & Triple A & ASW 6 & Low Traffic Skid & 54 & 16 & 15 & 15 & 0 & 46 \\
\hline 2015 & Triple A & ASW 6 & High Traffic Skid & 67 & 17 & 11 & 5 & 0 & 33 \\
\hline 2015 & Lower Femmons & FSW 9 & Feller buncher & 51 & 47 & 0 & 1 & 0 & 49 \\
\hline 2015 & Lower Femmons & FSW 9 & High Traffic Skid & 67 & 29 & 1 & 4 & 0 & 33 \\
\hline 2015 & Lower Femmons & FSW 9 & Untrafficked & 48 & 49 & 1 & 2 & 0 & 52 \\
\hline 2015 & Lower Femmons & FSW 10 & Mixed Traffic & 57 & 25 & 1 & 17 & 0 & 43 \\
\hline 2015 & Lower Femmons & FSW 10 & Feller buncher & 65 & 32 & 1 & 2 & 0 & 35 \\
\hline
\end{tabular}




\begin{tabular}{ccc}
2015 & Lower Femmons & FSW 10 \\
2015 & Lower Femmons & FSW 10 \\
2015 & Lower Femmons & FSW 11 \\
2015 & Lower Femmons & FSW 11 \\
2015 & Lower Femmons & FSW 11 \\
2015 & Lower Femmons & FSW 11 \\
2015 & Lower Femmons & FSW 11 \\
2015 & Upper Femmons & FSW 13 \\
2015 & Upper Femmons & FSW 13 \\
2016 & Triple A & ASW 1 \\
2016 & Triple A & ASW 1 \\
2016 & Triple A & ASW 1 \\
2016 & Triple A & ASW 1 \\
\hline 2016 & Triple A & ASW 3 \\
\hline$\vec{\omega} 2016$ & Triple A & ASW 3 \\
2016 & Triple A & ASW 3 \\
2016 & Triple A & ASW 3 \\
2016 & Triple A & ASW 3 \\
2016 & Triple A & ASW 3 \\
2016 & Triple A & ASW 4 \\
2016 & Triple A & ASW 4 \\
2016 & Triple A & ASW 4 \\
2016 & Triple A & ASW 4 \\
2016 & Triple A & ASW 4 \\
2016 & Triple A & ASW 5 \\
2016 & Triple A & ASW 5
\end{tabular}
High Traffic Skid
Untrafficked
Mixed Traffic
Feller buncher
Low Traffic Skid
High Traffic Skid
Untrafficked
Low Traffic Skid
High Traffic Skid
Mixed Traffic
Low Traffic Skid
High Traffic Skid
Untrafficked
Mixed Traffic
Feller buncher
Low Traffic Skid
High Traffic Skid Subsoil
Untrafficked
Mixed Traffic
Feller buncher
Low Traffic Skid
High Traffic Skid
Untrafficked
Feller buncher
Low Traffic Skid

$\begin{array}{cccccc}73 & 24 & 0 & 3 & 0 & 27 \\ 39 & 59 & 0 & 2 & 0 & 61 \\ 42 & 40 & 0 & 18 & 0 & 58 \\ 43 & 51 & 2 & 4 & 0 & 57 \\ 62 & 36 & 2 & 0 & 0 & 38 \\ 59 & 37 & 0 & 4 & 0 & 41 \\ 19 & 79 & 0 & 2 & 0 & 81 \\ 69 & 18 & 2 & 9 & 2 & 31 \\ 96 & 3 & 0 & 0 & 0 & 4 \\ 32 & 21 & 6 & 20 & 21 & 68 \\ 35 & 19 & 24 & 15 & 6 & 65 \\ 57 & 20 & 7 & 12 & 4 & 43 \\ 47 & 21 & 25 & 4 & 2 & 53 \\ 39 & 28 & 3 & 28 & 3 & 61 \\ 39 & 16 & 29 & 16 & 0 & 61 \\ 58 & 16 & 9 & 17 & 0 & 42 \\ 74 & 14 & 2 & 10 & 0 & 26 \\ 91 & 3 & 1 & 2 & 3 & 9 \\ 29 & 20 & 39 & 12 & 0 & 71 \\ 22 & 26 & 9 & 43 & 0 & 78 \\ 29 & 15 & 45 & 11 & 0 & 71 \\ 46 & 23 & 30 & 1 & 0 & 54 \\ 69 & 22 & 4 & 5 & 0 & 31 \\ 29 & 27 & 43 & 1 & 0 & 71 \\ 53 & 9 & 33 & 5 & 0 & 47 \\ 68 & 9 & 17 & 6 & 0 & 32\end{array}$




\begin{tabular}{lllccccccc}
2016 & Triple A & ASW 5 & High Traffic Skid & 85 & 8 & 2 & 5 & 0 & 15 \\
2016 & Triple A & ASW 5 & Untrafficked & 41 & 13 & 43 & 2 & 0 & 59 \\
2016 & Triple A & ASW 6 & Feller buncher & 53 & 5 & 19 & 23 & 0 & 47 \\
2016 & Triple A & ASW 6 & Low Traffic Skid & 55 & 11 & 29 & 4 & 0 & 45 \\
2016 & Triple A & ASW 6 & High Traffic Skid & 82 & 9 & 3 & 6 & 0 & 18 \\
2016 & Triple A & ASW 6 & Untrafficked & 43 & 9 & 34 & 14 & 0 & 57 \\
2016 & Lower Femmons & FSW 9 & Feller buncher & 72 & 14 & 9 & 4 & 0 & 28 \\
2016 & Lower Femmons & FSW 9 & High Traffic Skid & 55 & 31 & 2 & 11 & 0 & 45 \\
2016 & Lower Femmons & FSW 9 & Untrafficked & 47 & 9 & 39 & 5 & 0 & 53 \\
2016 & Lower Femmons & FSW 10 & Mixed Traffic & 61 & 14 & 11 & 14 & 0 & 39 \\
2016 & Lower Femmons & FSW 10 & Feller buncher & 57 & 34 & 0 & 9 & 0 & 43 \\
2016 & Lower Femmons & FSW 10 & High Traffic Skid & 76 & 11 & 1 & 12 & 1 & 25 \\
2016 & Lower Femmons & FSW 10 & Untrafficked & 29 & 11 & 58 & 2 & 0 & 71 \\
\hline$\vec{F} 2016$ & Lower Femmons & FSW 10 & Subsoil & 89 & 4 & 0 & 7 & 0 & 11 \\
2016 & Lower Femmons & FSW 11 & Mixed Traffic & 48 & 9 & 3 & 40 & 0 & 52 \\
2016 & Lower Femmons & FSW 11 & Feller buncher & 48 & 25 & 21 & 7 & 0 & 52 \\
2016 & Lower Femmons & FSW 11 & Low Traffic Skid & 74 & 13 & 9 & 4 & 0 & 26 \\
2016 & Lower Femmons & FSW 11 & High Traffic Skid & 60 & 20 & 3 & 17 & 0 & 40 \\
2016 & Lower Femmons & FSW 11 & Untrafficked & 5 & 6 & 88 & 1 & 0 & 95 \\
2016 & Upper Femmons & FSW 13 & Low Traffic Skid & 81 & 8 & 1 & 7 & 4 & 19 \\
2016 & Upper Femmons & FSW 13 & High Traffic Skid & 87 & 3 & 0 & 4 & 7 & 14 \\
2016 & Upper Femmons & FSW 13 & Untrafficked & 82 & 1 & 7 & 0 & 9 & 18 \\
\hline
\end{tabular}


Appendix I: Swale surface and interception percent cover by year in the Rim Fire. Femmons is abbreviated by "FSW". "Status" refers to if the survey was pre or post salvage.

\begin{tabular}{|c|c|c|c|c|c|c|c|c|c|c|c|}
\hline Date & Status & Unit & Swale & Treatment & $\begin{array}{c}\text { Cover } \\
\text { Category }\end{array}$ & Soil & Litter & Veg & Wood & Rock & $\begin{array}{l}\text { Total } \\
\text { Cover }\end{array}$ \\
\hline 201408 & Pre & Triple A & ASW 1 & Logged & Interception & 49 & 23 & 17 & 3 & 8 & 51 \\
\hline 201408 & Pre & Triple A & ASW 2 & Control & Interception & 57 & 17 & 23 & 1 & 2 & 43 \\
\hline 201408 & Pre & Triple A & ASW 3 & Logged & Interception & 56 & 26 & 16 & 1 & 0 & 44 \\
\hline 201408 & Pre & Triple A & ASW 4 & Logged & Interception & 43 & 35 & 19 & 2 & 1 & 57 \\
\hline 201408 & Pre & Triple A & ASW 5 & Logged & Interception & 54 & 22 & 20 & 4 & 0 & 46 \\
\hline 201408 & Pre & Triple A & ASW 6 & Logged & Interception & 65 & 13 & 20 & 2 & 0 & 35 \\
\hline 201408 & Pre & Triple A & ASW 7 & Control & Interception & 79 & 12 & 7 & 2 & 1 & 21 \\
\hline 201408 & Pre & Lower FSW & FSW 8 & Control & Interception & 63 & 15 & 17 & 4 & 1 & 37 \\
\hline 201408 & Pre & Lower FSW & FSW 9 & Logged & Interception & 73 & 11 & 15 & 1 & 0 & 27 \\
\hline 201408 & Pre & Lower FSW & FSW 10 & Logged & Interception & 64 & 12 & 17 & 6 & 0 & 36 \\
\hline 201408 & Pre & Lower FSW & FSW 11 & Logged & Interception & 34 & 32 & 31 & 3 & 0 & 66 \\
\hline 201408 & Pre & Upper FSW & FSW 12 & Control & Interception & 70 & 17 & 2 & 4 & 7 & 30 \\
\hline 201408 & Pre & Upper FSW & FSW 13 & Logged & Interception & 80 & 9 & 5 & 2 & 4 & 20 \\
\hline 201408 & Pre & Upper FSW & FSW 14 & Control & Interception & 68 & 10 & 18 & 3 & 1 & 32 \\
\hline 201505 & Post & Triple A & ASW 1 & Logged & Interception & 24 & 26 & 28 & 17 & 5 & 76 \\
\hline 201505 & Post & Triple A & ASW 2 & Control & Interception & 28 & 8 & 63 & 1 & 0 & 72 \\
\hline 201505 & Post & Triple A & ASW 3 & Logged & Interception & 57 & 3 & 17 & 23 & 0 & 43 \\
\hline 201505 & Post & Triple A & ASW 4 & Logged & Interception & 22 & 31 & 31 & 17 & 0 & 78 \\
\hline 201505 & Post & Triple A & ASW 5 & Logged & Interception & 34 & 20 & 28 & 18 & 0 & 66 \\
\hline 201505 & Post & Triple A & ASW 6 & Logged & Interception & 35 & 11 & 42 & 12 & 0 & 65 \\
\hline 201505 & Post & Triple A & ASW 7 & Control & Interception & 67 & 12 & 16 & 5 & 1 & 33 \\
\hline 201505 & Pre & Lower FSW & FSW 8 & Control & Interception & 58 & 3 & 35 & 3 & 0 & 42 \\
\hline 201505 & Pre & Lower FSW & FSW 9 & Logged & Interception & 57 & 7 & 33 & 3 & 0 & 43 \\
\hline
\end{tabular}




\begin{tabular}{|c|c|c|c|c|c|c|c|c|c|c|c|}
\hline 201505 & Pre & Lower FSW & FSW 10 & Logged & Interception & 49 & 7 & 40 & 4 & 0 & 51 \\
\hline 201505 & Pre & Lower FSW & FSW 11 & Logged & Interception & NA & NA & NA & NA & NA & NA \\
\hline 201505 & Pre & Upper FSW & FSW 12 & Control & Interception & 82 & 12 & 3 & 1 & 0 & 8 \\
\hline 201505 & Pre & Upper FSW & FSW 13 & Logged & Interception & 70 & 13 & 15 & 2 & 1 & 30 \\
\hline 201505 & Pre & Upper FSW & FSW 14 & Control & Interception & 45 & 38 & 11 & 5 & 1 & 55 \\
\hline 201507 & Post & Lower FSW & FSW 8 & Control & Interception & 39 & 13 & 46 & 2 & 0 & 61 \\
\hline 201507 & Post & Lower FSW & FSW 9 & Logged & Interception & 48 & 12 & 31 & 9 & 0 & 52 \\
\hline 201507 & Post & Lower FSW & FSW 10 & Logged & Interception & 51 & 14 & 18 & 16 & 0 & 49 \\
\hline 201507 & Post & Lower FSW & FSW 11 & Logged & Interception & 29 & 14 & 44 & 13 & 0 & 11 \\
\hline 201605 & Post & Triple A & ASW 1 & Logged & Interception & 20 & 13 & 46 & 16 & 5 & \\
\hline 201605 & Post & Triple A & ASW 2 & Control & Interception & 7 & 8 & 72 & 12 & 1 & \\
\hline 201605 & Post & Triple A & ASW 3 & Logged & Interception & 22 & 6 & 62 & 10 & 0 & \\
\hline 201605 & Post & Triple A & ASW 4 & Logged & Interception & 11 & 15 & 61 & 13 & 0 & \\
\hline 201605 & Post & Triple A & ASW 5 & Logged & Interception & 10 & 15 & 63 & 12 & 0 & \\
\hline 201605 & Post & Triple A & ASW 6 & Logged & Interception & 22 & 5 & 64 & 9 & 0 & 0 \\
\hline 201605 & Post & Triple A & ASW 7 & Control & Interception & 47 & 11 & 27 & 14 & 2 & 3 \\
\hline 201605 & Post & Lower FSW & FSW 8 & Control & Interception & 26 & 9 & 60 & 5 & 0 & \\
\hline 201605 & Post & Lower FSW & FSW 9 & Logged & Interception & 30 & 10 & 48 & 12 & 0 & 70 \\
\hline 201605 & Post & Lower FSW & FSW 10 & Logged & Interception & 31 & 15 & 33 & 21 & 1 & \\
\hline 201605 & Post & Lower FSW & FSW 11 & Logged & Interception & 12 & 6 & 68 & 14 & 0 & \\
\hline 201605 & Post & Upper FSW & FSW 12 & Control & Interception & 68 & 1 & 14 & 5 & 12 & \\
\hline 201605 & Post & Upper FSW & FSW 13 & Logged & Interception & 49 & 4 & 28 & 12 & 8 & \\
\hline 201605 & Post & Upper FSW & FSW 14 & Control & Interception & 34 & 25 & 26 & 5 & 10 & \\
\hline 201408 & Pre & Triple A & ASW 1 & Logged & Surface & 61 & 27 & 0 & 3 & 8 & \\
\hline 201408 & Pre & Triple A & ASW 2 & Control & Surface & 77 & 19 & 1 & 1 & 2 & . \\
\hline 201408 & Pre & Triple A & ASW 3 & Logged & Surface & 66 & 31 & 1 & 1 & 0 & \\
\hline
\end{tabular}




\begin{tabular}{|c|c|c|c|c|c|c|c|c|c|c|c|}
\hline 201408 & Pre & Triple A & ASW 4 & Logged & Surface & 54 & 42 & 1 & 2 & 1 & 46 \\
\hline 201408 & Pre & Triple A & ASW 5 & Logged & Surface & 68 & 29 & 1 & 1 & 0 & 32 \\
\hline 201408 & Pre & Triple A & ASW 6 & Logged & Surface & 80 & 17 & 1 & 2 & 0 & 20 \\
\hline 201408 & Pre & Triple A & ASW 7 & Control & Surface & 85 & 12 & 1 & 1 & 1 & 15 \\
\hline 201408 & Pre & Lower FSW & FSW 8 & Control & Surface & 78 & 17 & 2 & 2 & 1 & 22 \\
\hline 201408 & Pre & Lower FSW & FSW 9 & Logged & Surface & 85 & 12 & 1 & 2 & 0 & 15 \\
\hline 201408 & Pre & Lower FSW & FSW 10 & Logged & Surface & 83 & 14 & 0 & 3 & 0 & 17 \\
\hline 201408 & Pre & Lower FSW & FSW 11 & Logged & Surface & 56 & 41 & 2 & 2 & 0 & 44 \\
\hline 201408 & Pre & Upper FSW & FSW 12 & Control & Surface & 73 & 17 & 1 & 1 & 7 & 27 \\
\hline 201408 & Pre & Upper FSW & FSW 13 & Logged & Surface & 84 & 10 & 1 & 1 & 4 & 16 \\
\hline 201408 & Pre & Upper FSW & FSW 14 & Control & Surface & 84 & 12 & 2 & 1 & 1 & 16 \\
\hline 201505 & Post & Triple A & ASW 1 & Logged & Surface & 39 & 34 & 5 & 17 & 5 & \\
\hline 201505 & Post & Triple A & ASW 2 & Control & Surface & 70 & 12 & 17 & 1 & 0 & 30 \\
\hline 201505 & Post & Triple A & ASW 3 & Logged & Surface & 65 & 4 & 8 & 23 & 0 & 35 \\
\hline 201505 & Post & Triple A & ASW 4 & Logged & Surface & 42 & 42 & 0 & 17 & 0 & 58 \\
\hline 201505 & Post & Triple A & ASW 5 & Logged & Surface & 45 & 36 & 0 & 18 & 0 & 55 \\
\hline 201505 & Post & Triple A & ASW 6 & Logged & Surface & 76 & 12 & 0 & 12 & 0 & 24 \\
\hline 201505 & Post & Triple A & ASW 7 & Control & Surface & 83 & 12 & 0 & 5 & 1 & 17 \\
\hline 201505 & Pre & Lower FSW & FSW 8 & Control & Surface & 94 & 3 & 0 & 3 & 0 & 6 \\
\hline 201505 & Pre & Lower FSW & FSW 9 & Logged & Surface & 90 & 7 & 0 & 3 & 0 & 10 \\
\hline 201505 & Pre & Lower FSW & FSW 10 & Logged & Surface & 79 & 13 & 4 & 3 & 0 & 21 \\
\hline 201505 & Pre & Lower FSW & FSW 11 & Logged & Surface & NA & NA & NA & NA & NA & NA \\
\hline 201505 & Pre & Upper FSW & FSW 12 & Control & Surface & 85 & 14 & 0 & 1 & 0 & 15 \\
\hline 201505 & Pre & Upper FSW & FSW 13 & Logged & Surface & 83 & 14 & 0 & 2 & 1 & 17 \\
\hline 201505 & Pre & Upper FSW & FSW 14 & Control & Surface & 51 & 43 & 0 & 5 & 1 & 49 \\
\hline 201507 & Post & Lower FSW & FSW 8 & Control & Surface & 65 & 24 & 7 & 3 & 0 & \\
\hline
\end{tabular}




\begin{tabular}{|c|c|c|c|c|c|c|c|c|c|c|c|}
\hline 201507 & Post & Lower FSW & FSW 9 & Logged & Surface & 65 & 19 & 7 & 9 & 0 & 35 \\
\hline 201507 & Post & Lower FSW & FSW 10 & Logged & Surface & 63 & 18 & 5 & 14 & 0 & 37 \\
\hline 201507 & Post & Lower FSW & FSW 11 & Logged & Surface & 37 & 39 & 10 & 14 & 0 & 63 \\
\hline 201605 & Post & Triple A & ASW 1 & Logged & Surface & 43 & 24 & 12 & 15 & 7 & 57 \\
\hline 201605 & Post & Triple A & ASW 2 & Control & Surface & 31 & 31 & 28 & 8 & 1 & 69 \\
\hline 201605 & Post & Triple A & ASW 3 & Logged & Surface & 45 & 20 & 25 & 10 & 0 & 55 \\
\hline 201605 & Post & Triple A & ASW 4 & Logged & Surface & 38 & 29 & 20 & 13 & 0 & 62 \\
\hline 201605 & Post & Triple A & ASW 5 & Logged & Surface & 47 & 21 & 19 & 13 & 0 & 53 \\
\hline 201605 & Post & Triple A & ASW 6 & Logged & Surface & 50 & 10 & 32 & 8 & 0 & 50 \\
\hline 201605 & Post & Triple A & ASW 7 & Control & Surface & 75 & 10 & 4 & 9 & 2 & 25 \\
\hline 201605 & Post & Lower FSW & FSW 8 & Control & Surface & 53 & 15 & 26 & 6 & 0 & 47 \\
\hline 201605 & Post & Lower FSW & FSW 9 & Logged & Surface & 57 & 12 & 17 & 14 & 0 & 43 \\
\hline 201605 & Post & Lower FSW & FSW 10 & Logged & Surface & 47 & 17 & 16 & 19 & 1 & 53 \\
\hline 201605 & Post & Lower FSW & FSW 11 & Logged & Surface & 31 & 9 & 46 & 13 & 0 & 69 \\
\hline 201605 & Post & Upper FSW & FSW 12 & Control & Surface & 80 & 1 & 4 & 2 & 13 & 20 \\
\hline 201605 & Post & Upper FSW & FSW 13 & Logged & Surface & 70 & 4 & 7 & 10 & 9 & 30 \\
\hline 201605 & Post & Upper FSW & FSW 14 & Control & Surface & 53 & 25 & 8 & 3 & 10 & 47 \\
\hline
\end{tabular}


Appendix J: Precipitation data for Rim Fire swale rain gages by event. Femmons is abbreviated by "FSW".

\begin{tabular}{|c|c|c|c|c|c|c|c|c|}
\hline Unit & Swale & Begin & End & $\begin{array}{l}\text { Duration } \\
\text { (min) }\end{array}$ & $\begin{array}{l}\text { Depth } \\
(\mathrm{mm})\end{array}$ & $\begin{array}{c}\mathrm{I}_{10} \\
\left(\mathrm{~mm} \mathrm{hr}^{-1}\right)\end{array}$ & $\begin{array}{c}\mathrm{I}_{30} \\
\left(\mathrm{~mm} \mathrm{hr}^{-1}\right)\end{array}$ & $\begin{array}{c}\mathrm{I}_{60} \\
\left(\mathrm{~mm} \mathrm{hr}^{-1}\right)\end{array}$ \\
\hline Triple A & ASW 1 & $1 / 27 / 15$ & $1 / 27 / 2015$ & 234 & 3.302 & 17 & 16 & 15 \\
\hline Triple A & ASW 1 & $2 / 6 / 15$ & $2 / 7 / 2015$ & 1740 & 49.784 & 15 & 12 & 11 \\
\hline Triple A & ASW 1 & $2 / 8 / 15$ & $2 / 9 / 2015$ & 1269 & 44.704 & 9 & 6 & 5 \\
\hline Triple A & ASW 1 & $2 / 22 / 15$ & $2 / 22 / 2015$ & 144 & 2.032 & 20 & 13 & 11 \\
\hline Triple A & ASW 1 & $2 / 27 / 15$ & $2 / 28 / 2015$ & 1236 & 6.604 & 8 & 5 & 3 \\
\hline Triple A & ASW 1 & $3 / 1 / 15$ & $3 / 1 / 2015$ & 19 & 0.508 & 12 & 5 & 5 \\
\hline Triple A & ASW 1 & $3 / 2 / 15$ & $3 / 2 / 2015$ & 243 & 5.334 & 12 & 10 & 8 \\
\hline Triple A & ASW 1 & $3 / 11 / 15$ & $3 / 11 / 2015$ & 139 & 2.794 & 12 & 6 & 4 \\
\hline Triple A & ASW 1 & $3 / 22 / 15$ & $3 / 22 / 2015$ & 60 & 4.318 & 40 & 23 & 12 \\
\hline Triple A & ASW 1 & $4 / 5 / 15$ & $4 / 5 / 2015$ & 159 & 5.842 & 23 & 18 & 10 \\
\hline Triple A & ASW 1 & $4 / 6 / 15$ & $4 / 6 / 2015$ & 105 & 9.398 & 2 & 1 & 1 \\
\hline Triple A & ASW 1 & $4 / 7 / 15$ & $4 / 7 / 2015$ & 212 & 6.096 & 23 & 14 & 10 \\
\hline Triple A & ASW 1 & $4 / 8 / 15$ & $4 / 8 / 2015$ & 117 & 17.272 & 26 & 13 & 7 \\
\hline Triple A & ASW 1 & $4 / 19 / 15$ & $4 / 19 / 2015$ & 1 & 0.254 & 26 & 14 & 7 \\
\hline Triple A & ASW 1 & $4 / 23 / 15$ & $4 / 23 / 2015$ & 193 & 3.556 & 11 & 8 & 7 \\
\hline Triple A & ASW 1 & $4 / 25 / 15$ & $4 / 25 / 2015$ & 1046 & 22.098 & 8 & 7 & 6 \\
\hline Triple A & ASW 1 & $4 / 26 / 15$ & $4 / 26 / 2015$ & 1 & 0.254 & 6 & 6 & 5 \\
\hline Triple A & ASW 1 & $5 / 7 / 15$ & $5 / 8 / 2015$ & 1591 & 26.162 & 9 & 7 & 6 \\
\hline Triple A & ASW 1 & $5 / 14 / 15$ & $5 / 14 / 2015$ & 207 & 1.27 & 11 & 8 & 8 \\
\hline Triple A & ASW 1 & $5 / 15 / 15$ & $5 / 15 / 2015$ & 62 & 0.508 & 11 & 8 & 7 \\
\hline Triple A & ASW 1 & $5 / 15 / 15$ & $5 / 15 / 2015$ & 308 & 5.334 & 15 & 11 & 8 \\
\hline Triple A & ASW 1 & $5 / 16 / 15$ & $5 / 16 / 2015$ & 1 & 0.254 & 15 & 13 & 12 \\
\hline
\end{tabular}




$\begin{array}{ccccccccc}\text { Triple A } & \text { ASW 1 } & 5 / 17 / 15 & 5 / 17 / 2015 & 48 & 1.27 & 8 & 7 & 6 \\ \text { Triple A } & \text { ASW 1 } & 5 / 18 / 15 & 5 / 18 / 2015 & 251 & 0.508 & 12 & 7 & 5 \\ \text { Triple A } & \text { ASW 1 } & 5 / 18 / 15 & 5 / 18 / 2015 & 1 & 0.254 & 6 & 4 & 3 \\ \text { Triple A } & \text { ASW 1 } & 5 / 19 / 15 & 5 / 19 / 2015 & 1 & 0.254 & 29 & 19 & 13 \\ \text { Triple A } & \text { ASW 1 } & 5 / 21 / 15 & 5 / 21 / 2015 & 33 & 1.27 & 14 & 12 & 9 \\ \text { Triple A } & \text { ASW 1 } & 5 / 22 / 15 & 5 / 22 / 2015 & 85 & 1.016 & 21 & 14 & 11 \\ \text { Triple A } & \text { ASW 1 } & 5 / 23 / 15 & 5 / 24 / 2015 & 277 & 12.446 & 9 & 6 & 5 \\ \text { Triple A } & \text { ASW 1 } & 6 / 5 / 15 & 6 / 5 / 2015 & 57 & 1.524 & 9 & 7 & 6 \\ \text { Triple A } & \text { ASW 1 } & 7 / 2 / 15 & 7 / 2 / 2015 & 50 & 1.524 & 12 & 9 & 9 \\ \text { Triple A } & \text { ASW 1 } & 7 / 3 / 15 & 7 / 3 / 2015 & 27 & 2.794 & 6 & 6 & 5 \\ \text { Triple A } & \text { ASW 1 } & 7 / 9 / 15 & 7 / 9 / 2015 & 214 & 11.938 & 12 & 10 & 8 \\ \text { Triple A } & \text { ASW 1 } & 7 / 10 / 15 & 7 / 10 / 2015 & 1 & 0.254 & 11 & 4 & 2 \\ \text { Triple A } & \text { ASW 1 } & 7 / 19 / 15 & 7 / 19 / 2015 & 95 & 3.302 & 8 & 6 & 6 \\ \text { Triple A } & \text { ASW 1 } & 7 / 20 / 15 & 7 / 21 / 2015 & 1243 & 7.366 & 11 & 9 & 7 \\ \text { Triple A } & \text { ASW 1 } & 7 / 22 / 15 & 7 / 22 / 2015 & 1 & 0.254 & 15 & 9 & 9 \\ \text { Triple A } & \text { ASW 1 } & 7 / 31 / 15 & 7 / 31 / 2015 & 12 & 1.016 & 21 & 12 & 9 \\ \text { Triple A } & \text { ASW 1 } & 9 / 15 / 15 & 9 / 15 / 2015 & 30 & 0.762 & 3 & 2 & 2 \\ \text { Triple A } & \text { ASW 1 } & 10 / 1 / 15 & 10 / 1 / 2015 & 228 & 12.192 & 15 & 11 & 9 \\ \text { Triple A } & \text { ASW 1 } & 10 / 15 / 15 & 10 / 15 / 2015 & 26 & 1.016 & 5 & 4 & 3 \\ \text { Triple A } & \text { ASW 1 } & 10 / 16 / 15 & 10 / 16 / 2015 & 76 & 3.048 & 17 & 7 & 6 \\ \text { Triple A } & \text { ASW 1 } & 10 / 17 / 15 & 10 / 17 / 2015 & 247 & 9.906 & 6 & 5 & 5 \\ \text { Triple A } & \text { ASW 1 } & 10 / 18 / 15 & 10 / 18 / 2015 & 25 & 1.016 & 5 & 3 & 3 \\ \text { Triple A } & \text { ASW 1 } & 10 / 28 / 15 & 10 / 28 / 2015 & 206 & 7.366 & 3 & 2 & 2 \\ \text { Triple A } & \text { ASW 1 } & 10 / 28 / 15 & 10 / 28 / 2015 & 199 & 8.636 & 6 & 5 & 4 \\ \text { Triple A } & \text { ASW 1 } & 10 / 29 / 15 & 10 / 29 / 2015 & 1 & 0.254 & 11 & 8 & 7 \\ \text { Triple A } & \text { ASW 1 } & 11 / 2 / 15 & 11 / 3 / 2015 & 1573 & 54.356 & 11 & 7 & 5 \\ & & & & & & & & \end{array}$




$\begin{array}{ccccccccc}\text { Triple A } & \text { ASW 1 } & 11 / 4 / 15 & 11 / 4 / 2015 & 1 & 0.254 & 5 & 3 & 2 \\ \text { Triple A } & \text { ASW 1 } & 11 / 8 / 15 & 11 / 9 / 2015 & 384 & 11.938 & 12 & 9 & 9 \\ \text { Triple A } & \text { ASW 1 } & 11 / 9 / 15 & 11 / 9 / 2015 & 411 & 5.334 & 9 & 7 & 6 \\ \text { Triple A } & \text { ASW 1 } & 11 / 10 / 15 & 11 / 10 / 2015 & 77 & 2.54 & 8 & 6 & 4 \\ \text { Triple A } & \text { ASW 1 } & 11 / 15 / 15 & 11 / 15 / 2015 & 363 & 8.128 & 11 & 5 & 2 \\ \text { Triple A } & \text { ASW 1 } & 11 / 16 / 15 & 11 / 16 / 2015 & 395 & 10.922 & 9 & 7 & 6 \\ \text { Triple A } & \text { ASW 1 } & 11 / 17 / 15 & 11 / 17 / 2015 & 196 & 3.048 & 12 & 9 & 7 \\ \text { Triple A } & \text { ASW 1 } & 11 / 24 / 15 & 11 / 24 / 2015 & 133 & 7.874 & 15 & 10 & 9 \\ \text { Triple A } & \text { ASW 1 } & 11 / 25 / 15 & 11 / 25 / 2015 & 313 & 2.032 & 17 & 11 & 9 \\ \text { Triple A } & \text { ASW 1 } & 11 / 26 / 15 & 11 / 26 / 2015 & 461 & 6.35 & 27 & 14 & 12 \\ \text { Triple A } & \text { ASW 1 } & 11 / 27 / 15 & 11 / 27 / 2015 & 82 & 0.762 & 9 & 9 & 7 \\ \text { Triple A } & \text { ASW 1 } & 12 / 3 / 15 & 12 / 3 / 2015 & 314 & 5.334 & 6 & 5 & 5 \\ \text { Triple A } & \text { ASW 1 } & 12 / 10 / 15 & 12 / 10 / 2015 & 484 & 15.748 & 6 & 6 & 5 \\ \text { Triple A } & \text { ASW 1 } & 12 / 11 / 15 & 12 / 11 / 2015 & 310 & 5.588 & 15 & 7 & 5 \\ \text { Triple A } & \text { ASW 1 } & 12 / 12 / 15 & 12 / 13 / 2015 & 1812 & 22.86 & 11 & 7 & 5 \\ \text { Triple A } & \text { ASW 1 } & 12 / 14 / 15 & 12 / 14 / 2015 & 398 & 8.128 & 8 & 6 & 5 \\ \text { Triple A } & \text { ASW 1 } & 12 / 15 / 15 & 12 / 15 / 2015 & 324 & 2.286 & 11 & 9 & 6 \\ \text { Triple A } & \text { ASW 1 } & 12 / 16 / 15 & 12 / 16 / 2015 & 305 & 1.778 & 11 & 10 & 9 \\ \text { Triple A } & \text { ASW 1 } & 12 / 17 / 15 & 12 / 17 / 2015 & 109 & 0.762 & 9 & 7 & 5 \\ \text { Triple A } & \text { ASW 1 } & 12 / 19 / 15 & 12 / 19 / 2015 & 650 & 6.858 & 8 & 7 & 6 \\ \text { Triple A } & \text { ASW 1 } & 12 / 20 / 15 & 12 / 22 / 2015 & 2994 & 78.74 & 12 & 9 & 7 \\ \text { Triple A } & \text { ASW 1 } & 12 / 23 / 15 & 12 / 23 / 2015 & 438 & 1.016 & 17 & 10 & 9 \\ \text { Triple A } & \text { ASW 1 } & 12 / 25 / 15 & 12 / 25 / 2015 & 230 & 4.826 & 18 & 13 & 10 \\ \text { Triple A } & \text { ASW 1 } & 12 / 26 / 15 & 12 / 26 / 2015 & 285 & 2.54 & 27 & 14 & 11 \\ \text { Triple A } & \text { ASW 1 } & 12 / 27 / 15 & 12 / 27 / 2015 & 244 & 1.778 & 20 & 11 & 8 \\ \text { Triple A } & \text { ASW 1 } & 12 / 28 / 15 & 12 / 28 / 2015 & 8 & 0.508 & 6 & 5 & 5\end{array}$




\begin{tabular}{|c|c|c|c|c|c|c|c|}
\hline Triple A & ASW 1 & $12 / 29 / 15$ & $12 / 29 / 2015$ & 106 & 0.508 & 8 & 6 \\
\hline Triple A & ASW 1 & $12 / 30 / 15$ & $12 / 30 / 2015$ & 1 & 0.254 & 12 & 7 \\
\hline Triple A & ASW 1 & 1/4/16 & $1 / 4 / 2016$ & 1 & 0.254 & 9 & 7 \\
\hline Triple A & ASW 1 & $1 / 5 / 16$ & $1 / 5 / 2016$ & 941 & 26.416 & 8 & 6 \\
\hline Triple A & ASW 1 & $1 / 6 / 16$ & $1 / 6 / 2016$ & 1 & 0.254 & 15 & 11 \\
\hline Triple A & ASW 1 & $1 / 8 / 16$ & $1 / 8 / 2016$ & 397 & 11.43 & 3 & 2 \\
\hline Triple A & ASW 1 & $1 / 9 / 16$ & $1 / 10 / 2016$ & 1627 & 12.954 & 6 & 3 \\
\hline Triple A & ASW 1 & $1 / 13 / 16$ & $1 / 13 / 2016$ & 65 & 1.524 & 5 & 2 \\
\hline Triple A & ASW 1 & $1 / 14 / 16$ & $1 / 15 / 2016$ & 681 & 12.192 & 2 & 1 \\
\hline Triple A & ASW 1 & $1 / 15 / 16$ & $1 / 15 / 2016$ & 1 & 0.254 & 8 & 5 \\
\hline Triple A & ASW 1 & $1 / 16 / 16$ & $1 / 16 / 2016$ & 357 & 5.588 & 3 & 2 \\
\hline Triple A & ASW 1 & $1 / 16 / 16$ & $1 / 16 / 2016$ & 21 & 2.794 & 17 & 7 \\
\hline Triple A & ASW 1 & $1 / 16 / 16$ & $1 / 16 / 2016$ & 1 & 0.254 & 6 & 5 \\
\hline Triple A & ASW 1 & $1 / 17 / 16$ & $1 / 18 / 2016$ & 677 & 22.86 & 14 & 11 \\
\hline Triple A & ASW 1 & $1 / 19 / 16$ & $1 / 19 / 2016$ & 486 & 25.908 & 2 & 1 \\
\hline Triple A & ASW 1 & $1 / 22 / 16$ & $1 / 23 / 2016$ & 1262 & 47.752 & 2 & 1 \\
\hline Triple A & ASW 1 & $1 / 23 / 16$ & $1 / 23 / 2016$ & 83 & 0.508 & 2 & 1 \\
\hline Triple A & ASW 1 & $1 / 29 / 16$ & $1 / 30 / 2016$ & 804 & 25.654 & 2 & 1 \\
\hline Triple A & ASW 1 & $1 / 31 / 16$ & $1 / 31 / 2016$ & 1 & 0.254 & 2 & 1 \\
\hline Triple A & ASW 1 & $2 / 2 / 16$ & $2 / 2 / 2016$ & 350 & 6.096 & 5 & 2 \\
\hline Triple A & ASW 1 & $2 / 3 / 16$ & $2 / 3 / 2016$ & 350 & 9.398 & 2 & 1 \\
\hline Triple A & ASW 1 & $2 / 4 / 16$ & $2 / 4 / 2016$ & 307 & 5.334 & 2 & 1 \\
\hline Triple A & ASW 1 & $2 / 17 / 16$ & $2 / 18 / 2016$ & 178 & 8.89 & 2 & 1 \\
\hline Triple A & ASW 1 & $2 / 18 / 16$ & $2 / 18 / 2016$ & 230 & 14.732 & 3 & 2 \\
\hline Triple A & ASW 1 & $2 / 19 / 16$ & $2 / 19 / 2016$ & 1 & 0.254 & 3 & 2 \\
\hline Triple A & ASW 1 & $3 / 3 / 16$ & $3 / 3 / 2016$ & 48 & 5.334 & 5 & 3 \\
\hline
\end{tabular}




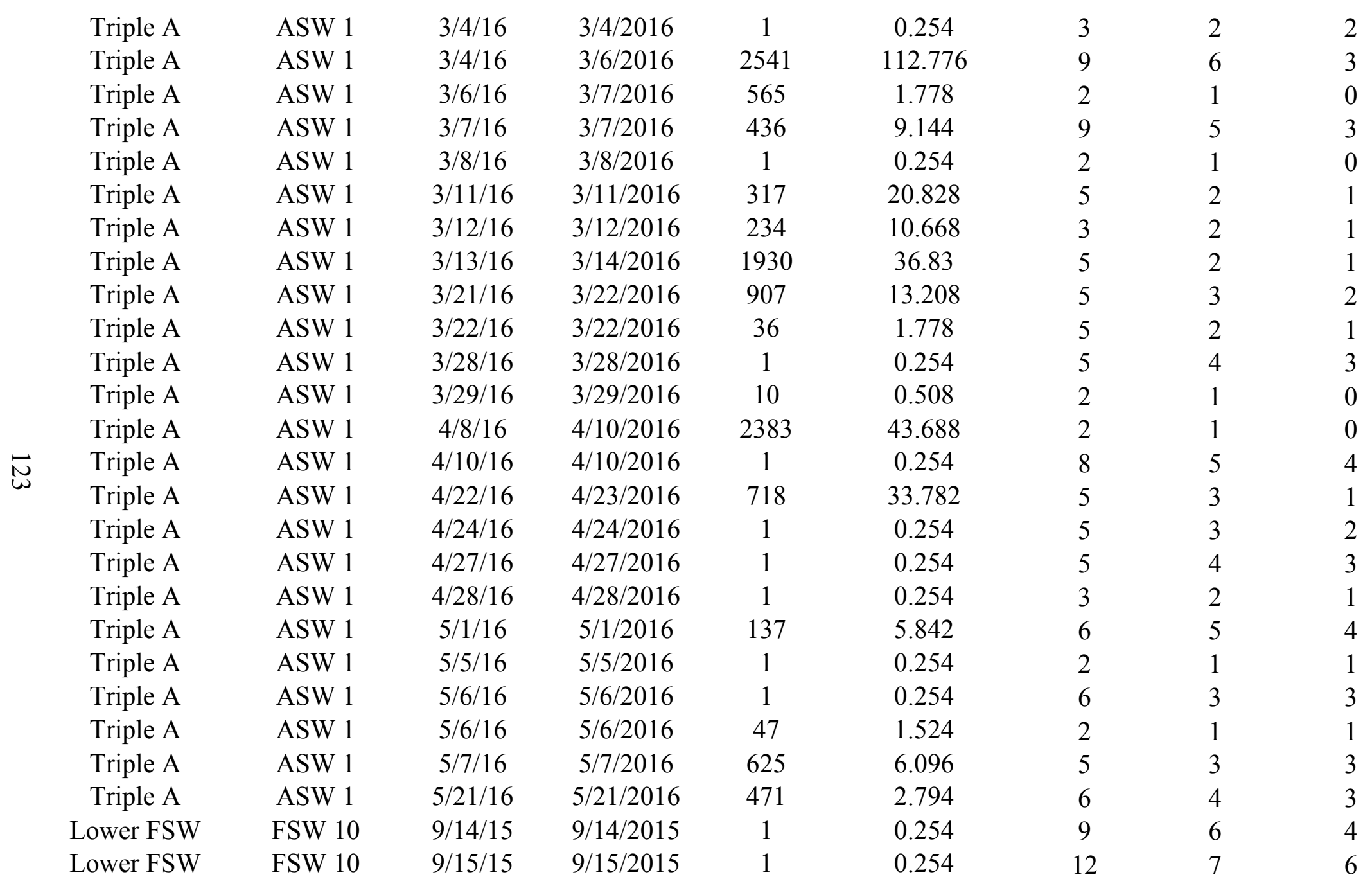




$\begin{array}{ccccccccc}\text { Lower FSW } & \text { FSW 10 } & 10 / 1 / 15 & 10 / 1 / 2015 & 294 & 22.098 & 9 & 6 & 4 \\ \text { Lower FSW } & \text { FSW 10 } & 10 / 17 / 15 & 10 / 17 / 2015 & 261 & 2.54 & 3 & 1 & 1 \\ \text { Lower FSW } & \text { FSW 10 } & 10 / 28 / 15 & 10 / 28 / 2015 & 409 & 9.906 & 2 & 1 & 1 \\ \text { Lower FSW } & \text { FSW 10 } & 10 / 28 / 15 & 10 / 28 / 2015 & 38 & 3.81 & 2 & 1 & 1 \\ \text { Lower FSW } & \text { FSW 10 } & 11 / 2 / 15 & 11 / 3 / 2015 & 1437 & 58.674 & 3 & 2 & 2 \\ \text { Lower FSW } & \text { FSW 10 } & 11 / 3 / 15 & 11 / 3 / 2015 & 11 & 0.508 & 2 & 1 & 0 \\ \text { Lower FSW } & \text { FSW 10 } & 11 / 8 / 15 & 11 / 9 / 2015 & 459 & 20.828 & 6 & 4 & 3 \\ \text { Lower FSW } & \text { FSW 10 } & 11 / 9 / 15 & 11 / 9 / 2015 & 462 & 5.588 & 2 & 1 & 1 \\ \text { Lower FSW } & \text { FSW 10 } & 11 / 10 / 15 & 11 / 10 / 2015 & 225 & 9.906 & 2 & 1 & 1 \\ \text { Lower FSW } & \text { FSW 10 } & 11 / 15 / 15 & 11 / 15 / 2015 & 539 & 21.844 & 3 & 1 & 1 \\ \text { Lower FSW } & \text { FSW 10 } & 11 / 16 / 15 & 11 / 16 / 2015 & 372 & 8.382 & 2 & 1 & 0 \\ \text { Lower FSW } & \text { FSW 10 } & 11 / 17 / 15 & 11 / 17 / 2015 & 59 & 0.508 & 2 & 1 & 0 \\ \text { Lower FSW } & \text { FSW 10 } & 11 / 24 / 15 & 11 / 24 / 2015 & 264 & 10.414 & 2 & 1 & 0 \\ \text { Lower FSW } & \text { FSW 10 } & 11 / 25 / 15 & 11 / 25 / 2015 & 273 & 3.048 & 2 & 1 & 0 \\ \text { Lower FSW } & \text { FSW 10 } & 11 / 26 / 15 & 11 / 26 / 2015 & 225 & 2.794 & 17 & 8 & 6 \\ \text { Lower FSW } & \text { FSW 10 } & 12 / 3 / 15 & 12 / 3 / 2015 & 100 & 4.318 & 3 & 2 & 2 \\ \text { Lower FSW } & \text { FSW 10 } & 12 / 4 / 15 & 12 / 4 / 2015 & 1 & 0.254 & 3 & 2 & 1 \\ \text { Lower FSW } & \text { FSW 10 } & 12 / 10 / 15 & 12 / 10 / 2015 & 924 & 26.924 & 6 & 6 & 4 \\ \text { Lower FSW } & \text { FSW 10 } & 12 / 11 / 15 & 12 / 11 / 2015 & 672 & 18.034 & 2 & 1 & 0 \\ \text { Lower FSW } & \text { FSW 10 } & 12 / 12 / 15 & 12 / 13 / 2015 & 1885 & 23.114 & 6 & 4 & 2 \\ \text { Lower FSW } & \text { FSW 10 } & 12 / 14 / 15 & 12 / 14 / 2015 & 349 & 7.62 & 12 & 6 & 3 \\ \text { Lower FSW } & \text { FSW 10 } & 12 / 15 / 15 & 12 / 15 / 2015 & 357 & 2.54 & 2 & 1 & 0 \\ \text { Lower FSW } & \text { FSW 10 } & 12 / 16 / 15 & 12 / 16 / 2015 & 226 & 1.524 & 6 & 5 & 5 \\ \text { Lower FSW } & \text { FSW 10 } & 12 / 17 / 15 & 12 / 17 / 2015 & 1 & 0.254 & 2 & 1 & 0 \\ \text { Lower FSW } & \text { FSW 10 } & 12 / 19 / 15 & 12 / 19 / 2015 & 858 & 17.018 & 11 & 7 & 6 \\ \text { Lower FSW } & \text { FSW 10 } & 12 / 20 / 15 & 12 / 20 / 2015 & 1 & 0.254 & 2 & 1 & 0\end{array}$




$\begin{array}{ccccccccc}\text { Lower FSW } & \text { FSW 10 } & 12 / 20 / 15 & 12 / 22 / 2015 & 2543 & 188.722 & 5 & 3 & 2 \\ \text { Lower FSW } & \text { FSW 10 } & 12 / 23 / 15 & 12 / 23 / 2015 & 361 & 0.762 & 3 & 3 & 3 \\ \text { Lower FSW } & \text { FSW 10 } & 12 / 23 / 15 & 12 / 23 / 2015 & 1 & 0.254 & 3 & 2 & 2 \\ \text { Lower FSW } & \text { FSW 10 } & 12 / 26 / 15 & 12 / 26 / 2015 & 1 & 0.254 & 14 & 9 & 6 \\ \text { Lower FSW } & \text { FSW 10 } & 12 / 27 / 15 & 12 / 27 / 2015 & 364 & 6.096 & 2 & 1 & 0 \\ \text { Lower FSW } & \text { FSW 10 } & 12 / 28 / 15 & 12 / 28 / 2015 & 238 & 2.032 & 11 & 9 & 5 \\ \text { Lower FSW } & \text { FSW 10 } & 12 / 29 / 15 & 12 / 29 / 2015 & 289 & 2.794 & 2 & 1 & 0 \\ \text { Lower FSW } & \text { FSW 10 } & 12 / 30 / 15 & 12 / 30 / 2015 & 270 & 2.032 & 2 & 1 & 1 \\ \text { Lower FSW } & \text { FSW 10 } & 12 / 31 / 15 & 12 / 31 / 2015 & 193 & 0.762 & 8 & 6 & 5 \\ \text { Lower FSW } & \text { FSW 10 } & 1 / 4 / 16 & 1 / 4 / 2016 & 33 & 0.508 & 2 & 1 & 0 \\ \text { Lower FSW } & \text { FSW 10 } & 1 / 5 / 16 & 1 / 5 / 2016 & 835 & 27.686 & 6 & 3 & 3 \\ \text { Lower FSW } & \text { FSW 10 } & 1 / 6 / 16 & 1 / 7 / 2016 & 1869 & 33.274 & 5 & 3 & 2 \\ \text { Lower FSW } & \text { FSW 10 } & 1 / 8 / 16 & 1 / 8 / 2016 & 394 & 10.668 & 2 & 1 & 0 \\ \text { Lower FSW } & \text { FSW 10 } & 1 / 9 / 16 & 1 / 10 / 2016 & 1223 & 9.144 & 3 & 1 & 1 \\ \text { Lower FSW } & \text { FSW 10 } & 1 / 13 / 16 & 1 / 13 / 2016 & 286 & 4.318 & 15 & 10 & 6 \\ \text { Lower FSW } & \text { FSW 10 } & 1 / 14 / 16 & 1 / 15 / 2016 & 892 & 23.622 & 2 & 1 & 0 \\ \text { Lower FSW } & \text { FSW 10 } & 1 / 16 / 16 & 1 / 16 / 2016 & 1034 & 9.144 & 2 & 1 & 0 \\ \text { Lower FSW } & \text { FSW 10 } & 1 / 18 / 16 & 1 / 18 / 2016 & 527 & 26.162 & 2 & 1 & 0 \\ \text { Lower FSW } & \text { FSW 10 } & 1 / 19 / 16 & 1 / 19 / 2016 & 632 & 26.162 & 2 & 1 & 0 \\ \text { Lower FSW } & \text { FSW 10 } & 1 / 20 / 16 & 1 / 20 / 2016 & 1 & 0.254 & 12 & 8 & 5 \\ \text { Lower FSW } & \text { FSW 10 } & 1 / 22 / 16 & 1 / 23 / 2016 & 1223 & 38.862 & 2 & 1 & 0 \\ \text { Lower FSW } & \text { FSW 10 } & 1 / 23 / 16 & 1 / 23 / 2016 & 7 & 0.508 & 2 & 1 & 0 \\ \text { Lower FSW } & \text { FSW 10 } & 1 / 24 / 16 & 1 / 24 / 2016 & 1 & 0.254 & 3 & 3 & 2 \\ \text { Lower FSW } & \text { FSW 10 } & 1 / 29 / 16 & 1 / 29 / 2016 & 1 & 0.254 & 5 & 3 & 2 \\ \text { Lower FSW } & \text { FSW 10 } & 1 / 29 / 16 & 1 / 29 / 2016 & 1 & 0.254 & 5 & 3 & 2 \\ \text { Lower FSW } & \text { FSW 10 } & 1 / 30 / 16 & 1 / 30 / 2016 & 798 & 35.56 & 2 & 1 & 0\end{array}$




$\begin{array}{ccccccccc}\text { Lower FSW } & \text { FSW 10 } & 1 / 31 / 16 & 1 / 31 / 2016 & 70 & 1.778 & 2 & 1 & 0 \\ \text { Lower FSW } & \text { FSW 10 } & 2 / 1 / 16 & 2 / 1 / 2016 & 428 & 12.446 & 11 & 4 & 2 \\ \text { Lower FSW } & \text { FSW 10 } & 2 / 2 / 16 & 2 / 2 / 2016 & 361 & 4.826 & 6 & 4 & 4 \\ \text { Lower FSW } & \text { FSW 10 } & 2 / 3 / 16 & 2 / 3 / 2016 & 197 & 1.778 & 17 & 7 & 4 \\ \text { Lower FSW } & \text { FSW 10 } & 2 / 17 / 16 & 2 / 18 / 2016 & 1139 & 30.734 & 2 & 1 & 1 \\ \text { Lower FSW } & \text { FSW 10 } & 2 / 19 / 16 & 2 / 19 / 2016 & 1 & 0.254 & 9 & 8 & 7 \\ \text { Lower FSW } & \text { FSW 10 } & 3 / 3 / 16 & 3 / 3 / 2016 & 61 & 2.286 & 5 & 3 & 2 \\ \text { Lower FSW } & \text { FSW 10 } & 3 / 4 / 16 & 3 / 6 / 2016 & 2593 & 102.616 & 8 & 5 & 4 \\ \text { Lower FSW } & \text { FSW 10 } & 3 / 6 / 16 & 3 / 7 / 2016 & 448 & 4.318 & 3 & 2 & 2 \\ \text { Lower FSW } & \text { FSW 10 } & 3 / 7 / 16 & 3 / 7 / 2016 & 1 & 0.254 & 2 & 1 & 1 \\ \text { Lower FSW } & \text { FSW 10 } & 3 / 13 / 16 & 3 / 14 / 2016 & 1955 & 81.026 & 3 & 2 & 1 \\ \text { Lower FSW } & \text { FSW 10 } & 3 / 21 / 16 & 3 / 22 / 2016 & 866 & 20.32 & 2 & 1 & 1 \\ \text { Lower FSW } & \text { FSW 10 } & 3 / 22 / 16 & 3 / 22 / 2016 & 125 & 1.778 & 5 & 4 & 3 \\ \text { Lower FSW } & \text { FSW 10 } & 4 / 8 / 16 & 4 / 10 / 2016 & 2602 & 41.656 & 2 & 1 & 0 \\ \text { Lower FSW } & \text { FSW 10 } & 4 / 10 / 16 & 4 / 10 / 2016 & 191 & 0.762 & 11 & 8 & 7 \\ \text { Lower FSW } & \text { FSW 10 } & 4 / 22 / 16 & 4 / 24 / 2016 & 2807 & 22.86 & 8 & 8 & 7 \\ \text { Lower FSW } & \text { FSW 10 } & 4 / 24 / 16 & 4 / 24 / 2016 & 1 & 0.254 & 5 & 4 & 4 \\ \text { Lower FSW } & \text { FSW 10 } & 4 / 25 / 16 & 4 / 25 / 2016 & 1 & 0.254 & 5 & 3 & 3 \\ \text { Lower FSW } & \text { FSW 10 } & 5 / 1 / 16 & 5 / 1 / 2016 & 443 & 0.762 & 2 & 1 & 1 \\ \text { Lower FSW } & \text { FSW 10 } & 5 / 7 / 16 & 5 / 7 / 2016 & 1 & 0.254 & 2 & 1 & 1 \\ \text { Lower FSW } & \text { FSW 10 } & 5 / 7 / 16 & 5 / 7 / 2016 & 435 & 0.762 & 2 & 1 & 0 \\ \text { Lower FSW } & \text { FSW 10 } & 5 / 8 / 16 & 5 / 8 / 2016 & 1 & 0.254 & 8 & 6 & 4 \\ \text { Lower FSW } & \text { FSW 10 } & 5 / 8 / 16 & 5 / 8 / 2016 & 1 & 0.254 & 2 & 1 & 0 \\ \text { Lower FSW } & \text { FSW 10 } & 5 / 20 / 16 & 5 / 20 / 2016 & 1 & 0.254 & 2 & 1 & 0 \\ \text { Lower FSW } & \text { FSW 10 } & 5 / 21 / 16 & 5 / 21 / 2016 & 1 & 0.254 & 2 & 1 & 0 \\ \text { Upper FSW } & \text { FSW 12.13 } & 11 / 24 / 15 & 11 / 24 / 2015 & 101 & 6.096 & 2 & 1 & 0\end{array}$




$\begin{array}{ccccccccc}\text { Upper FSW } & \text { FSW 12.13 } & 11 / 26 / 15 & 11 / 26 / 2015 & 472 & 6.096 & 3 & 2 & 2 \\ \text { Upper FSW } & \text { FSW 12.13 } & 11 / 27 / 15 & 11 / 27 / 2015 & 126 & 1.016 & 2 & 2 & 1 \\ \text { Upper FSW } & \text { FSW 12.13 } & 11 / 27 / 15 & 11 / 27 / 2015 & 1 & 0.254 & 2 & 1 & 1 \\ \text { Upper FSW } & \text { FSW 12.13 } & 12 / 3 / 15 & 12 / 3 / 2015 & 114 & 5.08 & 2 & 1 & 1 \\ \text { Upper FSW } & \text { FSW 12.13 } & 12 / 10 / 15 & 12 / 10 / 2015 & 909 & 24.638 & 2 & 1 & 0 \\ \text { Upper FSW } & \text { FSW 12.13 } & 12 / 12 / 15 & 12 / 13 / 2015 & 1029 & 23.368 & 2 & 1 & 1 \\ \text { Upper FSW } & \text { FSW 12.13 } & 12 / 13 / 15 & 12 / 13 / 2015 & 93 & 6.096 & 15 & 8 & 7 \\ \text { Upper FSW } & \text { FSW 12.13 } & 12 / 14 / 15 & 12 / 14 / 2015 & 395 & 7.112 & 3 & 3 & 3 \\ \text { Upper FSW } & \text { FSW 12.13 } & 12 / 15 / 15 & 12 / 15 / 2015 & 404 & 3.302 & 3 & 2 & 1 \\ \text { Upper FSW } & \text { FSW 12.13 } & 12 / 16 / 15 & 12 / 16 / 2015 & 246 & 2.286 & 5 & 2 & 2 \\ \text { Upper FSW } & \text { FSW 12.13 } & 12 / 17 / 15 & 12 / 17 / 2015 & 1 & 0.254 & 2 & 1 & 0 \\ \text { Upper FSW } & \text { FSW 12.13 } & 12 / 19 / 15 & 12 / 19 / 2015 & 672 & 13.716 & 3 & 1 & 1 \\ \text { Upper FSW } & \text { FSW 12.13 } & 12 / 20 / 15 & 12 / 22 / 2015 & 2954 & 179.832 & 2 & 1 & 0 \\ \text { Upper FSW } & \text { FSW 12.13 } & 12 / 22 / 15 & 12 / 23 / 2015 & 232 & 0.508 & 2 & 1 & 0 \\ \text { Upper FSW } & \text { FSW 12.13 } & 12 / 23 / 15 & 12 / 23 / 2015 & 86 & 1.016 & 2 & 1 & 0 \\ \text { Upper FSW } & \text { FSW 12.13 } & 12 / 25 / 15 & 12 / 25 / 2015 & 436 & 7.112 & 11 & 5 & 3 \\ \text { Upper FSW } & \text { FSW 12.13 } & 12 / 26 / 15 & 12 / 26 / 2015 & 256 & 1.778 & 3 & 2 & 2 \\ \text { Upper FSW } & \text { FSW 12.13 } & 12 / 27 / 15 & 12 / 27 / 2015 & 212 & 1.27 & 2 & 1 & 1 \\ \text { Upper FSW } & \text { FSW 12.13 } & 12 / 28 / 15 & 12 / 28 / 2015 & 145 & 0.762 & 8 & 5 & 4 \\ \text { Upper FSW } & \text { FSW 12.13 } & 1 / 4 / 16 & 1 / 4 / 2016 & 1 & 0.254 & 2 & 1 & 0 \\ \text { Upper FSW } & \text { FSW 12.13 } & 1 / 5 / 16 & 1 / 5 / 2016 & 848 & 27.94 & 8 & 4 & 2 \\ \text { Upper FSW } & \text { FSW 12.13 } & 1 / 8 / 16 & 1 / 8 / 2016 & 280 & 4.572 & 2 & 1 & 0 \\ \text { Upper FSW } & \text { FSW 12.13 } & 1 / 9 / 16 & 1 / 10 / 2016 & 1757 & 27.432 & 3 & 2 & 2 \\ \text { Upper FSW } & \text { FSW 12.13 } & 1 / 13 / 16 & 1 / 13 / 2016 & 158 & 3.81 & 2 & 1 & 0 \\ \text { Upper FSW } & \text { FSW 12.13 } & 1 / 14 / 16 & 1 / 15 / 2016 & 938 & 21.844 & 2 & 1 & 0 \\ \text { Upper FSW } & \text { FSW 12.13 } & 1 / 16 / 16 & 1 / 16 / 2016 & 793 & 9.398 & 2 & 1 & 0\end{array}$




\begin{tabular}{|c|c|c|c|c|c|c|c|}
\hline Upper FSW & FSW 12.13 & $1 / 17 / 16$ & $1 / 18 / 2016$ & 571 & 27.686 & 2 & 1 \\
\hline Upper FSW & FSW 12.13 & $1 / 19 / 16$ & $1 / 19 / 2016$ & 551 & 25.908 & 2 & 1 \\
\hline Upper FSW & FSW 12.13 & $1 / 22 / 16$ & $1 / 23 / 2016$ & 1234 & 40.64 & 2 & 1 \\
\hline Upper FSW & FSW 12.13 & $1 / 23 / 16$ & $1 / 23 / 2016$ & 5 & 0.508 & 2 & 1 \\
\hline Upper FSW & FSW 12.13 & $1 / 24 / 16$ & $1 / 24 / 2016$ & 1 & 0.254 & 2 & 1 \\
\hline Upper FSW & FSW 12.13 & $1 / 29 / 16$ & $1 / 29 / 2016$ & 1 & 0.254 & 2 & 1 \\
\hline Upper FSW & FSW 12.13 & $1 / 29 / 16$ & $1 / 30 / 2016$ & 840 & 33.274 & 2 & 1 \\
\hline Upper FSW & FSW 12.13 & $1 / 31 / 16$ & $1 / 31 / 2016$ & 1 & 0.254 & 3 & 2 \\
\hline Upper FSW & FSW 12.13 & $1 / 31 / 16$ & $1 / 31 / 2016$ & 62 & 1.016 & 2 & 1 \\
\hline Upper FSW & FSW 12.13 & $2 / 1 / 16$ & 2/1/2016 & 468 & 9.398 & 2 & 1 \\
\hline Upper FSW & FSW 12.13 & $2 / 2 / 16$ & $2 / 2 / 2016$ & 415 & 4.064 & 5 & 4 \\
\hline Upper FSW & FSW 12.13 & $2 / 3 / 16$ & $2 / 3 / 2016$ & 266 & 2.286 & 11 & 5 \\
\hline Upper FSW & FSW 12.13 & $2 / 4 / 16$ & 2/4/2016 & 1 & 0.254 & 8 & 4 \\
\hline Upper FSW & FSW 12.13 & $2 / 17 / 16$ & $2 / 17 / 2016$ & 108 & 5.842 & 2 & 1 \\
\hline Upper FSW & FSW 12.13 & $2 / 18 / 16$ & $2 / 18 / 2016$ & 418 & 17.526 & 2 & 1 \\
\hline Upper FSW & FSW 12.13 & $2 / 19 / 16$ & $2 / 19 / 2016$ & 492 & 3.302 & 2 & 1 \\
\hline Upper FSW & FSW 12.13 & $3 / 3 / 16$ & $3 / 3 / 2016$ & 128 & 2.286 & 2 & 1 \\
\hline Upper FSW & FSW 12.13 & $3 / 4 / 16$ & $3 / 6 / 2016$ & 2470 & 100.33 & 3 & 2 \\
\hline Upper FSW & FSW 12.13 & $3 / 6 / 16$ & $3 / 7 / 2016$ & 913 & 11.684 & 9 & 5 \\
\hline Upper FSW & FSW 12.13 & $3 / 11 / 16$ & $3 / 11 / 2016$ & 322 & 12.7 & 5 & 2 \\
\hline Upper FSW & FSW 12.13 & $3 / 11 / 16$ & $3 / 11 / 2016$ & 1 & 0.254 & 3 & 1 \\
\hline Upper FSW & FSW 12.13 & $3 / 12 / 16$ & $3 / 12 / 2016$ & 423 & 25.4 & 2 & 1 \\
\hline Upper FSW & FSW 12.13 & $3 / 12 / 16$ & $3 / 14 / 2016$ & 2073 & 77.47 & 2 & 1 \\
\hline Upper FSW & FSW 12.13 & $3 / 21 / 16$ & $3 / 22 / 2016$ & 836 & 17.78 & 5 & 3 \\
\hline Upper FSW & FSW 12.13 & $3 / 22 / 16$ & $3 / 22 / 2016$ & 48 & 1.778 & 3 & 3 \\
\hline Upper FSW & FSW 12.13 & $4 / 8 / 16$ & $4 / 10 / 2016$ & 2278 & 37.592 & 3 & 2 \\
\hline
\end{tabular}




$\begin{array}{ccccccccc}\text { Upper FSW } & \text { FSW 12.13 } & 4 / 10 / 16 & 4 / 10 / 2016 & 1 & 0.254 & 3 & 1 & 1 \\ \text { Upper FSW } & \text { FSW 12.13 } & 4 / 22 / 16 & 4 / 23 / 2016 & 952 & 23.876 & 2 & 1 & 0 \\ \text { Upper FSW } & \text { FSW 12.13 } & 4 / 24 / 16 & 4 / 24 / 2016 & 1 & 0.254 & 2 & 1 & 0 \\ \text { Upper FSW } & \text { FSW 12.13 } & 5 / 1 / 16 & 5 / 1 / 2016 & 93 & 3.302 & 2 & 1 & 0 \\ \text { Upper FSW } & \text { FSW 12.13 } & 5 / 7 / 16 & 5 / 7 / 2016 & 493 & 2.54 & 3 & 2 & 1 \\ \text { Upper FSW } & \text { FSW 12.13 } & 5 / 20 / 16 & 5 / 20 / 2016 & 16 & 0.508 & 3 & 3 & 2 \\ \text { Triple A } & \text { ASW 4.5 } & 9 / 14 / 15 & 9 / 15 / 2015 & 326 & 0.762 & 2 & 1 & 1 \\ \text { Triple A } & \text { ASW 4.5 } & 9 / 15 / 15 & 9 / 15 / 2015 & 1 & 0.254 & 2 & 1 & 1 \\ \text { Triple A } & \text { ASW 4.5 } & 10 / 1 / 15 & 10 / 1 / 2015 & 222 & 12.954 & 2 & 1 & 0 \\ \text { Triple A } & \text { ASW 4.5 } & 10 / 15 / 15 & 10 / 15 / 2015 & 21 & 1.524 & 6 & 4 & 3 \\ \text { Triple A } & \text { ASW 4.5 } & 10 / 16 / 15 & 10 / 16 / 2015 & 88 & 3.556 & 23 & 11 & 7 \\ \text { Triple A } & \text { ASW 4.5 } & 10 / 17 / 15 & 10 / 17 / 2015 & 249 & 10.668 & 3 & 2 & 2 \\ \text { Triple A } & \text { ASW 4.5 } & 10 / 18 / 15 & 10 / 18 / 2015 & 6 & 1.016 & 6 & 4 & 2 \\ \text { Triple A } & \text { ASW 4.5 } & 10 / 18 / 15 & 10 / 18 / 2015 & 1 & 0.254 & 2 & 1 & 0 \\ \text { Triple A } & \text { ASW 4.5 } & 10 / 28 / 15 & 10 / 28 / 2015 & 179 & 7.112 & 3 & 3 & 2 \\ \text { Triple A } & \text { ASW 4.5 } & 10 / 28 / 15 & 10 / 28 / 2015 & 510 & 10.414 & 2 & 1 & 0 \\ \text { Triple A } & \text { ASW 4.5 } & 11 / 2 / 15 & 11 / 3 / 2015 & 1858 & 58.674 & 2 & 1 & 0 \\ \text { Triple A } & \text { ASW 4.5 } & 11 / 8 / 15 & 11 / 9 / 2015 & 432 & 13.462 & 6 & 4 & 3 \\ \text { Triple A } & \text { ASW 4.5 } & 11 / 9 / 15 & 11 / 9 / 2015 & 476 & 5.08 & 3 & 2 & 1 \\ \text { Triple A } & \text { ASW 4.5 } & 11 / 10 / 15 & 11 / 10 / 2015 & 221 & 5.334 & 2 & 1 & 1 \\ \text { Triple A } & \text { ASW 4.5 } & 11 / 15 / 15 & 11 / 15 / 2015 & 371 & 8.636 & 8 & 5 & 5 \\ \text { Triple A } & \text { ASW 4.5 } & 11 / 16 / 15 & 11 / 16 / 2015 & 480 & 15.748 & 2 & 1 & 1 \\ \text { Triple A } & \text { ASW 4.5 } & 11 / 17 / 15 & 11 / 17 / 2015 & 122 & 1.27 & 3 & 2 & 2 \\ \text { Triple A } & \text { ASW 4.5 } & 11 / 24 / 15 & 11 / 24 / 2015 & 134 & 9.398 & 2 & 1 & 1 \\ \text { Triple A } & \text { ASW 4.5 } & 11 / 25 / 15 & 11 / 25 / 2015 & 312 & 1.016 & 6 & 4 & 3 \\ \text { Triple A } & \text { ASW 4.5 } & 11 / 26 / 15 & 11 / 26 / 2015 & 401 & 10.16 & 11 & 9 & 8 \\ & & & & & & & & \end{array}$




\begin{tabular}{|c|c|c|c|c|c|c|c|}
\hline Triple A & ASW 4.5 & $11 / 27 / 15$ & $11 / 27 / 2015$ & 194 & 2.032 & 3 & 1 \\
\hline Triple A & ASW 4.5 & $11 / 28 / 15$ & $11 / 28 / 2015$ & 159 & 0.762 & 8 & 6 \\
\hline Triple A & ASW 4.5 & $12 / 3 / 15$ & $12 / 3 / 2015$ & 283 & 6.35 & 12 & 7 \\
\hline Triple A & ASW 4.5 & $12 / 10 / 15$ & $12 / 10 / 2015$ & 503 & 19.05 & 3 & 2 \\
\hline Triple A & ASW 4.5 & $12 / 11 / 15$ & $12 / 11 / 2015$ & 344 & 11.938 & 2 & 2 \\
\hline Triple A & ASW 4.5 & $12 / 12 / 15$ & $12 / 12 / 2015$ & 729 & 10.922 & 2 & 1 \\
\hline Triple A & ASW 4.5 & $12 / 13 / 15$ & $12 / 13 / 2015$ & 616 & 12.446 & 5 & 3 \\
\hline Triple A & ASW 4.5 & $12 / 14 / 15$ & $12 / 14 / 2015$ & 508 & 13.716 & 2 & 1 \\
\hline Triple A & ASW 4.5 & $12 / 15 / 15$ & $12 / 15 / 2015$ & 327 & 2.54 & 2 & 1 \\
\hline Triple A & ASW 4.5 & $12 / 16 / 15$ & $12 / 16 / 2015$ & 225 & 1.016 & 3 & 2 \\
\hline Triple A & ASW 4.5 & $12 / 19 / 15$ & $12 / 19 / 2015$ & 685 & 10.16 & 3 & 3 \\
\hline Triple A & ASW 4.5 & $12 / 20 / 15$ & $12 / 22 / 2015$ & 3011 & 89.662 & 3 & 3 \\
\hline Triple A & ASW 4.5 & $12 / 23 / 15$ & $12 / 23 / 2015$ & 338 & 1.016 & 3 & 2 \\
\hline Triple A & ASW 4.5 & $12 / 24 / 15$ & $12 / 24 / 2015$ & 1 & 0.254 & 2 & 1 \\
\hline Triple A & ASW 4.5 & $12 / 25 / 15$ & $12 / 25 / 2015$ & 428 & 9.652 & 2 & 1 \\
\hline Triple A & ASW 4.5 & $12 / 26 / 15$ & $12 / 26 / 2015$ & 306 & 6.604 & 2 & 1 \\
\hline Triple A & ASW 4.5 & $12 / 27 / 15$ & $12 / 27 / 2015$ & 165 & 1.016 & 2 & 1 \\
\hline Triple A & ASW 4.5 & $12 / 28 / 15$ & $12 / 28 / 2015$ & 13 & 0.508 & 11 & 4 \\
\hline Triple A & ASW 4.5 & $1 / 4 / 16$ & $1 / 4 / 2016$ & 39 & 0.508 & 12 & 8 \\
\hline Triple A & ASW 4.5 & $1 / 5 / 16$ & $1 / 5 / 2016$ & 897 & 26.416 & 3 & 3 \\
\hline Triple A & ASW 4.5 & $1 / 6 / 16$ & $1 / 7 / 2016$ & 716 & 1.27 & 5 & 3 \\
\hline Triple A & ASW 4.5 & $1 / 7 / 16$ & $1 / 7 / 2016$ & 529 & 20.066 & 8 & 6 \\
\hline Triple A & ASW 4.5 & $1 / 8 / 16$ & $1 / 8 / 2016$ & 451 & 18.034 & 11 & 6 \\
\hline Triple A & ASW 4.5 & 1/9/16 & $1 / 9 / 2016$ & 488 & 7.62 & 2 & 1 \\
\hline Triple A & ASW 4.5 & $1 / 10 / 16$ & $1 / 10 / 2016$ & 624 & 3.048 & 5 & 2 \\
\hline Triple A & ASW 4.5 & $1 / 13 / 16$ & $1 / 13 / 2016$ & 206 & 1.778 & 2 & 1 \\
\hline
\end{tabular}




\begin{tabular}{|c|c|c|c|c|c|c|c|}
\hline Triple A & ASW 4.5 & $1 / 14 / 16$ & $1 / 15 / 2016$ & 838 & 14.732 & 2 & 1 \\
\hline Triple A & ASW 4.5 & $1 / 16 / 16$ & $1 / 16 / 2016$ & 389 & 6.35 & 3 & 3 \\
\hline Triple A & ASW 4.5 & $1 / 16 / 16$ & $1 / 16 / 2016$ & 21 & 2.794 & 9 & 6 \\
\hline Triple A & ASW 4.5 & $1 / 17 / 16$ & $1 / 17 / 2016$ & 1 & 0.254 & 2 & 2 \\
\hline Triple A & ASW 4.5 & $1 / 18 / 16$ & $1 / 18 / 2016$ & 665 & 23.876 & 2 & 1 \\
\hline Triple A & ASW 4.5 & $1 / 19 / 16$ & $1 / 19 / 2016$ & 513 & 26.67 & 5 & 4 \\
\hline Triple A & ASW 4.5 & $1 / 22 / 16$ & $1 / 23 / 2016$ & 1263 & 48.26 & 8 & 7 \\
\hline Triple A & ASW 4.5 & $1 / 23 / 16$ & $1 / 23 / 2016$ & 59 & 0.762 & 3 & 2 \\
\hline Triple A & ASW 4.5 & $1 / 29 / 16$ & $1 / 29 / 2016$ & 1 & 0.254 & 6 & 4 \\
\hline Triple A & ASW 4.5 & $1 / 30 / 16$ & $1 / 30 / 2016$ & 810 & 33.02 & 2 & 1 \\
\hline Triple A & ASW 4.5 & $1 / 31 / 16$ & $1 / 31 / 2016$ & 1 & 0.254 & 5 & 2 \\
\hline Triple A & ASW 4.5 & $1 / 31 / 16$ & $1 / 31 / 2016$ & 216 & 0.762 & 2 & 1 \\
\hline Triple A & ASW 4.5 & $2 / 1 / 16$ & $2 / 1 / 2016$ & 442 & 17.78 & 5 & 3 \\
\hline Triple A & ASW 4.5 & $2 / 2 / 16$ & $2 / 2 / 2016$ & 394 & 5.334 & 3 & 2 \\
\hline Triple A & ASW 4.5 & $2 / 3 / 16$ & $2 / 3 / 2016$ & 107 & 1.016 & 2 & 1 \\
\hline Triple A & ASW 4.5 & $2 / 17 / 16$ & $2 / 17 / 2016$ & 1 & 0.254 & 17 & 16 \\
\hline Triple A & ASW 4.5 & $2 / 17 / 16$ & $2 / 18 / 2016$ & 149 & 10.668 & 15 & 12 \\
\hline Triple A & ASW 4.5 & $2 / 18 / 16$ & $2 / 18 / 2016$ & 347 & 20.066 & 9 & 6 \\
\hline Triple A & ASW 4.5 & $2 / 19 / 16$ & 2/19/2016 & 123 & 1.016 & 20 & 13 \\
\hline Triple A & ASW 4.5 & $3 / 3 / 16$ & $3 / 3 / 2016$ & 54 & 5.334 & 8 & 5 \\
\hline Triple A & ASW 4.5 & $3 / 4 / 16$ & $3 / 6 / 2016$ & 2631 & 125.476 & 12 & 5 \\
\hline Triple A & ASW 4.5 & $3 / 6 / 16$ & $3 / 7 / 2016$ & 507 & 1.524 & 12 & 10 \\
\hline Triple A & ASW 4.5 & $3 / 7 / 16$ & $3 / 7 / 2016$ & 534 & 10.414 & 12 & 6 \\
\hline Triple A & ASW 4.5 & $3 / 11 / 16$ & $3 / 11 / 2016$ & 318 & 21.844 & 40 & 23 \\
\hline Triple A & ASW 4.5 & $3 / 12 / 16$ & $3 / 12 / 2016$ & 260 & 12.7 & 23 & 18 \\
\hline Triple A & ASW 4.5 & $3 / 13 / 16$ & $3 / 14 / 2016$ & 1932 & 37.338 & 2 & 1 \\
\hline
\end{tabular}




$\begin{array}{ccccccccc}\text { Triple A } & \text { ASW 4.5 } & 3 / 21 / 16 & 3 / 22 / 2016 & 879 & 13.97 & 23 & 14 & 10 \\ \text { Triple A } & \text { ASW 4.5 } & 3 / 22 / 16 & 3 / 22 / 2016 & 101 & 4.064 & 26 & 13 & 7 \\ \text { Triple A } & \text { ASW 4.5 } & 3 / 28 / 16 & 3 / 28 / 2016 & 64 & 0.762 & 26 & 14 & 7 \\ \text { Triple A } & \text { ASW 4.5 } & 3 / 30 / 16 & 3 / 30 / 2016 & 15 & 0.508 & 11 & 8 & 7 \\ \text { Triple A } & \text { ASW 4.5 } & 4 / 8 / 16 & 4 / 10 / 2016 & 2439 & 49.276 & 8 & 7 & 6 \\ \text { Triple A } & \text { ASW 4.5 } & 4 / 10 / 16 & 4 / 10 / 2016 & 1 & 0.254 & 6 & 6 & 5 \\ \text { Triple A } & \text { ASW 4.5 } & 4 / 22 / 16 & 4 / 23 / 2016 & 716 & 39.37 & 9 & 7 & 6 \\ \text { Triple A } & \text { ASW 4.5 } & 4 / 23 / 16 & 4 / 23 / 2016 & 1 & 0.254 & 11 & 8 & 8 \\ \text { Triple A } & \text { ASW 4.5 } & 4 / 24 / 16 & 4 / 24 / 2016 & 1 & 0.254 & 11 & 8 & 7 \\ \text { Triple A } & \text { ASW 4.5 } & 4 / 25 / 16 & 4 / 25 / 2016 & 1 & 0.254 & 15 & 11 & 8 \\ \text { Triple A } & \text { ASW 4.5 } & 4 / 27 / 16 & 4 / 27 / 2016 & 89 & 0.762 & 15 & 13 & 12 \\ \text { Triple A } & \text { ASW 4.5 } & 4 / 28 / 16 & 4 / 28 / 2016 & 1 & 0.254 & 8 & 7 & 6 \\ \text { Triple A } & \text { ASW 4.5 } & 5 / 1 / 16 & 5 / 1 / 2016 & 182 & 5.334 & 12 & 7 & 5 \\ \text { Triple A } & \text { ASW 4.5 } & 5 / 5 / 16 & 5 / 5 / 2016 & 1 & 0.254 & 6 & 4 & 3 \\ \text { Triple A } & \text { ASW 4.5 } & 5 / 6 / 16 & 5 / 6 / 2016 & 1 & 0.254 & 29 & 19 & 13 \\ \text { Triple A } & \text { ASW 4.5 } & 5 / 6 / 16 & 5 / 6 / 2016 & 111 & 2.032 & 14 & 12 & 9 \\ \text { Triple A } & \text { ASW 4.5 } & 5 / 7 / 16 & 5 / 7 / 2016 & 607 & 6.604 & 21 & 14 & 11 \\ \text { Triple A } & \text { ASW 4.5 } & 5 / 8 / 16 & 5 / 8 / 2016 & 1 & 0.254 & 9 & 6 & 5 \\ \text { Triple A } & \text { ASW 4.5 } & 5 / 20 / 16 & 5 / 20 / 2016 & 1 & 0.254 & 9 & 7 & 6 \\ \text { Triple A } & \text { ASW 4.5 } & 5 / 21 / 16 & 5 / 21 / 2016 & 185 & 3.048 & 12 & 9 & 9 \\ \text { Triple A } & \text { ASW 4.5 } & 5 / 22 / 16 & 5 / 22 / 2016 & 1 & 0.254 & 6 & 6 & 5 \\ \text { Lower FSW } & \text { FSW 11 } & 7 / 31 / 15 & 7 / 31 / 2015 & 7 & 0.762 & 12 & 10 & 8 \\ \text { Lower FSW } & \text { FSW 11 } & 9 / 14 / 15 & 9 / 14 / 2015 & 1 & 0.254 & 11 & 4 & 2 \\ \text { Lower FSW } & \text { FSW 11 } & 9 / 15 / 15 & 9 / 15 / 2015 & 1 & 0.254 & 8 & 6 & 6 \\ \text { Lower FSW } & \text { FSW 11 } & 10 / 1 / 15 & 10 / 1 / 2015 & 289 & 22.352 & 11 & 9 & 7 \\ \text { Lower FSW } & \text { FSW 11 } & 10 / 17 / 15 & 10 / 17 / 2015 & 237 & 2.032 & 15 & 9 & 9\end{array}$




$\begin{array}{lcccccccc}\text { Lower FSW } & \text { FSW 11 } & 10 / 18 / 15 & 10 / 18 / 2015 & 1 & 0.254 & 21 & 12 & 9 \\ \text { Lower FSW } & \text { FSW 11 } & 10 / 28 / 15 & 10 / 28 / 2015 & 401 & 10.414 & 3 & 2 & 2 \\ \text { Lower FSW } & \text { FSW 11 } & 10 / 28 / 15 & 10 / 28 / 2015 & 224 & 2.032 & 15 & 11 & 9 \\ \text { Lower FSW } & \text { FSW 11 } & 11 / 2 / 15 & 11 / 3 / 2015 & 1459 & 62.23 & 5 & 4 & 3 \\ \text { Lower FSW } & \text { FSW 11 } & 11 / 3 / 15 & 11 / 3 / 2015 & 11 & 0.508 & 17 & 7 & 6 \\ \text { Lower FSW } & \text { FSW 11 } & 11 / 8 / 15 & 11 / 9 / 2015 & 348 & 21.59 & 6 & 5 & 5 \\ \text { Lower FSW } & \text { FSW 11 } & 11 / 9 / 15 & 11 / 9 / 2015 & 466 & 6.604 & 5 & 3 & 3 \\ \text { Lower FSW } & \text { FSW 11 } & 11 / 10 / 15 & 11 / 10 / 2015 & 222 & 9.906 & 3 & 2 & 2 \\ \text { Lower FSW } & \text { FSW 11 } & 11 / 15 / 15 & 11 / 15 / 2015 & 536 & 23.114 & 6 & 5 & 4 \\ \text { Lower FSW } & \text { FSW 11 } & 11 / 16 / 15 & 11 / 16 / 2015 & 377 & 8.382 & 11 & 8 & 7 \\ \text { Lower FSW } & \text { FSW 11 } & 11 / 17 / 15 & 11 / 17 / 2015 & 98 & 0.762 & 11 & 7 & 5 \\ \text { Lower FSW } & \text { FSW 11 } & 11 / 24 / 15 & 11 / 24 / 2015 & 264 & 10.16 & 5 & 3 & 2 \\ \text { Lower FSW } & \text { FSW 11 } & 11 / 25 / 15 & 11 / 25 / 2015 & 295 & 1.778 & 12 & 9 & 9 \\ \text { Lower FSW } & \text { FSW 11 } & 11 / 26 / 15 & 11 / 26 / 2015 & 210 & 3.048 & 9 & 7 & 6 \\ \text { Lower FSW } & \text { FSW 11 } & 12 / 3 / 15 & 12 / 3 / 2015 & 110 & 4.064 & 8 & 6 & 4 \\ \text { Lower FSW } & \text { FSW 11 } & 12 / 10 / 15 & 12 / 10 / 2015 & 931 & 26.924 & 11 & 5 & 2 \\ \text { Lower FSW } & \text { FSW 11 } & 12 / 11 / 15 & 12 / 11 / 2015 & 363 & 23.368 & 9 & 7 & 6 \\ \text { Lower FSW } & \text { FSW 11 } & 12 / 12 / 15 & 12 / 13 / 2015 & 977 & 12.446 & 12 & 9 & 7 \\ \text { Lower FSW } & \text { FSW 11 } & 12 / 13 / 15 & 12 / 13 / 2015 & 542 & 10.922 & 15 & 10 & 9 \\ \text { Lower FSW } & \text { FSW 11 } & 12 / 14 / 15 & 12 / 14 / 2015 & 1 & 0.254 & 17 & 11 & 9 \\ \text { Lower FSW } & \text { FSW 11 } & 12 / 14 / 15 & 12 / 14 / 2015 & 384 & 8.89 & 27 & 14 & 12 \\ \text { Lower FSW } & \text { FSW 11 } & 12 / 15 / 15 & 12 / 15 / 2015 & 160 & 1.524 & 9 & 9 & 7 \\ \text { Lower FSW } & \text { FSW 11 } & 12 / 16 / 15 & 12 / 16 / 2015 & 175 & 1.27 & 6 & 5 & 5 \\ \text { Lower FSW } & \text { FSW 11 } & 12 / 19 / 15 & 12 / 19 / 2015 & 856 & 18.542 & 6 & 6 & 5 \\ \text { Lower FSW } & \text { FSW 11 } & 12 / 20 / 15 & 12 / 20 / 2015 & 59 & 0.508 & 15 & 7 & 5 \\ \text { Lower FSW } & \text { FSW 11 } & 12 / 20 / 15 & 12 / 22 / 2015 & 2537 & 198.628 & 11 & 7 & 5\end{array}$




$\begin{array}{llccccccc}\text { Lower FSW } & \text { FSW 11 } & 12 / 22 / 15 & 12 / 23 / 2015 & 551 & 0.762 & 8 & 6 & 5 \\ \text { Lower FSW } & \text { FSW 11 } & 12 / 23 / 15 & 12 / 23 / 2015 & 1 & 0.254 & 11 & 9 & 6 \\ \text { Lower FSW } & \text { FSW 11 } & 12 / 25 / 15 & 12 / 25 / 2015 & 1 & 0.254 & 11 & 10 & 9 \\ \text { Lower FSW } & \text { FSW 11 } & 12 / 26 / 15 & 12 / 26 / 2015 & 253 & 6.35 & 9 & 7 & 5 \\ \text { Lower FSW } & \text { FSW 11 } & 12 / 27 / 15 & 12 / 27 / 2015 & 307 & 6.096 & 8 & 7 & 6 \\ \text { Lower FSW } & \text { FSW 11 } & 12 / 28 / 15 & 12 / 28 / 2015 & 284 & 1.524 & 12 & 9 & 7 \\ \text { Lower FSW } & \text { FSW 11 } & 12 / 29 / 15 & 12 / 29 / 2015 & 116 & 0.762 & 17 & 10 & 9 \\ \text { Lower FSW } & \text { FSW 11 } & 1 / 4 / 16 & 1 / 4 / 2016 & 36 & 0.508 & 18 & 13 & 10 \\ \text { Lower FSW } & \text { FSW 11 } & 1 / 5 / 16 & 1 / 5 / 2016 & 1140 & 29.718 & 27 & 14 & 11 \\ \text { Lower FSW } & \text { FSW 11 } & 1 / 6 / 16 & 1 / 7 / 2016 & 1911 & 29.21 & 20 & 11 & 8 \\ \text { Lower FSW } & \text { FSW 11 } & 1 / 8 / 16 & 1 / 8 / 2016 & 448 & 11.684 & 6 & 5 & 5 \\ \text { Lower FSW } & \text { FSW 11 } & 1 / 9 / 16 & 1 / 10 / 2016 & 1192 & 10.922 & 8 & 6 & 5 \\ \text { Lower FSW } & \text { FSW 11 } & 1 / 13 / 16 & 1 / 13 / 2016 & 284 & 4.318 & 12 & 7 & 6 \\ \text { Lower FSW } & \text { FSW 11 } & 1 / 14 / 16 & 1 / 15 / 2016 & 906 & 23.622 & 9 & 7 & 5 \\ \text { Lower FSW } & \text { FSW 11 } & 1 / 16 / 16 & 1 / 16 / 2016 & 407 & 7.112 & 8 & 6 & 5 \\ \text { Lower FSW } & \text { FSW 11 } & 1 / 16 / 16 & 1 / 16 / 2016 & 30 & 2.286 & 15 & 11 & 8 \\ \text { Lower FSW } & \text { FSW 11 } & 1 / 17 / 16 & 1 / 18 / 2016 & 550 & 26.162 & 3 & 2 & 2 \\ \text { Lower FSW } & \text { FSW 11 } & 1 / 19 / 16 & 1 / 19 / 2016 & 509 & 27.432 & 6 & 3 & 2 \\ \text { Lower FSW } & \text { FSW 11 } & 1 / 20 / 16 & 1 / 20 / 2016 & 1 & 0.254 & 5 & 2 & 2 \\ \text { Lower FSW } & \text { FSW 11 } & 1 / 22 / 16 & 1 / 23 / 2016 & 1220 & 40.386 & 2 & 1 & 1 \\ \text { Lower FSW } & \text { FSW 11 } & 1 / 23 / 16 & 1 / 23 / 2016 & 63 & 0.508 & 8 & 5 & 4 \\ \text { Lower FSW } & \text { FSW 11 } & 1 / 24 / 16 & 1 / 24 / 2016 & 33 & 0.508 & 3 & 2 & 2 \\ \text { Lower FSW } & \text { FSW 11 } & 1 / 29 / 16 & 1 / 29 / 2016 & 1 & 0.254 & 17 & 7 & 4 \\ \text { Lower FSW } & \text { FSW 11 } & 1 / 29 / 16 & 1 / 29 / 2016 & 1 & 0.254 & 6 & 5 & 4 \\ \text { Lower FSW } & \text { FSW 11 } & 1 / 29 / 16 & 1 / 30 / 2016 & 740 & 35.306 & 14 & 11 & 7 \\ \text { Lower FSW } & \text { FSW 11 } & 1 / 31 / 16 & 1 / 31 / 2016 & 937 & 10.414 & 2 & 1 & 0\end{array}$




\begin{tabular}{|c|c|c|c|c|c|c|c|}
\hline Lower FSW & FSW 11 & $2 / 1 / 16$ & $2 / 1 / 2016$ & 428 & 10.16 & 2 & 1 \\
\hline Lower FSW & FSW 11 & $2 / 2 / 16$ & $2 / 2 / 2016$ & 295 & 2.286 & 2 & 1 \\
\hline Lower FSW & FSW 11 & $2 / 17 / 16$ & $2 / 18 / 2016$ & 1184 & 33.528 & 2 & 1 \\
\hline Lower FSW & FSW 11 & $2 / 19 / 16$ & $2 / 19 / 2016$ & 92 & 1.016 & 2 & 1 \\
\hline Lower FSW & FSW 11 & $3 / 3 / 16$ & $3 / 3 / 2016$ & 60 & 2.286 & 5 & 2 \\
\hline Lower FSW & FSW 11 & $3 / 4 / 16$ & $3 / 6 / 2016$ & 2594 & 108.966 & 2 & 1 \\
\hline Lower FSW & FSW 11 & $3 / 6 / 16$ & $3 / 7 / 2016$ & 1006 & 15.494 & 2 & 1 \\
\hline Lower FSW & FSW 11 & $3 / 7 / 16$ & $3 / 7 / 2016$ & 1 & 0.254 & 2 & 1 \\
\hline Lower FSW & FSW 11 & $3 / 11 / 16$ & $3 / 12 / 2016$ & 1569 & 41.148 & 3 & 2 \\
\hline Lower FSW & FSW 11 & $3 / 13 / 16$ & $3 / 14 / 2016$ & 1955 & 81.026 & 3 & 2 \\
\hline Lower FSW & FSW 11 & $3 / 21 / 16$ & $3 / 22 / 2016$ & 1371 & 22.352 & 5 & 3 \\
\hline Lower FSW & FSW 11 & $3 / 28 / 16$ & $3 / 28 / 2016$ & 1 & 0.254 & 3 & 2 \\
\hline Lower FSW & FSW 11 & $4 / 8 / 16$ & $4 / 10 / 2016$ & 2283 & 46.228 & 9 & 6 \\
\hline Lower FSW & FSW 11 & $4 / 10 / 16$ & $4 / 10 / 2016$ & 173 & 1.016 & 2 & 1 \\
\hline Lower FSW & FSW 11 & $4 / 22 / 16$ & $4 / 23 / 2016$ & 935 & 30.226 & 9 & 5 \\
\hline Lower FSW & FSW 11 & $4 / 24 / 16$ & $4 / 24 / 2016$ & 35 & 1.016 & 2 & 1 \\
\hline Lower FSW & FSW 11 & $4 / 25 / 16$ & $4 / 25 / 2016$ & 1 & 0.254 & 5 & 2 \\
\hline Lower FSW & FSW 11 & $5 / 1 / 16$ & $5 / 1 / 2016$ & 76 & 1.016 & 3 & 2 \\
\hline Lower FSW & FSW 11 & $5 / 7 / 16$ & $5 / 7 / 2016$ & 612 & 2.54 & 5 & 2 \\
\hline Lower FSW & FSW 11 & $5 / 20 / 16$ & $5 / 20 / 2016$ & 63 & 0.762 & 5 & 3 \\
\hline Lower FSW & FSW 11 & $5 / 21 / 16$ & $5 / 21 / 2016$ & 1 & 0.254 & 5 & 2 \\
\hline Upper FSW & FSW 14 & $11 / 24 / 15$ & $11 / 24 / 2015$ & 108 & 6.858 & 5 & 4 \\
\hline Upper FSW & FSW 14 & $11 / 25 / 15$ & $11 / 25 / 2015$ & 252 & 0.762 & 2 & 1 \\
\hline Upper FSW & FSW 14 & $11 / 26 / 15$ & $11 / 26 / 2015$ & 338 & 6.35 & 2 & 1 \\
\hline Upper FSW & FSW 14 & $11 / 27 / 15$ & $11 / 27 / 2015$ & 270 & 1.016 & 8 & 5 \\
\hline Upper FSW & FSW 14 & $12 / 3 / 15$ & $12 / 3 / 2015$ & 123 & 4.826 & 5 & 3 \\
\hline
\end{tabular}




$\begin{array}{ccccccccc}\text { Upper FSW } & \text { FSW 14 } & 12 / 10 / 15 & 12 / 10 / 2015 & 923 & 27.686 & 5 & 3 & 2 \\ \text { Upper FSW } & \text { FSW 14 } & 12 / 11 / 15 & 12 / 12 / 2015 & 57 & 0.762 & 5 & 4 & 3 \\ \text { Upper FSW } & \text { FSW 14 } & 12 / 12 / 15 & 12 / 13 / 2015 & 1923 & 29.21 & 3 & 2 & 1 \\ \text { Upper FSW } & \text { FSW 14 } & 12 / 14 / 15 & 12 / 14 / 2015 & 366 & 12.446 & 6 & 5 & 4 \\ \text { Upper FSW } & \text { FSW 14 } & 12 / 15 / 15 & 12 / 15 / 2015 & 359 & 5.334 & 2 & 1 & 1 \\ \text { Upper FSW } & \text { FSW 14 } & 12 / 16 / 15 & 12 / 16 / 2015 & 257 & 3.556 & 6 & 3 & 3 \\ \text { Upper FSW } & \text { FSW 14 } & 12 / 17 / 15 & 12 / 17 / 2015 & 1 & 0.254 & 2 & 1 & 1 \\ \text { Upper FSW } & \text { FSW 14 } & 12 / 19 / 15 & 12 / 19 / 2015 & 617 & 12.7 & 5 & 3 & 3 \\ \text { Upper FSW } & \text { FSW 14 } & 12 / 20 / 15 & 12 / 22 / 2015 & 3018 & 191.262 & 6 & 4 & 3 \\ \text { Upper FSW } & \text { FSW 14 } & 12 / 22 / 15 & 12 / 22 / 2015 & 1 & 0.254 & 9 & 6 & 4 \\ \text { Upper FSW } & \text { FSW 14 } & 12 / 23 / 15 & 12 / 23 / 2015 & 1 & 0.254 & 12 & 7 & 6 \\ \text { Upper FSW } & \text { FSW 14 } & 12 / 23 / 15 & 12 / 23 / 2015 & 33 & 1.27 & 9 & 6 & 4 \\ \text { Upper FSW } & \text { FSW 14 } & 12 / 25 / 15 & 12 / 25 / 2015 & 202 & 4.064 & 3 & 1 & 1 \\ \text { Upper FSW } & \text { FSW 14 } & 12 / 26 / 15 & 12 / 26 / 2015 & 391 & 6.604 & 2 & 1 & 1 \\ \text { Upper FSW } & \text { FSW 14 } & 12 / 27 / 15 & 12 / 27 / 2015 & 321 & 3.302 & 2 & 1 & 1 \\ \text { Upper FSW } & \text { FSW 14 } & 12 / 28 / 15 & 12 / 28 / 2015 & 169 & 1.016 & 3 & 2 & 2 \\ \text { Upper FSW } & \text { FSW 14 } & 12 / 28 / 15 & 12 / 28 / 2015 & 1 & 0.254 & 2 & 1 & 0 \\ \text { Upper FSW } & \text { FSW 14 } & 12 / 29 / 15 & 12 / 29 / 2015 & 172 & 1.016 & 6 & 4 & 3 \\ \text { Upper FSW } & \text { FSW 14 } & 1 / 4 / 16 & 1 / 4 / 2016 & 28 & 0.508 & 2 & 1 & 1 \\ \text { Upper FSW } & \text { FSW 14 } & 1 / 5 / 16 & 1 / 5 / 2016 & 845 & 29.21 & 2 & 1 & 1 \\ \text { Upper FSW } & \text { FSW 14 } & 1 / 7 / 16 & 1 / 7 / 2016 & 2 & 1.778 & 3 & 1 & 1 \\ \text { Upper FSW } & \text { FSW 14 } & 1 / 8 / 16 & 1 / 8 / 2016 & 464 & 26.416 & 2 & 1 & 0 \\ \text { Upper FSW } & \text { FSW 14 } & 1 / 9 / 16 & 1 / 10 / 2016 & 1584 & 16.002 & 2 & 1 & 0 \\ \text { Upper FSW } & \text { FSW 14 } & 1 / 13 / 16 & 1 / 13 / 2016 & 215 & 4.318 & 2 & 1 & 0 \\ \text { Upper FSW } & \text { FSW 14 } & 1 / 14 / 16 & 1 / 15 / 2016 & 956 & 22.86 & 2 & 1 & 0 \\ \text { Upper FSW } & \text { FSW 14 } & 1 / 16 / 16 & 1 / 16 / 2016 & 795 & 9.906 & 17 & 8 & 6\end{array}$




\begin{tabular}{|c|c|c|c|c|c|c|c|}
\hline Upper FSW & FSW 14 & $1 / 17 / 16$ & $1 / 18 / 2016$ & 553 & 25.654 & 3 & 2 \\
\hline Upper FSW & FSW 14 & $1 / 19 / 16$ & $1 / 19 / 2016$ & 526 & 27.686 & 3 & 2 \\
\hline Upper FSW & FSW 14 & $1 / 19 / 16$ & $1 / 19 / 2016$ & 1 & 0.254 & 6 & 6 \\
\hline Upper FSW & FSW 14 & $1 / 22 / 16$ & $1 / 23 / 2016$ & 1252 & 42.418 & 2 & 1 \\
\hline Upper FSW & FSW 14 & $1 / 23 / 16$ & $1 / 23 / 2016$ & 99 & 1.016 & 6 & 4 \\
\hline Upper FSW & FSW 14 & $1 / 29 / 16$ & $1 / 29 / 2016$ & 176 & 0.508 & 12 & 6 \\
\hline Upper FSW & FSW 14 & $1 / 29 / 16$ & $1 / 30 / 2016$ & 810 & 38.1 & 2 & 1 \\
\hline Upper FSW & FSW 14 & $1 / 31 / 16$ & $1 / 31 / 2016$ & 1 & 0.254 & 6 & 5 \\
\hline Upper FSW & FSW 14 & $1 / 31 / 16$ & $1 / 31 / 2016$ & 268 & 3.048 & 2 & 1 \\
\hline Upper FSW & FSW 14 & $2 / 1 / 16$ & $2 / 1 / 2016$ & 534 & 8.89 & 11 & 7 \\
\hline Upper FSW & FSW 14 & $2 / 2 / 16$ & $2 / 2 / 2016$ & 411 & 3.81 & 2 & 1 \\
\hline Upper FSW & FSW 14 & $2 / 3 / 16$ & $2 / 3 / 2016$ & 179 & 1.524 & 5 & 3 \\
\hline Upper FSW & FSW 14 & $2 / 17 / 16$ & $2 / 17 / 2016$ & 103 & 5.842 & 3 & 3 \\
\hline Upper FSW & FSW 14 & $2 / 18 / 16$ & $2 / 18 / 2016$ & 449 & 20.828 & 3 & 2 \\
\hline Upper FSW & FSW 14 & $2 / 19 / 16$ & $2 / 19 / 2016$ & 291 & 5.08 & 14 & 9 \\
\hline Upper FSW & FSW 14 & $3 / 3 / 16$ & $3 / 3 / 2016$ & 109 & 2.286 & 2 & 1 \\
\hline Upper FSW & FSW 14 & $3 / 4 / 16$ & $3 / 6 / 2016$ & 2484 & 103.632 & 11 & 9 \\
\hline Upper FSW & FSW 14 & $3 / 6 / 16$ & $3 / 7 / 2016$ & 412 & 1.778 & 2 & 1 \\
\hline Upper FSW & FSW 14 & $3 / 7 / 16$ & $3 / 7 / 2016$ & 132 & 10.16 & 2 & 1 \\
\hline Upper FSW & FSW 14 & $3 / 11 / 16$ & $3 / 11 / 2016$ & 250 & 10.414 & 8 & 6 \\
\hline Upper FSW & FSW 14 & $3 / 12 / 16$ & $3 / 12 / 2016$ & 817 & 26.924 & 2 & 1 \\
\hline Upper FSW & FSW 14 & $3 / 12 / 16$ & $3 / 14 / 2016$ & 2042 & 78.232 & 6 & 3 \\
\hline Upper FSW & FSW 14 & $3 / 21 / 16$ & $3 / 22 / 2016$ & 847 & 19.812 & 5 & 3 \\
\hline Upper FSW & FSW 14 & $3 / 22 / 16$ & $3 / 22 / 2016$ & 31 & 1.27 & 2 & 1 \\
\hline Upper FSW & FSW 14 & $4 / 8 / 16$ & $4 / 10 / 2016$ & 2296 & 37.084 & 3 & 1 \\
\hline Upper FSW & FSW 14 & $4 / 10 / 16$ & $4 / 10 / 2016$ & 1 & 0.254 & 15 & 10 \\
\hline
\end{tabular}




\begin{tabular}{lcccccccc} 
Upper FSW & FSW 14 & $4 / 22 / 16$ & $4 / 23 / 2016$ & 1166 & 28.448 & 2 & 1 & 0 \\
Upper FSW & FSW 14 & $5 / 1 / 16$ & $5 / 1 / 2016$ & 94 & 2.54 & 2 & 1 & 0 \\
Upper FSW & FSW 14 & $5 / 7 / 16$ & $5 / 7 / 2016$ & 835 & 2.794 & 2 & 1 & 0 \\
Upper FSW & FSW 14 & $5 / 20 / 16$ & $5 / 20 / 2016$ & 45 & 0.508 & 2 & 1 & 0 \\
\hline
\end{tabular}

$\vec{w}$ 
Appendix K: Individual rill data in the Rim Fire swales. Femmons is abbreviated with "FSW". "U" indicates untrafficked class, "Mix" mixed traffic class, "Sub" subsoiled class, "FB" feller buncher tracks class, "LTS" low traffic skid trail class, and "HTS" high traffic skid trail class.

\begin{tabular}{|c|c|c|c|c|c|c|c|c|}
\hline Swale & Unit & Treatment & Flowpath type & $\begin{array}{c}\text { Connected to } \\
\text { outlet }\end{array}$ & $\begin{array}{l}\text { Length to } \\
\text { outlet (m) }\end{array}$ & $\begin{array}{c}\text { Initiation } \\
\text { Class }\end{array}$ & Year & $\begin{array}{l}\text { Segment } \\
\text { length }(\mathrm{m})\end{array}$ \\
\hline ASW1 & Triple A & Logged & Channel & Yes & 63.2 & $\mathrm{U}$ & 2015 & 63.2 \\
\hline ASW1 & Triple A & Logged & Rill & Yes & 15.3 & $\mathrm{U}$ & 2015 & 15.3 \\
\hline ASW1 & Triple A & Logged & Rill & Yes & 18.9 & $\mathrm{U}$ & 2015 & 16.3 \\
\hline ASW1 & Triple A & Logged & Rill & Yes & 21.7 & LTS & 2015 & 14.0 \\
\hline ASW1 & Triple A & Logged & Rill & Yes & 20.1 & LTS & 2015 & 11.5 \\
\hline ASW 1 & Triple A & Logged & Rill & Yes & 13.5 & $\mathrm{U}$ & 2015 & 13.5 \\
\hline ASW1 & Triple A & Logged & Rill & Yes & 39.9 & LTS & 2015 & 27.3 \\
\hline ASW1 & Triple A & Logged & Rill & Yes & 39.8 & LTS & 2015 & 25.5 \\
\hline ASW1 & Triple A & Logged & Rill & Yes & 37.1 & LTS & 2015 & 21.6 \\
\hline ASW1 & Triple A & Logged & Rill & Yes & 48 & LTS & 2015 & 30.2 \\
\hline ASW1 & Triple A & Logged & Rill & Yes & 42.2 & $\mathrm{U}$ & 2015 & 16.0 \\
\hline ASW1 & Triple A & Logged & Rill & Yes & 51.5 & $\mathrm{U}$ & 2015 & 18.3 \\
\hline ASW1 & Triple A & Logged & Rill & Yes & 67.8 & $\mathrm{U}$ & 2015 & 30.9 \\
\hline ASW1 & Triple A & Logged & Rill & Yes & 78.7 & $\mathrm{U}$ & 2015 & 19.5 \\
\hline ASW1 & Triple A & Logged & Rill & Yes & 65 & $\mathrm{U}$ & 2015 & 20.3 \\
\hline ASW1 & Triple A & Logged & Rill & Yes & 53.9 & $\mathrm{U}$ & 2015 & 9.3 \\
\hline ASW1 & Triple A & Logged & Rill & Yes & 56.2 & $\mathrm{U}$ & 2015 & 10.1 \\
\hline ASW1 & Triple A & Logged & Rill & Yes & 59.7 & $\mathrm{U}$ & 2015 & 14.9 \\
\hline ASW1 & Triple A & Logged & Rill & Yes & 55.3 & $\mathrm{U}$ & 2015 & 5.8 \\
\hline
\end{tabular}




$\begin{array}{llllccccc}\text { ASW1 } & \text { Triple A } & \text { Logged } & \text { Rill } & \text { Yes } & 110.1 & \text { HTS } & 2015 & 83.2 \\ \text { ASW1 } & \text { Triple A } & \text { Logged } & \text { Rill } & \text { Yes } & 61.9 & \text { HTS } & 2015 & 28.8 \\ \text { ASW1 } & \text { Triple A } & \text { Logged } & \text { Rill } & \text { Yes } & 66 & \text { LTS } & 2015 & 10.9 \\ \text { ASW2 } & \text { Triple A } & \text { Control } & \text { Channel } & \text { Yes } & 29.6 & \text { U } & 2015 & 29.6 \\ \text { ASW2 } & \text { Triple A } & \text { Control } & \text { Rill } & \text { Yes } & 28.5 & \text { U } & 2015 & 2.1 \\ \text { ASW2 } & \text { Triple A } & \text { Control } & \text { Rill } & \text { Yes } & 27.5 & \text { U } & 2015 & 3.5 \\ \text { ASW2 } & \text { Triple A } & \text { Control } & \text { Rill } & \text { Yes } & 24.4 & \text { U } & 2015 & 2.3 \\ \text { ASW2 } & \text { Triple A } & \text { Control } & \text { Rill } & \text { Yes } & 32.2 & \text { U } & 2015 & 9.5 \\ \text { ASW2 } & \text { Triple A } & \text { Control } & \text { Rill } & \text { Yes } & 29.5 & \text { U } & 2015 & 2.0 \\ \text { ASW2 } & \text { Triple A } & \text { Control } & \text { Rill } & \text { Yes } & 25.9 & \text { U } & 2015 & 6.0 \\ \text { ASW2 } & \text { Triple A } & \text { Control } & \text { Rill } & \text { Yes } & 20.9 & \text { U } & 2015 & 2.4 \\ \text { ASW2 } & \text { Triple A } & \text { Control } & \text { Rill } & \text { Yes } & 20.7 & \text { U } & 2015 & 2.2 \\ \text { ASW2 } & \text { Triple A } & \text { Control } & \text { Rill } & \text { Yes } & 20.7 & \text { U } & 2015 & 4.0 \\ \text { ASW2 } & \text { Triple A } & \text { Control } & \text { Rill } & \text { Yes } & 19.3 & \text { U } & 2015 & 3.8 \\ \text { ASW2 } & \text { Triple A } & \text { Control } & \text { Rill } & \text { Yes } & 10.5 & \text { U } & 2015 & 3.9 \\ \text { ASW2 } & \text { Triple A } & \text { Control } & \text { Rill } & \text { Yes } & 11 & \text { U } & 2015 & 2.4 \\ \text { ASW2 } & \text { Triple A } & \text { Control } & \text { Rill } & \text { Yes } & 21 & \text { U } & 2015 & 12.4 \\ \text { ASW2 } & \text { Triple A } & \text { Control } & \text { Rill } & \text { Yes } & 9.3 & \text { U } & 2015 & 2.1 \\ \text { ASW2 } & \text { Triple A } & \text { Control } & \text { Rill } & \text { Yes } & 17.9 & \text { U } & 2015 & 11.8 \\ \text { ASW2 } & \text { Triple A } & \text { Control } & \text { Rill } & \text { Yes } & 19.9 & \text { U } & 2015 & 15.1 \\ \text { ASW2 } & \text { Triple A } & \text { Control } & \text { Rill } & \text { Yes } & 8.7 & \text { U } & 2015 & 5.5 \\ \text { ASW2 } & \text { Triple A } & \text { Control } & \text { Rill } & \text { Yes } & 8.5 & \text { U } & 2015 & 6.6 \\ \text { ASW3 } & \text { Triple A } & \text { Logged } & \text { Rill } & \text { Yes } & 62 & \text { HTS } & 2015 & 31.6 \\ \text { ASW3 } & \text { Triple A } & \text { Logged } & \text { Rill } & \text { Yes } & 56.8 & \text { HTS } & 2015 & 4.6 \\ \text { ASW3 } & \text { Triple A } & \text { Logged } & \text { Rill } & \text { Yes } & 54 & \text { HTS } & 2015 & 7.6 \\ \text { ASW3 } & \text { Triple A } & \text { Logged } & \text { Rill } & \text { Yes } & 48 & \text { HTS } & 2015 & 11.6\end{array}$




\begin{tabular}{|c|c|c|c|c|c|c|c|c|}
\hline ASW3 & Triple A & Logged & Rill & Yes & 56.7 & HTS & 2015 & 32.7 \\
\hline ASW3 & Triple A & Logged & Rill & Yes & 45.2 & HTS & 2015 & 42.8 \\
\hline ASW3 & Triple A & Logged & Rill & Yes & 44.9 & HTS & 2015 & 12.7 \\
\hline ASW3 & Triple A & Logged & Rill & Yes & 43.6 & $\mathrm{U}$ & 2015 & 6.8 \\
\hline ASW3 & Triple A & Logged & Rill & Yes & 40.3 & $\mathrm{U}$ & 2015 & 5.1 \\
\hline ASW3 & Triple A & Logged & Rill & Yes & 26.2 & FB & 2015 & 21.1 \\
\hline ASW3 & Triple A & Logged & Rill & Yes & 35.9 & HTS & 2015 & 17.8 \\
\hline ASW3 & Triple A & Logged & Rill & Yes & 23.4 & $\mathrm{U}$ & 2015 & 17.2 \\
\hline ASW3 & Triple A & Logged & Rill & Yes & 12.1 & FB & 2015 & 12.1 \\
\hline ASW3 & Triple A & Logged & Rill & Yes & 52.7 & HTS & 2015 & 34.6 \\
\hline ASW3 & Triple A & Logged & Rill & Yes & 41.6 & HTS & 2015 & 6.0 \\
\hline ASW3 & Triple A & Logged & Channel & Yes & 30.3 & $\mathrm{U}$ & 2015 & 30.3 \\
\hline ASW3 & Triple A & Logged & Rill & Yes & 53.9 & Sub & 2016 & 18.8 \\
\hline ASW3 & Triple A & Logged & Rill & Yes & 63.7 & Sub & 2016 & 40.2 \\
\hline ASW3 & Triple A & Logged & Rill & Yes & 42.4 & Sub & 2016 & 5.4 \\
\hline ASW3 & Triple A & Logged & Rill & Yes & 65.9 & Sub & 2016 & 9.0 \\
\hline ASW3 & Triple A & Logged & Rill & Yes & 63.2 & Sub & 2016 & 7.2 \\
\hline ASW3 & Triple A & Logged & Rill & Yes & 61.9 & Sub & 2016 & 6.9 \\
\hline ASW3 & Triple A & Logged & Rill & Yes & 49.5 & Sub & 2016 & 11.5 \\
\hline ASW3 & Triple A & Logged & Rill & Yes & 46.1 & Sub & 2016 & 6.5 \\
\hline ASW3 & Triple A & Logged & Rill & Yes & 45.7 & Sub & 2016 & 43.2 \\
\hline ASW3 & Triple A & Logged & Rill & Yes & 44.4 & Sub & 2016 & 5.4 \\
\hline ASW3 & Triple A & Logged & Rill & Yes & 47 & Sub & 2016 & 16.6 \\
\hline ASW3 & Triple A & Logged & Rill & Yes & 35.4 & Sub & 2016 & 34.0 \\
\hline ASW3 & Triple A & Logged & Rill & Yes & 50.9 & Sub & 2016 & 13.0 \\
\hline ASW3 & Triple A & Logged & Rill & Yes & 49 & Sub & 2016 & 6.4 \\
\hline
\end{tabular}




$\begin{array}{llllccccc}\text { ASW3 } & \text { Triple A } & \text { Logged } & \text { Rill } & \text { Yes } & 47 & \text { Sub } & 2016 & 10.0 \\ \text { ASW3 } & \text { Triple A } & \text { Logged } & \text { Rill } & \text { Yes } & 49.3 & \text { Sub } & 2016 & 14.0 \\ \text { ASW3 } & \text { Triple A } & \text { Logged } & \text { Rill } & \text { Yes } & 56.4 & \text { HTS } & 2016 & 15.7 \\ \text { ASW3 } & \text { Triple A } & \text { Logged } & \text { Rill } & \text { Yes } & 48.6 & \text { HTS } & 2016 & 4.3 \\ \text { ASW3 } & \text { Triple A } & \text { Logged } & \text { Rill } & \text { Yes } & 45.1 & \text { U } & 2016 & 4.8 \\ \text { ASW3 } & \text { Triple A } & \text { Logged } & \text { Rill } & \text { Yes } & 41 & \text { U } & 2016 & 2.5 \\ \text { ASW3 } & \text { Triple A } & \text { Logged } & \text { Rill } & \text { Yes } & 26 & \text { FB } & 2016 & 21.0 \\ \text { ASW3 } & \text { Triple A } & \text { Logged } & \text { Rill } & \text { Yes } & 35.6 & \text { HTS } & 2016 & 17.7 \\ \text { ASW3 } & \text { Triple A } & \text { Logged } & \text { Channel } & \text { Yes } & 30.1 & \text { U } & 2016 & 30.1 \\ \text { ASW3 } & \text { Triple A } & \text { Logged } & \text { Rill } & \text { Yes } & 23.3 & \text { U } & 2016 & 17.1 \\ \text { ASW3 } & \text { Triple A } & \text { Logged } & \text { Rill } & \text { Yes } & 12.1 & \text { FB } & 2016 & 12.1 \\ \text { ASW3 } & \text { Triple A } & \text { Logged } & \text { Rill } & \text { Yes } & 37.9 & \text { U } & 2016 & 7.8 \\ \text { ASW4 } & \text { Triple A } & \text { Logged } & \text { Rill } & \text { Yes } & 9 & \text { U } & 2015 & 9.0 \\ \text { A ASW4 } & \text { Triple A } & \text { Logged } & \text { Channel } & \text { Yes } & 16.2 & \text { U } & 2015 & 16.2 \\ \text { ASW4 } & \text { Triple A } & \text { Logged } & \text { Rill } & \text { Yes } & 6.1 & \text { U } & 2015 & 6.1 \\ \text { ASW4 } & \text { Triple A } & \text { Logged } & \text { Rill } & \text { Yes } & 24 & \text { Mix } & 2015 & 7.7 \\ \text { ASW4 } & \text { Triple A } & \text { Logged } & \text { Rill } & \text { No } & 0 & \text { LTS } & 2015 & 14.5 \\ \text { ASW4 } & \text { Triple A } & \text { Logged } & \text { Rill } & \text { No } & 0 & \text { Mix } & 2015 & 7.1 \\ \text { ASW4 } & \text { Triple A } & \text { Logged } & \text { Rill } & \text { No } & 0 & \text { FB } & 2015 & 5.1 \\ \text { ASW4 } & \text { Triple A } & \text { Logged } & \text { Rill } & \text { No } & 0 & \text { FB } & 2015 & 9.7 \\ \text { ASW4 } & \text { Triple A } & \text { Logged } & \text { Rill } & \text { No } & 0 & \text { LTS } & 2015 & 7.1 \\ \text { ASW4 } & \text { Triple A } & \text { Logged } & \text { Rill } & \text { No } & 0 & \text { HTS } & 2015 & 60.6 \\ \text { ASW4 } & \text { Triple A } & \text { Logged } & \text { Rill } & \text { No } & 0 & \text { U } & 2015 & 22.0 \\ \text { ASW4 } & \text { Triple A } & \text { Logged } & \text { Rill } & \text { No } & 0 & \text { FB } & 2015 & 10.5 \\ \text { ASW4 } & \text { Triple A } & \text { Logged } & \text { Rill } & \text { Yes } & 31.8 & \text { FB } & 2015 & 15.6 \\ \text { ASW5 } & \text { Triple A } & \text { Logged } & \text { Rill } & \text { Yes } & 35.3 & \text { HTS } & 2015 & 32.3\end{array}$




\begin{tabular}{|c|c|c|c|c|c|c|c|c|}
\hline ASW5 & Triple A & Logged & Rill & Yes & 15.1 & $\mathrm{U}$ & 2015 & 13.7 \\
\hline ASW5 & Triple A & Logged & Rill & Yes & 32.5 & HTS & 2015 & 27.7 \\
\hline ASW5 & Triple A & Logged & Rill & Yes & 51.3 & HTS & 2015 & 38.6 \\
\hline ASW5 & Triple A & Logged & Rill & Yes & 17.5 & $\mathrm{U}$ & 2015 & 7.2 \\
\hline ASW5 & Triple A & Logged & Rill & Yes & 24.9 & $\mathrm{U}$ & 2015 & 12.2 \\
\hline ASW5 & Triple A & Logged & Rill & Yes & 26.2 & HTS & 2015 & 13.1 \\
\hline ASW5 & Triple A & Logged & Rill & Yes & 36.5 & HTS & 2015 & 12.9 \\
\hline ASW5 & Triple A & Logged & Rill & Yes & 38.8 & HTS & 2015 & 33.0 \\
\hline ASW5 & Triple A & Logged & Rill & Yes & 48 & HTS & 2015 & 11.7 \\
\hline ASW5 & Triple A & Logged & Rill & Yes & 47.3 & HTS & 2015 & 34.7 \\
\hline ASW5 & Triple A & Logged & Rill & Yes & 33.7 & HTS & 2015 & 25.5 \\
\hline ASW5 & Triple A & Logged & Rill & Yes & 30.4 & HTS & 2015 & 15.3 \\
\hline ASW5 & Triple A & Logged & Rill & Yes & 40.3 & HTS & 2015 & 23.4 \\
\hline ASW5 & Triple A & Logged & Rill & Yes & 35.3 & HTS & 2015 & 9.8 \\
\hline ASW5 & Triple A & Logged & Channel & Yes & 12.7 & $\mathrm{U}$ & 2015 & 12.7 \\
\hline ASW6 & Triple A & Logged & Rill & Yes & 68.4 & HTS & 2015 & 54.2 \\
\hline ASW6 & Triple A & Logged & Rill & Yes & 35.7 & HTS & 2015 & 35.7 \\
\hline ASW6 & Triple A & Logged & Rill & Yes & 36.7 & HTS & 2015 & 3.2 \\
\hline ASW6 & Triple A & Logged & Rill & Yes & 58.2 & HTS & 2015 & 44.0 \\
\hline ASW6 & Triple A & Logged & Rill & Yes & 40.3 & LTS & 2015 & 19.9 \\
\hline ASW6 & Triple A & Logged & Rill & Yes & 54.2 & HTS & 2015 & 12.3 \\
\hline ASW6 & Triple A & Logged & Rill & Yes & 54.2 & HTS & 2015 & 6.4 \\
\hline ASW6 & Triple A & Logged & Rill & Yes & 62.2 & HTS & 2015 & 6.5 \\
\hline ASW6 & Triple A & Logged & Rill & Yes & 13 & $\mathrm{U}$ & 2015 & 6.2 \\
\hline ASW6 & Triple A & Logged & Rill & Yes & 6.8 & FB & 2015 & 6.8 \\
\hline ASW6 & Triple A & Logged & Rill & Yes & 14.2 & $\mathrm{U}$ & 2015 & 14.2 \\
\hline
\end{tabular}




\begin{tabular}{|c|c|c|c|c|c|c|c|c|}
\hline ASW7 & Triple A & Control & Rill & Yes & 27 & U & 2015 & 27.0 \\
\hline ASW7 & Triple A & Control & Rill & Yes & 20.1 & $\mathrm{U}$ & 2015 & 7.4 \\
\hline ASW7 & Triple A & Control & Rill & Yes & 24.3 & U & 2015 & 24.3 \\
\hline ASW7 & Triple A & Control & Rill & Yes & 19 & U & 2015 & 19.0 \\
\hline ASW7 & Triple A & Control & Rill & Yes & 19.2 & U & 2015 & 4.5 \\
\hline ASW7 & Triple A & Control & Rill & Yes & 29.5 & U & 2015 & 23.3 \\
\hline ASW7 & Triple A & Control & Rill & Yes & 25.7 & U & 2015 & 25.7 \\
\hline ASW7 & Triple A & Control & Rill & Yes & 12.2 & U & 2015 & 12.2 \\
\hline ASW7 & Triple A & Control & Rill & No & 0 & $\mathrm{U}$ & 2015 & 15.4 \\
\hline FSW 10 & Lower FSW & Logged & Rill & Yes & 27.3 & Mix & 2016 & 27.3 \\
\hline FSW10 & Lower FSW & Logged & Rill & Yes & 32.5 & HTS & 2016 & 27.2 \\
\hline FSW 10 & Lower FSW & Logged & Rill & Yes & 8 & $\mathrm{U}$ & 2016 & 8.0 \\
\hline FSW 10 & Lower FSW & Logged & Rill & Yes & 49.4 & HTS & 2016 & 49.4 \\
\hline FSW 10 & Lower FSW & Logged & Rill & Yes & 50 & HTS & 2016 & 20.3 \\
\hline FSW 10 & Lower FSW & Logged & Rill & Yes & 48.4 & HTS & 2016 & 32.7 \\
\hline FSW 10 & Lower FSW & Logged & Rill & Yes & 27.8 & Mix & 2016 & 11.0 \\
\hline FSW 10 & Lower FSW & Logged & Rill & Yes & 16.9 & HTS & 2016 & 16.9 \\
\hline FSW 10 & Lower FSW & Logged & Rill & No & 0 & Mix & 2016 & 27.5 \\
\hline FSW 10 & Lower FSW & Logged & Rill & No & 0 & Mix & 2016 & 8.4 \\
\hline FSW 10 & Lower FSW & Logged & Rill & Yes & 9.7 & $\mathrm{U}$ & 2016 & 9.7 \\
\hline FSW11 & Lower FSW & Logged & Rill & Yes & 18.2 & FB & 2016 & 18.2 \\
\hline FSW11 & Lower FSW & Logged & Rill & No & 0 & FB & 2016 & 10.9 \\
\hline FSW11 & Lower FSW & Logged & Rill & No & 0 & HTS & 2016 & 7.2 \\
\hline FSW11 & Lower FSW & Logged & Rill & No & 0 & HTS & 2016 & 20.8 \\
\hline FSW11 & Lower FSW & Logged & Rill & No & 0 & HTS & 2016 & 13.0 \\
\hline FSW11 & Lower FSW & Logged & Rill & No & 0 & HTS & 2016 & 41.3 \\
\hline
\end{tabular}




\begin{tabular}{|c|c|c|c|c|c|c|c|c|}
\hline FSW11 & Lower FSW & Logged & Rill & No & 0 & HTS & 2016 & 12.3 \\
\hline FSW11 & Lower FSW & Logged & Rill & No & 0 & HTS & 2016 & 17.4 \\
\hline FSW11 & Lower FSW & Logged & Rill & No & 0 & HTS & 2016 & 12.4 \\
\hline FSW11 & Lower FSW & Logged & Rill & No & 0 & HTS & 2016 & 9.2 \\
\hline FSW11 & Lower FSW & Logged & Rill & No & 0 & HTS & 2016 & 13.7 \\
\hline FSW11 & Lower FSW & Logged & Rill & No & 0 & HTS & 2016 & 11.2 \\
\hline FSW11 & Lower FSW & Logged & Rill & No & 0 & HTS & 2016 & 6.0 \\
\hline FSW11 & Lower FSW & Logged & Rill & No & 0 & FB & 2016 & 7.8 \\
\hline FSW11 & Lower FSW & Logged & Rill & No & 0 & FB & 2016 & 11.3 \\
\hline FSW11 & Lower FSW & Logged & Rill & No & 0 & FB & 2016 & 15.3 \\
\hline FSW11 & Lower FSW & Logged & Rill & No & 0 & FB & 2016 & 11.5 \\
\hline FSW12 & Upper FSW & Control & Channel & Yes & 31.5 & $\mathrm{U}$ & 2016 & 31.5 \\
\hline FSW12 & Upper FSW & Control & Rill & Yes & 11.7 & U & 2016 & 8.0 \\
\hline FSW12 & Upper FSW & Control & Rill & Yes & 66.2 & U & 2016 & 53.0 \\
\hline FSW12 & Upper FSW & Control & Rill & Yes & 32.8 & U & 2016 & 18.5 \\
\hline FSW12 & Upper FSW & Control & Rill & Yes & 35.8 & U & 2016 & 20.0 \\
\hline FSW12 & Upper FSW & Control & Rill & Yes & 23 & $\mathrm{U}$ & 2016 & 8.7 \\
\hline FSW12 & Upper FSW & Control & Rill & Yes & 25.8 & U & 2016 & 3.2 \\
\hline FSW12 & Upper FSW & Control & Rill & Yes & 43.3 & U & 2016 & 20.7 \\
\hline FSW12 & Upper FSW & Control & Rill & Yes & 38.3 & U & 2016 & 7.3 \\
\hline FSW12 & Upper FSW & Control & Rill & Yes & 58.5 & U & 2016 & 27.0 \\
\hline FSW12 & Upper FSW & Control & Rill & No & 0 & U & 2016 & 14.9 \\
\hline FSW12 & Upper FSW & Control & Rill & Yes & 58.7 & U & 2016 & 12.1 \\
\hline FSW12 & Upper FSW & Control & Rill & Yes & 50 & U & 2016 & 24.9 \\
\hline FSW12 & Upper FSW & Control & Rill & Yes & 30.1 & U & 2016 & 5.4 \\
\hline FSW12 & Upper FSW & Control & Rill & Yes & 17.4 & U & 2016 & 4.2 \\
\hline
\end{tabular}




\begin{tabular}{|c|c|c|c|c|c|c|c|c|}
\hline FSW12 & Upper FSW & Control & Rill & Yes & 18.8 & U & 2016 & 9.2 \\
\hline FSW13 & Upper FSW & Logged & Channel & Yes & 73.5 & U & 2016 & 73.5 \\
\hline FSW13 & Upper FSW & Logged & Rill & Yes & 4.4 & U & 2016 & 4.4 \\
\hline FSW13 & Upper FSW & Logged & Rill & Yes & 13.5 & $\mathrm{U}$ & 2016 & 10.7 \\
\hline FSW13 & Upper FSW & Logged & Rill & Yes & 44.6 & HTS & 2016 & 41.0 \\
\hline FSW13 & Upper FSW & Logged & Rill & Yes & 46.5 & HTS & 2016 & 12.9 \\
\hline FSW13 & Upper FSW & Logged & Rill & Yes & 23.8 & $\mathrm{U}$ & 2016 & 6.8 \\
\hline FSW13 & Upper FSW & Logged & Rill & Yes & 20.5 & U & 2016 & 14.4 \\
\hline FSW13 & Upper FSW & Logged & Rill & Yes & 55.5 & U & 2016 & 35.5 \\
\hline FSW13 & Upper FSW & Logged & Rill & Yes & 41.1 & $\mathrm{U}$ & 2016 & 4.6 \\
\hline FSW13 & Upper FSW & Logged & Rill & Yes & 39.4 & U & 2016 & 12.8 \\
\hline FSW13 & Upper FSW & Logged & Rill & Yes & 60.8 & U & 2016 & 35.3 \\
\hline FSW13 & Upper FSW & Logged & Rill & Yes & 48.9 & U & 2016 & 18.8 \\
\hline$\vec{A}$ FSW13 & Upper FSW & Logged & Rill & Yes & 47 & $\mathrm{U}$ & 2016 & 10.8 \\
\hline FSW13 & Upper FSW & Logged & Rill & Yes & 104.4 & HTS & 2016 & 51.0 \\
\hline FSW13 & Upper FSW & Logged & Rill & Yes & 104.3 & HTS & 2016 & 5.8 \\
\hline FSW13 & Upper FSW & Logged & Rill & Yes & 105.3 & HTS & 2016 & 6.8 \\
\hline FSW13 & Upper FSW & Logged & Rill & Yes & 92 & $\mathrm{U}$ & 2016 & 21.6 \\
\hline FSW13 & Upper FSW & Logged & Rill & Yes & 87.9 & $\mathrm{U}$ & 2016 & 15.3 \\
\hline FSW13 & Upper FSW & Logged & Rill & Yes & 88.3 & U & 2016 & 13.1 \\
\hline FSW13 & Upper FSW & Logged & Rill & Yes & 92 & U & 2016 & 18.5 \\
\hline FSW13 & Upper FSW & Logged & Rill & Yes & 72.7 & $\mathrm{U}$ & 2016 & 9.0 \\
\hline FSW13 & Upper FSW & Logged & Rill & No & 0 & HTS & 2016 & 50.5 \\
\hline FSW 13 & Upper FSW & Logged & Rill & No & 0 & HTS & 2016 & 10.3 \\
\hline FSW13 & Upper FSW & Logged & Rill & No & 0 & HTS & 2016 & 15.6 \\
\hline FSW 13 & Upper FSW & Logged & Rill & No & 0 & HTS & 2016 & 18.3 \\
\hline
\end{tabular}




\begin{tabular}{|c|c|c|c|c|c|c|c|c|}
\hline FSW14 & Upper FSW & Control & Channel & Yes & 49 & $\mathrm{U}$ & 2016 & 49.0 \\
\hline FSW 14 & Upper FSW & Control & Rill & Yes & 31.6 & U & 2016 & 8.3 \\
\hline FSW14 & Upper FSW & Control & Rill & Yes & 29.5 & U & 2016 & 8.4 \\
\hline FSW14 & Upper FSW & Control & Rill & Yes & 25 & U & 2016 & 6.0 \\
\hline FSW14 & Upper FSW & Control & Rill & Yes & 30.7 & $\mathrm{U}$ & 2016 & 19.4 \\
\hline FSW14 & Upper FSW & Control & Rill & Yes & 41.9 & U & 2016 & 25.0 \\
\hline FSW14 & Upper FSW & Control & Rill & Yes & 41.6 & $\mathrm{U}$ & 2016 & 32.7 \\
\hline FSW14 & Upper FSW & Control & Rill & Yes & 16.4 & U & 2016 & 9.3 \\
\hline FSW14 & Upper FSW & Control & Rill & Yes & 21 & U & 2016 & 20.3 \\
\hline FSW8 & Lower FSW & Control & Rill & Yes & 29.9 & U & 2016 & 29.9 \\
\hline FSW8 & Lower FSW & Control & Rill & Yes & 16.2 & U & 2016 & 16.2 \\
\hline FSW8 & Lower FSW & Control & Rill & Yes & 19.6 & U & 2016 & 19.6 \\
\hline FSW8 & Lower FSW & Control & Rill & Yes & 24.9 & U & 2016 & 24.9 \\
\hline FSW8 & Lower FSW & Control & Rill & No & 0 & U & 2016 & 4.2 \\
\hline FSW8 & Lower FSW & Control & Rill & No & 0 & U & 2016 & 9.8 \\
\hline FSW8 & Lower FSW & Control & Rill & No & 0 & U & 2016 & 14.3 \\
\hline FSW8 & Lower FSW & Control & Rill & No & 0 & $\mathrm{U}$ & 2016 & 6.2 \\
\hline FSW8 & Lower FSW & Control & Rill & No & 0 & U & 2016 & 10.3 \\
\hline FSW8 & Lower FSW & Control & Rill & No & 0 & U & 2016 & 14.3 \\
\hline FSW8 & Lower FSW & Control & Rill & No & 0 & U & 2016 & 16.1 \\
\hline FSW9 & Lower FSW & Logged & Rill & Yes & 18.1 & FB & 2016 & 18.1 \\
\hline FSW9 & Lower FSW & Logged & Rill & Yes & 8.9 & $\mathrm{U}$ & 2016 & 8.9 \\
\hline FSW9 & Lower FSW & Logged & Rill & Yes & 22.7 & U & 2016 & 22.7 \\
\hline FSW9 & Lower FSW & Logged & Rill & Yes & 21.4 & U & 2016 & 8.6 \\
\hline FSW9 & Lower FSW & Logged & Rill & Yes & 19.7 & $\mathrm{U}$ & 2016 & 10.0 \\
\hline FSW9 & Lower FSW & Logged & Rill & Yes & 46.8 & HTS & 2016 & 46.8 \\
\hline
\end{tabular}




\begin{tabular}{|c|c|c|c|c|c|c|c|c|}
\hline FSW9 & Lower FSW & Logged & Rill & Yes & 39.2 & HTS & 2016 & 9.2 \\
\hline FSW9 & Lower FSW & Logged & Rill & Yes & 43.1 & HTS & 2016 & 11.2 \\
\hline FSW9 & Lower FSW & Logged & Rill & Yes & 18.9 & $\mathrm{U}$ & 2016 & 10.6 \\
\hline FSW9 & Lower FSW & Logged & Rill & Yes & 17.2 & U & 2016 & 10.3 \\
\hline FSW9 & Lower FSW & Logged & Rill & Yes & 13.8 & U & 2016 & 13.8 \\
\hline FSW9 & Lower FSW & Logged & Rill & Yes & 20.8 & HTS & 2016 & 20.8 \\
\hline FSW9 & Lower FSW & Logged & Rill & Yes & 26 & HTS & 2016 & 18.4 \\
\hline FSW9 & Lower FSW & Logged & Rill & Yes & 12.9 & HTS & 2016 & 4.2 \\
\hline FSW9 & Lower FSW & Logged & Rill & No & 0 & HTS & 2016 & 9.7 \\
\hline FSW9 & Lower FSW & Logged & Rill & No & 0 & FB & 2016 & 12.3 \\
\hline
\end{tabular}

$\underset{\infty}{+}$ 
Appendix L: Annual sediment yield for the Rim Fire swales. Femmons is abbreviated by "FSW". NA indicates logging had not occurred and fences were not installed for the water year. Lower Femmons monitoring only began after July 2015.

\begin{tabular}{ccccc}
\hline Unit & Swale & Treatment & $\begin{array}{c}\text { WY 2015 Yield (Mg } \\
\left.\text { ha }^{-1}\right)\end{array}$ & WY 2016 Yield $\left(\mathrm{Mg} \mathrm{ha}^{-1}\right)$ \\
\hline Triple A & ASW 1 & Logged & 2.84 & 1.10 \\
Triple A & ASW 2 & Control & 1.76 & 0.04 \\
Triple A & ASW 3 & Logged & 2.71 & 3.16 \\
Triple A & ASW 4 & Logged & 0.26 & 0.14 \\
Triple A & ASW 5 & Logged & 8.14 & 1.24 \\
Triple A & ASW 6 & Logged & 1.05 & 0.03 \\
Triple A & ASW 7 & Control & 6.81 & 1.80 \\
Lower FSW & FSW 8 & Control & 0.00 & 0.11 \\
Lower FSW & FSW 9 & Logged & 0.00 & 2.66 \\
L & Logged & 0.00 & 0.50 \\
Lower FSW & FSW 10 & Logged & 0.00 & 0.01 \\
Upper FSW & FSW 11 & Control & NA & 12.0 \\
Upper FSW & FSW 13 & Logged & NA & 3.24 \\
Upper FSW & FSW 14 & Control & NA & 11.6 \\
\hline
\end{tabular}

